



\section{CASTELO DE OUTEIRO UM MARCO NA FRONTEIRA TRANSMONTANA}

ANA MARIA DA COSTA OLIVEIRA

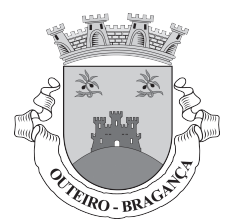


Título: Castelo de Outeiro, um marco na fronteira transmontana

Autoria: Ana Maria da Costa Oliveira

Design gráfico: Helena Lobo Design | www.hldesign.pt

Imagem da capa: Vista oeste do castelo de Outeiro. Foto de César Guedes

Coedição: CITCEM - Centro de Investigação Transdisciplinar Cultura, Espaço e Memória

Via Panorâmica, s/n | 4150-564 Porto | www.citcem.org | citcem@letras.up.pt

Junta de Freguesia de Outeiro, Bragança

Rua do Toural, s/n | 5300-711 Outeiro BGC | juntafreguesia@outeiro-braganca.com | Telm.: 967281526

Depósito legal: 484565/21

ISBN: 978-989-8970-27-5

DOI: https://doi.org/10.21747/9789898970275/cast

Porto, junho de 2021

Paginação, impressão e acabamento: Sersilito-Empresa Gráfica, Lda. | www.sersilito.pt

Este trabalho é financiado por Fundos Nacionais através da FCT - Fundação para a Ciência e a Tecnologia, no âmbito do projeto UIDB/04059/2020. 


\section{SUMÁRIO}

APRESENTAÇÃO

Amélia Polónia

APRESENTAÇÃO

César Garrido

PREFÁCIO

Mário Jorge Barroca

NOTA PRÉVIA

INTRODUÇÃO

1. OUTEIRO NA GEOGRAFIA TRANSMONTANA 33

1.1. Trás-os-Montes, uma região arredada $\quad 35$

1.2. Algumas notas para um enquadramento geográfico 37

$\begin{array}{ll}\text { 1.3. Localização de Outeiro } & 41\end{array}$

2. A OCUPAÇÃO NA REGIÃO DE BRAGANÇA 43

2.1. Antecedentes medievais $\quad 46$

2.2. Um olhar sobre a Idade Média $\quad 50$

3. DA VILA DE OUTEIRO À CONSTRUÇÃO DO CASTELO 59

3.1. As primeiras notícias sobre Outeiro $\quad 61$

3.2. De vila a concelho $\quad 65$

3.2.1. Testemunhos da história de Outeiro $\quad 76$

3.3. Integração de Outeiro nos domínios da diocese de Miranda do Douro 83

4. O CASTELO DE OUTEIRO À LUZ DOS DOCUMENTOS 87

4.1. As referências documentais ao castelo de Outeiro 90

4.1.1. A preocupação com o povoamento da vila e a manutenção do castelo 94

4.1.2. A organização do território em torno do castelo 97

4.1.3. A importância do castelo na defesa da fronteira e da região 99

4.1.4. Os alcaides-mores do castelo de Outeiro $\quad 103$

4.2. Notícias sobre as obras no castelo de Outeiro $\quad 107$

4.3. De um castelo régio a um castelo senhorial $r$

4.4. Intervenções militares em que o castelo de Outeiro esteve envolvido $\quad 112$

5. AS OPÇÕES ARQUITETÓNICAS DO CASTELO DE OUTEIRO 119

5.1. A representação do castelo de Outeiro nos debuxos de Duarte de Armas 121

5.1.1. A função residencial do castelo de Outeiro $\quad 130$

5.2. Abordagem às plantas do castelo de Outeiro produzidas durante o século XVIII 131 
CASTELO DE OUTEIRO, UM MARCO NA FRONTEIRA TRANSMONTANA

5.3. Os vestígios que chegaram até nós

5.4. Fases construtivas do castelo de Outeiro

CONCLUSÃO

FONTES E BIBLIOGRAFIA 
APRESENTAÇÃO

AMÉLIA POLÓNIA 

Uma das missões do CITCEM (Centro de Investigação Transdisciplinar Cultura, Espaço e Memória) é a de promover e publicitar obras científicas de reconhecido mérito, desenvolvidas pelos investigadores do CITCEM, com particular destaque para aquelas que resultam de percursos académicos de qualidade certificada por processos de avaliação científica, cujos contributos se cruzam com linhas temáticas deste Centro de Investigação. O seu plano de publicações disso dá prova.

Este é indiscutivelmente o caso da obra que agora se dá ao prelo. Da autoria de Ana Maria da Costa Oliveira, esta obra é fruto de um trabalho académico desenvolvido sob orientação científica do Professor Doutor Mário Barroca, na Faculdade de Letras da Universidade do Porto. Apresenta-se como mais um contributo de ponta numa área que diretamente interceta investigações prioritárias de um dos Grupos de Investigação do CITCEM: Territórios e Paisagens.

Este Grupo de Investigação foca-se no estudo da paisagem e na organização do território, sobretudo no norte de Portugal, analisando vestígios milenares da presença humana, acumulados por processos de continuidade e mudança. O Grupo inclui especialistas com formação em Arqueologia, História, Arquitetura, Geografia Humana e Física, sendo de natureza interdisciplinar. Ao assumir que a coesão territorial se baseia no conhecimento da identidade cultural de cada região, sendo esta informada pela sua história e património, paisagem construída, artefactos culturais e tendências de povoamento, na sua interação com o desenvolvimento regional, social e económico, é vasta a sua intervenção investigativa, do ponto de vista cronológico, metodológico e territorial.

A presente obra, centrada num estudo sobre o castelo de Outeiro, ao mesmo tempo que se insere nestas linhas programáticas, contribui para o cumprimento de uma outra prioridade do CITCEM: a cooperação com entidades e poderes locais, com os quais promove ações de interesse recíproco. Assim acontece com esta publicação, resultante de uma iniciativa conjunta do CITCEM e da Junta de Freguesia de Outeiro, numa ação que se pretende venha a convergir para a valorização do património cultural da região. Testemunhamos, por isso, o nosso reconhecimento aos responsáveis políticos pela gestão cultural da Junta de Freguesia de Outeiro por incorporarem esta parceria.

O nosso reconhecimento vai também e prioritariamente para a autora, Ana Maria da Costa Oliveira, pelo percurso efetuado, pelos resultados atingidos e pelo seu contributo para as atividades científicas e de transferência do conhecimento do CITCEM.

Amélia Polónia (Coordenadora Científica do CITCEM) 

APRESENTAÇÃO 

A riqueza cultural de um povo mergulha nas profundezas da sua génese e é inexoravelmente moldada pelos vários agentes sociais, económicos, políticos e naturais os quais, no seu conjunto, constituem um espólio indelével da existência de um povo; um marco de relações entre sociedades e, destas, com o meio envolvente.

É destas relações que emana todo o despojo cultural, material e imaterial, que quando preservado, perdura no tempo e se transmite como herança, de geração em geração, podendo assumir-se como elemento potenciador do desenvolvimento das regiões, principalmente das mais desfavorecidas.

Ora, ao longo de séculos da nossa história, a região de Trás-os-Montes esteve sempre longe do pensamento dos decisores, quer por razões de isolamento geográfico, quer pela ausência de políticas de investimento.

Quando, no dia 7 de maio de 2016, num momento carregado de simbolismo, foi inaugurado com pompa e circunstância o Túnel do Marão, queríamos acreditar que Trás-os-Montes ficaria mais ligado ao mundo, pondo fim a este isolamento secular.

No entanto, tal não passou de um sonho que rapidamente se desmoronou como castelos de areia. Cinco anos volvidos, continuamos na mesma situação de interioridade; marcados pelo despovoamento e pelo envelhecimento da população cada vez mais acentuados.

Até ao momento, a atual autoestrada transmontana tem servido mais para esvaziar a região do que para reverter o ciclo de regressão económica social e demográfica, não se tendo revelado como um instrumento capaz de impulsionar a criação de emprego; de dinamizar redes comerciais ou atrair investimentos e pessoas.

Todo o potencial agrícola, natural e cultural de Trás-os-Montes tem sido sistematicamente negligenciado ou sujeito a investimentos esvaziados de eficiência e valia económica.

Milhões de euros foram investidos, de forma indiscriminada, em florestas que foram consumidas pelo fogo, em pomares que morreram prematuramente ou em sumptuosos programas de promoção da região que apenas serviram para os visitantes apreciarem a paisagem e a nossa gastronomia (os vinhos do Douro incluídos), mas que não tiveram, como retorno, qualquer investimento significativo para o desenvolvimento da região e para a criação de emprego, salvo algumas exceções pontuais.

Os testemunhos do nosso passado, continuam a pairar ao sabor da brisa, quais fantasmas saídos de um navio naufragado, e não se vislumbra qualquer vontade política que aponte um caminho para este deprimente esquecimento.

É necessário perceber que a cultura cria riqueza e pode ser explorada em prol do desenvolvimento de um território. Talvez seja esta uma aposta sensata para regiões, como a nossa, profundamente marcadas pela interioridade.

A importância da antiga vila de Outeiro foi reconhecida por D. Manuel I que lhe atribuiu «Foral Novo» a 11 de novembro de 1514. Com este documento, o monarca 
reconhecia os esforços da localidade na construção do país e regulava também a administração, a vida coletiva desta terra, ao mesmo tempo que garantia aos moradores da mesma privilégios, exigindo em contrapartida obrigações e tributos.

Os denominados «Forais Manuelinos» constituíram então um ato reformador de D. Manuel I e substituíram os antigos forais medievais, fomentando uma nova ordem administrativa nos concelhos abrangidos por estes documentos.

A posição geoestratégica da vila de Outeiro de Miranda, reconhecida por diversos monarcas, valeu-lhe ser palco de sucessivos confrontos bélicos.

A base da economia local foi, desde tempos imemoriais, a agricultura, destacando-se a olivicultura. A importância desta atividade para o sustento da população transparece nas Atas das Sessões da Câmara que fazem referência, por exemplo, às vindimas nas diferentes freguesias, à plantação de oliveiras, castanheiros e amoreiras, por serem próprias para o clima, e à criação de animais bovinos e caprinos. Facto curioso é que a Câmara de Outeiro, em reunião de 24 de junho de 1847, suspendeu as reuniões até 1 de agosto, em virtude do muito trabalho que as colheitas implicavam.

Importante é, sem dúvida, a paisagem natural em que Outeiro se insere, tal como o seu património edificado, tendo diferentes monumentos classificados.

As ruínas da velha fortaleza, praticamente reduzida a escombros, invocam diversas campanhas militares e foram recentemente alvo de uma intervenção arqueológica integrada na Operação Castelos a Norte da Direção Regional de Cultura do Norte.

Junto à modesta Casa da Câmara, ergue-se o pelourinho, testemunho do poder local efetivo exercido pelos «Homens Bons», padrão e símbolo da liberdade municipal, marco concelhio e instrumento punitivo.

Merece também referência a igreja de Nossa Senhora da Assunção (Igreja Matriz de Outeiro), de fundação medieval.

Mas, o que mais se destaca, pela sua grandiosidade e beleza artística é, sem dúvida, o Santuário do Divino Santo Cristo de Outeiro, elevado à dignidade de Basílica Menor em 12 de junho de 2014.

Ora, não é difícil concluir que perante um espólio cultural tão significativo a freguesia de Outeiro pudesse caminhar para um processo de desenvolvimento alicerçado na cultura e no ambiente. Houvesse, para isso vontade política e um ordenamento do território capaz de combater as assimetrias regionais e incentivar a criação de riqueza.

Como conclusão, cito uma expressão de António Jorge Nunes, ex-presidente da Câmara Municipal de Bragança: «É preciso que os homens e as mulheres da cultura saibam que o país tem uma dívida histórica por saldar para com o povo transmontano.»

César Garrido (Presidente da Junta de Freguesia de Outeiro, Bragança) 


\section{PREFÁCIO}

MÁRIO JORGE BARROCA 

Nos confins de Trás-os-Montes, mais perto da fronteira com Espanha do que do olhar dos portugueses, erguem-se as ruínas de um castelo que, outrora, teve papel de algum relevo no ordenamento da fronteira do reino: o castelo de Outeiro (ou, como alguma documentação antiga designava, o castelo de Outeiro de Miranda). As suas ruínas passam hoje despercebidas ao olhar de um viajante menos atento. E os parcos muros que dele sobrevivem, despojados de todas as pedras trabalhadas de alguma qualidade ou dimensão, mal deixam adivinhar a forma original que esta estrutura teve. No entanto, o castelo de Outeiro conservou alguma importância e visibilidade até uma fase relativamente tardia da nossa história. Como Ana Maria da Costa Oliveira determina neste seu minucioso estudo, a primeira referência documental a Outeiro de Miranda remonta a 1194, quando a póvoa é mencionada entre os limites de um escambo assinado por D. Sancho I. O regresso de Outeiro à posse da Coroa portuguesa seria um acontecimento do reinado de D. Dinis, o monarca que em 1290 outorgou foral aos moradores de Outeiro. Mas durante mais de século e meio, Outeiro de Miranda foi uma póvoa aberta, isto é, desprovida de estruturas militares. O seu castelo só aparece mencionado, de forma explícita, em 1361. A sua fundação, no reinado de D. Afonso IV, pode ser entendida como um momento terminal da política de reordenamento fronteiriço, encetada por seu pai, D. Dinis, que conduziu muitas terras de fronteira à posse da Coroa e que permitiu a realização de reformas profundas no sistema defensivo do reino, com a plena afirmação do castelo gótico.

As referências documentais ao castelo de Outeiro foram sempre muito parcas e lacunares e, por isso, nem sempre devidamente valorizadas. Os seus testemunhos iconográficos mais antigos são as vistas que Duarte de Armas nos legou no seu Livro das Fortalezas - nas suas duas versões: o Códice de Madrid e o Códice de Lisboa, neste último acompanhadas por uma preciosa planta, cuidadosamente legendada, cheia de pormenores e informações. Mas, ao contrário do que aconteceu com tantos castelos portugueses, que se esvaziaram de sentido e funcionalidade com o triunfo das armas de fogo, a importância de Outeiro chegou até bem mais perto dos nossos dias. Com efeito, nos arquivos militares portugueses conservam-se algumas plantas das estruturas defensivas de Outeiro, levantadas nos meados do século XVIII, que revelam que, nessa altura, a sua estrutura continuava a despertar interesse entre os engenheiros militares portugueses. Poucos anos volvidos, em 1762, no âmbito da Guerra Fantástica, que opôs os dois reinos vizinhos, o castelo voltou a suscitar interesse. Datada desse ano de 1762 conserva-se, na Real Academia de la Historia, em Madrid, uma planta do castelo de Outeiro, levantada por engenheiros militares castelhanos. O conflito, que se iniciou a 9 de maio, e se prolongou até 24 de novembro de 1762 , conduziu, logo no dia 13 de maio, à conquista do castelo de Outeiro. A data ficou tristemente gravada no devir de Outeiro porque coincidiu com o incêndio do seu 
castelo, às mãos das forças castelhanas, e o início da sua ruína. Esvaziado de sentido e de valor estratégico, as suas estruturas conheceram então uma rápida degradação.

Servem estas palavras de introito à monografia que o Leitor tem entre mãos. Ela corresponde ao laborioso trabalho de Ana Maria da Costa Oliveira que, com uma enorme paciência e persistência, foi tecendo uma trama em torno da história deste castelo transmontano. Percorrendo as principais coleções de documentos medievais, pesquisando em revistas, monografias e arquivos, foi coligindo um volume de informações absolutamente extraordinário para um castelo sobre o qual quase nada se conhecia. Este labor prolongou-se durante vários anos de trabalho - certamente mais do que os que deveriam ter sido dedicados se, em circunstâncias normais, a sua Autora tivesse conseguido dedicar a sua atenção apenas à pesquisa que tinha entre mãos. Mas foram as circunstâncias possíveis. E, neste quadro, a persistência evidenciada pela Ana Maria da Costa Oliveira, não deixando cair por terra o seu projeto de investigação, sucessivamente adiado pelas vicissitudes profissionais, ganha outros contornos e outro mérito.

O trabalho que aqui se apresenta corresponde, com ligeiras adaptações (inevitáveis quando se prepara um trabalho académico para uma edição pública de âmbito mais alargado), ao conteúdo da sua dissertação de mestrado, de que tive o prazer de ser orientador. Mas o percurso académico da Ana cruzou-se comigo muito antes de se inscrever no curso de mestrado. Com efeito, a Ana foi minha aluna na Licenciatura de Arqueologia na Faculdade de Letras da Universidade do Porto, entre 1999-2000 e 2002-2003, numa altura em que o plano curricular do curso envolvia um «Seminário de Projecto», no segundo semestre do último ano. Nesse Seminário, a Ana escolheu-me como orientador, e dele resultou uma pequena monografia, entretanto editada em livro, intitulada Duas Torres Senhoriais do Vale do Sousa (Lordelo: Fundação A LORD, 2006). Nela a Ana estudou a Torre dos Alcoforados (Lordelo, Paredes) e a Torre de Vilar (Vilar do Torno e Alentém, Lousada). Alguns anos volvidos, em 20072008 inscreveu-se no curso de Mestrado em Arqueologia, da Faculdade de Letras da Universidade do Porto, e, uma vez mais, veio trabalhar comigo. Depois de cumprida a componente curricular, os afazeres profissionais foram impedindo a conclusão do trabalho, a qual veio a ocorrer apenas em 18 de novembro de 2015 com a defesa da dissertação intitulada Castelo de Outeiro, um marco na fronteira transmontana. Como referimos, a monografia que o Leitor tem agora entre mãos resulta de uma adaptação, minimalista, da sua dissertação de mestrado. Terminada a etapa de mestrado, a Ana decidiu prosseguir estudos, e inscreveu-se em doutoramento. E, como não há duas sem três, voltou a escolher-me como seu orientador. Neste momento está a finalizar a sua tese de doutoramento, que aborda precisamente a organização militar da fronteira transmontana, na qual o castelo de Outeiro é uma peça desse imenso puzzle. 
Os estudos de castelologia portuguesa têm conhecido grande desenvolvimento nas últimas décadas, fruto de um crescente número de intervenções arqueológicas e de investigações, muitas delas conduzidas no âmbito de provas académicas. Mas continuamos a carecer de uma boa série de monografias que estudem, de forma detalhada e devidamente fundamentada, a história dos nossos castelos. Temos, obviamente, algumas honrosas exceções que nos apraz aqui registar, como é o caso da monografia que Saúl António Gomes consagrou ao castelo de Leiria ou do estudo modelar que Isabel Cristina Ferreira Fernandes dedicou ao castelo de Palmela. Mas precisamos de mais. Só com um conjunto numeroso de monografias de castelos poderemos dar um salto qualitativo nos estudos de castelologia e traçar novas sínteses. É nesse contexto que devemos encarar a presente monografia sobre o castelo de Outeiro - um sólido trabalho que ajudou a resgatar do esquecimento este castelo da fronteira transmontana. Um trabalho que urgia editar, para não ficasse esquecido nos repositórios dos trabalhos académicos e fosse revelado à comunidade dos investigadores, dos simples curiosos e, sobretudo, dos habitantes de Outeiro. Para que saibam compreender, valorizar e estimar o seu património: a memória do seu passado, que devem transmitir às gerações futuras.

Uma última palavra para as entidades promotoras desta edição: o CITCEM Centro de Investigação Transdisciplinar Cultura, Espaço e Memória - unidade de investigação sediada na Faculdade de Letras da Universidade do Porto (unidade de I\&D 4059 da FCT), que em boa hora aceitou patrocinar a edição desta obra, que se integra plenamente nos seus desígnios científicos; e a Junta de Freguesia de Outeiro, que cedo compreendeu a importância de que se reveste este estudo para a valorização do património cultural de Outeiro. Não podíamos, por isso, deixar de testemunhar o nosso reconhecimento à Professora Doutora Amélia Polónia, Coordenadora Científica do CITCEM, e ao Senhor César Gustavo Garrido, Presidente da Junta de Freguesia de Outeiro, por terem permitido que este estudo saísse dos prelos. E, claro, felicitar muito particularmente a Ana Maria da Costa Oliveira pelo trabalho que realizou.

Mário Jorge Barroca (Professor Catedrático da Faculdade de Letras da Universidade do Porto, Investigador do CITCEM) 

NOTA PRÉVIA 

A publicação deste livro concretiza, por um lado, um desejo inicial da comunidade de Outeiro (Bragança) em ver o património da sua região divulgado e valorizado, e por outro, uma vontade minha em ver reconhecido um trabalho que pretendeu, desde o primeiro momento, contribuir para o conhecimento da região transmontana.

Esquecido e em ruínas, o castelo de Outeiro foi-me sugerido pelo meu orientador, Professor Doutor Mário Jorge Barroca, como objeto de estudo no âmbito do Mestrado em Arqueologia, na Faculdade de Letras da Universidade do Porto, dando origem a uma tese apresentada à referida instituição em finais de 2015.

No verão de 2016, a autarquia de Outeiro convidou-me para apresentar o estudo à comunidade local que, desde o primeiro momento, incentivou a sua publicação, mostrando-se desejosa por divulgar a sua história e o seu património. Este propósito foi-se adiando, pois, entretanto, dei andamento a um projeto de doutoramento que alargou este estudo inicial a uma abordagem mais vasta, incluindo várias estruturas fortificadas do nordeste transmontano, relacionando-as com a evolução do seu território e da fronteira.

Ainda neste meio-tempo, a região transmontana beneficiou de outras iniciativas que lhe foram acrescentando conhecimento histórico e arqueológico. Estes trabalhos, com realização ou publicação posterior à apresentação da tese de mestrado, serão devidamente integrados e analisados no âmbito do doutoramento, não cabendo nesta publicação a sua referência ou abordagem.

De entre estas iniciativas destacamos apenas a Operação Castelos a Norte, promovida pela Direção Regional de Cultura do Norte (DRCN), que pretende valorizar uma série de castelos transmontanos, onde se integra o castelo de Outeiro. Neste contexto, iniciou em 2019 uma campanha de trabalhos arqueológicos no castelo, complementando assim o processo de conhecimento da estrutura.

A publicação deste livro integra-se assim neste esforço de conhecimento e divulgação do património transmontano, atenuando o desinvestimento que esta região tem sofrido em termos culturais. Esta realização contou com o apoio de diversas pessoas e instituições que congregaram esforços para divulgar um trabalho de investigação que, até ao momento, continua a ser de circulação restrita. Espero que a publicação e a divulgação deste livro possam continuar a constituir uma ferramenta de trabalho útil para futuras investigações, não se limitando apenas a um público estritamente especializado, como acontece atualmente com a dissertação de mestrado, mas antes, procurando alargar horizontes, ficar acessível para a comunidade.

Consciente do caminho percorrido, e dos contributos fundamentais que foram dados para a publicação deste livro, não posso deixar de agradecer a todos os que acompanharam este processo. Em primeiro lugar, e com especial relevo, quero agradecer ao Professor Doutor Mário Jorge Barroca, que tem sido ao longo destes anos não só um verdadeiro mestre - paciente, empenhado, diligente - mas também 
um amigo - compreensivo, disponível e atento - que, sem se impor, está presente. Logicamente, um simples obrigado não traduz tudo quanto lhe devo.

Agradeço também à autarquia de Outeiro, na pessoa do seu presidente, Dr. César Garrido, que sempre se mostrou disponível para nos receber e ajudar em tudo o que solicitamos, demonstrando um claro interesse e empenho na valorização e divulgação do património da sua região, tendo sido o primeiro interessado nesta publicação. Através da Junta de Freguesia de Outeiro, e do seu presidente, colheram-se os apoios indispensáveis para a publicação deste livro.

Agradeço ao Centro de Investigação Transdisciplinar Cultura, Espaço e Memória (CITCEM), promotor e dinamizador desta publicação, a quem propusemos, como investigadora integrada, a sua realização e de quem tivemos a melhor atenção e apoio. No CITCEM, e com o apoio da sua direção, equipa técnica e colegas investigadores, encontrei sempre a abertura desejada e a oportunidade necessária para a concretização de novos projetos de investigação e divulgação de trabalhos realizados. O CITCEM, tem proporcionado novos desafios e oportunidades, que neste caso se traduziram nesta publicação.

Não podia deixar de agradecer também aos responsáveis do Gabinete de Estudos Arqueológicos da Engenharia Militar-Direção de Infraestruturas do Exército, ao Arquivo Nacional Torre do Tombo e à Biblioteca Nacional de Espanha pela cedência das imagens das plantas e vistas do castelo de Outeiro.

Finalmente, um agradecimento muito especial ao César por ser presente de forma incondicional. 
INTRODUÇÃO 



\section{O TEMA}

Os castelos fazem parte da paisagem portuguesa, são elementos identitários que atraem a nossa curiosidade e imaginação. São símbolos de uma história passada, escrita com guerras e protagonizada por reis, cavaleiros e peões. Representam o poder, a glória, a determinação e a resistência de um povo que ousou a independência. Sentinelas de pedra lembram ameaças, mas representam também o último refúgio de populações indefesas.

Como disse José Mattoso, no prefácio da Nova História Militar de Portugal, a sociedade medieval é uma sociedade eminentemente guerreira ${ }^{1}$. O rei, como chefe militar, comandou exércitos de homens, que por razões diversas, travaram batalhas e, pouco a pouco, foram desenhando um território a que chamaram Portugal.

Neste território em construção foram erguidos castelos e desenhadas linhas de fronteira que avançaram para sul, à medida que a Reconquista ganhava terreno aos muçulmanos, e para leste, delimitando um reino que se queria autónomo de Castela.

Foi com o Tratado de Alcañices, em 1297, que se fixaram os limites entre Portugal e Castela. Desde então a monarquia delineou um programa de construção e reforma de fortalezas ao longo da fronteira. A par desse esforço de defesa, a Coroa empenhou-se também na fixação de populações nas zonas raianas, enquadrando-as num aparelho fiscal e administrativo que garantia assim a soberania de Portugal ${ }^{2}$.

Será integrado neste plano de consolidação e proteção fronteiriça, que ganhou contornos evidentes no reinado de D. Dinis, que surgem, na segunda metade do século XIV, as primeiras notícias do castelo de Outeiro. Construído no topo de um outeiro, quase encostado à fronteira nordeste do reino, a fortaleza vigia todo o planalto que liga Vimioso a Bragança.

Região sensível e distante dos centros de poder, a zona de Trás-os-Montes e Alto Douro foi preocupação constante dos monarcas que desenvolveram esforços para dotar o seu território de uma rede de castelos que garantisse a sua independência face aos poderes vizinhos. Assim, no período que medeia entre 1350 e 1450, contavam-se nesta província 27 fortalezas, representando $15,5 \%$ do total dos castelos do reino ${ }^{3}$. Neste número, integra-se o castelo de Outeiro, que completava a primeira linha de defesa da fronteira, que começando em Bragança, passava por Outeiro, Vimioso, Miranda do Douro, Penas Roias, Mogadouro e Freixo de Espada à Cinta.

Apesar das fontes históricas não atribuírem um papel de relevo ao castelo de Outeiro na história militar portuguesa, pensamos que ao longo da sua existência, sobretudo entre a segunda metade do século XIV e 1762, data em que as tropas espanholas queimam o que restava do castelo, terá contribuído para o desenvolvimento e

\footnotetext{
${ }^{1}$ BARATA, TEIXEIRA, dir., 2003: I, 18.

${ }^{2}$ MONTEIRO, 1999: 22.

${ }^{3}$ MONTEIRO, 1999: 26-27.
} 
organização daquela região, como nos mostram os documentos. Preocupados, desde cedo, com o controlo fronteiriço e com a afirmação do poder real, os monarcas da primeira dinastia, sobretudo a partir de D. Sancho I e especialmente com D. Dinis, vão promover uma política centralizadora, recuperando terras a particulares e às instituições eclesiásticas, aumentando progressivamente a área de influência da Coroa numa faixa junto à fronteira, de forma a garantir a segurança do reino. Será precisamente no reinado de $\mathrm{D}$. Dinis que a vila de Outeiro passará para as mãos da Coroa. Nos finais do século XIV, é referida nos documentos como concelho, com seus termos. Nesta altura o castelo já estaria construído, havendo a necessidade da sua manutenção.

As preocupações com o povoamento de Outeiro foram uma constante, motivando inúmeras queixas e pedidos à Coroa, de forma a dinamizar a fixação de população. Este facto demonstra bem a importância de manter aquela região transmontana povoada e defendida.

Como parece claro, o estudo de um castelo pode revelar muito mais do que a sua evolução arquitetónica, as suas opções defensivas ou ofensivas. Ele é um elemento ordenador que diz muito sobre a sociedade medieval e o seu território.

Ao longo da nossa investigação fomos descobrindo uma região. Aprendemos a sua geografia, mergulhamos na sua longa história. Por ela passaram monarcas, senhores e populações anónimas que, sujeitas às políticas de cada época, fizeram parte da construção de um reino. A custo, desenhou-se uma fronteira, pontuada por castelos. Entre eles conta-se o de Outeiro que ainda guarda transformações, inovações e adaptações, que tentaremos sistematizar neste trabalho.

\section{OBJETIVOS DO ESTUDO}

Descobrir o castelo de Outeiro foi uma surpresa.

Esquecido junto à fronteira, a cerca de $30 \mathrm{~km}$ a sudoeste de Bragança, as ruínas do castelo vão resistindo ao tempo e à indiferença. Ausente das rotas de turismo, deslocado das vias principais, permanece silencioso, quase fundido no outeiro que lhe deu o nome.

Periférico numa região já de si arredada, o castelo de Outeiro não foi contemplado com o ambicioso programa de restauro das fortificações, que o Estado Novo desenhou no século XX, procurando legitimação política e apelando à identidade nacional. Testemunha da formação de Portugal manteve assim as cicatrizes de lutas e resistências, de transformações e abandonos. Nas suas parcas ruínas escondem-se séculos de histórias que esperam, pacientemente, ser descobertas. 
Foi a promessa deste esforço de descoberta, que nos motivou a iniciar o estudo deste castelo. Referido em alguns estudos de síntese ${ }^{4}$, faltava trabalhar na sua reconstituição histórica, estudar o castelo no seu todo, integrando-o no espaço de fronteira transmontana, numa região onde era imperativo fixar populações que garantissem a defesa e a soberania dos monarcas portugueses. Faltava situá-lo num tempo histórico, identificar os seus protagonistas e as marcas que deixou na organização da paisagem. Faltava uma análise aprofundada às suas opções arquitetónicas, à sua função como castelo de fronteira transmontana, ao seu protagonismo na história da formação e consolidação do reino. Faltava um olhar mais atento sobre as suas ruínas, que embora maltratadas, ainda escondem evidências e suscitam dúvidas.

Enfim, interessava enquadrar o castelo num território em construção e numa região que se tornou de fronteira com o reino vizinho, descobrindo o seu papel numa conjuntura militar e de defesa, coordenada com outras estruturas fronteiriças que foram determinantes na afirmação da nacionalidade.

\section{METODOLOGIA}

O estudo moderno da castelologia exige critérios científicos que obrigam a intercâmbios entre diferentes especialidades. A par dos registos arquitetónicos e arqueológicos, exige-se também um discurso histórico que dê conta do papel simbólico e prático dos castelos nas mentalidades e quotidiano medievais.

Erguidos no centro ou nas imediações das povoações, os castelos são a garantia do poder numa determinada região. São marcos na paisagem que respeitam uma opção estratégica que se orienta em função do relevo, dos cursos de água, das vias de comunicação e do povoamento. Esta relação deve ser entendida dentro de um contexto histórico, político e social.

Por fim a sua morfologia espelha diferentes evoluções que transformaram e adaptaram o castelo ao longo de diferentes tempos históricos, deixando vestígios e marcas que importa identificar, distinguir e interrogar.

Para a construção do discurso histórico são imprescindíveis as fontes arquivísticas (Chancelarias Régias, Inquirições, documentação avulsa do fundo das Gavetas da Torre do Tombo, etc.) e narrativas (particularmente as crónicas). Nelas encontramos não só informações sobre o castelo, mas também indicadores preciosos sobre o povoamento, a administração do território ou sobre os intervenientes na aplicação do poder político ou da justiça. São eles que nos indicam os proprietários das terras, as suas regalias ou deveres. Dão-nos conta das preocupações das populações e das suas obrigações. Falam-nos de batalhas, de cercos, de exércitos e de inovações

\footnotetext{
${ }^{4} \mathrm{O}$ castelo de Outeiro é referido em trabalhos monográficos e em trabalhos de síntese cujos títulos constam da bibliografia geral. Contudo, destacamos dois estudos: GOMES, 2003 e MONTEIRO, 1999.
} 
arquitetónicas. Neles lemos acordos, alianças e contratos matrimoniais, muitas vezes firmados em castelos, sendo estes garantia do seu cumprimento.

Para além das fontes documentais, também a bibliografia clássica e especializada são fontes inesgotáveis de informação. Ambas contribuem com referências e reflexões que nos ajudam a entender e a enquadrar o objeto do nosso estudo.

Mas o castelo é sobretudo uma realidade física que se insere num meio físico. É necessário pois, entender a paisagem onde ele foi erguido, apreender a sua geografia e saber como esta condicionou a construção da fortaleza. Foram, por isso, estudadas as cartas topográficas, as fotografias aéreas e os ortofotomapas que nos deram uma visão de conjunto sobre o castelo, sobre a região de fronteira onde ele está inserido e sobre o complexo sistema de defesa de que faz parte.

Ainda para compreendermos o castelo de Outeiro e a sua evolução ao longo dos tempos, socorremo-nos da cartografia disponível que, felizmente fixou dados que de outra forma seria difícil descortinar no meio das ruínas atuais.

Primeiro, destacamos os preciosos debuxos de Duarte de Armas, executados por volta de 1509, de que se possuem duas versões: no chamado manuscrito de Lisboa, executado em pergaminho, que se conserva na Torre do Tombo, encontramos duas vistas do castelo de Outeiro e uma planta; no manuscrito de Madrid, executado em papel de linho, que se conserva na Biblioteca Nacional de Espanha, encontramos duas vistas de Outeiro. Este monumental trabalho surgiu da preocupação de D. Manuel I em preparar a fronteira para uma defesa mais eficaz, motivo pelo qual encarregou o seu escudeiro de registar as fortalezas raianas, de forma a estabelecer as medidas necessárias à sua remodelação e modernização. Esta é a fonte orientadora para a compreensão do castelo de Outeiro.

Para além dos desenhos de Duarte de Armas usamos também um conjunto de quatro plantas de data indeterminada, e outras duas com datas de 1753 e de 1762, esta última desenhada na altura em que o castelo foi incendiado pelos espanhóis. Esta documentação, produzida durante a época moderna por militares, e encontrando-se nos seus arquivos, regista a evolução do castelo que resistiu até ao século XVIII.

A preservação e utilização dos castelos durante um dilatado período temporal possibilitaram a criação de documentação variada que registou a sua evolução ao longo dos tempos. Esta realidade é bem patente para as fortificações de fronteira, que sujeitas a uma maior pressão e ameaça, requeriam consequentemente um cuidado suplementar na sua manutenção e requalificação. Por outro lado, os conflitos entre os dois reinos vizinhos suscitaram nos exércitos um cuidado constante de planeamento e preparação dos conflitos, incluindo nos seus planos a observação e registo das fortalezas, as suas opções de defesa e as suas fraquezas.

Estes trabalhos de fortificação e espionagem foram muitas vezes acompanhados pelo registo documental, com desenhos e descrições dos castelos, tornando-se uma 
fonte preciosa de informação nos nossos dias. Foi, de facto, este tipo de cartografia, que nos guiou na observação das ruínas do castelo de Outeiro e na análise da sua evolução ao longo dos séculos.

Dado o seu estado atual de ruína e abandono, onde cresce abundante vegetação, seria difícil compreender os parcos troços de muralha e os escassos alinhamentos de muros sem o apoio da cartografia militar produzida nos últimos séculos. Ela guiou o nosso olhar corroborando as informações documentais que nos ajudaram a desenhar grande parte da planta da fortificação. Mesmo sem escavações pudemos determinar a dimensão do local, a extensão das suas obras e observar os vestígios de superfície. Foi subindo ao outeiro que percebemos a sua posição estratégica, observamos o seu campo de visão e entendemos o sistema defensivo de que faz parte.

O trabalho de campo possibilitou também observar a relação do castelo com o meio onde está inserido, com o povoamento e toda as linhas de comunicação. Nas prospeções percorremos o território para apreendermos a sua geografia, avaliamos as zonas envolventes, que falam do modo de vida e ocupação da região.

Enfim, reunidos todos os dados, foi possível elaborar um cenário político-administrativo que enquadrasse a construção do castelo de Outeiro. Sistematizamos toda a informação a que tivemos acesso elaborando quadros com as principais fases de transformação da fortaleza e dos seus intervenientes. Apresentamos mapas interpretativos, que possibilitam leituras integradas de realidades administrativas, geográficas ou estratégicas. Caracterizamos o castelo, as suas opções construtivas e levantamos hipóteses que poderão contribuir para esclarecer algumas evidências materiais.

Há, pois, um vasto campo de investigação nesta fronteira transmontana à espera de ser descoberto. Os poucos estudos realizados até hoje abordam a ocupação medieval e as suas fortificações de forma parcelar, não permitindo uma análise contínua e fundamentada com dados arqueológicos. A região carece de apostas em investigações de fundo, complementares e abrangentes, que tragam luz a uma época tão pouco aprofundada na investigação arqueológica. 

1

OUTEIRO NA GEOGRAFIA TRANSMONTANA 

A abordagem arqueológica de um território ou região não pode ser dissociada da análise do relevo, da rede hidrográfica, dos solos ou dos recursos naturais que contribuem e condicionam a ocupação e desenvolvimento do espaço, ditando estratégias de povoamento, definindo sistemas agrários e económicos. Os projetos de estudos arqueológicos têm que ser compreendidos dentro do quadro geográfico onde viveram as comunidades.

Conscientes que esse enquadramento geográfico possibilitará um melhor entendimento do nosso estudo, procuraremos fazer primeiro uma abordagem à região de Trás-os-Montes na sua globalidade, realçando a sua posição periférica no território português, fator que determinou um certo tipo de desenvolvimento ao longo do tempo.

Num outro ponto, abordaremos de forma sucinta os principais elementos geográficos da região transmontana, realçando, sempre que necessário e possível, os aspetos que descrevem sobretudo a zona de Outeiro, fazendo referência ao relevo, à rede hidrográfica, ao clima, ao tipo de solo, às culturas e à ocupação humana.

Por fim, debruçar-nos-emos sobre a localização de Outeiro e do seu castelo, refletindo sobre a sua posição junto à fronteira com Castela, a sua proximidade aos rios Sabor e Maçãs, o seu enquadramento no mapa do povoamento vizinho e das principais vias de circulação.

\subsection{TRÁS-OS-MONTES, UMA REGIÃO ARREDADA}

Trás-os-Montes foi sempre uma região periférica, como o seu nome bem caracteriza. É delimitada a sul pelo Douro, a oeste pela barreira montanhosa que se estende do Marão ao Barroso e a norte pelas serras galegas, abrindo-se apenas a nordeste para os planaltos transmontanos que se prolongam para Espanha ${ }^{5}$. Encravada entre montes e vales profundos, Trás-os-Montes é um «quase beco sem saída», como comenta Suzanne Daveau na Geografia de Portugal'.

Também Vergílio Taborda dá conta do isolamento desta região, que se revestiu de características únicas quanto à paisagem e vivência comunitária. Sintetiza o autor que

privado de estradas e caminhos acessíveis, à margem da circulação que anima o litoral do País, de natureza rude, clima excessivo, solo em regra pouco fértil, habitado por uma grei rural que, mantendo uma tradição comunalista vivaz, praticava uma agricultura primitiva e criava os seus gados, bastando-se a si própria, Trás-os-Montes oferece desde cedo uma fisionomia peculiar que o distingue das outras regiões de Portugal?.

\footnotetext{
${ }^{5}$ DAVEAU, 1995: 188.

${ }^{6}$ RIBEIRO, LAUTENSACH, DAVEAU, 1987: 276

7 TABORDA, 1987: 19.
} 
Este arredamento transmontano parece ter acompanhado a região durante grande parte da sua história, pois, durante muito tempo, tanto monarcas como governantes dedicaram mais atenção à zona litoral do país, região onde se concentrava o grosso da população. Era aqui que o comércio florescia e onde o poder central recolhia mais proventos. No nordeste transmontano faltavam os centros urbanos, logo o comércio era pouco expressivo e dinâmico, trazendo rendimentos diminutos.

Apesar de tudo, registaram-se esforços por parte dos monarcas para fixar populações em Trás-os-Montes. Na parte ocidental, onde se assinala um desligamento tardi-hercínico, aproveitado como via de circulação natural e correspondendo a uma zona de veiga com terrenos férteis, onde já tinha sido fundada a cidade de Chaves em época romana, D. Dinis «funda», no século XIII, e na extremidade meridional desta falha, a cidade de Vila Real. Na faixa raiana oriental, e sobretudo depois da fixação das fronteiras com Castela, promoveu-se o desenvolvimento de outros centros urbanos como Bragança e Miranda do Douro, de forma a fixar populações que impulsionassem a atividade económica e garantissem a defesa da fronteira ${ }^{8}$. A par dos centros urbanos mais importantes também se promoveu o povoamento de pequenos concelhos e vilas através da atribuição de forais e da criação de coutos de homiziados, como foi o exemplo de Outeiro.

Mas todos estes esforços não reverteram a situação periférica de Trás-os-Montes que, numa descrição do reino de Portugal, datada de 1416 e escrita pelo arauto do conde de Barcelos, distingue os centros administrativos mais rentáveis dos menos prósperos, incluindo nestes últimos a província de Trás-os-Montes ${ }^{9}$.

Em termos económicos, as regiões transmontanas estiveram sempre muito ligadas e dependentes do comércio com o reino vizinho em detrimento das trocas comerciais com as cidades portuguesas do ocidente. Será só na época contemporânea que Trás-os-Montes vai concretizar a sua ligação e dependência à cidade do Porto ${ }^{10}$. Em meados do século XIX serão construídas três vias que ligam o litoral à região transmontana. Depois das estradas veio a linha férrea que se desenvolverá no eixo natural Vila Real-Chaves, com ligação ao planalto de Bragança. Estas infraestruturas trouxeram um novo dinamismo aos centros urbanos pelos quais passavam, remetendo as vilas periféricas a uma certa estagnação ${ }^{11}$.

Nos últimos anos têm-se desenvolvido esforços para melhorar a questão das acessibilidades. Exemplo disso são as ligações de Bragança ao litoral e a mobilidade pelos planaltos transmontanos, que passando a leste da serra da Estrela, dão acesso às planícies alentejanas. A par desta melhoria rodoviária, houve ainda o desenvol-

\footnotetext{
${ }^{8}$ DAVEAU, 1995: 188.

${ }^{9}$ DAVEAU, 1995: 106.

${ }^{10}$ MENDES, 1985.

${ }^{11}$ DAVEAU, 1995: 189.
} 
vimento da navegabilidade do rio Douro e a ligação aérea a Bragança. Contudo, e excetuando os centros urbanos como Bragança, Chaves ou Vila Real, as restantes cidades e povoações transmontanas sofrem de um problema crónico: o despovoamento, acentuado nos últimos anos pela imigração e o envelhecimento da população. As melhorias implementadas nos últimos séculos na mobilidade e acesso à região transmontana estão longe de mitigar a sua condição de região periférica. $O$ poder central continua vazio de soluções para esta região, quando não decide em seu desfavor. A custo e com poucos recursos, a região vai encontrando o seu lugar no país, graças às suas gentes.

\subsection{ALGUMAS NOTAS PARA UM ENQUADRAMENTO GEOGRÁFICO}

Dada a complexidade e especificidade geomorfológica da região transmontana, e não pretendendo ser este um texto exaustivo e detalhado sobre a especialidade, até porque não é esta a nossa área, optamos por seguir sobretudo o enquadramento geográfico que Francisco de Sande Lemos escreveu na sua obra Povoamento Romano de Trás-os-Montes Oriental, pois, tendo em conta que se trata de um estudo arqueológico, pareceu-nos adequado e de fácil entendimento. Sempre que considerarmos necessário, recorreremos a outros autores da especialidade, dando preferência àqueles que se debruçaram concretamente sobre a região ${ }^{12}$.

Segundo Francisco de Sande Lemos, a região de «Trás-os-Montes insere-se no Maciço Hespérico da Península Ibérica» ${ }^{13}$, também designado como Maciço Antigo, e a sua geomorfologia «só pode ser entendida em função da sua história tectónica antiga e recente. Em consequência dos movimentos orogénicos hercínicos, post-hercínicos e recentes, Trás-os-Montes é um espaço de elevada altitude média, composto por montanhas, planaltos e depressões, um mosaico de fragmentos de uma antiga planície, já marcada pela tectónica anterior» ${ }^{14}$.

Embora o Maciço Hespérico, que ocupa a maior extensão de Portugal e é constituído essencialmente por rochas eruptivas e metassedimentares ${ }^{15}$, se caracterize por uma relativa uniformidade, podem ser individualizadas subunidades que mostram certas particularidades. Assim, a região transmontana faz parte da subunidade Centro Ibérica e, especificamente, da subzona Trás-os-Montes ${ }^{16}$, «onde ocorrem dois maciços de rochas básicas e ultrabásicas, interpretados como sendo complexos ofiolíticos» ${ }^{17}$.

\footnotetext{
${ }^{12}$ As obras consultadas para este capítulo estão descritas na bibliografia. Como base, e para além do trabalho de Francisco de Sande Lemos, usaremos sobretudo o trabalho de Vergílio Taborda.

${ }^{13}$ LEMOS, 1993: I, 88.

${ }^{14}$ LEMOS, 1993: I, 88.

${ }^{15}$ ALMEIDA et al., 2000: 3.

${ }^{16}$ Carta Geológica de Portugal, 1992.

${ }^{17}$ ALMEIDA et al., 2000: 4.
} 
Ora, a povoação de Outeiro, e segundo a Carta Geológica de Portugal ${ }^{18}$, insere-se nos Maciços de Morais e Bragança, onde predominam os xistos e grauvaques. De forma mais pormenorizada, Francisco de Sande Lemos dá conta que no «arco que se estende de Outeiro a Meirinhos (Mogadouro), a litologia é bastante complexa, ocorrendo diversos tipos de rochas: gneisses, metavulcanitos ácidos e básicos, xistos verdes, formações vulcano-siliciosas, quartzitos, bem como xisto-grauvaques culminantes (Carta Geológica Esquemática 1:200 000)» ${ }^{19}$.

Relativamente ao relevo transmontano, e no que se refere essencialmente ao Alto Trás-os-Montes, tomando a designação de Vergílio Taborda ${ }^{20}$ para a região onde se insere o concelho de Bragança, podemos dizer que é formado por planaltos com uma quota média de $700 \mathrm{~m}$, pontuados por elevações e cortados por linhas de água que formam vales profundos.

Assim, temos a sul de Bragança e de Outeiro a serra de Mogadouro (993 m) e a serra de Bornes $(1174 \mathrm{~m})$, mais a sudoeste a serra da Nogueira $(1318 \mathrm{~m})$ e a norte, fazendo fronteira com Espanha, a serra da Coroa (1273 m) e a de Montezinho (1416 m). Para além das serras que envolvem a região de Bragança, e como resultado dos movimentos tectónicos, há ainda relevos formados por cristas quartzíticas que, por causa da sua dureza, resistiram à erosão ${ }^{21}$. Esta extensa zona de planaltos é rasgada pelo rio Sabor, curso de água mais importante, pelo rio Maçãs, que delimita a fronteira oriental de Portugal, e pelo rio Angueira, «que abrem cortes estreitos e profundos» nos solos xistosos e quartzíticos silúricos, formando meandros ${ }^{22}$.

Mas esta diversidade complexa não se espelha apenas na sua geomorfologia. Ela estende-se também ao clima, que como escreveu Vergílio Taborda, é «excessivo». Daí que se tenha dividido a província em duas regiões, hoje muito faladas em termos promocionais: a Terra Fria, que corresponde grosso modo ao Alto Trás-os-Montes de Vergílio Taborda ${ }^{23}$ e que ocupa a parte norte da província, e a Terra Quente, região mais a sul que se prolonga até ao rio Douro. Esta dualidade verificada no território transmontano deriva da sua "confluência entre os ecossistemas mediterrânicos e atlânticos» ${ }^{24}$. Contudo, acrescenta Francisco de Sande Lemos,

\footnotetext{
${ }^{18}$ Carta Geológica de Portugal, 1992.

${ }^{19}$ LEMOS, 1993: I, 131.

${ }^{20}$ A designação de Alto Trás-os-Montes, alternativa a Terra Fria, é escolhida por Vergílio Taborda que argumenta: «A designação de terra fria, usada principalmente pelos agrónomos, não se poderia aplicar com propriedade ao conjunto da região, a qual engloba a sul alguns territórios considerados comummente como terra quente, além de que, na linguagem popular, tem sempre um significado restrito, local, referido aos contrastes de relevo, exposição, e, consequentemente, de clima e vida vegetal, às vezes no espaço limitado dum concelho e até duma freguesia.» TABORDA, 1987: 21.

${ }^{21}$ LEMOS, 1993: I, 88.

22 TABORDA, 1987: 48-50.

23 TABORDA, 1987.

${ }^{24}$ LEMOS, 1993: I, 91.
} 
se é verdade que confluem no Norte de Portugal paisagens influenciadas pelos dois sistemas, é um facto incontestável que, em rigor, o clima de Trás-os-Montes, como o do Minho, como, de resto, o de parte da Galiza, apresenta um perfil claramente mediterrânico, ou seja chuvas irregulares, distribuídas pelo Outono, Inverno, e Primavera, e Verões secos, por vezes estiagens prolongadas ${ }^{25}$.

A estas duas regiões geográficas, Terra Fria e Terra Quente, Francisco de Sande Lemos acrescentou uma outra: a Terra de Miranda, que subtraiu à Terra Fria que diz abranger apenas «os concelhos de Vinhais e Bragança, salvo a zona de Outeiro, que se integra na Terra de Miranda» ${ }^{26}$. $\mathrm{O}$ autor, baseado em trabalhos de outros geógrafos, reconhece na Terra de Miranda, designação medieval de um território, características geográficas homogéneas e delimita a sua área que a norte

corresponde à fronteira luso-espanhola, a qual não se apoia em acidentes geomorfológicos assinaláveis, de tal modo que foi, ao longo das épocas medieval e moderna, um corredor de passagem natural para os exércitos leoneses e castelhanos. O limite leste é traçado pelo rio Douro. A sul, a Terra de Miranda termina contra os relevos formados pelas áridas serras da Navalheira (sudoeste) e do Mazouco (sudeste). A oeste, finda no profundo vale do rio Sabor ${ }^{27}$.

Dentro da Terra de Miranda o autor distingue ainda «o planalto de Argoselo-Outeiro, paralelo ao de Algoso-Vimioso» que diz ser «delimitado pelos rios Sabor e Angueira, terminando em cunha a sul, e confrontando a norte com o altiplano que sobe progressivamente até Deilão (altitude 958 metros); [...] na sua metade norte distingue-se a majestosa cumeada onde se conservam as ruínas do Castelo Medieval do Outeiro» ${ }^{28}$.

Nesta zona de planaltos, as terras acima dos $700 \mathrm{~m}$ caracterizam-se por verões quentes e invernos muito frios enquanto que, nos cabeços e encostas dos rios Sabor e Douro, o verão é muito quente e o inverno frio ${ }^{29}$.

A área da Terra de Miranda é revestida essencialmente por litossolos, tratando-se de solos pouco evoluídos, de pouca profundidade $(10 / 20 \mathrm{~cm})$ e com material pedregoso incorporado. Estão frequentemente associados a afloramentos rochosos e são pobres em matéria orgânica, por isso, com pouca apetência agrícola. A par destes solos há ainda manchas de luvissolos, mais profundos $(60 / 120 \mathrm{~cm})$, com permeabi-

\footnotetext{
${ }^{25}$ LEMOS, 1993: I, 92.

${ }^{26}$ LEMOS, 1993: I, 110.

${ }^{27}$ LEMOS, 1993: I, 130.

${ }^{28}$ LEMOS, 1993: I, 141.

${ }^{29}$ LEMOS, 1993: I, 134.
} 
lidade razoável e fertilização natural, o que os torna mais aptos para a agricultura. Devido aos processos de erosão, estes solos encontram-se sobretudo nos vales, beneficiando da acumulação das terras que são arrastadas pelas águas das encostas quase despidas de revestimento vegetal.

Para além das limitações do solo e do clima, de temperaturas irregulares, Vergílio Taborda escreve que a agricultura se mantinha, no início do século passado, muito atrasada $^{30}$. Acrescenta que Trás-os-Montes é «um país de culturas pobres, onde os cereais de grande rendimento, como o trigo, têm um lugar secundário. O homem não pôde remediar a pobreza natural do solo, mantendo-se fiel a um sistema cultural rotineiro que ignora as adubações cuidadas. $\mathrm{O}$ agricultor transmontano explora a terra quase como ela se lhe oferece» ${ }^{31}$.

A cultura da Terra Fria era essencialmente o centeio, cereal menos exigente e mais resistente às variações climáticas. A par deste cereal, cultivava-se algum trigo, produtos hortícolas, essencialmente para o sustento das famílias, e fruta.

Como culturas «tradicionais», e além do centeio, cultivava-se também a vinha, sobretudo nas encostas com boa exposição solar, e o linho, escolhendo para este os terrenos mais férteis junto à água. Estas duas culturas são referidas em textos de época romana e documentos medievais.

Por último, e no que se refere ainda aos produtos da terra, há que destacar os soutos de castanheiros que, a par do olival, se tornaram hoje cartão de visita das terras transmontanas.

Para além da agricultura, a floresta e a criação de gado eram atividades de grande importância. Tanto uma como a outra aproveitavam os solos menos aptos para a agricultura, que como já vimos ocupavam a maior parte da área transmontana. $\mathrm{O}$ animal de excelência dos planaltos era o boi, fonte de riqueza e força de trabalho. Depois os rebanhos, sobretudo de carneiros. A terminar, a caça, complemento à alimentação e economia familiar, também ela referida em documentos medievais.

Finalmente, uma nota sobre a divisão da propriedade e a ocupação humana, sobretudo no que diz respeito à região em estudo. Excetuando a cidade de Bragança, todas as outras povoações são de dimensão reduzida. As vilas e aldeias formam um povoamento de «tipo aglomerado» onde as casas se agrupam «em estreita solidariedade formando núcleos compactos, massas mais ou menos coerentes, aldeias e lugares. A quinta, o grupo de habitações disperso no meio das culturas quase não existe» ${ }^{32}$. Este povoamento concentrado e rarefeito procura, como refere Vergílio Taborda, a solidariedade comunitária nas tarefas agrárias, tentando vencer o isolamento, as

\footnotetext{
30 TABORDA, 1987: 76.

31 TABORDA, 1987: 77.

${ }^{32}$ TABORDA, 1987: 126.
} 
agruras do clima e a pobreza dos solos. Dispersos, dificilmente conseguiriam sobreviver nestas condições.

Nos planaltos transmontanos predomina uma paisagem de terrenos cultivados, ladeados por sebes vivas de arvoredo, ocupando as zonas mais férteis e junto às povoações. Aqui é a propriedade individual que domina, retalhando o solo por pequenos proprietários. Esta divisão física do terreno com sebes ou muros de pedra seca foi crescendo ao longo do tempo, individualizando hortas, lameiros e prédios. Fora do perímetro das povoações, sobretudo nos vastos planaltos, nas encostas e nos terrenos incultos, a propriedade é coletiva, com áreas abertas onde se levam os rebanhos ou se recolhe lenha e mato para os animais ${ }^{33}$.

\subsection{LOCALIZAÇÃO DE OUTEIRO}

Outeiro é uma das 38 freguesias do concelho de Bragança, situando-se a cerca de $30 \mathrm{~km}$ a sudeste desta cidade. Localiza-se, como já se referiu anteriormente, na peneplanície de Argozelo-Outeiro a uma altitude média de $710 \mathrm{~m}$. O seu castelo foi construído a cerca de $600 \mathrm{~m}$ a este da povoação, coroando um outeiro com cerca de $807 \mathrm{~m}$ de altitude. As coordenadas geográficas da fortificação são: 41.682972 / -6.391802 (Mapa 1).

O acesso à povoação é feito pela EN 218 que liga Bragança a Outeiro e segue para Vimioso, que fica a sudeste da freguesia. Entrados na povoação, toma-se a direção de Pinelo pela EN 218-2 e, a cerca de 100 m e à saída da povoação, vira-se à esquerda num estradão em terra batida, ao lado do lar de idosos. Seguindo o estradão, encosta acima, encontramos as ruínas do castelo.

A povoação de Outeiro desenvolveu-se a poente do monte, numa chã atravessada pela ribeira da Vila, que contorna o monte a norte e vai desaguar no rio Maçãs. Este rio corre a nascente da povoação, servindo de limite fronteiriço entre Portugal e Espanha quase até às imediações da vila. Do lado oposto, portanto, a poente, o planalto é rasgado pelo rio Sabor, que nesta zona apresenta encostas abruptas.

Visto do castelo, Outeiro tem claramente dois núcleos habitacionais: um que se desenvolve junto da igreja matriz, cuja padroeira é Nossa Senhora da Assunção; e outro que se situa junto da igreja de Santo Cristo. Entre os dois polos passa a ribeira da Vila.

\footnotetext{
33 TABORDA, 1987: 103.
} 


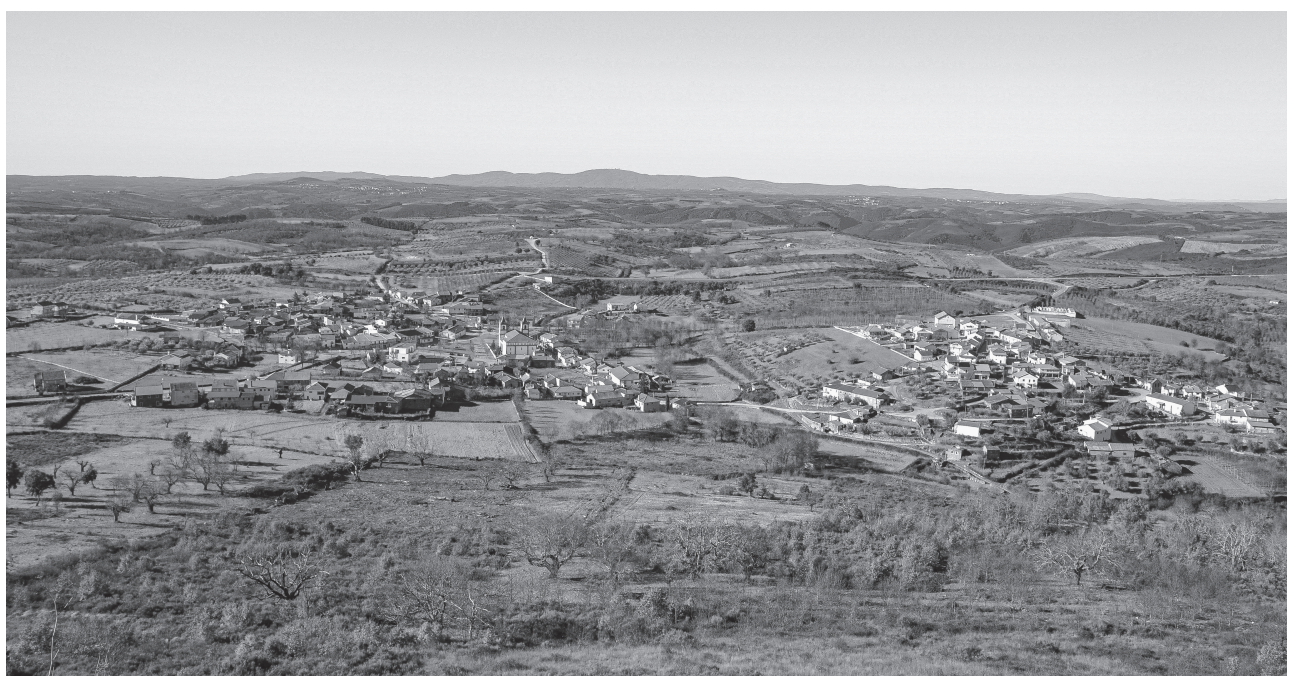

Fig. 1. Povoação de Outeiro dividida em dois núcleos ${ }^{34}$

Tendo recebido foral de D. Manuel em 1514, Outeiro foi sede de concelho, extinto em 31 de dezembro de 1853. Hoje a freguesia totaliza uma área de quase $41000 \mathrm{~km}^{2}$ e tem anexa a aldeia de Paradinha de Outeiro. Com uma população envelhecida, contava, até há poucos anos, com pouco mais de 300 habitantes, um terço dos residentes de meados do século passado ${ }^{35}$. Sem oportunidades de trabalho e com uma economia centrada na agricultura, a população mais jovem foi procurando soluções nas cidades da região, nos grandes centros urbanos do litoral ou no estrangeiro.

A riqueza transmontana centra-se assim no seu património cultural e natural, exigindo do poder municipal políticas de proteção e valorização destas valências. Reconhecendo o valor paisagístico desta zona transmontana, foram definidas no Plano Director Municipal de Bragança, uma Zona de Proteção Especial (ZPE) dos rios Sabor e Maçãs, bem como um Sítio de Importância Comunitária (SIC) dos mesmos rios. Foram ainda criadas faixas de proteção de espaços naturais, que incluem os maciços rochosos, do qual faz parte o outeiro do castelo, procurando a salvaguarda dos valores paisagísticos, através da proibição de construções definitivas ${ }^{36}$.

A estas medidas de proteção dos espaços naturais, devem ser adicionadas políticas de salvaguarda patrimonial, quer histórico quer arqueológico que abarque todo o concelho, numa primeira fase, e se estenda progressivamente a toda a região transmontana.

\footnotetext{
${ }^{34}$ As fotografias constantes na publicação são da autoria de Ana Maria da Costa Oliveira e de César Guedes.

${ }^{35}$ Informações retiradas do sítio da internet da Câmara Municipal de Bragança: http://www.cm-braganca.pt, no dia 2 de julho de 2015.

${ }^{36}$ Plano Director Municipal de Bragança, 2009.
} 
2

$$
\begin{array}{r}
\text { A OCUPAÇÃO NA } \\
\text { REGIẪO DE BRAGANÇA }
\end{array}
$$



Neste capítulo propomo-nos lançar um breve olhar sobre a história da ocupação humana no concelho de Bragança, apontando os elementos mais relevantes sobre o habitat da região, contextualizando-os, sempre que necessário, sob os pontos de vista político e administrativo e valorizando sobretudo os contextos que definam o nosso objeto de estudo: o castelo de Outeiro e o seu território.

Este enquadramento "histórico», chamemos-lhe assim, teve como base alguns estudos sobre a região e algumas, poucas, conclusões de trabalhos arqueológicos realizados essencialmente no perímetro da cidade de Bragança, nomeadamente no âmbito do Programa Polis. A ausência de trabalhos arqueológicos, concretamente de prospeções sistemáticas, levantamentos topográficos e escavações, impede um conhecimento mais esclarecido e fundamentado sobre a ocupação bragançana. Resta-nos então, os trabalhos de recolha e pesquisa de algumas personalidades dos séculos XIX e $\mathrm{XX}^{37}$, e os estudos de investigadores atuais que vão contribuindo de forma decisiva para o esclarecimento do povoamento da região ${ }^{38}$.

Num primeiro ponto começaremos pelos antecedentes medievais da região, referindo alguns povoados fortificados, sobretudo datáveis de finais da Idade do Ferro que, pela sua importância estratégica, continuaram a ser ocupados em épocas posteriores, inclusive, durante a Idade Média.

Ainda neste ponto será abordada a ocupação romana e a importância do seu legado na organização territorial, nomeadamente no que se refere à exploração económica da terra e às vias de circulação.

Num segundo momento lançaremos um olhar sobre a Idade Média. Tarefa complicada dada a grande diacronia que medeia entre o fim do Império Romano e a plena Idade Média, época onde se enquadra o nosso castelo. Mas como não pretendemos fazer aqui uma resenha histórica detalhada, concentrar-nos-emos nos aspetos mais relevantes para o nosso estudo. Assim, definiremos um breve enquadramento político-administrativo da região bragançana, apontando as principais medidas para a integração deste território na Coroa portuguesa. Mencionaremos os principais problemas relacionados com o povoamento e a defesa, bem como as medidas mais importantes para a sua resolução. Por fim, procuraremos, através dos principais vestígios arquitetónicos e arqueológicos, obter uma imagem sobre a organização territorial de Bragança.

\footnotetext{
${ }^{37}$ Destes trabalhos destacamos a obra monumental do Abade de Baçal (ALVES, 2000) e os Apontamentos Arqueológicos de Albino dos Santos Pereira Lopo (LOPO, 1987).

${ }^{38}$ Dos trabalhos de investigação mais recentes e desenvolvidos por especialistas destacamos sobretudo a tese de Francisco de Sande Lemos (LEMOS, 1993) e os artigos sobre os trabalhos arqueológicos realizados na cidade de Bragança publicados em Bragança, um olhar sobre a História. Consultamos ainda a base de dados Portal do Arqueólogo, onde estão registados todos os sítios e vestígios da região de Bragança: http://arqueologia.patrimoniocultural.pt.
} 


\subsection{ANTECEDENTES MEDIEVAIS}

No território de Bragança a distribuição dos sítios proto-históricos, romanos e medievais são conhecidos graças aos trabalhos de entusiastas como o Abade de Baçal e Albino dos Santos Pereira Lopo, verdadeiros precursores do árduo trabalho de registo e descrição dos sítios com interesse arqueológico do concelho. De forma incansável foram descrevendo, desenhando e recolhendo espólio que hoje serve de base a outros trabalhos, melhorados com novas metodologias, resultando em estudos mais fundamentados e completos ${ }^{39}$.

Assim, e tomando como referência os estudos anteriores, procuraremos neste ponto, retroceder a nossa análise até à Idade do Ferro, altura em que nos parece começar a desenhar-se a matriz de ocupação deste espaço, definindo-se zonas preferenciais de habitat e de exploração do território. Alguns destes povoados proto-históricos, tornar-se-ão importantes polos de fixação em época romana, traduzindo uma estratégia de exploração territorial que acabará por determinar importantes eixos de circulação e fixação em épocas posteriores.

$\mathrm{Na}$ área atualmente ocupada pelo concelho de Bragança, dominavam os Zoelas, povo referido por Plínio e cujo centro de poder se localizava na zona de Bragança, possivelmente em Castro de Avelãs, num local chamado Torre Velha ${ }^{40}$. O seu território seria delimitado pelas serras da Coroa e Nogueira, a sul pela serra de Bornes, a oriente pelos rios Douro e Esla, e a norte pelas serras da Sanábria. Parece-nos claro que o planalto onde se desenvolveu Outeiro pertencia aos domínios deste povo. A existência dos Zoelas e do seu território encontra-se comprovada, sobretudo, através de achados epigráficos, entre os quais se destaca a Tabula de Astorga, onde se firmou um pacto de hospitalidade entre famílias Zoelas e romanos.

Nesta região bragançana, Francisco de Sande Lemos contabilizou 48 povoados da Idade do Ferro, notando que apenas 11 apresentavam indícios de romanização ${ }^{41}$. Os povoados desenvolveram-se sobretudo na depressão de Bragança, onde os solos têm boa apetência agrícola, e ao longo dos rios Sabor e Maçãs, nas orlas dos planaltos e nas cristas quartzíticas, que ofereciam excelentes condições estratégicas ${ }^{42}$. Segundo o autor, estes habitats apresentam dimensões modestas e os seus sistemas defensivos são simples, constituindo-se por uma única linha de muralha e, por vezes, por um

\footnotetext{
${ }^{39}$ Baseando-se nestes e noutros trabalhos precursores, Francisco de Sande Lemos faz, na sua obra intitulada Povoamento Romano de Trás-os-Montes Oriental, uma incursão sobre a ocupação transmontana, catalogando uma série de sítios que vão da Proto-história até à Idade Média. Por ser um trabalho de síntese e com uma abrangência tão larga, será inevitável seguir os seus passos para caracterizarmos a ocupação humana da nossa área de estudo.

${ }^{40}$ Em 2012 arrancou o projeto Povo Zoela coordenado pelo Prof. Doutor Pedro Carvalho, da Faculdade de Letras da Universidade de Coimbra e pela Dr. ${ }^{a}$ Clara André, arqueóloga da Câmara Municipal de Bragança, com escavações arqueológicas no sítio da Torre Velha. Embora ainda não seja conclusivo, existe uma forte possibilidade do local ser, de facto, o centro administrativo dos Zoelas.

${ }^{41}$ LEMOS, 1993: II, 33.

${ }^{42}$ LEMOS, 1993: I, 166-167.
} 
ou mais fossos. Uma grande maioria dos povoados albergava um número reduzido de famílias que exploravam as áreas em volta, dedicando-se à agricultura nas zonas onde os solos o permitiam, à pastorícia e à caça.

No planalto de Argozelo-Outeiro, os povoados desenvolveram-se sobretudo nas margens dos rios Sabor e Maçãs. Nas imediações de Outeiro e nas margens do Sabor, estão cartografados quatro povoados da Idade do Ferro. Dois na margem direita do rio: Castro Mau e Castrilhão de Coelhoso, este último situado num esporão junto a uma ribeira afluente do Sabor; e outros dois na margem esquerda do mesmo rio: Castro Mouro de Outeiro e S. Bartolomeu de Argozelo. Na margem direita do rio Maçãs e a montante de Outeiro, fica o povoado do Barrocal de Quintanilha e a jusante da vila encontra-se o povoado do Castelo do Serro Grande. Por fim, e sem confirmação arqueológica, os autores atrás referidos, apontam para a possibilidade de o outeiro de Outeiro ter sido um «castro», com ocupação anterior ao castelo, dada a sua posição estratégica ${ }^{43}$.

Para além destes sítios, e também com cronologias da Idade do Ferro, a base de dados do Portal do Arqueólogo aponta outros povoados fortificados nas imediações de Outeiro, nomeadamente em Parada/Faílde: Fraga do Cavaleiro e Senhora da Conceição, ambos com ocupação romana; em Grijó de Parada: Castelinho e Penedo, este último com ocupação romana; e em Rio Frio/Milhão: Castelo dos Mouros, Castragosa, Terronha e Vale dos Prados, este último com ocupação romana ${ }^{44}$.

Será durante o século I a. C. que o processo de romanização em Trás-os-Montes começa a transformar o território. Toda a região de Bragança, incluindo Outeiro, passa a pertencer ao Conventus Asturum, divisão jurídica criada entre os governos de Augusto e Cláudio.

A economia, outrora vocacionada para a autossuficiência, cresce produzindo excedentes e impulsionando um novo mercado onde circula a moeda. A produção agropecuária e a mineração sentem um novo incremento alimentando esse mercado mais vasto. A par das transformações económicas vai-se consolidando uma nova ordem política, social e religiosa ${ }^{45}$.

O Império Romano trouxe uma nova conceção do espaço onde as «fronteiras» se expandem e a mobilidade é constante. Este movimento era suportado por uma rede viária estruturada que servia os interesses do Império.

Na zona de Bragança a via principal era a XVII do itinerário de Antonino, que «ligava Bracara Augusta (Braga) a Asturica Augusta (Astorga) por Aquae Flaviae (Chaves), no sentido oeste-este, num total de 247 milhas $(370 \mathrm{~km}$, em números

\footnotetext{
${ }^{43}$ LEMOS, 1993: II, 70-72, 113-115, 121-122, 416-418.

${ }^{44}$ Dados retirados do Portal do Arqueólogo: http://arqueologia.patrimoniocultural.pt.

${ }^{45}$ ANDRÉ, 2008: 47.
} 
redondos) ${ }^{46}$. Esta via tinha dois traçados entre Chaves e Castro de Avelãs. O que passava mais a norte era o mais antigo, sendo atribuído à época de Augusto. De Castro de Avelãs a via seguia num único troço, passando pela depressão de Bragança, por Gimonde, Babe, Palácios, até ao rio Maçãs, continuando o seu trajeto através do atual território espanhol. A via XVII foi assinalada por miliários cuja descoberta ajudou os investigadores a desenhar o seu percurso. Para além dos miliários foram também sinalizados locais que serviram de apoio aos viajantes, como mansiones, mutationes e stationes.

Da via XVII partiriam itinerários secundários, como o que derivava em Babe e descia pelo planalto de Argozelo-Outeiro. Esta rota, que em parte poderá corresponder ao traçado da EN 218, tinha sobretudo uma importância económica, pois dava acesso às minas de estanho de Argozelo.

O povoamento na região de Bragança e durante a época romana desenvolveu-se ao longo da via XVII, concentrando-se na zona em volta de Castro de Avelãs e na margem direita do rio Sabor. Alguns dos antigos povoados fortificados da Idade do Ferro continuaram a ser ocupados, mas outros foram abandonados.

Como exemplo de povoados ocupados nesta altura, temos o de S. Bartolomeu de Argozelo, na margem esquerda do rio Sabor, e de Castrilhão de Coelhoso, na margem direita do mesmo rio. A sudoeste deste último "castro», existiria o Castro de Coelhoso, um povoado romano aberto, com boas condições agrícolas e junto a importantes jazidas de estanho. Ainda no mesmo planalto e perto de Argozelo há notícias da existência de minas romanas, também de estanho, num local chamado Bocarra de Argozelo. Por último, e a norte de Outeiro, na margem direita do rio Maçãs, o povoado do Barrocal de Quintanilha também teve ocupação romana. Tanto este último exemplo como os dois povoados nas margens do rio Sabor parecem ter servido propósitos estratégicos de controlo das vias de circulação. S. Bartolomeu de Argozelo e Castrilhão de Coelhoso controlavam a passagem sobre o rio Sabor, que levava a Coelhoso onde se encontravam as minas. Por seu lado, o povoado do Barrocal de Quintanilha, localizava-se numa zona de passagem sobre o rio Maçãs que dava acesso à zona de Zamora. Seria também possível que controlasse a passagem da estrada secundária que, vinda de Argozelo, entroncava na via XVII, no Sagrado de Babe, onde terá existido uma statio ${ }^{47}$.

Ainda segundo a base de dados do Portal do Arqueólogo, e para além dos povoados fortificados romanizados que já referimos acima, registam-se ainda como possíveis habitats romanos a Torre de Medorro, em Grijó de Parada; Ferradoza e

\footnotetext{
${ }^{46}$ ANDRÉ, 2008: 47.

${ }^{47}$ LEMOS, 1993: II, 41-43, 70-73, 121-122, 417-418.
} 
Muradelhas, em Parada/Faílde e foi localizada uma estela no lugar chamado Carva, em Outeiro ${ }^{48}$.

Apesar dos escassos trabalhos de escavação desenvolvidos nos locais já identificados com ocupação romana, devemos destacar os que foram realizados na cidade de Bragança no âmbito do Programa Polis, que decorreram entre 2002 e 2004, e os que foram realizados pelo Gabinete Técnico Local que foi criado para intervir de forma preventiva na área urbana da cidade. O programa de obras alargou-se a uma boa parte da zona histórica da cidade, incluindo a cidadela.

No que diz respeito a estas intervenções e concretamente sobre o período romano «as investigações realizadas confirmam a presença, em vários pontos da cidade, da Cidadela à Praça Camões, de muros e materiais romanos datados entre o século I e o século III d. C. ${ }^{49}$. Os vestígios encontrados mostram uma ocupação de "certa importância no panorama do mundo romano do Noroeste peninsular» ${ }^{50}$. Para além da importância dos vestígios materiais parece haver uma continuidade de ocupação. E embora ainda não seja possível esclarecer com certeza a natureza dessa ocupação, deve-se realçar a relevância estratégica de Bragança, situada junto à via que liga Braga a Astorga, sugerindo uma posição de controlo daquela região. Daí a hipótese posta pelos investigadores de estarmos perante «um acampamento militar, que, à semelhança do que aconteceu em locais bem próximos na vizinha Espanha, tenha estado na origem de um povoado que se cristalizou na Bragança dos nossos tempos» ${ }^{51}$.

Numa outra área do concelho, e numa zona de extrema importância para a compreensão da ocupação romana e proto-histórica da região, iniciou-se em 2012 um projeto de investigação designado como Povo Zoela promovido pela Câmara Municipal de Bragança e pela Faculdade de Letras da Universidade de Coimbra. As escavações foram realizadas na Torre Velha de Castro de Avelãs, local indicado como sede da civitas Zoelarum ${ }^{52}$. Este local já havia sido intervencionado em 1887 por Henrique Pinheiro, que descobriu vestígios de construções com colunatas e as ruínas de um templo medieval com necrópole. De 1887 a 2012 o local não voltou a ser escavado ${ }^{53}$.

Nas escavações iniciadas em 2012, confirmou-se que Torre Velha de Castro de Avelãs teve uma ocupação que se estendeu ao longo de mil anos ${ }^{54}$. São abundantes os vestígios romanos que se juntam ao conjunto epigráfico já conhecido daquela zona.

\footnotetext{
${ }^{48}$ Dados retirados do Portal do Arqueólogo: http://arqueologia.patrimoniocultural.pt.

${ }^{49}$ LIMA, ARGÜELLO MENÉNDEZ, coord., 2004: 159.

${ }^{50}$ LIMA, ARGÜELLO MENÉNDEZ, coord., 2004: 160.

${ }^{51}$ LIMA, ARGÜELLO MENÉNDEZ, coord., 2004: 21.

${ }^{52}$ Informações retiradas da página online do projeto Povo Zoela em: http://projetozoelas.wix.com.

${ }^{53}$ LEMOS, 1993: I, 44-45.

${ }^{54}$ Segundo o Prof. Doutor Pedro Carvalho, coordenador técnico científico do projeto, para além da ocupação romana, houve também uma ocupação alto-mediévica que já tinha sido detetada nas escavações do século XIX e que abordaremos melhor no ponto seguinte.
} 
Segundo os investigadores ${ }^{55}$, os dados até agora disponíveis oferecem fortes indícios de o local ter sido, de facto, a capital da civitas Zoelarum.

\subsection{UM OLHAR SOBRE A IDADE MÉDIA}

Como já referimos na introdução a este capítulo, o olhar que pretendemos lançar sobre a Idade Média da região vai encontrar alguns obstáculos, devido ao longo período temporal que esta fase histórica abrange. Deste modo, e de forma a contextualizar a nossa visão, faremos primeiro uma abordagem baseada sobretudo nos vestígios materiais conhecidos, enquadrando-os depois num cenário político-administrativo.

Se encontramos muitas dúvidas sobre o tipo de ocupação que Bragança teve em épocas anteriores, para o período alto-mediévico parecem manter-se as interrogações.

O Parochiale Suevorum faz referência a um pagus chamado Brigantia que integraria a diocese de Braga no século VI. A localização desta paróquia parece dividir os investigadores, que colocam a hipótese de ela se ter situado em Torre Velha, Castro de Avelãs, ou no local onde se edificou a atual cidade de Bragança ${ }^{56}$.

Os trabalhos arqueológicos realizados nos dois sítios trouxeram para a discussão alguns dados relevantes. Assim, e no que diz respeito a Torre Velha, na campanha de 1887 foi posto a descoberto um templo medieval e uma necrópole ${ }^{57}$. Em 2012, a área desta necrópole foi novamente escavada, tendo-se exumado quase duas centenas de indivíduos, cujas ossadas permitiram a realização de análises radiocarbónicas. Destas análises resultaram cronologias de enterramentos entre os séculos VII e XII ${ }^{58}$.

Por seu turno, nos trabalhos desenvolvidos na cidade de Bragança, entre 2002 e 2004, foram escavadas duas necrópoles com cronologias medievais, uma junto à igreja de São João e outra na cidadela, junto à igreja de Santa Maria. Para a primeira zona de enterramento, são apontadas cronologias entre os séculos XIII e XVIII, e para o cemitério da cidadela entre os séculos XII e XIV. Para além destas necrópoles escavaram-se ainda sepulturas junto à igreja de S. Vicente e à capela de S. Sebastião, ambas com cronologias modernas, apesar de se pôr a hipótese de terem existido enterramentos medievais ${ }^{59}$.

Para além destas necrópoles, onde se realizaram trabalhos arqueológicos, há ainda a registar, para o concelho de Bragança, outras referências, situando-se a grande

\footnotetext{
${ }^{55}$ Nomeadamente o Prof. Doutor Pedro Carvalho, coordenador técnico científico do projeto Povo Zoela e o Prof. Doutor Armando Redentor, consultor e colaborador do mesmo projeto.

${ }^{56}$ LIMA, ARGÜELLO MENÉNDEZ, coord., 2004: 21-22.

${ }^{57}$ LEMOS, 1993: I, 44.

${ }^{58}$ Dados referidos pela antropóloga do projeto, Sofia Tereso, e consultados na página online: http://projetozoelas.wix.com. ${ }^{59}$ LIMA, ARGÜELLO MENÉNDEZ, coord., 2004: 47-97. Na publicação não se faz referência se foram ou não realizadas análises radiocarbónicas, dando-se a entender que as cronologias apontadas se basearam nas tipologias das sepulturas e nas suas relações estratigráficas, nomeadamente com os edifícios construídos.
} 
maioria na zona norte ou nas imediações de Bragança ${ }^{60}$. Na região a sul do concelho há apenas quatro ocorrências: nas zonas de Calvelhe, Serapicos, Salsas e Izeda. Nas imediações de Outeiro não há qualquer referência a este tipo de vestígios, contudo poderá pôr-se a hipótese de esta lacuna ser o resultado de possíveis destruições ou da falta de investigação.

No que concerne aos vestígios de povoamento, e baseando-nos nas fontes anteriores, podemos distinguir as referências a povoados fortificados, onde por regra se encontram vestígios de ocupação anterior, da Idade do Ferro e/ou romana, e os «habitats abertos», alguns também com ocupação romana. Dos cerca de 20 povoados medievais identificados, apenas cinco ocupam povoados fortificados, quase todos nas imediações de Bragança e na margem direita do rio Sabor ${ }^{61}$. Apenas Pinela se localiza mais a sul. Os «habitats abertos» têm uma distribuição um pouco mais esparsa, continuando, a grande maioria, a situar-se na órbita da cidade de Bragança ${ }^{62}$, constituindo uma exceção, o povoado que se implanta a sul, entre Pinela e Salsas. Alguns destes habitats encontram-se associados a capelas, igrejas ou necrópoles, contando-se três exemplos com uma possível ocupação alto-medieval. É o caso de Torre Velha, em Castro de Avelãs, de S. Martinho de Carrazedo, povoado fortificado, e de Babe.

Também as fortificações estão associadas à matriz de povoamento, representando um importante papel na estruturação e organização da paisagem. Neste sentido consideraremos aquelas que desempenharam um papel essencialmente de defesa, dado que alguns povoados desta época se desenvolveram em sítios fortificados de épocas anteriores.

Seguindo indicações de Albino Pereira Lopo, Francisco de Sande Lemos aponta como possível a existência de uma fortificação alto-medieval no Monte Cercado de Babe, no lugar chamado Sagrado, onde diz que poderá ter existido um talude no alto do cabeço e um povoado subjacente. Durante as suas prospeções o investigador não encontrou qualquer vestígio desta estrutura, acrescentando que o local estava muito destruído devido aos trabalhos agrícolas ${ }^{63}$. Recordemos que era junto a Babe que passava a via XVII, onde entroncava a estrada secundária vinda das minas de esta-

\footnotetext{
${ }^{60}$ Para a localização dos vestígios do período medieval do concelho de Bragança recorremos aos trabalhos de LEMOS, 1993; ALVES, 2000; LOPO, 1987 e do Portal do Arqueólogo: http://arqueologia.patrimoniocultural.pt. No que se refere às necrópoles ou vestígios funerários do período medieval contabilizamos cerca de 27 ocorrências, onde se incluem todos os registos desta cronologia independentemente da sua tipologia (necrópoles com sepulturas escavadas na rocha, sepulturas delimitadas por pedras avulsas, tampas, sarcófagos e estelas). Dada a falta de trabalhos arqueológicos, não foi possível agrupar estes vestígios por cronologias mais finas. Por fim, acrescentamos que para além das ocorrências referidas a sul do concelho, foram ainda registadas evidências funerárias em Alfaião, São Julião de Palácios, Gostei, Aveleda, Carrazedo, Meixedo, Baçal, Milhão, Rabal, Zeive, Samil, Babe, Carragosa e Faílde.

${ }^{61}$ Segundo os investigadores anteriormente referidos, os povoados fortificados com ocupação medieval situam-se em Espinosela, Donai, Faílde, Torre Velha - Castro de Avelãs, Pinela e Carrazedo.

${ }^{62}$ Estes povoados foram identificados em Nogueira, Izeda, Salsas, Alfaião, Babe, Bragança, Castrelos, Gondezende, Gostei, Zeive, Pinela, S. Pedro de Serracenos e Samil.

${ }^{63}$ LEMOS, 1993: II, 40-41.
} 
nho do planalto de Argozelo-Outeiro. Ainda dentro da mesma cronologia, o autor propõe a existência de uma outra estrutura defensiva no Castro de Coelhoso, em Coelhoso, onde nas vertentes do monte foi identificado um povoado romano ${ }^{64}$. Como já referimos anteriormente, este local situa-se também nas imediações de importantes minas de estanho exploradas em época romana.

Com mais certeza podemos referir o castelo de Alfenim, também conhecido como castelo de Alvelina ou de Pinela, localizado em Pinela. Este local teve ocupação desde a Idade do Ferro até época medieval. Segundo Rita Costa Gomes, e no que se refere a esta última ocupação, a fortificação terá pertencido a um nobre galego e terá assumido funções de cabeça de «terra» ${ }^{65}$. Por seu turno, Paulo Dórdio Gomes acrescenta que a sua construção terá sido promovida por D. Sancho I, num momento anterior a 1187, data em que o monarca dá foral a Bragança, transferindo para esta cidade o "centro da autoridade régia» ${ }^{66}$. Do que ficou exposto poderemos concluir que o castelo de Alfenim terá assumido o comando da Terra de Bragança até 1187, altura em que a cidade recebe foral, assumindo a centralidade militar e administrativa do território.

A norte de Pinela localizava-se ainda o castelo de Rebordãos. Neste local a ocupação humana remontará à Idade do Bronze ou Idade do Ferro, como nos parece sugerir a recolha de um machado de bronze ${ }^{67}$. Depois, já em época medieval, parece ter sido construída uma fortificação que, no foral de 1208, dado à povoação de Rebordãos, é designado como castelo de Tourães, pertencente a um miles. Para além do machado de bronze, foram ainda recolhidas no local pontas de setas e de lanças, guardadas no museu de Bragança ${ }^{68}$.

Finalmente, e para além do castelo de Outeiro, que trataremos de forma individualizada, deixamos uma última nota sobre o castelo de Bragança que, apesar de poder ter sido «fundado» durante o reinado de D. Sancho I, as estruturas que hoje podemos visitar são o resultado das reconstruções iniciadas por D. João I em 1390, obras apenas concluídas durante o reinado de D. Afonso $\mathrm{V}^{69}$.

Integrando o conjunto de estruturas militares, e associadas às fortificações, as atalaias, constituem um vestígio de difícil identificação. No concelho de Bragança é conhecida a atalaia de Candaira, localizada em Baçal. Esta estrutura, cuja construção poderá remontar à época medieval, articulava-se com o castelo de Bragança. Para além desta, Francisco de Sande Lemos, aponta ainda como possível a existência da

\footnotetext{
${ }^{64}$ LEMOS, 1993: II, 72-73.

${ }^{65}$ GOMES, 2003: 11.

${ }^{66}$ GOMES, 1993b: 35.

${ }^{67}$ LEMOS, 1993: II, 125-126.

${ }^{68}$ Informação retirada do Portal do Arqueólogo: http://arqueologia.patrimoniocultural.pt.

${ }^{69}$ MOREIRA, dir., 1989: 70.
} 
atalaia do Penedo da Vela, no lugar de Conlelas, freguesia de Castrelos, e a de Torre de Rabal, em Rabal, ambas junto a Bragança ${ }^{70}$.

Todo o território de Bragança era percorrido por vias que ligavam os diferentes locais com ocupação humana. As duas vias romanas, anteriormente referidas, terão continuado a ser utilizadas em época medieval, articulando-se com outras que, entretanto, foram desenhadas num território em expansão. É Humberto Baquero Moreno, que, através dos itinerários régios, define os principais eixos de comunicação com a região transmontana na Idade Média. A Bragança chegava uma estrada que passando por Carrezedo, Valpaços e Vila Pouca de Aguiar fazia a ligação a Guimarães. Outra partia do Porto, passava por Paço de Sousa, Amarante, Panoias, Murça, chegando depois a Bragança. Desta cidade partia ainda uma via que passava por Alfândega da Fé e Torre de Moncorvo, com ligações à Beira ${ }^{71}$.

Claro que estas vias faziam parte de uma malha mais apertada de caminhos que eram usados pelas populações locais. Alguns destes percursos, cujos vestígios medievais dificilmente identificamos, podem ser adivinhados por caminhos e estradões que atravessam os planaltos, ou mergulham nos vales abruptos, atravessando os

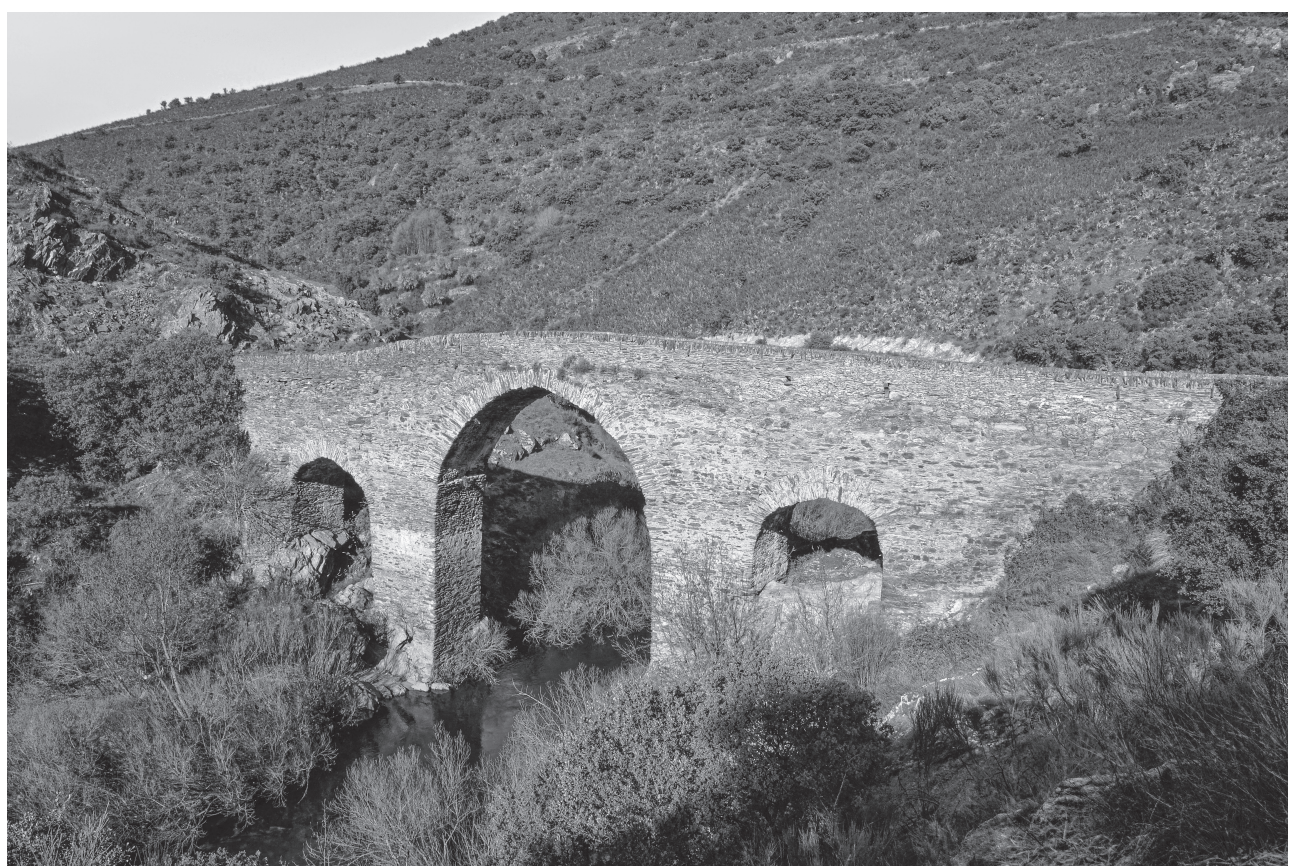

Fig. 2. Ponte de Grijó que atravessa o rio Sabor, ligando Outeiro a Coelhoso

\footnotetext{
${ }^{70}$ LEMOS, 1993: II, 44-45, 63-64, 124-125.

${ }^{71}$ MORENO, 1982.
} 
rios sobre pontes que, apesar de restruturadas, conservam ainda a sua traça medieval. Contam-se algumas em Bragança, mas referiremos apenas a ponte de Grijó, também conhecida por ponte de Parada, que atravessa o rio Sabor, ligando Outeiro a Parada.

Todos estes vestígios medievais não se distribuem no território bragançano num mesmo momento temporal e histórico, sendo cada um marcador diferencial da ocupação humana da região. Sintetizamos de seguida alguns momentos-chave que, direta ou indiretamente, influenciaram esta apropriação territorial.

Como já referimos, os primeiros indícios de ocupação medieval da região de Bragança chegam-nos do século VI, através do Parochiale Suevorum, que nos refere a existência de um pagus chamado Brigantia. Independentemente da localização exata desta paróquia, teremos que considerar os vestígios arqueológicos do século VII, encontrados em Torre Velha, Castro de Avelãs, confirmando a fixação de uma povoação nesta altura. Ainda para o século VII, temos referências a uma moeda visigótica, do reinado de Suintila, proveniente de Pombares ${ }^{72}$. Este achado, juntamente com as referências a necrópoles, são os únicos indicadores de ocupação medieval na zona mais a sul de Bragança, nomeadamente em Salsas e Serapicos ${ }^{73}$.

Relativamente ao período de domínio muçulmano, iniciado após as incursões de Tariq à Península Ibérica no ano de 711, não há, na região bragançana, quaisquer vestígios concretos. A esta lacuna soma-se o "silêncio dos registos cronísticos e mesmo das descrições geográficas que os autores árabes nos legaram», adverte Mário Jorge Barroca, a propósito da zona nordeste do atual território português. Contudo, acrescenta que

este silêncio não deve ser entendido como sintoma de que a zona estava deserta [...] mas, [...] deve ser encarado antes como um reflexo da marginalidade desta área, que nunca chegou a ser plenamente integrada dentro do sistema político do Emirado de Córdova, permanecendo sempre à margem dos grandes eixos do seu espaço político e económico ${ }^{74}$.

No século IX, e durante o processo da Reconquista Cristã, Afonso III das Astúrias avança a linha de fronteira do vale do rio Minho para o vale do rio Douro. Deste avanço resultou a presúria das cidades do Porto em 868 e de Chaves em 872, promovendo a ocupação da zona de Trás-os-Montes ao longo do eixo Chaves-Lamego. Mais tarde, e ainda com o mesmo monarca, a fronteira cristã será alargada a leste resultando, entre outras, na presúria de Zamora em $893^{75}$.

\footnotetext{
72 Informação retirada do Portal do Arqueólogo: http://arqueologia.patrimoniocultural.pt. Registo com o CNS 17488.

${ }^{73}$ Note-se que nos referimos aos limites atuais do concelho de Bragança.

${ }^{74}$ BARROCA, 2008-2009: 201-202.

${ }^{75}$ BARROCA, 2008-2009: 206.
} 
Este alargamento do domínio cristão leva-nos a crer que, nos finais do século IX, a região de Bragança e de Outeiro integrar-se-iam no espaço cristão. Porém, subsistem dúvidas quanto à natureza da sua organização político-administrativa e militar. Tomando como exemplo a orla ocidental de Trás-os-Montes e da Beira Interior, Mário Jorge Barroca diz que não terão existido nesta área civitates, mas antes territórios governados por um conde ou por famílias condais ${ }^{76}$. Esta observação parece ser extensível à região por nós estudada, e talvez explique um certo desinvestimento no chamado processo de encastelamento, justificando a escassez de referências a castelos roqueiros.

Será durante o reinado de Fernando Magno, e beneficiando do avanço da fronteira cristã a sul, que haverá uma alteração na organização territorial. As civitates vão-se desmembrar em terrae, unidades territoriais mais pequenas e entregues a «membros da nova nobreza que se estava a distinguir no manejo das armas, no empenho militar e na lealdade ao monarca» ${ }^{77}$. A estes milites, ou tenentes, eram atribuídas competências militares, administrativas e judiciais. Cada terra tinha um senhor e um castelo.

Em Trás-os-Montes o processo de afirmação das terrae parece ter sido mais tardio. Uma das razões para explicar este facto é apontada por Mário Jorge Barroca, que refere o domínio absoluto dos Braganções, entre a segunda metade do século XI e século XII, impedindo o triunfo de outras famílias nesta região. A terra de Bragança adquiriu nesta altura uma extensão geográfica extraordinária ${ }^{78}$. Entre 1128 e 1145 Fernando Mendes de Bragança II, surge como governador desta terra e com a tenência de Chaves-Montenegro ${ }^{79}$. Mas, apesar de conhecermos os senhores, desconhecemos ao certo qual seria o castelo de comando. Segundo, Paulo Dórdio Gomes, e em data anterior a 1187, D. Sancho I terá promovido a construção do castelo de Pinela, sendo este o centro da autoridade régia nesta região ${ }^{80}$.

Os Braganções tiveram ainda um papel determinante na integração definitiva do território de Bragança no condado Portucalense. As alianças matrimoniais desta linhagem com as famílias de Baião e da Maia parecem demonstrar uma tendência de aproximação ao território português. Esta tendência terá sido encorajada por D. Afonso Henriques que consentiu o casamento de sua irmã com Fernando Mendes de Bragança II, garantindo assim o seu apoio na demarcação de um vasto território de fronteira junto ao reino de Leão. Em 1144 e 1145 o primeiro monarca português vai ainda beneficiar com doações régias o mosteiro de Castro de Avelãs que gozava da proteção desta linhagem ${ }^{81}$.

\footnotetext{
76 BARROCA, 2008-2009: 207.

77 BARROCA, 2003a: 32.

${ }^{78}$ BARROCA, 2008-2009: 218.

${ }^{79}$ PIZARRO, 2007: 855.

${ }^{80}$ GOMES, 1993b: 35.

${ }^{81}$ PIZARRO, 2007: 855-856.
} 
Embora o poder dos Braganções no território de Trás-os-Montes fosse quase absoluto, existiam outras instituições que aqui tinham domínios e exerciam influência. Já referimos o mosteiro de Castro de Avelãs, que juntamente com os cenóbios de Moreruela e de San Martin de Castañeda, com sede no reino vizinho, detinham aqui bens. Para além destes senhores, também as Ordens do Hospital e do Templo beneficiaram com doações nesta região, muitas delas outorgadas pelos condes. Talvez tenha sido através destas doações, que uma parte substancial das terras junto a Outeiro, tenham passado para a posse do mosteiro de Castro de Avelãs e que, mais tarde, seriam escambadas com a Coroa, numa aparente tentativa de prolongar a fronteira portuguesa até às margens do rio Maçãs.

Fernando Mendes de Bragança II morreu sem descendência, sendo possível que alguns dos seus bens tenham ingressado na Coroa. D. Garcia Pires foi o último Braganção à frente de Bragança, entre 1237 e 1238. Entre 1250 e 1256, Bragança será dominada pela linhagem dos de Baião ${ }^{82}$ e em 1265 surge D. Nuno Martins de Chacim como tenente de Bragança ${ }^{83}$.

Será com D. Sancho I que se dará uma nova reorganização administrativa do território português, procurando reforçar o poder real e coartar o domínio crescente da Igreja. Neste sentido o monarca vai conceder mais de meia centena de forais, criando concelhos com dependência direta da Coroa ${ }^{84}$. Na região de Bragança, o Povoador vai outorgar, em 1187, carta de foral a Bragança, integrando nos seus termos a terra de Lampaças. No documento não é mencionada a existência de qualquer castelo, mas é provável que o monarca tenha providenciado a defesa da cidade, pois há notícia que, em 1199, Afonso IX de Leão cercou a povoação. Aliás, e segundo Paulo Dórdio, em 1188 o monarca determina no codicilo ao seu primeiro testamento uma quantia em dinheiro destinada à construção das muralhas da cidade ${ }^{85}$. Neste documento, não datado, mas posterior a 24 de março de 1188, o monarca deixa verba para as obras «in muros de Coviliana et de Benquerencia et de Couna et de Coluche» ${ }^{86}$.

Ainda dentro da política de reforço da fronteira transmontana, D. Sancho I vai conceder foral a Penas Roias em 1187 e a Rebordãos em 1208, onde já se refere um castelo (castelo de Tourães). Para além destas vilas, e segundo Paulo Dórdio Gomes, o monarca terá promovido ainda a construção dos castelos de Pinela e de Algoso, este último na terra de Miranda, em data anterior a $1187^{87}$.

\footnotetext{
82 FREITAS, 2009: 126.

${ }^{83}$ PIZARRO, 2008: 90.

${ }^{84}$ MARQUES, 1995: 217.

${ }^{85}$ GOMES, 1993b: 36.

${ }^{86}$ Documentos de D. Sancho I (1174-1211), 1979: 49-51.

${ }^{87}$ GOMES, 1993b: 35. Como já foi referido anteriormente, e no que diz respeito ao castelo de Pinela ou de Alfenim, este já havia sido ocupado anteriormente. Segundo os investigadores já teria tido funções defensivas antes do reinado de D. Sancho I, contudo, poderá este monarca, ter mandado reforçar as defesas do local.
} 
Os monarcas seguintes continuaram as políticas de centralização do poder real e do reforço das linhas de fronteira com os reinos vizinhos. Paralelamente manteve-se a preocupação de controlar os interesses senhoriais através da realização de inquirições, sobretudo nos reinados de D. Afonso II (1220) e de D. Afonso III (1258). O primeiro monarca confirmará o foral de Bragança, em 1219, e em 1253, D. Afonso III dará novo foral à cidade.

Mas será durante o reinado de D. Dinis que se multiplicarão as cartas de foral, dando seguimento ao esforço da Coroa em aumentar o seu domínio dentro do território português, ao mesmo tempo que tenta promover o povoamento de zonas de fronteira como Bragança. Nesta região serão dados forais a Rebordãos (1285), a Pinelo (1288), a Argozelo (1288), a Santulhão (1288), a Gostei e Castanheira (1289) e a Outeiro de Muías $(1290)^{88}$. Será interessante notar que, grande parte destas povoações situam-se no planalto de Argozelo-Outeiro, distribuindo-se entre os rios Sabor e Maçãs.

O mesmo monarca vai completar uma outra reforma administrativa, já iniciada pelo seu pai, que substituirá as antigas terrae por julgados, cuja jurisdição é entregue pelo rei a um juiz que, auxiliado por um conjunto de funcionários, desempenham funções fiscais, policiais e judiciais. Os antigos tenentes vão progressivamente desaparecendo sem serem substituídos, deixando de ser referidos na documentação a partir de $1287^{89}$.

A esta preocupação de centralizar o poder político exclusivamente na Coroa, aliar-se-á a necessidade de definir os limites geográficos do reino, facto demonstrado pela assinatura do Tratado de Alcañices em 1297, onde se estabeleceram as fronteiras entre Portugal e Castela. Esta definição prolongará o "programa de reformas das estruturas defensivas» que D. Dinis fará executar «entre 1288 e $1315 »^{90}$, e que promoverá obras em mais de meia centena de fortificações. Na região de Trás-os-Montes os castelos intervencionados foram os de Miranda do Douro, Vinhais, Vila Flor, Alfândega da Fé, Mirandela, Freixo de Espada à Cinta, Vila Real, Monforte de Rio Livre, Chaves e Montalegre ${ }^{91}$. Aparentemente, e no que se refere à zona de Bragança, não há notícias de reformas ou construção de fortalezas durante este reinado.

Terminamos neste ponto a análise à ocupação humana da região de Bragança e seguiremos, no capítulo seguinte, os indícios do castelo de Outeiro e da sua povoação, que ganharam contornos mais nítidos precisamente a partir do reinado de $\mathrm{D}$. Dinis.

\footnotetext{
${ }^{88}$ PIZARRO, 2008: 170, 342.

${ }^{89}$ BARROCA, 2003a: 77-78; PIZARRO, 2008: 342.

${ }^{90}$ BARROCA, 2003a: 117.

${ }^{91}$ BARROCA, 1998: 821.
} 

3

DA VILA DE OUTEIRO À CONSTRUÇÃO DO CASTELO 

Depois de termos olhado à distância para o território de Bragança e de termos contextualizado a sua integração nas fronteiras portuguesas, foquemos agora o nosso olhar na povoação de Outeiro e na sua história.

Neste capítulo, analisaremos a evolução da povoação, nomeadamente, o facto de ter passado dos domínios do mosteiro de Castro de Avelãs para a jurisdição da Coroa, transformando-se a pequena aldeia num concelho de fronteira. Num percurso acidentado, foi ampliando e diminuindo os seus termos, «beneficiou» de um castelo e balançou-se entre duas terras transmontanas: Bragança e Miranda do Douro. Desta última ganhou o "apelido», passando a ser referida em muitos documentos como Outeiro de Miranda. Mais tarde, durante a segunda metade do século XVI, integrará a recém-criada diocese de Miranda, que sobreviveu três séculos, perdendo, por fim, a sua sede para Bragança, já havia iniciado o século XIX.

Hoje, Outeiro é uma freguesia do concelho de Bragança, que divide o casario de forma desigual pelas duas margens da ribeira da Vila. Dois núcleos, duas igrejas que parecem refletir a natureza de cada um. No centro, junto ao curso de água, procurando isentar-se das rivalidades, o pelourinho e a casa da câmara, herdados dos tempos de D. Manuel I.

Procuremos, então, conhecer um pouco melhor o longo percurso de Outeiro. Nesta narrativa contaremos com o imprescindível testemunho dos documentos, que confirmam a formação de um território e a necessidade de dotá-lo com o bem mais precioso: gente.

\subsection{AS PRIMEIRAS NOTÍCIAS SOBRE OUTEIRO}

A primeira notícia sobre Outeiro surge num documento de escambo entre D. Sancho I e o mosteiro de Castro de Avelãs. Nele podemos ler que o monarca trocou uma herdade chamada Benquerença, pertencente ao mosteiro de Castro de Avelãs, pela igreja de S. Mamede e as vilas de Santulhão ${ }^{92}$, Argozelo e Pinelo, com os seus termos. Para cada vila escambada são referidas as povoações que lhes serviam de limites. Assim, quando se faz referência a Argozelo, diz-se que esta vila determina com Parada, Carção e Outeiro.

Este documento contém outra informação importante: a data, que nos levantou dúvidas que importa partilhar. Foram consultadas duas versões deste escambo onde se apontavam datas distintas: numa lemos o ano de 1187; noutra o ano de 1194. A data de 1187 é referida pelo Abade de Baçal que, por sua vez, refere outras obras ${ }^{93}$. O ano

\footnotetext{
92 Na Chancelaria de D. Afonso III, 2011: 64, o documento faz referência a uma povoação chamada de S. Julião. De facto, existe uma povoação, junto a Bragança, que se chama S. Julião, contudo fica longe das restantes povoações escambadas. Sendo assim, parece-nos que, a vila de São Julião referida no documento poderá ser Santulhão, que confronta com Izeda, Calvelhe e Carção, e que tem como orago São Julião.

93 ALVES, 2000: III, 49-50.
} 
de 1194 é o indicado por Avelino de Jesus da Costa (nos Documentos de D. Sancho I) e por Leontina Ventura e António Resende de Oliveira (na Chancelaria de D. Afonso $I I I)^{94}$. Ainda sobre esta questão, António Lima e Jorge Argüello Menendez, numa monografia sobre Bragança, dizem que o documento de escambo com a data de 1187 é falso ${ }^{95}$. Já Paulo Dórdio Gomes, na sua dissertação de mestrado, faz referência ao escambo com a data de $1194^{96}$.

Tendo em conta o que foi exposto, parece-nos que o ano de 1194, para datar o escambo, é o mais correto, pois baseia-se diretamente na fonte. Assim, assumiremos essa data como a referência mais antiga a Outeiro. Infelizmente, o documento não adianta outras informações sobre a povoação que, contudo, julgamos que já seria habitada.

Em 1258, Outeiro volta a ser mencionado, agora nas Inquirições de D. Afonso III $^{97}$, e como paróquia de Santa Maria de Outeiro, cuja igreja e vila pertenciam ao mosteiro de Castro de Avelãs. Sessenta e quatro anos depois da primeira referência, ficamos a saber que a povoação era habitada e integrava os domínios do cenóbio beneditino. Para além de Outeiro, o mosteiro tinha ainda as vilas e igrejas de Santulhão, Argozelo, Rio Frio do Monte, Paradinha, Milhão e Pinelo, dominando assim, uma extensa faixa de fronteira entre Bragança e Vimioso.

Aliás, ao lermos as referidas Inquirições, percebemos que toda aquela zona fronteiriça se encontrava fora dos domínios da Coroa portuguesa, pois além das vilas anteriormente referidas, que pagavam foros a Castro de Avelãs, também a diocese de Braga ali detinha coutos, como Paradela. Mas os domínios eclesiásticos nesta região não se limitavam às instituições portuguesas. Também as castelhanas possuíam ali terras, como o mosteiro de San Martin de Castañeda, que comprou umas vinhas em Bragança, e o mosteiro de Moreruela, que detinha a vila de Quintanilha. A sul de Bragança, e entrando nos termos da terra de Miranda, a família de Pedro Ponces de Zamora (Petri Poncij de Zamora) tinha alargado os seus domínios a Vimioso e Miranda, e esta última é referida como pertença de milites e da Ordem do Templo. Nuno Martins de Chacim, que assumirá o cargo de mordomo-mor de D. Afonso III e a tenência de Bragança a partir de $1265^{98}$, surge nesse ano de 1258 com vastas posses nesta região transmontana.

Voltando a Outeiro será novamente o Abade de Baçal que nos dá a conhecer o próximo documento, com data de 1270, e onde o mosteiro de Castro de Avelãs, com

\footnotetext{
${ }^{94}$ Documentos de D. Sancho I (1174-1211), 1979: 118-119; Chancelaria de D. Afonso III, 2011: 64.

${ }^{95}$ LIMA, ARGÜELLO MENÉNDEZ, coord., 2004: 22.

96 GOMES, 1993b: 36.

${ }^{97}$ Portugaliae Monumenta Historica. Inquisitiones, 1961: 1285.

${ }^{98}$ PIZARRO, 2008: 90.
} 
autorização da diocese de Braga, dá carta de aforamento aos moradores da vila, concedendo-lhes benefícios para que se fixem naquela terra e cultivem os seus montes ${ }^{99}$.

Antes de nos determos no conteúdo da carta de foro, verifiquemos o que esteve na sua origem. Assim, numa carta datada de $1266^{100}$, o arcebispo de Braga, D. Martinho Geraldes, responde ao pedido do mosteiro de Castro de Avelãs, revelando o motivo pelo qual é solicitada autorização para aforar os moradores de Outeiro. Diz o documento que o "conventus monasterii de castro de avellanis mandarunt nobis dicere quod tenent quasdam hereditas. et casalia depopulata. et non possunt invenire aliquis qui velint populare ipsas hereditates. et laborare ipsos montes quos sunt pro rumpere» ${ }^{101}$. Foi então com a preocupação de povoar e rentabilizar as terras de Outeiro, que o abade Frutuoso, do referido mosteiro, pediu permissão para conceder benefícios aos habitantes da vila.

Analisado o pedido e concedida autorização, o abade de Castro de Avelãs dá foral a 20 famílias, nomeando-as individualmente, autorizando-as a habitar e trabalhar as terras da vila. No mesmo documento são referidos os direitos e as obrigações dos moradores para com o cenóbio, tais como a obrigação de pagamento de foro em duas prestações anuais ou a isenção da obrigação do maninhádego e da lutuosa. As propriedades ficariam na posse das famílias e dos seus descendentes, sem que estes as pudessem vender ou trocar.

A preocupação de povoar as zonas mais críticas, como as áreas raianas, assumia particular importância. Como temos vindo a verificar, a região de Bragança era dominada por senhorios particulares e eclesiásticos que, durante a primeira centúria do reino, não se limitaram apenas a colher os proventos dos seus domínios, mas contribuíram também para a fixação de populações, enquadrando-as num território em afirmação. Claro que esta ação povoadora beneficiava os seus interesses, na medida em que um maior dinamismo económico trazia mais proventos.

Os esforços desta ação povoadora terão começado a produzir efeitos nos finais do século XIII, fruto de uma conjuntura política e económica favorável, propiciada por um período de paz. Esta situação pode ter beneficiado um certo crescimento populacional e, consequentemente, aumentado os proventos auferidos através das rendas, explicando assim o facto do arcebispo de Braga, D. Fr. Telo, ter concedido ao mosteiro de Castro de Avelãs, em 1287, as décimas das igrejas de várias aldeias, constando, entre elas, Santa Maria de Outeiro ${ }^{102}$.

\footnotetext{
${ }^{99}$ ALVES, 2000: VIII, 135-137.

${ }^{100}$ Segundo MOTA, 2004-2005: 60-61, o pedido de autorização do mosteiro de Castro de Avelãs ao arcebispo para conceder foro, será anterior a 1266, pois nesta data o arcebispo responde ao mosteiro beneditino, incumbindo Rodrigo Fernandes, reitor de Castro Roupal, de se deslocar a Outeiro para ver as herdades e negociar o foro.

101 ALVES, 2000: VIII, 135.

102 ALVES, 2000: III, 57-62.
} 
Mas o domínio absoluto do mosteiro sobre as aldeias de fronteira não duraria muitos mais anos, pois em 14 de setembro de 1290 D. Dinis escamba com o abade do mosteiro de Castro de Avelãs a aldeia de Outer de Muas, perto de Outeiro de Miranda, pelas aldeias de Gustei e Costieira (c. Bragança) ${ }^{103}$.

Neste documento podemos ver refletida a preocupação do monarca em chamar à Coroa o controlo das terras perto da fronteira, dando em troca aldeias situadas junto à sua sede. Esta ação, que marcará o reinado de D. Dinis, vai afastar o domínio do cenóbio transmontano desta zona raiana, domínio esse iniciado no reinado de D. Afonso Henriques, em 1145, com a doação, por parte do monarca, de várias terras entre os rios Maçãs e Sabor ${ }^{104}$. Se no início da afirmação do reino português foi necessária a ajuda dos senhores e da Igreja para fixar populações nas zonas de fronteira, nos finais do século XIII essa responsabilidade é assegurada pela monarquia, através da criação de concelhos, onde funcionários régios zelam pelos interesses da Coroa.

Uma outra observação que este escambo nos merece é o facto de serem mencionadas duas localidades com o nome Outeiro, facto já referido por José Peixoto da Mota $^{105}$. Uma é a aldeia de d'Outeyro de Muas (Outeiro de Muas), que pertenceria a Castro de Avelãs, e que talvez corresponda à paróquia de Santa Maria de Outeiro, referida nas Inquirições de 1258. A outra é Outeiro de Miranda, que não sabemos se seria uma povoação, mas que diz ficar ao pé de Outeiro de Muas: "A aldeya que chamã Outer de Muas a qual aldeya iaz a pee d'Outeyro de Mirãda, como parte cõ Ulgoselo \& cõ Paaço \& cõ Paredina da outra, saluo que retẽ pera ssy a Eygreia cõ sas dizimas \& o casal ẽ que ora a o dicto casal.» ${ }^{106}$ Ficamos, pois, a saber que Outeiro de Muas fica muito próximo de Outeiro de Miranda e que ambas se situam entre Argozelo, Paçô e Paradinha, correspondendo ao local onde hoje se situa Outeiro. Ainda sobre o mesmo documento, chamamos a atenção para o facto de surgir pela primeira vez a designação de Outeiro de Miranda que, possivelmente integraria os domínios da Coroa.

Como explicar esta dupla referência toponímica? Julgamos que uma parte de Outeiro, que ficava na margem sul da ribeira da Vila, incluindo o cabeço onde se ergueu o castelo, pertenceria aos termos de Miranda do Douro, tendo recebido o nome de Outeiro de Miranda ${ }^{107}$. Por seu turno, a aldeia que se desenvolveu junto à igreja, na margem norte da referida ribeira, corresponderia a Outeiro de Muas, outrora Santa Maria de Outeiro, pertencente ao termo de Bragança e aos domínios do mosteiro de Castro de Avelãs. Assim a ribeira da Vila determinava os limites entre

\footnotetext{
${ }^{103}$ As Gavetas da Torre do Tombo, 1962: II, 760. Documento também publicado em SANTANA, 2008: 70-71.

104 SERRÃO, MARQUES, dir., 1996: 34.

${ }^{105}$ MOTA, 2004-2005: 62-63.

106 SANTANA, 2008: 71.

${ }^{107}$ Segundo José Peixoto Pinto da Mota, Outeiro pertenceria aos termos de Miranda do Douro desde 1286, data em que esta vila recebeu foral de D. Dinis. MOTA, 2004-2005: 62.
} 
os dois concelhos e entre os domínios da Coroa e do cenóbio. Apesar de carecer de uma comprovação inequívoca na documentação da época, esta nossa hipótese interpretativa é corroborada pelo facto de, ainda nos nossos dias, serem claramente percetíveis dois núcleos habitacionais autónomos no tecido urbano de Outeiro.

\subsection{DE VILA A CONCELHO}

Já sob o domínio da Coroa, e dando seguimento à política de controlo e povoamento das zonas fronteiriças, D. Dinis dará, no dia 7 de dezembro de 1290, carta de foral a Outeiro de Muas ${ }^{108}$. Este documento é redigido três meses após o escambo no qual a localidade passou a pertencer à Coroa.

O texto abre com uma frase que intitula o documento e que se reveste de interesse. Intitula-se o diploma Carta do foro das aldeas d'Outeyro \& de Muas ${ }^{109}$. Nele são referidas duas aldeias: a de Outeiro e a de Muas. Este facto parece corroborar a nossa sugestão anterior, que admite a existência de dois núcleos populacionais e, por outro lado, indicar a intenção do monarca de juntar as duas aldeias numa só. Podemos também admitir tratar-se simplesmente, um erro de grafia, já que o texto continua dizendo «Dom Denis, pela graça de Deus Rey de Portugal \& do Algarue, a quãtos esta carta uyrẽ faço a saber que eu dou \& outorgo a foro pera todo sempre a uos pobradores da mha aldeya d'Outer de Muas \& a todos uossos sucessores essa mha aldeya» ${ }^{110}$. Assumindo aqui, uma única aldeia, de nome Outeiro de Muas.

Mas apesar das dúvidas ${ }^{111}$, parece-nos que a hipótese por nós sugerida é confirmada na introdução do foral que D. Manuel doa a Outeiro de Miranda em 1514, e que abordaremos mais adiante, onde se faz referência ao documento de D. Dinis. Diz o texto que «Foy primeiramente Imposto nome douteiro dasnas ao dicto lugar que se ora chama outeiro de miranda. depois que do termo de miranda foi tirado certa parte pera o darem por termo ao dito castello» ${ }^{112}$. O texto continua repetindo as condições do foro de D. Dinis que coincidem com o documento de 1290.

E quais eram as condições do foral de D. Dinis, que são as que agora nos interessam? Voltemos ao texto de 1290 que denuncia, uma vez mais, a intenção do monarca de fixar população naquela zona: «Per tal preyto \& per tal cõdiçõ que uos seiades tãtos per todos assy per aqueles que ora hy sodes come per aqueles que hy ueerẽ que façades en essa mha aldeya cẽ casaaes, \& que cada hũu dedes a mĩ \& a todos meus sucessores cada ano: pola festa de Pascoa X soldos, \& pola festa de Sam

\footnotetext{
108 SANTANA, 2008: 72-73.

109 SANTANA, 2008: 72.

${ }^{110}$ SANTANA, 2008: 72.

${ }^{111}$ José Marques, ao abordar a estrutura social e administrativa do nordeste transmontano, assume claramente que «Outeiro de Mulas» é Outeiro. MARQUES, 2004-2005: 16.

${ }^{112}$ Forais Manuelinos do Reino de Portugal e do Algarve: Trás-os-Montes, 1961: 57.
} 
Martinho outros X soldos de Portugal \& senhas ouyauas de centeo en o nouo.» ${ }^{113}$ Pretendia o monarca que se criassem 100 casais que pagariam, cada um, dez soldos pela Páscoa e outros tantos pela festa de S. Martinho. Pelo Ano Novo deveriam pagar uma oitava de centeio.

No texto diz-se ainda que a obrigação de voz e coima é igual à que está descrita no foro de Bragança, devendo os moradores prestar serviço ao monarca, saindo com as suas armas quando necessário. Note-se que na carta não é referida qualquer fortificação, nem é dada indicação para a sua construção.

Os moradores deviam ainda eleger os seus juízes a cada ano e, no caso de o rei doar a aldeia a rico-homem, este não poderia cobrar mais foros do que os estipulados.

Entre outros privilégios e obrigações, o monarca determina que a aldeia, cuja delimitação seria feita pelo seu porteiro Domingos Martins, seria dos moradores e dos seus descendentes, não podendo estes vender as propriedades a cavaleiros, mosteiros, clérigos, escudeiros, filhas d'algo ou religiosos.

Quase um século e meio sob o domínio de particulares, Outeiro passa para a jurisdição da Coroa, tornando-se num pequeno concelho rural de fronteira, com um importante papel na afirmação e definição do território português. Reflexo desta política de definição e proteção de fronteiras, observamos que D. Dinis já havia dado foral a Rebordãos em 1285, a Pinelo, Argozelo e Santulhão em 1288, e a Gostei e Castanheira em 1289114, todas na região de Bragança.

Já depois dos conflitos com Castela, em 1296, e da assinatura do Tratado de Alcañices, em 1297, D. Dinis doa, em 19 de março de 1313, a D. João Afonso, as aldeias de Outeiro de Miranda e de Vila Verde de Bragança ${ }^{115}$. Um ano depois doará, também a este seu filho bastardo, a vila de Rebordãos, «com todos os seus direitos» ${ }^{116}$.

Percebemos que, em 1313, Outeiro de Miranda ficou na posse de D. João Afonso, alferes e mordomo-mor do monarca, e seu fiel partidário na guerra «contra o infante herdeiro D. Afonso» ${ }^{117}$. Quando este último assumiu o trono, em 1325, condenou e mandou executar D. João Afonso, no dia 4 de julho de 1326, confiscando-lhe todos os bens ${ }^{118}$. Outeiro passou então, novamente para os domínios da Coroa.

Já quase no final do reinado de Afonso IV, temos novamente notícias de Outeiro, através de um documento, com data de 28 de agosto de 1355, onde o corregedor e vedor de Trás-os-Montes rejeita o pedido dos moradores da povoação, que pretendiam que se fizesse vila cercada no lugar chamado Outeiro, pedindo que, para tal, o monarca os isentasse do pagamento do foro: «os moradores pedirom ao dicto

\footnotetext{
113 SANTANA, 2008: 72.

114 PIZARRO, 2008: 342-343.

${ }^{115}$ As Gavetas da Torre do Tombo, 1962: II, 31.

116 PIZARRO, 2008: 312.

117 PIZARRO, 2008: 312-313.

${ }^{118}$ MOTA, 2004-2005: 71.
} 
senhor Rei que mandasse cercar e fazer vila cercada no dicto logo d'Outeyro porque diziam que era seu serviço e prol da dicta comarca. E por esto lhi pedirom por mercee que lhis mandasse qitar [sic] o forro que lhi aviam a dar os moradores do concelho ao dicto senhor» ${ }^{119}$.

Este pedido dos moradores da comarca de Outeiro terá sido enviado ao monarca, em data desconhecida, que depois de o ler, deu instruções ao corregedor e vedor para que este «visse que era seu serviço que mandasse aos dictos moradores que a fezessem e lhi desse termho aguisado das vilas e comarca d'arredor e lhis quitasse do forro que lhi em [...] da huum ano aviam a dar como visse que era aguisado» ${ }^{120}$. O funcionário municipal entendeu que o alargamento dos termos de Outeiro para a construção da cerca prejudicaria os concelhos de Bragança e de Miranda, decidindo ouvir as partes envolvidas. Desta consulta resultou a oposição de Bragança e Miranda, dizendo que se devia «enbargar a se nom fazer a dicta cerca nem lhi dar o dicto termho em perjuizo dos dictos concelhos cuja erra a dicta comarca d'Outeiro». Perante isto o corregedor e vedor sentenciou: «eu visto o dicto fecto e consiirando o serviço d'el Rei porque ey em (?) no dicto logo nom se podia fazer cerca nem aver $<$ termho> em perjuizo dos dictos concelhos per sentença julgei que se nom faça cerca em no dicto logo» ${ }^{121}$.

Da leitura do documento fica a certeza que os moradores de Outeiro pretendiam fazer cerca no lugar de Outeiro, que presumimos ser no cabeço onde hoje se ergue o castelo. Para isso, pediam que lhes fossem ampliados os termos da comarca, em prejuízo dos concelhos de Miranda e Bragança, aumentando os seus proventos para ajudar a custear as obras. Note-se que não se faz referência explícita ao castelo, ficando a dúvida se ele já existiria, e se, o que os moradores pretendiam era construir uma cerca, junto a uma fortaleza já existente, para aí construírem habitações. Mas sobre esta questão refletiremos mais adiante.

A primeira referência explícita ao castelo de Outeiro encontra-se num documento da Chancelaria de D. Pedro com a data de 1361, no qual o monarca entrega o castelo a João Rodriguez de Basto, para «que dele faça menagem» ${ }^{122}$.

Segundo Sant'Anna Dionísio, e o seu Guia de Portugal, D. Fernando terá doado a vila de Outeiro «a João Afonso Pimentel como dote da sua cunhada D. Joana Teles de Meneses, irmã bastarda de D. Leonor Teles» ${ }^{123}$. Embora o autor não refira a data da doação esta ocorreu entre 1367 e 1383, período da regência do Formoso. Após

\footnotetext{
119 Trás-os-Montes Medieval e Moderno. Fontes Documentais. Séc. XIV, 2003: doc. 36.

120 Trás-os-Montes Medieval e Moderno. Fontes Documentais. Séc. XIV, 2003: doc. 36.

121 Trás-os-Montes Medieval e Moderno. Fontes Documentais. Séc. XIV, 2003: doc. 36.

122 Chancelarias Portuguesas: D. Pedro I (1357-1367), 1984: 268.

${ }^{123}$ DIONÍSIO, 1995: 924.
} 
a morte deste monarca, João Afonso Pimentel tomou partido por Castela durante o «período crítico do Interregno» ${ }^{124}$, levando D. João I a confiscar todos os seus bens.

Mas Outeiro ficará pouco tempo nas mãos da Coroa e em dezembro de 1385, D. João I doará Outeiro de Miranda a Martim Gonçalves de Macedo, seu escudeiro ${ }^{125}$.

A vila transmontana ficará apenas dois anos na posse do escudeiro porque em março de 1387, D. João I faz nova doação, desta vez a Fernando Afonso, alcaide do castelo de Outeiro de Miranda: «damos e doamos e lhe fazemos liuvre e pura doaçam antre viuos ualledoira deste dia pera todo sempre pera el e pera todos seus filhos e netos lídimos que del // descenderem per linha djreita do nosso lugar d outeiro que Jaz a par do sobredicto castello com todollos seus djreitos e pertenças rendas e foros». ${ }^{126}$ Reforçando a doação ao alcaide, e denunciando uma possível rutura com o anterior escudeiro, acrescenta

mandamos que el per ssy ou per seu procurador possa tomar a posse do dicto lugar e das dictas rendas e direitos e foros delle e as aia logre e possua e faça dello o que lhe prouuer assy como de sua cousa própria sem embargo nemhuu que the sobrello seia posto, nom embargando que nos ouuesemos fecta mercee do dicto lugar e rendas del a Martim gonçalluez de macedo ou a outra algũa pessoa porquanto nossa mercee e vontade he que o aia o dicto fernand afomso e outro nemhuũ nom pella guisa que dicto he E pormetemos de nom reuogar esta sentença nem hir contra ella ${ }^{127}$.

A leitura deste documento deixa transparecer os tempos conturbados que se viviam no reino, logo após a subida ao trono de D. João I e da conquista de várias praças que tinham tomado voz por Castela. Entre estas praças contavam-se Chaves e Bragança, tomadas pelas forças de D. João I cerca de um ano antes ${ }^{128}$.

Em novembro do mesmo ano de 1387, D. João I confirma e outorga «ao concelho e homens boons d outeiro de mjranda todos seus priujllegios foros liberdades e boons custumes» ${ }^{129}$. Neste documento, Outeiro é referido como concelho.

Em dezembro de 1387, um mês depois de confirmar os foros, privilégios e liberdades de Outeiro de Miranda, D. João I «fez doaçam a fernand aafomso alcaide d outeiro de mjranda das rendas e djreitos das aldeas de pinjdello [sic] e d argusello e de santilham» ${ }^{130}$, aumentando assim, os termos do concelho de Outeiro de Miranda,

\footnotetext{
${ }^{124}$ DIONÍSIO, 1995: 924.

${ }^{125}$ Chancelarias Portuguesas: D. João I (1384-1388), 2005: vol. I, tomo 3, 115.

${ }^{126}$ Chancelarias Portuguesas: D. João I (1384-1388), 2005: vol. I, tomo 3, 24.

${ }^{127}$ Chancelarias Portuguesas: D. João I (1384-1388), 2005: vol. I, tomo 3, 24.

${ }^{128}$ COELHO, 2008: 403.

${ }^{129}$ Chancelarias Portuguesas: D. João I (1384-1388), 2005: vol. I, tomo 3, 229.

${ }^{130}$ Chancelarias Portuguesas: D. João I (1384-1388), 2005: vol. I, tomo 3, 143.
} 
com as aldeias de Pinelo, Argozelo e Santulhão, que pertenceriam aos termos de Miranda (Mapa 2).

Contudo, esta expansão de domínios concelhios não duraria muito, porque em janeiro de 1395, o mesmo monarca manda «que as aldeas de pinhello e de santelham e d algosello», incluídas, há sete anos atrás, no termo do concelho de Outeiro de Miranda, «seiam do termo e jurdiçam da ujlla de mjranda como antijgamente eram E nom do termo d outeiro de mjranda» ${ }^{131}$.

Além de ver reduzido os seus termos, Outeiro de Miranda também irá mudar de «senhor». Os primeiros indícios desta mudança chegam-nos através de uma doação, com data de fevereiro de 1392, em que D. João I doa a Martim Gonçalves de Macedo, seu escudeiro, as «dizimas e portagens de bragança e d aldeã d outeiro de mjranda» ${ }^{132}$. Cinco anos depois, o monarca volta a agraciar o escudeiro, doando-lhe privilégios na região de Bragança.

Este reconhecimento torna-se mais evidente em dezembro de 1400, quando D. João I «fez doaçam emquanto fosse sua mercee a martim gonçalluez de macedo seu uasallo e alcaide do seu castello d outeiro de mjranda, de todallas dizimas dos panos que veem de castella ao dicto lugar d outeiro de mjranda E de todollos outros djreitos que o dicto senhor no dicto lugar há» ${ }^{133}$. Parece claro que para além de voltar a ter sido nomeado alcaide do castelo de Outeiro de Miranda, Martim Gonçalves de Macedo foi ainda recompensado com as dízimas sobre a venda «dos panos», que vinham de Castela.

Para além do monarca voltar a confiar no seu escudeiro, podemos deduzir que os tempos conturbados de guerra conheceram uma acalmia e muito provavelmente ter-se-á assistido a um incremento nas trocas comerciais entre Portugal e Castela, aumentando assim as receitas provenientes dos impostos.

Esta conjuntura favorável talvez tenha propiciado um certo crescimento populacional, dado que em 1414 os moradores de Outeiro de Miranda pedem ao monarca para construírem casas dentro da cerca do castelo, que já tinha sido iniciada. Neste documento, que analisaremos com pormenor no próximo capítulo, o monarca especifica quem irá fazer a concessão dos terrenos, como deve ser feita e como deverão ser construídas as casas:

Porem fiando nos do dom abade de crasto d auellaãs alcaide do dicto castello per esta carta lhe damos poder e the mandamos que elle possa dar e de os chaãos de dentro da dicta cerca aos do dicto lugar e de fora delle que hi quiserem fazer casas e morar e pobrar em ellas Repartindo lhes os chaños segundo ujr que cada

\footnotetext{
${ }^{131}$ Chancelarias Portuguesas: D. João I (1387-1402), 2005: vol. II, tomo 2, 165.

132 Chancelarias Portuguesas: D. João I (1385-1392), 2005: vol. II, tomo 1, 303.

${ }^{133}$ Chancelarias Portuguesas: D. João I (1391-1407), 2005: vol. II, tomo 3, 170.
} 
huũ merece e que as casas seiam fectas em boa hordenanças pera as Ruas vijrem bem fectas E que estes chaãos de aos que assy qujserem morar e pobrar em o dicto lugar pera sempre pera eles e pera todos seus herdeiros e descendentes que depos eles vierem sem pagando a nos e aos reis que despois de nos vierem nemhũa cousa das dictas casas $^{134}$.

Mas, quatro anos depois, em fevereiro de 1418, D. João I volta a escrever mostrando-se preocupado porque o castelo de Outeiro de Miranda estava muito despovoado «por o dicto lugar teer muy pequeno termo e de muy poucas gentes» ${ }^{135}$. Identificado o problema, D. João I aponta as medidas para a sua solução:

Teemos por bem e damos the por seu termo estas aldeas que se adiante seguem .s. há aldea e lugar de pinhello e aldea e lugar d algusello e aldea e lugar de samtulham que ora som pobradas e aldea de garçam [sic] e de ual de pena que stam acerca do dicto castello e som despobradas que som em termo de miranda $E$ a aldea e lugar de paradinha / E a alede $<a>$ [sic] e lugar de paçoo e aldea e lugar de Rio frio e aldea e lugar de milhom que som em termo de bragança E aldea $e$ lugar de quintanjlha e as ueegas que ora stam despobradas as quaães aldeas $e$ lugares som bem açerqua do dicto lugar e moram em ellas ao tempo d ora cento homens. Acrescentando: [...] queremos e mandamos que daquj en diante pera todo sempre as dictas aldeas e lugares sobredictos seiam termo próprio e Jsento do dicto logo d outeiro de mjranda [...] E mandamos e outorgamos que o dicto lugar se aproveite e possa aproveitar das dictas aldeas e lugares e moradores deles como de seu termo próprio e de sua Jurdiçom ${ }^{136}$.

Resumindo, o monarca que aumentou os termos de Outeiro em 1387 e que os retirou em 1395, em favor de Miranda, acabou por voltar a incluir, em 1418, as aldeias de Pinelo, Argozelo e Santulhão, nos termos de Outeiro, e acrescentar a aldeia de Carção, e «ual de pena», dois lugares também do termo de Miranda e que estavam despovoados. Para além destas aldeias integra ainda a aldeia e lugar de Paradinha, Paçô, Rio Frio e Milhão, que pertenciam ao termo de Bragança. Por fim, acrescenta a aldeia e lugar de Quintanilha e as suas veigas que se encontravam despovoadas. Segundo o mesmo documento todas estas aldeias ficavam próximas de Outeiro de Miranda e totalizavam, à época, cem homens (Mapa 3).

Contudo, o problema do despovoamento continua a agudizar-se e, em 1421, D. João I volta a intervir, respondendo à preocupação do infante D. Pedro que infor-

\footnotetext{
${ }^{134}$ Chancelarias Portuguesas: D. João I (1410-1418), 2006: vol. III, tomo 3, 173.

${ }_{135}$ Chancelarias Portuguesas: D. João I (1410-1425), 2006: vol. IV, tomo 1, 26-27.

${ }^{136}$ Chancelarias Portuguesas: D. João I (1410-1425), 2006: vol. IV, tomo 1, 26-27.
} 
mou o pai «que a nossa villa d outeiro de mjranda he muy despobrada per aazo das guerras e pestilências». Por isso, «pedia por mercee que desemos lugar e licença a cinquoenta homjziados que pudessem viuer e star coutados no dicto logo» ${ }^{137}$.

Falhadas as tentativas anteriores de repovoar Outeiro, o infante D. Pedro pede ao monarca para autorizar a fixação de 50 homiziados na aldeia. Consciente que esta poderia ser a única forma de fixar população nesta região de fronteira, o monarca ordena: «mandamos que ataa $\mathrm{L}^{\text {ta }}$ homens homiziados posto que seiam culpados em quaãesquer malefícios que seiam Comtanto que esses malefícios em que forem culpados nom seiam $d$ aleiue ou de traiçom se possam hir pera o dicto lugar d outeiro de mjranda e viuam em el e seiam hi courados». Acrescentando ainda «E queremos e mandamos que esses omeziados [...] aiam em cada huũ anno dous meses de licença pera hirem aos lugares de dentro dos nossos regnos buscar seus mantijmentos» ${ }^{138}$. Durante esta licença o monarca determina que o homiziado possa andar pelo reino, sem ser preso, contando que não entre nos lugares e termos onde cometera o crime.

A solução de estabelecer coutos de homiziados em lugares despovoados parece ter-se iniciado com D. Dinis, que poderá ter criado o primeiro em Noudar em 16 de janeiro de $1308^{139}$. Este ato, aparentemente isolado, não teve grande repercussão nos dois reinados seguintes, mas revelou-se recorrente durante os reinados de D. Fernando e D. João I, talvez como resposta às consequências das guerras que devastaram as zonas de fronteira.

Os coutos acabaram por ser abolidos por D. Pedro II, e os seus privilégios cessaram definitivamente em $1790^{140}$. Na região de Trás-os-Montes, Bragança receberá couto de homiziados em 1439, 18 anos depois de Outeiro, e Vimioso em $1494^{141}$.

Durante os reinados posteriores a D. João I não recolhemos notícias sobre o concelho de Outeiro de Miranda. Devemos ressalvar, no entanto, que a documentação régia relativa a estes reinados, com exceção da Chancelaria de D. Duarte, não se encontra publicada, o que não permitiu uma pesquisa exaustiva. Em todo o caso, o concelho de Outeiro de Miranda só volta a ser referido no foral de D. Manuel, concedido em 11 de novembro de 1514.

No início do documento que o Venturoso mandou lavrar faz-se referência ao nome pelo qual a aldeia era conhecida: Outeiro de Asnas. Como já referimos e justificamos anteriormente, julgamos que este Outeiro de Asnas é o mesmo Outeiro de Muas a quem D. Dinis deu foral em 1290, e que agora se chamava Outeiro de Miranda.

\footnotetext{
${ }^{137}$ Chancelarias Portuguesas: D. João I (1410-1418), 2006: vol. III, tomo 3, 139.

${ }^{138}$ Chancelarias Portuguesas: D. João I (1410-1418), 2006: vol. III, tomo 3, 139.

${ }^{139}$ Sobre coutos de homiziados ver: MORENO, 1974 e MORENO, 1986b.

${ }^{140}$ MORENO, 1986b: 94-99.

${ }^{141}$ MARQUES, 2004-2005: 34.
} 
Começa então o documento: «Foy primeiramente Imposto nome douteiro dasnas ao dicto lugar que se ora chama outeiro de miranda.» ${ }^{142} \mathrm{E}$ como que justificando esta alteração do nome, diz-se que parte do termo de Outeiro foi retirada a Miranda, para ser entregue ao castelo daquela vila: «depois que do termo de miranda foi tirado certa parte pera o darem por termo ao dito castelo» ${ }^{143}$. Acrescenta-se ainda que os foros que as aldeias pagavam a Miranda, passariam a ser pagos a Outeiro de Asnas «com condiçam que fezessem nelle cem casaaes», referindo de seguida os foros a pagar: «cada hum dos quaes pagariam em cada hum Anno trinta e seis reaaes pollos vinte soldos que se no dicto foral por elles mandava pagar a metade por pascoa e a outra por sam martinho e ora os povoadores sejam muitos ou poucos toda vya ham de pagar a dicta conthia dos dictos Cem casaes.» Mais "huuma oitava de centeo paga no Novo» ${ }^{144}$. São estes os mesmos termos que constam no foral de 1290.

Para além do que já havia sido acordado, o legislador acrescenta que «tem mais de Renda o dicto Castello huma Aldea que chamam de Veigas que estaa agora aforada a çertas pessoas Declaradas em sua escriptura per que paguam trezentos alqueires de Centeeo e dozentos reaaes em dinheiro e dous carneiros e dez galinhas». E «paga mais ao senhorio polla aldeã de Quintanilha. Cinquoenta alqueires de trigo Segundo que Antre sy se Reparte como atee qui fezeram» ${ }^{145}$. Como já tínhamos visto, estas aldeias passaram a fazer parte do termo de Outeiro de Miranda em 1418, durante o reinado de D. João I.

Relativamente às restantes obrigações, o monarca manda que se siga o foral de Bragança, tal como havia sido sugerido também no foral de D. Dinis. Assim se deverá proceder quanto à pena de arma «se Recada pollo alcaide E levam se aquy pollo foral de Bragança na maneira em que mandamos laa que se mais nam leve se faraa aquy somente dozentos reaaes contheudos em nossas ordenaçooens e as armas perdidas Os quaaes o Senhorio Reparta como quiser per sy e seu alcaide pois tudo hé de huuma pessoa»; às obrigações relativas ao "gado do vento»; à portagem «Salvo que nam tem os capítulos dalfandega nem tem privillegio de portagem»; e à passagem, que «se entederá naquelas mercadorias somente que partindo da dicta villa ou de seu termo ajam dentrar logo em terra de castella ou vindo de castella entrem primeiramente na dita villa ou em seu termo ante que em outro luguar» ${ }^{146}$.

\footnotetext{
${ }^{142}$ Forais Manuelinos do Reino de Portugal e do Algarve: Trás-os-Montes, 1961: 57.

${ }^{143}$ Forais Manuelinos do Reino de Portugal e do Algarve: Trás-os-Montes, 1961: 57.

${ }^{144}$ Forais Manuelinos do Reino de Portugal e do Algarve: Trás-os-Montes, 1961: 57.

${ }^{145}$ Forais Manuelinos do Reino de Portugal e do Algarve: Trás-os-Montes, 1961: 57.

${ }^{146}$ Forais Manuelinos do Reino de Portugal e do Algarve: Trás-os-Montes, 1961: 57.
} 
Embora o foral de D. Manuel I apenas faça referência às aldeias de Quintanilha e Veigas como integrando o termo de Outeiro de Miranda, Anselmo Braamcamp Freire revela que no Numeramento Geral do Reino, de 1527-31, a vila tinha como termo as mesmas aldeias referidas em 1418: Santulhão, Carção, Argozelo, Pinelo, «Val de Pena», Paradinha, Quintanilha, Veigas, Milhão, Rio Frio e Paço. Para além de nomear as aldeias, o autor indica mesmo os limites do concelho:

de hũ cabo do termo ao outro, coatro legoas boas e ẽ largo hũa; e parte e confina com os concelhos seguintes: Parte e confina com a villa do Vymioso, que he de hũa villa á outra duas legoas. Parte e confina com a villa dAlgoso, que he de hũa villa á outra coatro legoas. Parte mais e confina com a cidade de Bragança, que he da dita vila á dita cidade três legoas. Parte e confina mais com a villa de Bemnavete, que he de hũa villa á outra catorze legoas, a saber: ao estremo, duas, e doze a Bemnavete; he senhor de Benavẽte o Conde de Benavẽte. Parte e confina mais com a villa dAlcaniças, que jaz nos ditos regnos de Castella e he de dom Francisco Amriqez, e he de hũa villa á outra coatro legoas, a saber: ao estremo, hũa; e do estremo Alcaniças, três, e quy se torna a juntar o termo desta villa com o do Vymioso ${ }^{147}$. (Mapa 3)

Numa nota sobre a população, o autor acrescenta que neste extenso concelho de Outeiro de Miranda viviam 596 moradores, 62 dos quais em Outeiro.

O último documento que recolhemos e que nos dá notícia sobre Outeiro são as Memórias Paroquiais de 1758, onde se pode ler que a vila de Outeiro

Hé da Provincia de Trás os Montes, Bispado de Miranda, Comarca de Bragança, freguesia in solidum, hé da Casa Excelentissima de Bragança, e ao presente está unida aos lugares da Coroa. Tem noventa vizinhos e duzentas e setenta pessoas. Está situada em planicie parte e outra ocupa lugar mais agreste, porém nam se descobre mais que o lugar da Paradinha ${ }^{148}$.

Antes de mais devemos observar que Outeiro passou a fazer parte da Casa de Bragança em 1440, com a doação de D. Pedro, regente do reino durante a menoridade de D. Afonso V, da cidade de Bragança e Outeiro a D. Afonso, filho ilegítimo de D. João I. Depois, devemos notar que Outeiro passou a fazer parte da diocese de Miranda do Douro aquando da sua criação em 1545. Estes dois assuntos serão desenvolvidos noutros pontos adiante.

\footnotetext{
147 FREIRE, 1909: VII, 265.

${ }^{148}$ CAPELA et al., 2007: 294-297.
} 
A segunda observação, que o parágrafo acima transcrito nos merece, relaciona-se com a descrição da vila de Outeiro, que se localiza uma parte na "planície» e outra num «lugar mais agreste», acrescentando-se depois que, porém, apenas tem um lugar: Paradinha. Como já referimos anteriormente, Outeiro ainda hoje apresenta, tal como no século XVIII, dois núcleos populacionais distintos. Um fica na "planície», onde se ergueu a igreja de Santo Cristo, e que corresponderia ao Outeiro de Miranda do foral de 1290, e outra parte da aldeia situava-se no «lugar mais agreste», junto à igreja matriz, e que corresponderia ao Outeiro de Muas do mesmo foral. Contudo, o autor chama a atenção que não se tratava de dois lugares diferentes, pois Outeiro teria apenas o lugar de Paradinha, que fica a nordeste da vila. Pensamos que esta descrição reforça a ideia de que D. Dinis juntou, em 1290, dois lugares numa única povoação, dando-lhe foral, e que mais tarde passou a ser designada como Outeiro de Miranda.

Voltando às Memórias Paroquiais, ficamos a saber que os termos de Outeiro são as aldeias de Argozelo, Carção, Santulhão, Milhão, Rio Frio, Paço, Veigas, Quintanilha, Paradinha e Pinelo. Confirmando que, com exceção de «val da pena», Outeiro manteve os mesmos termos desde 1418.

Segundo o mesmo documento, ficamos a saber que o orago da igreja matriz é Nossa Senhora da Assunção ${ }^{149}$ e que existem duas ermidas fora da vila, uma dedicada a Santa Bárbara e a outra a S. Roque. Dentro da vila, e para além da igreja matriz, refere-se ainda a «cappella do Santo Christo de Outeiro, hum dos mais magníficos e sumptuosos templos que há nam só nesta Provincia, mas em todo o Reino, e ainda nos mais da Europa, que se edificou de esmolas em cujo sentido falo» ${ }^{150}$.

Já na parte final do inquérito, são dadas informações sobre o sustento e a economia das gentes de Outeiro dizendo-se que «Nesta terra há creaçam de gados ovelhuns e alguns cabruns, bezerros, enxames». Acrescentando-se que a vila se situa

no meio de dois rios, hum chamado o rio Sabor, que fica distante hum bom quarto de legoa, que todo o anno corre, o outro o rio Maçans, que também corre todo o anno, aquelle de curso mais arrebatado que este, o qual fica menos distante. De ambos se valem os moradores para moerem o pam, as arribas de hum e outro são muito agrestes de matos, de estevas, carrascos, em partes se semea pam centeio. Os peixes que produzem são barbos, escalos, bogas e alguas inguias... tem muitas moendas de moinhos e as suas pescarias são livres ${ }^{151}$.

\footnotetext{
${ }^{149}$ Nas Inquirições de 1258 a paróquia chamava-se Santa Maria de Outeiro. Pelo que pudemos constatar, a alteração da designação do orago para Nossa Senhora da Assunção, surge na documentação por volta de 1858, já depois da mudança da sede diocesana de Miranda para Bragança.

${ }^{150}$ CAPELA et al., 2007: 294-297.

${ }^{151}$ CAPELA et al., 2007: 294-297.
} 
Tabela 1. Cronologia da povoação de Outeiro segundo os documentos

\begin{tabular}{|c|c|c|}
\hline 1194 & $\begin{array}{l}\text { Escambo entre D. Sancho I e o mosteiro de Castro de Avelãs. Outeiro é } \\
\text { referido como limite de Argozelo. }\end{array}$ & $\begin{array}{l}\text { Documentos de D. Sancho I (1174- } \\
\text {-1211), 1979: 118-119; Chancelaria de } \\
\text { D. Afonso III, 2011: doc. } 30 .\end{array}$ \\
\hline 1258 & $\begin{array}{l}\text { Outeiro surge mencionado nas Inquirições de } 1258 \text { como paróquia de } \\
\text { Santa Maria de Outeiro, pertencente ao mosteiro de Castro de Avelãs. }\end{array}$ & $\begin{array}{l}\text { Portugaliae Monumenta Historica. } \\
\text { Inquisitiones, 1961: } 1285 .\end{array}$ \\
\hline 1270 & Carta de foro dada pelo mosteiro de Castro de Avelãs a 20 famílias de Outeiro. & ALVES, 2000: VIII, 135-137. \\
\hline 1287 & $\begin{array}{l}\text { O arcebispo de Braga, D. Telo, concede ao mosteiro de Castro de Avelãs, } \\
\text { as décimas das igrejas de várias aldeias, entre elas, Santa Maria de Outeiro. }\end{array}$ & ALVES, 2000: III, 57-62. \\
\hline $\begin{array}{l}1290, \text { setembro, } \\
14\end{array}$ & $\begin{array}{l}\text { O rei D. Dinis escamba com o abade do mosteiro de Castro de Avelãs a } \\
\text { aldeia de Outer de Muas, perto de Outeiro de Miranda, pelas aldeias de } \\
\text { Gustei e Costieira (c. Bragança). }\end{array}$ & $\begin{array}{l}\text { As Gavetas da Torre do Tombo, 1962: } \\
\text { II, 760; } \\
\text { SANTANA, 2008: 70-71. }\end{array}$ \\
\hline $\begin{array}{l}\text { 1290, } \\
\text { dezembro, } 07\end{array}$ & D. Dinis dá carta de foral a Outeiro de Muas. & SANTANA, 2008: 72-73. \\
\hline $\begin{array}{l}\text { 1313, } \\
\text { março, } 19\end{array}$ & $\begin{array}{l}\text { D. Dinis doa a D. João Afonso, seu filho bastardo, as aldeias de Outeiro de } \\
\text { Miranda e de Vila Verde de Bragança. }\end{array}$ & $\begin{array}{l}\text { As Gavetas da Torre do Tombo, 1962: } \\
\text { II, } 31 .\end{array}$ \\
\hline $\begin{array}{l}\text { 1355, } \\
\text { agosto, } 28\end{array}$ & $\begin{array}{l}\text { O corregedor e vedor de Trás-os-Montes rejeita o pedido dos moradores } \\
\text { de Outeiro de Miranda, que pretendiam que se fizesse vila cercada no } \\
\text { lugar chamado Outeiro. }\end{array}$ & $\begin{array}{l}\text { Trás-os-Montes Medieval e Moderno. } \\
\text { Fontes Documentais. Séc. XIV, 2003: } \\
\text { doc. } 36 .\end{array}$ \\
\hline 1385 & $\begin{array}{l}\text { D. João I doa Outeiro de Miranda a Martim Gonçalves de Macedo, seu } \\
\text { escudeiro. }\end{array}$ & $\begin{array}{l}\text { Chancelarias Portuguesas: D. João I } \\
\text { (1384-1388), 2005: vol. I, tomo 3, } 115 .\end{array}$ \\
\hline $\begin{array}{l}1387, \\
\text { março }\end{array}$ & $\begin{array}{l}\text { D. João I faz doação de Outeiro de Miranda a Fernando Afonso, alcaide } \\
\text { do castelo. }\end{array}$ & $\begin{array}{l}\text { Chancelarias Portuguesas: D. João I } \\
\text { (1384-1388), 2005: vol. I, tomo 3, } 241 .\end{array}$ \\
\hline $\begin{array}{l}1387, \\
\text { novembro }\end{array}$ & $\begin{array}{l}\text { D. João I confirma e outorga todos os privilégios, foros, liberdades e bons } \\
\text { costumes ao concelho e homens bons do concelho de Outeiro de Miranda. }\end{array}$ & $\begin{array}{l}\text { Chancelarias Portuguesas: D. João I } \\
\text { (1384-1388), 2005: vol. I, tomo 3, } 229 .\end{array}$ \\
\hline 1387 , dezembro & $\begin{array}{l}\text { D. João I doa a Fernando Afonso, alcaide de Outeiro de Miranda, as rendas } \\
\text { e direitos aldeias de Pinelo, Argozelo e Santulhão, que pertenceriam aos } \\
\text { termos de Miranda. }\end{array}$ & $\begin{array}{l}\text { Chancelarias Portuguesas: D. João I } \\
\text { (1384-1388), 2005: vol. I, tomo 3, } 143 .\end{array}$ \\
\hline $\begin{array}{l}\text { 1392, } \\
\text { fevereiro }\end{array}$ & $\begin{array}{l}\text { D. João I doa a Martim Gonçalves de Macedo, seu escudeiro, as dízimas e } \\
\text { portagens de Bragança e de Outeiro de Miranda. }\end{array}$ & $\begin{array}{l}\text { Chancelarias Portuguesas: D. João I } \\
\text { (1385-1392), 2005: vol. II, tomo 1, } 303 .\end{array}$ \\
\hline $\begin{array}{l}\text { 1395, } \\
\text { janeiro }\end{array}$ & $\begin{array}{l}\text { D. João I manda que as aldeias de Pinelo, Argozelo e Santulhão, deixem de fazer } \\
\text { parte dos termos de Outeiro de Miranda e voltem para a jurisdição de Miranda. }\end{array}$ & $\begin{array}{l}\text { Chancelarias Portuguesas: D. João I } \\
\text { (1387-1402), 2005: vol. II, tomo 2, } 165 .\end{array}$ \\
\hline 1400 , dezembro & $\begin{array}{l}\text { D. João I faz doação a Martim Gonçalves de Macedo, alcaide do castelo de } \\
\text { Outeiro de Miranda, de todas as dízimas dos panos que vêm de Castela para } \\
\text { aquela povoação e de todos os outros direitos sobre a mesma. }\end{array}$ & $\begin{array}{l}\text { Chancelarias Portuguesas: D. João I } \\
\text { (1391-1407), 2005: vol. II, tomo 3, } 170 .\end{array}$ \\
\hline 1414 & $\begin{array}{l}\text { Os moradores de Outeiro de Miranda pedem ao monarca para construírem } \\
\text { casas dentro da cerca do castelo, cuja construção se encontrava em curso, } \\
\text { tendo-lhes sido concedida autorização. }\end{array}$ & $\begin{array}{l}\text { Chancelarias Portuguesas: D. João I } \\
\text { (1410-1418), 2006: vol. III, tomo 3, } 173 .\end{array}$ \\
\hline $\begin{array}{l}\text { 1418, } \\
\text { fevereiro }\end{array}$ & $\begin{array}{l}\text { D. João I mostrando-se preocupado porque o castelo de Outeiro de Miranda } \\
\text { está muito despovoado, aumenta-Ihe os termos, acrescentando as aldeias } \\
\text { de Miranda e de Bragança. }\end{array}$ & $\begin{array}{l}\text { Chancelarias Portuguesas: D. João I } \\
\text { (1410-1425), 2006: vol. IV, tomo 1, } \\
\text { 26-27. }\end{array}$ \\
\hline 1421 & $\begin{array}{l}\text { D. João I, a pedido do infante D. Pedro, cria um couto de homiziados em } \\
\text { Outeiro de Miranda, com } 50 \text { homens. }\end{array}$ & $\begin{array}{l}\text { Chancelarias Portuguesas: D. João I } \\
\text { (1410-1418), 2006: vol. III, tomo 3, } 139 .\end{array}$ \\
\hline $\begin{array}{l}\text { 1514, } \\
\text { novembro, } 11\end{array}$ & D. Manuel dá foral a Outeiro. & $\begin{array}{l}\text { Forais Manuelinos do Reino de } \\
\text { Portugal e do Algarve: Trás-os-Montes, } \\
\text { 1961: } 57 .\end{array}$ \\
\hline $\begin{array}{l}\text { 1545, } \\
\text { maio, } 22\end{array}$ & Bula de criação da Sé de Miranda do Douro, da qual fará parte Outeiro. & ALVES, 2000: III, 9-19. \\
\hline 1758 & $\begin{array}{l}\text { Nas Memórias Paroquiais de } 1758 \text { diz-se que Outeiro pertence à Casa } \\
\text { de Bragança e à diocese de Miranda. Nessa altura mantinha os mesmos } \\
\text { termos de } 1418 \text {. }\end{array}$ & CAPELA et al., 2007: 294-297. \\
\hline
\end{tabular}

Fonte: Elaboração própria 
Se considerarmos que Outeiro recebeu foral em 1290, constituindo-se nessa altura num pequeno concelho de fronteira, cujos termos se limitariam à própria vila, mas que era dado o direito aos moradores para escolherem o juiz, teremos que concluir que foi concelho durante 563 anos, pois só foi extinto em 31 de dezembro de 1853.

Ao longo desses séculos, Outeiro participou na história acompanhando e refletindo as suas mudanças e transformações. Longe das zonas de influência e dos principais eixos de circulação, a povoação manteve-se pela graça dos clérigos, que teimaram no seu desenvolvimento. Depois a vontade política ambicionou uma fronteira e precisou que alguém a guardasse. Era necessário fixar as gentes à terra, dar-lhes razões para ficar. E assim cresceu Outeiro, umas vezes com coragem, outras com desânimo, sempre entre os dois grandes: Bragança e Miranda.

\subsubsection{Testemunhos da história de Outeiro}

Percorrida a formação, o crescimento e o declínio do concelho de Outeiro, analisaremos agora os testemunhos materiais deixados pela sua história. A memória desse passado lê-se antes de mais no desenho da vila, onde sobressai o casario agrupado em dois núcleos: um na "planície» e outro num «lugar mais agreste» ${ }^{152}$ (ver Fig. 1).

O núcleo que fica no «lugar mais agreste», na margem norte da ribeira da Vila, será o correspondente à povoação mais antiga, à aldeia de Outeiro de Muas. O casario mais antigo parece ter ocupado a vertente sudeste, virada à linha de água, onde também foi erguida a igreja matriz. Com o tempo o casario foi-se espalhando pelo pequeno cabeço, preenchendo-o com construções recentes.

As casas mais antigas usam o xisto como material predominante de construção. Algumas têm as paredes nuas, mas outras conservam restos de reboco de cal. A sua planta é quadrangular ou retangular, funcionando o rés do chão como corte de animais. O primeiro piso é sobradado e o acesso é feito pelo exterior através de escadaria em pedra. As portas e janelas têm padieiras e ombreiras em madeira e os telhados são de duas águas, cobertos com telha de meia cana. Apesar das cronologias contemporâneas destas construções, não deixa de ser interessante comparar a distribuição do casario neste núcleo mais antigo, com a representação da aldeia nos desenhos de Duarte de Armas, que parece, em parte, corresponder ao mesmo espaço.

A igreja matriz de Outeiro, que se situa neste núcleo mais antigo da aldeia, não ocupa um lugar central, mas ergue-se na extremidade leste da vertente ${ }^{153}$. Apresenta uma planta retangular, com orientação oeste-este, sobressaindo apenas o corpo da sacristia na zona da cabeceira, na lateral norte. A porta da igreja abre-se na fachada sul, construída em cantaria de granito e formando um arco de volta perfeita, prote-

152 CAPELA et al., 2007: 294-297, doc. 34.

${ }^{153}$ A igreja matriz de Outeiro é classificada como Imóvel de Interesse Municipal pelo Decreto n. ${ }^{\circ}$ 67/97. PORTUGAL. Ministério da Cultura, 1997. 


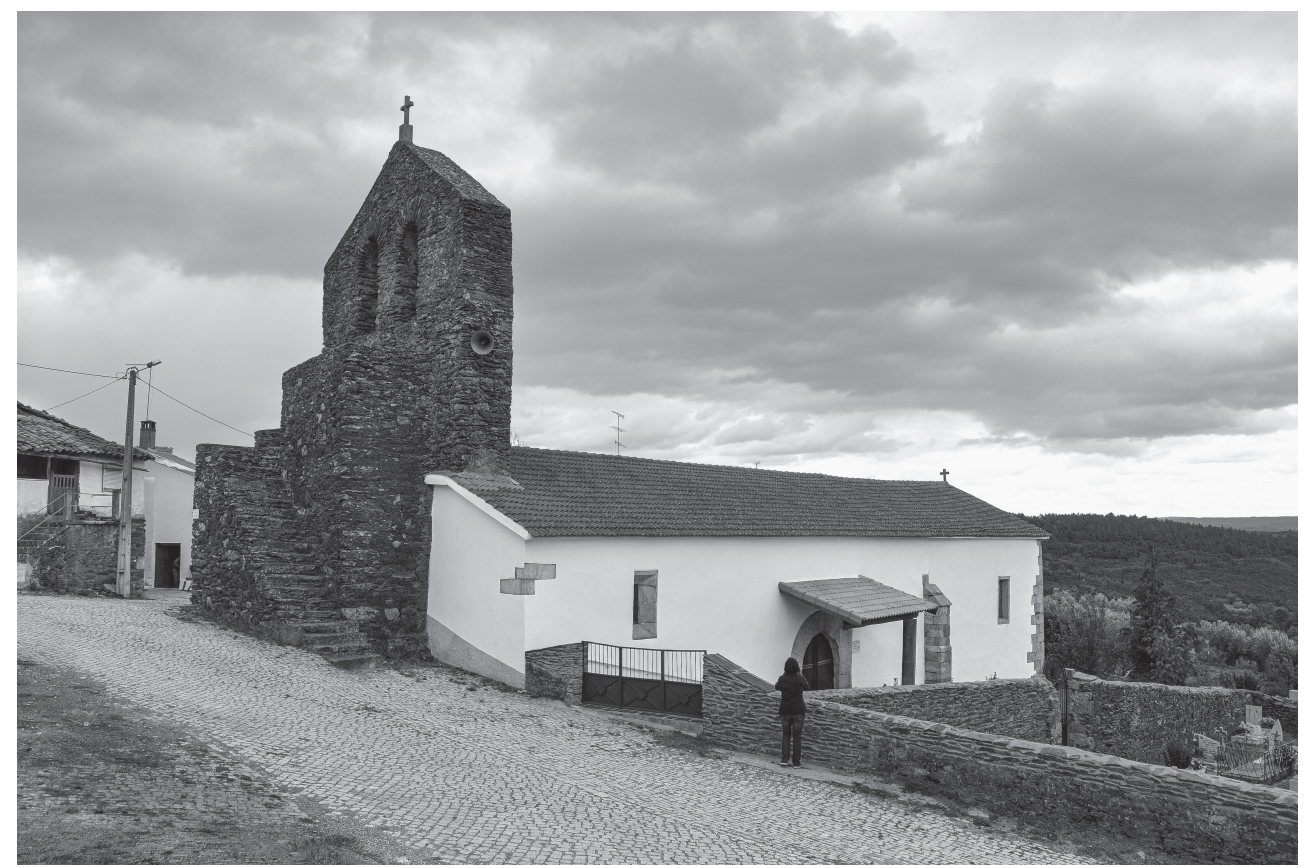

Fig. 3. Lateral sul da igreja matriz

gida por um pequeno alpendre de construção recente. Em frente, e delimitado por um muro, existe um pequeno cemitério. A fachada frontal é quase toda ocupada pelo campanário com escadaria em pedra.

Nos debuxos de Duarte de Armas ${ }^{154}$, desenhados por volta de 1509, este campanário, com dois sinos, surge na mesma fachada oeste e não tinha escadaria em pedra, mas em madeira. Numa outra versão dos desenhos do escudeiro de D. Manuel $\mathrm{I}^{155}$, que foi levada para Madrid, o campanário parece adossado à lateral norte da igreja ${ }^{156}$, com a mesma escadaria em madeira, deixando livre a fachada principal.

As diferenças nos desenhos de Duarte de Armas são visíveis também nas aberturas do templo. Nas vistas que se encontram na Torre do Tombo, nenhuma das fachadas laterais tinha portas, apenas duas janelas na fachada norte (uma na zona da nave e outra na cabeceira) e quatro na fachada sul (três na zona da nave e uma na cabeceira), logo a entrada teria que ser feita pela fachada voltada a oeste. Contudo,

\footnotetext{
${ }^{154}$ ARMAS, 2006.

${ }^{155}$ Estes desenhos fazem parte do códice B que se encontra na Biblioteca Nacional de Madrid e está disponível na Biblioteca Digital Hispánica: bdh.rd.bne.es.

${ }^{156} \mathrm{Na}$ vista oeste do códice B, Duarte de Armas representa a igreja com a orientação atual (este-oeste) cujo campanário parece ocupar a fachada oeste do templo. Já na vista E-NE, Duarte de Armas representa a fachada principal da igreja voltada a leste, parecendo que o campanário se ergue adossado à parede sul. Julgamos que nesta vista, Duarte de Armas inverteu a posição da igreja, não sabemos se por engano ou se por algum motivo de perspetiva.
} 
nos desenhos do códice B vemos não só uma entrada nesta fachada oeste, como uma entrada na lateral sul ${ }^{157}$.

Hoje, como já referimos, o campanário tem uma escadaria adossada de dois lanços, construída em xisto, sendo por isso, uma obra posterior que, ao que parece, inviabilizou a entrada no templo por esta zona. Esta entrada, na fachada principal, está claramente representada pelo escudeiro nos desenhos do códice $B$, sendo sugerida nos desenhos da Torre do Tombo. Ao que tudo indica, existiria também uma porta na fachada sul, que com a inviabilização da entrada a oeste, passou a ser a entrada principal. Não concordamos, pois, com Luís Alexandre Rodrigues, quando diz que:

A ausência da porta principal, no plano voltado a ocidente, é atributo decisivo na moldagem do carácter arquitectónico deste templo, constituindo mesmo uma das suas originalidades. Em consequência, o alçado frontal seria quase integralmente ocupado por uma escadaria que, pela austeridade e desenvolvimento, parece descender da linhagem das que serviam os cubelos das fortificações medievais ${ }^{158}$.

A porta inicial localizar-se-ia na fachada principal, tendo sido, entretanto, entaipada. Esta constatação pode ser confirmada, não só nos desenhos de Duarte de Armas, mas também no facto de, no interior da igreja, se manter uma pia batismal do lado esquerdo da antiga entrada, como era habitual, com indícios de que está no seu lugar de origem. Existe uma outra pia, mais pequena, colocada à direita da porta sul, contudo parece-nos que não será usada como pia batismal ${ }^{159}$. Embora não sejam visíveis vestígios de entaipamentos na parede da fachada principal, pois os alçados estão rebocados, ainda se pode observar, do lado direito, um ressalto que terá servido de suporte a uma escadaria de madeira e a um coro alto, hoje inexistente. Julgamos, pois, que a igreja matriz de Outeiro não constituiu um modelo de originalidade, mas aproxima-se das soluções que vemos em outros templos no concelho de Bragança. A sua primeira fase construtiva poderá ser anterior a 1258, data em que já é referida a igreja de Santa Maria de Outeiro ${ }^{160}$.

Mas os desenhos do escudeiro de D. Manuel I mostram outros pormenores interessantes.

Uma observação mais atenta da igreja permite concluir que o edifício sofreu grandes transformações, possivelmente em diferentes períodos. No que diz respeito à sua planta, agora retangular e de corpo único, terá sofrido ampliações na zona da cabeceira

\footnotetext{
${ }^{157} \mathrm{Na}$ vista E-NE do códice B, a entrada lateral está voltada a norte, mas como dissemos pensamos que esta representação da igreja está invertia.

${ }^{158}$ RODRIGUES, 2001: 554.

${ }^{159}$ A solução mais tardia da escadaria de acesso ao campanário também é indicada na ficha descritiva da igreja do sítio do Património Cultural.

${ }^{160}$ Portugaliae Monumenta Historica. Inquisitiones, 1961: 1285.
} 
e da sacristia, provavelmente no século XVIII ${ }^{161}$. Estas alterações são visíveis nos atuais paramentos, tonando-se mais evidentes quando comparamos o que hoje observamos e a igreja que Duarte de Armas representou nos seus debuxos. Nestes desenhos o templo tinha uma cabeceira bem demarcada da nave e na fachada voltada a norte não vemos nenhum corpo saliente onde hoje se localiza a sacristia. Estas alterações são também visíveis no interior, onde a capela-mor é separada da nave por um arco triunfal de «curvatura levemente curvada» ${ }^{162}$. Ao fundo, o altar em talha dourada parece demasiado pequeno para a parede em pedra nua, com as juntas pintadas de branco. Esta solução terá sido o resultado de obras recentes, talvez da época dos restauros feitos pelo povo da freguesia em 1980-84, como nos informa uma placa na porta lateral. Embora na ficha descritiva sobre esta igreja, apresentada no sítio do Património Cultural, seja referido que os altares datam do século XVIII, da mesma altura das obras de ampliação, parece-nos que o retábulo-mor foi desenhado para um espaço mais pequeno.

Esta pequena igreja matriz perdeu protagonismo no século XVII para a monumental igreja do Santo Cristo de Outeiro, cuja construção foi iniciada em $1698^{163}$ na zona habitacional da "planície». Segundo a lenda, que explica a razão da sua construção, a imagem de Santo Cristo, que se encontrava na capela primitiva, terá começado a suar sangue na primavera daquele ano. A notícia do milagre foi amplamente divulgada, atraindo pessoas de toda a região. Este aumento de peregrinos levou à necessidade de se construir um novo templo, onde a imagem de Santo Cristo pudesse ser exposta com mais solenidade. Iniciou-se então a recolha de donativos tanto em Portugal como em Espanha, criando-se uma confraria para a sua gestão ${ }^{164}$.

A obra apenas ficou concluída na primeira metade do século XVIII, durante o reinado de D. João V. A sua planta interior tem a forma de uma cruz latina, com uma capela-mor pouco profunda totalmente revestida a talha ${ }^{165}$. Na ficha patrimonial que lhe é dedicada no SIPA é descrita nos seguintes termos: «De características arcaizantes em pleno barroco, é um templo grandioso com fachada flanqueada por duas torres.» 166

O corpo central, em cantaria, e rematado por uma balaustrada que une as duas torres, organiza-se em função do portal mainelado (ao qual falta o mainel), a que se sobrepõe um óculo decorado, ambos de tipologia manuelina. Ladeiam estes elementos duas colunas dóricas, que são continuadas por colunas torsas, estas enquadrando nichos de frontão interrompido ${ }^{167}$.

\footnotetext{
${ }^{161}$ Informação retirada do sítio: http://www.patrimoniocultural.pt.

${ }^{162}$ Informação retirada do sítio: http://www.patrimoniocultural.pt.

${ }^{163}$ Monumento classificado como Monumento Nacional pelo Decreto n. ${ }^{\circ} 14615$. PORTUGAL. Ministério da Instrução Pública - Direcção-Geral de Belas Artes, 1927.

164 RODRIGUES, 2001: 554.

165 RODRIGUES, 2001: 555.

166 Informação retirada do sítio: http://www.culturanorte.pt.

${ }^{167}$ Informação retirada do sítio: http://www.patrimoniocultural.pt.
} 


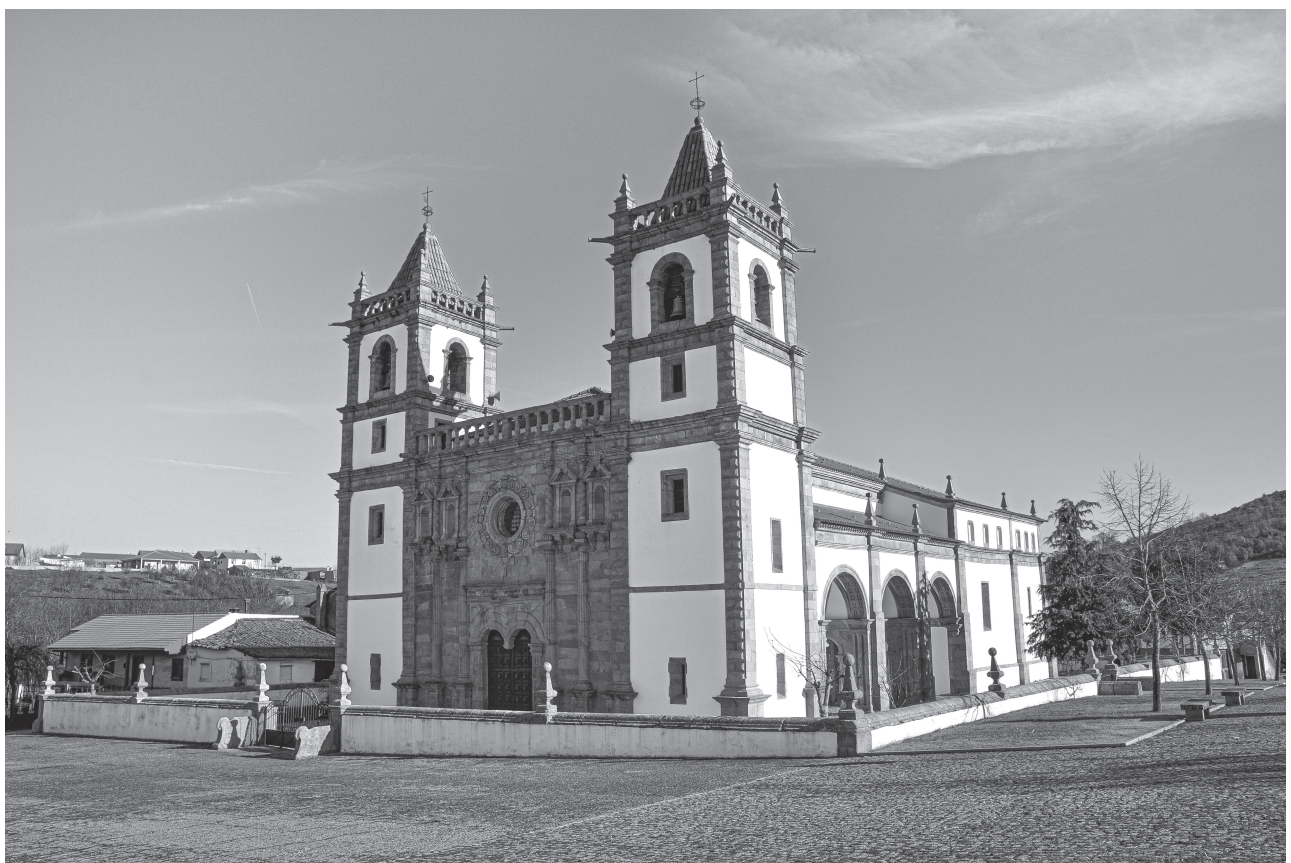

Fig. 4. Igreja de Santo Cristo

Não é conhecido o arquiteto desta obra, «cujo desenho se encontra riscado no chão do templo» ${ }^{168}$. Contudo, sabe-se o nome de alguns mestres pedreiros, registando-se entre eles alguns galegos e leoneses.

De Valladolid veio Damião Bustamante, em 1768, para pintar os 88 quadros que preenchem os caixotões da sacristia. O artista ou artesão, como lhe chama José Ramón Nieto González ${ }^{169}$, segue «as influências seiscentistas, ao invés de adoptar a composição em perspectiva, então em voga» ${ }^{170}$.

O arcaísmo das opções arquitetónicas e artísticas parece ter sido «compensado» pela grandiosidade do templo e poderá refletir o carácter da obra - uma igreja rural, situada no interior, junto à fronteira, longe dos centros urbanos onde a visibilidade e importância exigiam outros cuidados. A igreja de Santo Cristo de Outeiro fez-se grande entre os pequenos.

Embora não tenha sido construída com funções paroquiais, a igreja do Santo Cristo de Outeiro concentra hoje a maioria dos serviços religiosos da povoação, tendo sido alvo de restauro em 2012. Em 2014, foi elevada a basílica menor pela Santa Sé.

\footnotetext{
${ }^{168}$ Informação retirada do sítio: http://www.patrimoniocultural.pt. 169 NIETO GONZÁLEZ, 1983.

${ }^{170}$ Informação retirada do sítio: http://www.patrimoniocultural.pt.
} 
Por último uma referência às ermidas erguidas fora da aldeia ${ }^{171}$. A ermida de Santa Bárbara, a oeste e junto aos caminhos que conduzem às localidades de Parada e Coelhoso, e a ermida de S. Roque, que fica à saída de Outeiro, junto à EN 218-2, que vai para Pinelo. Estas capelinhas já estavam construídas em 1758, aquando da inquirição para as Memórias Paroquiais. Segundo esta fonte, estes pequenos templos teriam sido construídos pelo povo ${ }^{172}$.

Para além dos símbolos religiosos, Outeiro preserva ainda dois importantes testemunhos da sua longa vida concelhia: o pelourinho e a casa da câmara ou antiga cadeia, como é localmente conhecida.

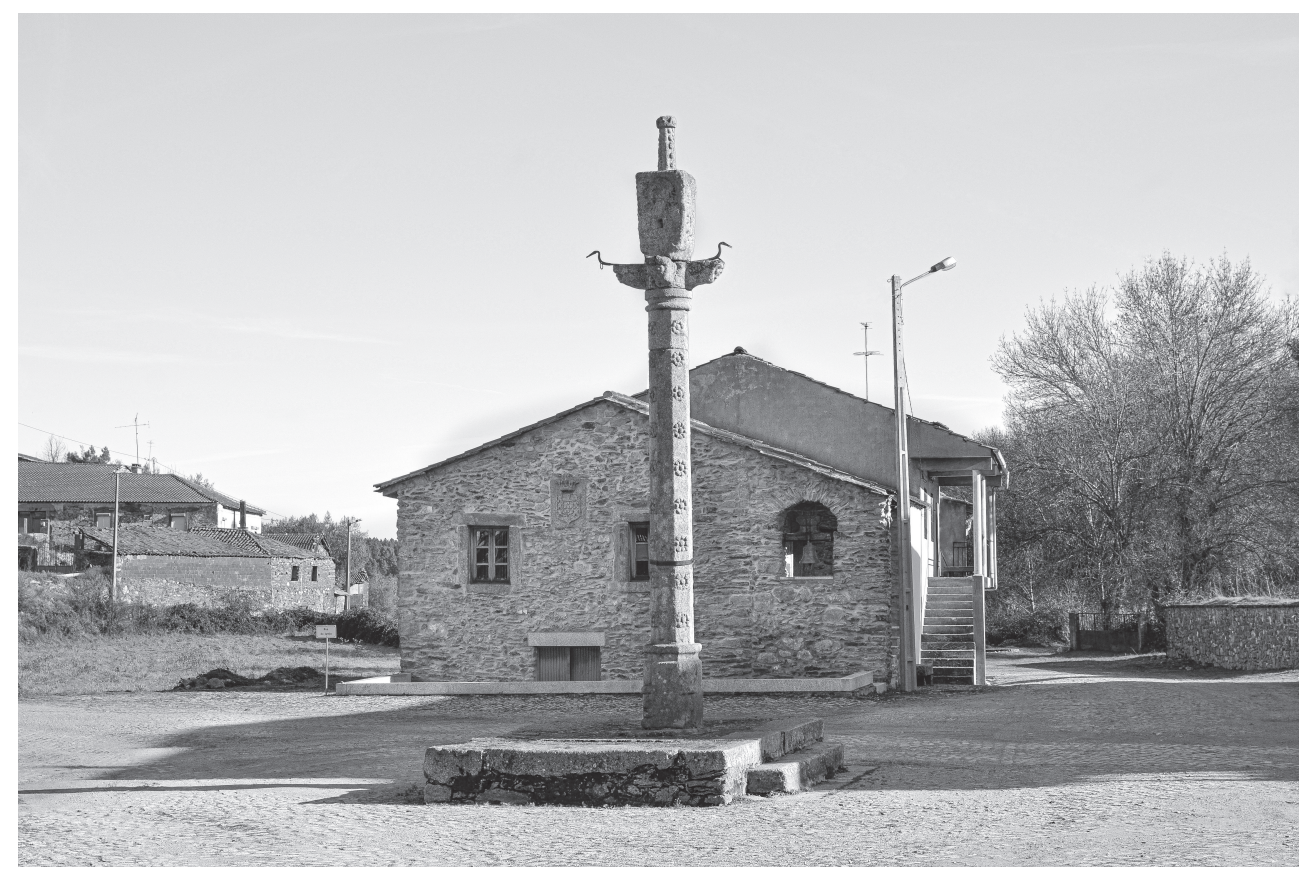

Fig. 5. Pelourinho de Outeiro e a casa da câmara

O pelourinho, erguido em granito no Largo da Cadeia, situa-se numa zona central entre os dois núcleos habitacionais, assumindo-se claramente como elo de união. Este marco da arquitetura civil terá sido construído depois de Outeiro receber o foral de D. Manuel I, em $1514^{173}$.

\footnotetext{
${ }^{171}$ FERNANDES, RODRIGUES, 2004: 187-191.

172 CAPELA et al., 2007: 295, doc. 34.

${ }^{173}$ O pelourinho de Outeiro é classificado como Imóvel de Interesse Público pelo Decreto-lei n. ${ }^{\circ} 23122$. PORTUGAL. Ministério da Instrução Pública — Direcção-Geral do Ensino Superior e das Belas Artes, 1933.
} 
A plataforma onde o pelourinho foi levantado é constituída por uma base quadrangular pouco pronunciada, que teria outrora mais degraus, como nos diz e mostra Eurico de Ataíde Malafaia na sua obra ${ }^{174}$, que seguiremos na íntegra na descrição do pelourinho. Sobre esta plataforma repousa uma base «informe», nas palavras do autor, de onde parte a coluna. Esta tem uma base «oitavada, de pequena altura, com saliências de expressão zoomórfica, em faces alternadas». O fuste, também oitavado, é «decorado com florões em toda a sua altura, e em faces alternadas. No topo existem dois colaretes salientes, redondos, com sulco intermédio, a preceder o capitel». Este último forma uma «cruz grega, com carrancas nas extremidades. Por cima desta peça existiam ferros, de expressão zoomórfica, havendo apenas dois». Esta solução usada no capitel é muito comum nos pelourinhos desta região transmontana ${ }^{175}$. Finalmente o remate que forma um

bloco prismático, profusamente historiado, podendo (ainda) ver-se as armas de Portugal e uma figura eclesiástica, tendo outra ajoelhada junto dela. Este bloco é complementado por um pequeno e irregular cilindro encimado por uma semiesfera bastante tosca. A cerca de um metro e vinte centímetros da base, ofuste apresenta um aro de ferro envolvente, com a respectiva argola ${ }^{176}$.

À descrição que acabamos de transcrever, acrescentamos apenas algumas notas sobre o «bloco prismático» que o autor diz «profusamente historiado». De facto, o monólito tem quatro faces: a principal, voltada sensivelmente a leste, onde vemos um escudo partido, conjugando as armas de Portugal (na metade esquerda) com o símbolo municipal de Outeiro (uma torre ameada, ocupando a metade direita); e, nas outras três faces, figuras humanas. Não sabemos a qual representação o autor se refere quando indica "uma figura eclesiástica, tendo outra ajoelhada junto dela», por isso, descrevemos as figuras como as vemos. No campo voltado a norte foi esculpida uma figura, em alto-relevo, com um «bastão» (ou báculo) na mão, podendo esta corresponder à figura eclesiástica referida pelo autor; no lado oeste, desenhou-se uma figura barbada, com a cabeça coberta e que parece segurar um livro aberto (?); finalmente voltada a sul foi esculpida outra figura barbada com as mãos unidas. Parece, pois, que o pelourinho sintetiza a história de Outeiro cuja jurisdição foi eclesiástica, passando depois, através da Coroa, a ser um município.

Associada ao pelourinho, e a poucos metros deste, está a casa da câmara, que parece ter sofrido algumas alterações. $\mathrm{O}$ edifício, onde hoje funciona um centro

\footnotetext{
174 MALAFAIA, 2005: 307.

${ }^{175}$ Embora com algumas diferenças são exemplo, o pelourinho de Bragança, o de Vimioso, de Freixo de Espada à Cinta, de Mogadouro, Algoso, etc.

${ }^{176}$ MALAFAIA, 2005: 307.
} 
museológico, apresenta planta quadrangular, com piso sobradado e telhado de duas águas. A entrada é feita por um alpendre acrescentado na fachada voltada a sul. Este alpendre é fechado a ocidente, em cuja parede foi aberto um arco sineiro voltado para o pelourinho e a povoação. Na mesma fachada da casa, voltada a oeste, vê-se uma pedra de armas com um escudo de Portugal, obra provavelmente do século XVIII.

O edifício apresenta hoje paredes nuas, construídas em xisto. Porém, a guarnição das portas e das janelas foi talhada em pedra granítica.

Apesar de a casa da câmara ser conhecida localmente como cadeia, pensamos que a ausência de grades nas janelas, a presença do sino e a proximidade ao pelourinho, sugerem que o edifício fosse usado como local de reunião municipal e não como cadeia.

O passar do tempo não se vê apenas nestes testemunhos inequívocos da evolução histórica de Outeiro. Existem outros vestígios que acrescentam memórias ao passado da vila. Percorrendo as suas ruas são visíveis os sinais do progresso, sobretudo nas construções acrescentadas ao longo dos tempos. Este impulso construtor não multiplicou a população, mas foi substituindo as casas rústicas, por vivendas de tijolo e cimento. Surge assim um casario heterogéneo, e um tanto incaracterístico, onde o antigo foi substituído pelo atual, criando vazios e abandonos. Por todo lado, vemos fragmentos de construções passadas, bases de colunas, pias, silhares, tudo em granito.

A par das estradas asfaltadas ainda subsistem os caminhos em terra, por vezes lajeados, que conduzem aos terrenos agricultados fora da povoação.

\subsection{INTEGRAÇÃO DE OUTEIRO NOS DOMÍNIOS DA DIOCESE DE MIRANDA DO DOURO}

Aquando da presúria de Portucale em 868, a diocese de Braga terá ampliado os seus limites para nascente, usurpando os territórios de Aliste, à diocese de Astorga, e para sul, integrando o de Vilariça, pertencente à extinta diocese de Caliábria. Esta expansão foi contestada por Astorga, «que, segundo um documento, de 974, publicado por Florez, tentou recuperar não só a terra de Aliste, mas também apoderar-se de Bragança e Ledra, desde 569, indiscutivelmente, pertencentes a Braga» ${ }^{177}$.

Parece que os intuitos de Astorga foram conseguidos pois, em 1103, S. Geraldo, arcebispo de Braga, "conseguiu que Pascoal II obrigasse o bispo Paio, de Astorga, a devolver à diocese de Braga as terras de Ledra, Aliste e Bragança» ${ }^{178}$. Terá sido a partir desta altura que a região de Bragança e de Outeiro passaram a integrar esta circunscrição eclesiástica, cujos limites o Prof. Doutor José Marques define deste modo:

\footnotetext{
177 MARQUES, 2004-2005: 6-7.

${ }^{178}$ MARQUES, 2004-2005: 7.
} 
a diocese de Braga é limitada pelo mar e por caudalosos cursos de água. Com efeito, da foz do Ave até à do rio Lima é banhada pelo Atlântico, da foz do Lima até Lindoso segue o curso deste rio; de Lindoso, seguia até ao rio Douro, acompanhando, sensivelmente, a actual fronteira portuguesa; na parte leste, depois de entrar no Douro, era este rio que estabelecia a divisória com Castela, continuando a exercer a mesma função, pelo sul, até à foz do Corgo. Aqui, a extrema subia o curso deste rio até à altura de atravessar pela Cumieira até à ponte de Amarante, no Tâmega, que acompanhava até inflectir para o Ave, que atingia em S. Tirso, correndo dali até ao $\operatorname{mar}^{179}$.

Durante a formação do reino de Portugal, a diocese de Braga teve um papel importante no enquadramento e fixação de populações em zonas de fronteira. Lembramos, a este propósito, a autorização dada pelo arcebispo da diocese ao abade do mosteiro de Castro de Avelãs para que atribuísse carta de foro aos moradores de Outeiro, que nos finais do século XIII, estava muito despovoada.

Apesar de Outeiro ter passado para a jurisdição da Coroa em 1290, altura em que recebeu foral de D. Dinis, as aldeias dos seus termos continuaram a pagar foros ao mosteiro de Castro de Avelãs. Num documento apresentado pelo Abade de Baçal $^{180}$, datado de 1455, o duque de Bragança, D. Afonso, e o abade do mosteiro de Castro de Avelãs, acordam uma sentença sobre os foros que as aldeias do «Lombo dos Carvalhais» teriam que pagar ao mosteiro. Segundo o documento, as aldeias do «Lombo dos Carvalhais» pertenceriam ao termo de Outeiro, e seriam as localidades de Rio Frio, Milhão, Paço e Paradinha.

Em 1545 dá-se a extinção do mosteiro de Castro de Avelãs e cria-se a diocese de Miranda do Douro. Este duplo acontecimento vem no seguimento da política de D. João III, que decide criar novas dioceses, "desmembrando-as das dioceses que dispunham de um território demasiado grande. Foi neste contexto que se procedeu à erecção da diocese de Miranda, a partir do arcebispado de Braga» ${ }^{181}$.

No mesmo ano da instituição da diocese, Miranda recebe estatuto de cidade, e a Sé é dotada do seu bispo e dignidades. O mosteiro de Castro de Avelãs é então extinto para que as suas rendas sirvam de sustento ao cabido ${ }^{182}$. Será assim, que a comarca de Outeiro passará a fazer parte da administração eclesiástica da diocese de Miranda. A bula da criação da Sé de Miranda, com data de 22 de maio de 1545, indica quais as rendas que passam a pertencer à nova diocese:

\footnotetext{
179 MARQUES, 2004-2005: 5.

${ }^{180}$ ALVES, 2000: IV, 471-474.

${ }^{181}$ AFONSO, 2002: 111.

${ }^{182}$ AFONSO, 2002: 111.
} 
Miranda proedictam et civitatem noncupatam de Bragantia, et de Vinhaes, et de Outeiro, nec non de Monforte de rio Livre, et de Vimioso, ac de Chaves, et de Monte Alegre dictae Docesis oppida cum omnibus, et singulis eorum terminis, et territoriis, ac dilectis filiis clero, populo, et personis, nec non monasteriis, Ecclesiis, et piis locis, ac beneficiis Ecclesiasticis cum cura, et sone cura secularibus, et ordinum quorumcumque regularibus ab aedem Diocesi Bracarensi Apostolica auctoritate tenore proesentium perpetuo separamus, et dismembramus ${ }^{183}$.

A 14 de julho do mesmo ano, D. João III, escreve «ao corregedor de Miranda participando-lhe que D. Toríbio ia tomar posse da diocese devendo, por isso, auxilia-lo no que fosse mister ${ }^{184}$. Na carta, dirigida não só ao corregedor mas também ao ouvidor do duque de Bragança, a quem pertenciam as terras de Bragança e Outeiro, são mais uma vez referidos os termos que farão parte da diocese:

Eu El-Rey faço saber a vos corregedor da comarca de Miranda e ao ouvidor do duque de Bragança meu muito amado e presado sobrinho e a quaisquer outros corregedores juizes e justiças a que este for mostrado e o conhecimento pertencer que eu pedi ao Santo Padre que criasse e alevantasse em See cathredal a egreja de Nossa Senhora da villa de Miranda e a apartasse da diocese do arcebispado de Bragua com toda a jurisdição episcopal fruitos e rendas e dereitos que o arcebispado de Braga tinha os logares seguintes a saber: a dita villa de Miranda e seu termo com as egrejas da dita villa e termo e a cidade de Bragança e seu termo com as egrejas e moesteiros da dita cidade e seu termo e a villa de Vinhaaes e seu termo com suas egrejas e a villa de Outeiro e seu termo e a villa de Monforte de Rio Livre e seu termo com suas egrejas e a villa do Vimioso e seu termo e a villa de Chaves e seu termo com as suas egrejas e os conceder por diocese e bispado ha dita Egreja cathedral de Nossa Senhora de Miranda ${ }^{185}$.

Em 28 de agosto de 1545, D. João III volta a escrever ao corregedor e ouvidor do duque de Bragança, dando instruções de como deve ser passado o alvará que permitia a D. Toríbio Lopes, bispo de Miranda, tomar posse dos foros para a diocese. Nesta carta, o monarca especifica com mais detalhe as vilas e concelhos que farão parte da jurisdição da diocese de Miranda. Assim, para além das referidas no documento anterior, faz-se menção aos:

\footnotetext{
183 ALVES, 2000: III, 9-14.

${ }^{184}$ ALVES, 2000: III, 17-18.

${ }^{185}$ ALVES, 2000: III, 17-19.
} 
concelhos d'Algoso e Penarroyas, Chacim, Nuedosa [sic], Nozelos, Sofulte [sic], Val de Asnas, Cortiços, Torre Dona Chama, Bemposta, Azinhoso, villa de Mirandela com os termos dos ditos concelhos e villas e suas igrejas e coutos e cameras que nos ditos logares e seu termos e limites estam e jazem que pertenciam ate ora aos arcebispos e see de Bragua e concedese as ditas villas e lugares por diocese e bispado a dita Igreja cathedral de Nossa Senhora de Miranda e lhe apricasse as ditas jurdições rendas e direitos, coutos e cameras pera que o bispo que pello tempo for da dita igreja de Miranda tenhas as ditas jurdições em eles e aja todos os direitos e rendas que os arcebispos de Bragua ate ora teveram e ouveram ${ }^{186}$.

Em claro prejuízo para a diocese de Braga, a diocese de Miranda fica assim com a jurisdição eclesiástica sobre Miranda, Bragança, Vinhais, Outeiro, Monforte de Rio Livre, Vimioso, Chaves, Algoso, Penas Roias, Chacim, Nuedosa, Nozelos, Sofulte, Val de Asnas, Cortiços, Torre de Dona Chama, Bemposta, Azinhoso e Mirandela. Embora não seja referida nas cartas do monarca, a bula papal parece incluir ainda na diocese de Miranda as rendas de Montalegre ${ }^{187}$.

Ainda sobre estes documentos da criação da diocese de Miranda, é curioso reparar que Outeiro é referido apenas como Outeiro e não como Outeiro de Miranda.

Foi em 1780 que Miranda do Douro perdeu a sede do bispado para Bragança, passando a designar-se de Bragança e de Miranda ${ }^{188}$. Terá sido depois desta alteração da sede, e já em 1858, que no mapa das côngruas, a paróquia de Outeiro surge com o orago de Nossa Senhora da Assunção e com 203 fogos ${ }^{189}$.

\footnotetext{
${ }^{186}$ ALVES, 2000: III, 18-19.

${ }^{187}$ ALVES, 2000: III, 10.

${ }^{188}$ MENDONÇA, 1995: 252.

${ }^{189}$ ALVES, 2000: I, 395.
} 


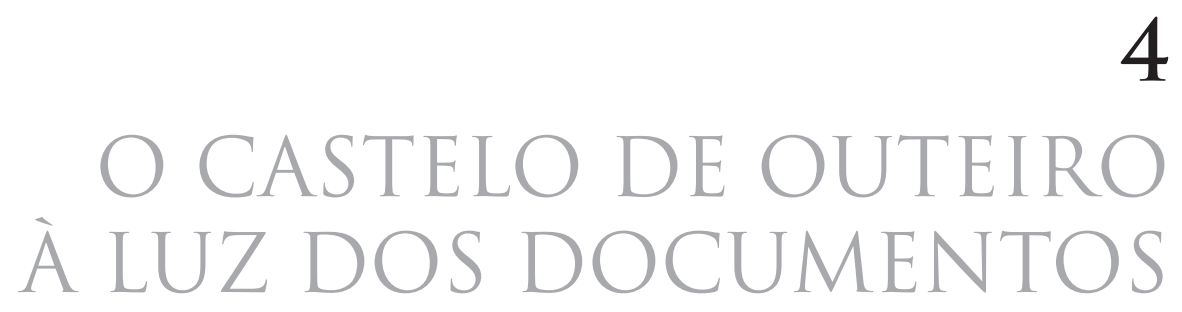



No período de formação do reino de Portugal, os primeiros monarcas empenharam-se numa ação concertada com o intuito de afirmar e reforçar a sua soberania nas zonas próximas de Leão através de alianças, doações e conceção de forais que enquadrassem e fixassem populações nessas regiões. Este reforço do povoamento das zonas fronteiriças, onde a demografia há muito sofria de uma crónica rarefação, beneficiou, no caso transmontano, da ação do mosteiro de Castro de Avelãs, que protegido pela linhagem dos Braganções promoveu a ocupação de uma faixa considerável de território na zona de Bragança.

É neste cenário de consolidação do poder real que Outeiro nos surge na documentação, primeiro em 1194 como uma localidade indefinida e depois, em 1258, como uma paróquia dependente do cenóbio beneditino. Deste mosteiro receberá privilégios para que a população se fixasse e cultivasse os seus campos, num claro esforço de povoamento da região.

Será nos finais do século XIII, sobretudo «a partir da década de 1260, que a "questão da delimitação do reino" se afirmou como preocupação patente na documentação de produção régia» ${ }^{190}$. Esta preocupação traduziu-se em ações políticas, nomeadamente durante o reinado de D. Dinis, como a aquisição e controlo de vastas zonas fronteiriças, que possibilitariam a consolidação e a defesa do reino. À luz desta conjuntura Outeiro passará para os domínios da Coroa em 1290 e será, mais uma vez, beneficiado com carta de foro, que incentivava o crescimento populacional.

Tendo como base a documentação, e no que se refere a Outeiro, a política de clarificação e controlo fronteiriços, terá passado primeiro pela fixação e integração administrativa das populações, e só depois pelo reforço desta faixa de território com uma estrutura militar que garantisse a defesa da terra e das suas povoações. Como o desenvolvimento da povoação de Outeiro já foi abordado no capítulo anterior, cabe agora analisar a construção e evolução do seu castelo, que obviamente está associado à história da vila.

O estudo do castelo de Outeiro iniciará com a análise documental, onde as referências à fortaleza surgem muitas vezes associadas a problemas de povoamento e ao desenvolvimento da povoação. A existência de uma estrutura militar e a necessidade da sua manutenção obrigou os monarcas a alargar os termos do concelho rural, garantindo assim, população suficiente para vigiar e manter a praça.

O castelo de Outeiro integra uma primeira linha de defesa da fronteira oriental de Trás-os-Montes, controlando a entrada e a passagem dos exércitos inimigos no planalto que se estendia entre Vimioso e Bragança. Esteve ativo entre os séculos XIV e XVII, tendo participado em alguns conflitos que envolveram a Coroa portuguesa.

\footnotetext{
${ }^{190}$ SERRÃO, MARQUES, dir., 1996: 145.
} 
Erguido por vontade régia, com o intuito de defender o reino, o castelo de Outeiro conheceu vários alcaides nomeados pela Coroa. Durante o reinado de D. Fernando passará para o domínio senhorial, acabando no século XV por integrar os domínios da Casa de Bragança.

\subsection{AS REFERÊNCIAS DOCUMENTAIS AO CASTELO DE OUTEIRO}

Entre os documentos consultados não encontramos nenhuma referência à construção do castelo de Outeiro. A primeira notícia com referência explícita a uma construção defensiva surge numa carta com data de 28 de agosto de $1355^{191}$. Neste documento os moradores de Outeiro veem rejeitada a sua pretensão de aumentar os termos do concelho e fazerem vila cercada. A menção inequívoca à existência de um castelo em Outeiro só aparece num diploma com data de 1361, seis anos depois do pedido dos moradores para fazerem vila cercada. Neste último documento D. Pedro I entrega a fortaleza a João Rodrigues de Bastos para que este lhe faça menagem ${ }^{192}$.

Com base nas fontes documentais, o castelo de Outeiro terá sido construído entre 1355 e 1361, isto é, entre os finais do reinado de D. Afonso IV e inícios do reinado de D. Pedro I. A ser assim, esta fortaleza terá sido a construção mais recente da linha de defesa transmontana, erguida numa altura em que outras fortalezas da região teriam já recebido reformas góticas, passando a adotar uma lógica de defesa ativa.

Alguns autores do século XX, apesar de não fundamentarem as suas afirmações ou revelarem as suas fontes, atribuem a construção do castelo de Outeiro a D. Dinis. Pensamos que se basearam em autores precedentes, veiculando as suas opiniões, senão vejamos.

Na sua obra sobre os pelourinhos de Trás-os-Montes, Sebastião da Silva Leal refere o santuário de Nossa Senhora da Ribeira, erguido na aldeia de Quintanilha, junto ao rio Maçãs e à fronteira com Espanha. Escreve o autor que, segundo a lenda, a imagem da Senhora terá aparecido a uma pastorinha, muda de nascença, e que desde então, teria passado a falar, contando a toda a gente o sucedido. Convencidos que tinham sido agraciados com um milagre, os povos daquele sítio construíram uma ermida em homenagem a Nossa Senhora. Este acontecimento ter-se-á passado no reinado de D. Afonso III, entre 1250 e 1270 . Isto porque, segundo o mesmo autor, quando D. Dinis casa com D. Isabel de Aragão, em julho de 1282, a ermida já existia. Terá sido durante a viagem para Portugal, que a futura Rainha Santa, ao atravessar a fronteira em Quintanilha, viu muitos devotos na dita ermida e, inteirando-se dos milagres da Santa Senhora, terá prometido a construção de uma nova capela que

\footnotetext{
191 Trás-os-Montes Medieval e Moderno. Fontes Documentais. Séc. XIV, 2003: doc. 36.

192 Chancelarias Portuguesas: D. Pedro I (1357-1367), 1984: 268.
} 
melhor acolhesse os romeiros. Depois do casamento com D. Dinis em Trancoso, e já regressados a Lisboa, a rainha D. Isabel terá comunicado «a D. Diniz, seu marido, a sua ideia, que tencionava fazer erigir um castello no monte sobranceiro por motivo da sua forte posição e por ficar na extremidade dos seus domínios, e o rei anuiu aos desejos da rainha e mandou logo construir a fortaleza e ampliar a referida ermida, que é a que ainda existe, sendo um templo bastante vasto» ${ }^{193}$.

Sebastião da Silva Leal refere a construção de um castelo num monte sobranceiro à capela de Nossa Senhora da Ribeira. Ora Outeiro dista mais de $6 \mathrm{~km}$ do local de romaria. Este facto não impediu outros autores de repetirem a mesma ideia, assumindo a crista quartzítica de Outeiro como o lugar escolhido para a edificação do castelo, cuja obra teria sido promovida por D. Dinis numa data próxima a $1282^{194}$.

Numa obra relativamente recente, José Peixoto Pinto da Mota aborda a identidade histórica de algumas aldeias transmontanas, onde incluiu Outeiro. No texto refere a questão da origem do castelo, mas não o associa à capela da Nossa Senhora da Ribeira. Com base em documentos, como o escambo de «Outer de Muas» de 1290, acordado entre D. Dinis e o mosteiro de Castro de Avelãs, em que a aldeia passa para a alçada da Coroa, e no foral dado, três meses depois, pelo mesmo monarca à povoação, o autor escreve que, com estas diligências, estavam reunidas as condições para dotar "a "vila" de uma fortificação defensiva, construída no cimo do outeiro, importante ponto de vigia sobre terras de Leão» ${ }^{195}$. Numa nota de rodapé, relativamente a esta ideia, o autor concluiu que «nenhum dos documentos compulsados faz referência ao castelo», contudo, «tudo leva a crer que fosse D. Dinis que o mandasse erguer, no cimo do outeiro, depois de efectuado o escambo e lhe ter outorgado a carta de foro, aumentando, assim, a linha de defesa da fronteira» ${ }^{196}$.

Embora, tal como o autor anteriormente citado, não tenhamos encontrado documentos que corroborem a hipótese de o castelo de Outeiro ter sido erguido durante o reinado de D. Dinis, parece-nos legítimo colocar esta questão, justificando-a com a aquisição da aldeia de Outeiro através do escambo e da atribuição do foral. Esta ação enquadra-se na política dionisina de controlo da fronteira, promovendo o seu povoamento e garantindo a defesa do reino. Quase encostado à fronteira com Castela, Outeiro era de facto um ponto de vigia privilegiado, reunindo condições para

\footnotetext{
${ }^{193}$ LEAL, 1910: 154.

194 Outros autores, como FELGUEIRAS, 1968: 7 ou GARRIDO, 1981: 110, associam a construção do castelo de Outeiro à construção da ermida da Nossa Senhora da Ribeira, em Quintanilha, sendo ambas obras da responsabilidade de D. Dinis que as mandou erguer a partir do ano de 1282. FREITAS, 2009: 128, recuperará esta tese, reforçando que o castelo serviria para proteger o santuário. Já PERES, 1969: 219 e VERDELHO, 2000: 71, apenas referem a construção do mesmo castelo como obra de D. Dinis, sem mencionarem a capela nem indicarem nenhuma data para a sua edificação. Finalmente, FELGUEIRAS, 1968: 9 repete que alguns autores atribuem a construção do castelo de Outeiro a D. Dinis, mas que o Abade de Baçal não concorda com esta afirmação. 195 MOTA, 2004-2005: 64.

${ }^{196}$ MOTA, 2004-2005: 64, nota de rodapé n. ${ }^{\circ} 19$.
} 
receber uma fortificação que complementasse a linha de defesa transmontana. Além da vertente militar, a construção de um castelo naquela zona tinha um papel importante na afirmação do poder da Coroa em detrimento dos poderes senhoriais, que durante mais de um século dominaram Trás-os-Montes. Símbolo da autoridade régia, representava o poder central, que se fazia presente nestas regiões remotas através de laços de vassalagem entre o monarca e os seus súbditos.

Para além destes elementos, que não confirmam explicitamente D. Dinis como o mandante da construção do castelo de Outeiro, podemos indicar outros indícios que nos levam a sugerir que a fortaleza poderia já existir num período anterior a 1361 .

O primeiro indício remete-nos novamente para o diploma de 1355, onde os moradores da vila pediam que os termos do concelho fossem alargados e que se fizesse «vila cercada no dicto logo d'Outeyro» ${ }^{197}$. No documento não se refere a existência de um castelo, mas a pretensão em fazer vila cercada no lugar do Outeiro, isto é, a população não pretendia cercar a aldeia existente, mas sim cercar o cabeço a que chamavam Outeiro, e lá construírem casas. Este desejo de proteção faria mais sentido se no mesmo lugar existisse já uma estrutura defensiva. Aliás, em 1361 o castelo de Miranda é mencionado na carta em que D. Pedro I entrega a fortaleza a João Rodrigues Bastos ${ }^{198}$, não se fazendo referência a nenhuma cerca. Esta só será novamente mencionada em 1414, num outro documento em que D. João I manda «fazer huũ cerco de villa a par do nosso castello d outeyro de mjranda a qual cerca he Ja fecta boa parte» ${ }^{199}$. Parece-nos pertinente questionar o facto de em 1355 não ter sido autorizada a construção de uma simples cerca no outeiro, sem outra estrutura, e que passados apenas seis anos esteja já construído um castelo, com alcaide atribuído e não se fale na cerca, que apenas voltará a ser referida novamente 53 anos depois, encontrando-se ainda em fase de construção. Este facto aponta para que tenha sido construído primeiro um castelo e só depois se tenha construído a cerca. Contudo mantem-se a dúvida sobre a data da construção da fortaleza.

Outro dos indícios encontra-se patente no foral de D. Manuel I, com data de 11 de novembro de 1514, onde, como já tivemos oportunidade de expor no capítulo anterior, se faz referência ao foral de D. Dinis, de 1290. No texto manuelino podemos ler a seguinte frase: «Foy primeiramente Imposto nome douteiro dasnas ao dicto lugar que se ora chama outeiro de miranda. despois que do termo de miranda foi tirado certa parte pera o darem por termo ao dito castello.» ${ }^{200}$ Ao lermos este trecho do texto manuelino, ficamos com a impressão que o monarca pudesse estar a afirmar que, em 1290, já existia um castelo. Daí que se tenham tirado terras a Miranda, para as

\footnotetext{
197 Trás-os-Montes Medieval e Moderno. Fontes Documentais. Séc. XIV, 2003: doc. 36.

198 Chancelarias Portuguesas: D. Pedro I (1357-1367), 1984: 268.

${ }^{199}$ Chancelarias Portuguesas: D. João I (1410-1418), 2006: vol. III, tomo 3, 173.

${ }^{200}$ Forais Manuelinos do Reino de Portugal e do Algarve: Trás-os-Montes, 1961: 57.
} 
dar como termo ao castelo de Outeiro. Notamos, contudo, que, no foral de D. Dinis, não se faz referência aos termos de Outeiro de Miranda, facto que não impede que tenham sido estabelecidos. Com base nos documentos, só se refere alargamento de termos para Outeiro no reinado de D. João I, em 1387, em prejuízo justamente de Miranda. Nesta data o castelo já estava construído e, supostamente, já se tinha visto envolvido num conflito, em 1369. Os motivos do alargamento dos termos de Outeiro, na segunda metade do século XIV, deveriam prender-se com o financiamento de restauros na estrutura defensiva e garantir efetivos para a praça militar.

A ideia de que o castelo foi construído antes de 1361, ganha outros argumentos quando olhamos para os desenhos do Duarte de Armas e observamos atentamente

Tabela 2. Cronologia do castelo de Outeiro segundo os documentos

\begin{tabular}{|c|c|c|}
\hline $\begin{array}{l}\text { 1355, } \\
\text { agosto, } 28\end{array}$ & $\begin{array}{l}\text { O corregedor e vedor de Trás-os-Montes rejeita o pedido dos moradores } \\
\text { de Outeiro de Miranda, que pretendiam fazer vila cercada no lugar } \\
\text { chamado Outeiro. }\end{array}$ & $\begin{array}{l}\text { Trás-os-Montes Medieval e } \\
\text { Moderno. Fontes Documentais. } \\
\text { Séc. XIV, 2003: doc. } 36 .\end{array}$ \\
\hline 1361 & $\begin{array}{l}\text { Primeira referência ao castelo. D. Pedro I entrega o castelo de Outeiro } \\
\text { de Miranda a João Rodrigues de Basto. }\end{array}$ & $\begin{array}{l}\text { Chancelarias Portuguesas: } \\
\text { D. Pedrol (1357-1367), 1984: } 268 .\end{array}$ \\
\hline 1369 & $\begin{array}{l}\text { D. Henrique II de Castela invade o norte de Portugal, tomando as } \\
\text { praças de Vinhais, Bragança e Outeiro de Miranda. }\end{array}$ & LOPES, 1966: 96. \\
\hline $\begin{array}{l}\text { 1414, } \\
\text { julho }\end{array}$ & $\begin{array}{l}\text { D. João I dá autorização aos moradores de Outeiro de Miranda para } \\
\text { construírem a cerca da vila e lá erguerem casas. }\end{array}$ & $\begin{array}{l}\text { Chancelarias Portuguesas: } \\
\text { D. Joãol(1410-1418), 2006: vol. III, } \\
\text { tomo 3, } 173 .\end{array}$ \\
\hline $\begin{array}{l}\text { 1418, } \\
\text { fevereiro }\end{array}$ & $\begin{array}{l}\text { D. João I alarga substancialmente os termos de Outeiro de Miranda } \\
\text { e manda fazer obras no seu castelo. }\end{array}$ & $\begin{array}{l}\text { Chancelarias Portuguesas: } \\
\text { D. Joãol(1410-1425), 2006: vol. IV, } \\
\text { tomo 1, 26-27. }\end{array}$ \\
\hline c. 1508 & $\begin{array}{l}\text { Os moradores de Outeiro de Miranda reconstruíram parte do muro } \\
\text { da vila que tinha ruído. }\end{array}$ & ALVES, 2000: VIII, 148-156. \\
\hline 1530 & $\begin{array}{l}\text { No recenseamento da povoação de Outeiro, diz-se que a vila tem } \\
\text { um bom castelo. }\end{array}$ & FREIRE, 1909: 265. \\
\hline 1538 & $\begin{array}{l}\text { Inquirição sobre os termos de Outeiro e sobre a sua delimitação com } \\
\text { o reino de Castela. }\end{array}$ & $\begin{array}{l}\text { Demarcações de Fronteira: lugares } \\
\text { de Trás-os-Montes e Entre-Douro- } \\
\text { e-Minho, 2003: III, 59-63. }\end{array}$ \\
\hline 1642 & $\begin{array}{l}\text { Aquisição de peças de artilharia para as praças de Bragança, Monforte } \\
\text { de Rio Livre e Outeiro. }\end{array}$ & ALVES, 2000: XI, 124-125. \\
\hline 1646 & Uma incursão espanhola destrói a vila de Outeiro. & ALVES, 2000: I, 90. \\
\hline 1758 & $\begin{array}{l}\text { Nas inquirições para as Memórias Paroquiais é dito que o castelo } \\
\text { tem duas torres, casas para morarem os governadores e soldados e } \\
\text { uma capela de invocação a Santa Luzia. Acrescenta-se que as casas } \\
\text { e as muralhas estão em ruínas, pois há anos que não habitam lá } \\
\text { governadores. Informa-se ainda que no terramoto } 1755 \text { caiu uma ameia, } \\
\text { não se tendo reparado o estrago. A praça não tinha peças de artilharia } \\
\text { nem munições, sendo visitada a cada dois meses por uma esquadra } \\
\text { de infantes da praça de Bragança, com o seu sargento e alferes. }\end{array}$ & CAPELA et al., 2007: 294-297. \\
\hline 1762 & $\begin{array}{l}\text { Destruição do castelo por tropas espanholas, tendo-se queimado as } \\
\text { madeiras e portas e minado as muralhas. }\end{array}$ & MANSO PORTO, 1999: XXXVII. \\
\hline 1886 & Demarcação da fronteira entre Portugal e Espanha. & $\begin{array}{l}\text { As Gavetas da Torre do Tombo, } \\
\text { 1977: XII, 246-290. }\end{array}$ \\
\hline 1993 & Obras de consolidação de partes da muralha. & $\begin{array}{l}\text { Direção-Geral do Património } \\
\text { Cultural: http://www. } \\
\text { patrimoniocultural.pt. }\end{array}$ \\
\hline
\end{tabular}

Fonte: Elaboração própria 
a planta que ele nos deixou do castelo de Outeiro. Dissecando cada elemento da estrutura, desenhada por volta de 1509, rapidamente percebemos que o castelo não é uma construção de plano único, mas que terá sofrido alterações ao longo da sua existência. A verdade é que a planta mostra soluções de arquiteturas anteriores a 1361. Esta questão será abordada no próximo capítulo, onde analisaremos em pormenor os aspetos estruturais do castelo de Outeiro, partindo exatamente dos debuxos do escudeiro de D. Manuel I. Por ora, admitimos que podem não estar esgotadas todas as possibilidades documentais, podendo existir, eventualmente, outras informações sobre a construção do castelo de Outeiro. Contudo, não devemos ficar reféns da história escrita pois, muitas vezes, a investigação arqueológica acrescenta outras interrogações e outras hipóteses.

\subsubsection{A preocupação com o povoamento da vila e a manutenção do castelo}

A questão do povoamento é uma ideia transversal neste estudo e já muitas vezes mencionada. Neste ponto abordaremos a problemática do povoamento, na medida em que ela se relaciona diretamente com a manutenção e a gestão do castelo.

Como a nossa base de análise é a documentação, e nela o castelo surge mencionado a partir de 1361, partiremos deste ponto para analisarmos a evolução demográfica do concelho de Outeiro.

O problema do povoamento acompanhou sempre a história de Portugal, sobretudo em regiões como Trás-os-Montes. No século XIV este problema agudizou-se, sobretudo nos reinados de D. Afonso IV e depois com D. Fernando, período em que as epidemias, os maus anos agrícolas e a guerra dizimaram muita gente, arrasaram a economia e criaram insegurança nas populações. A morte de D. Fernando, e a crise dinástica que se seguiu, trouxe mais instabilidade e guerra, dividindo o reino entre apoiantes do Mestre de Avis e partidários dos reis de Castela. Por estes últimos tomaram voz as principais praças transmontanas, entre elas Bragança, Outeiro e Miranda do Douro. Será ao longo do ano de 1386 que D. João I toma definitivamente estas praças ${ }^{201}$, confirmando em novembro de 1387 "ao concelho e homens boons d outeiro de mjranda todos seus priujllegios foros liberdades e boons custumes de que sempre husarom» ${ }^{202}$. Esta confirmação surge como um incentivo à manutenção das populações nas suas aldeias, apesar da constante ameaça castelhana.

Em 1414 o mesmo monarca, D. João I, autoriza os moradores de Outeiro de Miranda e outros que sejam de fora, a construírem casas dentro da cerca da vila, junto ao castelo, conforme o desejo da população. Neste sentido o monarca incumbe

\footnotetext{
${ }^{201}$ COELHO, 2008: 122-123.

202 Chancelarias Portuguesas: D. João I (1384-1388), 2005: vol. I, tomo 3, 229.
} 
o «dom abade de crasto d auellaãs» de repartir «os chaãos de dentro da dicta cerca aos do dicto lugar e de fora delle que hi quiserem fazer casas e morar e pobrar em ellas Repartindo lhes os chaãos segundo ujr que cada huũ merece» ${ }^{203}$. E porque os moradores temiam que lhes fosse cobrado um foro que não pudessem pagar, o monarca acrescenta «que estes chaãos de aos que assy qujserem morar e pobrar em o dicto lugar pera sempre pera eles e pera todos seus herdeiros e descendentes que depos eles vierem sem pagando a nos e aos reis que despois de nos vierem nemhũa cousa das dictas casas» ${ }^{204}$.

Passados quatro anos desta autorização, em fevereiro de 1418, D. João I aumenta os termos de Outeiro de Miranda explicando a razão da sua decisão:

nos auemos por certa enformaçam que o nosso castello d outeiro de miranda he muy despouorado E esto por o dicto lugar teer muy pequeno termo e de muy poucas gentes E porque em os tempos das guerras nom he bem defensado per mjngoa de gentes que em elle nom há pera o auerem de defender e guardar $E$ a nos conuem de olharmos por elle e o proueermos de moor termo e mais gentes pera nosso serujço e guarda do dicto lugar ${ }^{205}$.

Parece não haver dúvidas que Outeiro de Miranda se encontrava exangue de gente e a sua fortaleza decadente. D. João I reclama para si a responsabilidade na resolução desta situação, aumentando os termos e consequentemente as rendas do concelho, incentivando a recuperação do castelo e da própria vila.

Contudo, em 1421, três anos depois de ter aumentado os termos de Outeiro de Miranda, o monarca da Boa Memória, volta a escrever preocupado com as notícias que lhe chegam desta região. Diz D. João I que «o Jffante dom pedro meu filho nos enujou dizer que a nossa villa d outeiro de mjranda he muy despobrada per aazo das guerras e pestilências en tanto que hi nom ha gente que a possa uellar nem roldar e defender vijndo guerra» ${ }^{206}$. Novamente a questão do despovoamento, apontando-se neste diploma as suas causas: a peste e a guerra. Apesar de se ter assinado um tratado de paz com Castela em 1411, a Coroa continuou a recrutar homens para as conquistas e explorações além-mar, nomeadamente para Ceuta. Talvez por esta e outras razões, faltasse gente que velasse e defendesse a fronteira transmontana.

Procurando uma solução para este mal crónico, o infante D. Pedro pede autorização ao pai para dar «lugar e licença a cinquoenta homjziados que pudessem viuer

\footnotetext{
${ }^{203}$ Chancelarias Portuguesas: D. João I (1410-1418), 2006: vol. III, tomo 3, 173.

${ }^{204}$ Chancelarias Portuguesas: D. João I (1410-1418), 2006: vol. III, tomo 3, 173.

${ }^{205}$ Chancelarias Portuguesas: D. João I (1410-1425), 2006: vol. IV, tomo 1, 26-27.

${ }^{206}$ Chancelarias Portuguesas: D. João I (1410-1418), 2006: vol. III, tomo 3, 139.
} 
e star coutados no dicto logo» ${ }^{207}$. O monarca acedeu ao pedido do filho e autorizou 50 homiziados, que não tivessem sido condenados pelos crimes de aleive ou traição, a viverem na vila sob as mesmas condições do couto de homiziados do Sabugal. E para que não houvesse dúvidas sobre estas condições, determina que os homiziados que vivessem em Outeiro de Miranda, pudessem ausentar-se da vila dois meses por ano para procurarem mantimentos dentro do reino, acrescentando:

E mandamos que per esta licença eles possam andar per nossos regnos per onde lhes prouuer emquanto lhes a dicta licença // durar que nom seiam presos nem thes sei afecto nemhuũ outro desaguisado Comtanto que eles nom entrem nos lugares onde fizeram os dictos malefícios e em seus termos ${ }^{208}$.

Depois da criação do couto de homiziados em Outeiro de Miranda, não encontramos outros documentos com indicações sobre a população do concelho até 1527. Contudo, sabemos que o propósito de travar o despovoamento nas zonas de fronteira continuou a ser uma preocupação dos monarcas, usando como solução a criação de coutos de homiziados. Estes só foram abolidos por D. Pedro II, tendo os seus privilégios cessado, definitivamente em $1790^{209}$.

Será durante o reinado de D. João III, a partir de 1527, que se iniciará o primeiro recenseamento da população do reino. Este registo foi feito na comarca de Trás-os-Montes em 1530. Nesta data, a vila de Outeiro conservava o seu castelo, onde apenas residia o alcaide, e contava com 62 moradores, totalizando 596 almas no conjunto dos seus termos. Curioso é verificar que as aldeias a sul de Outeiro - Carção, Santulhão e Argozelo eram as mais povoadas ${ }^{210}$. Deste registo ficamos a saber que mais de $10 \%$ da população total do concelho eram mulheres viúvas (65), 17 eram moças solteiras «que vyvem sobre sy» e 11 clérigos $^{211}$.

O último registo sobre a população do município de Outeiro é-nos dado nas Memórias Paroquiais de 1758, onde se diz que «tem noventa vizinhos e duzentas e setenta pessoas» ${ }^{212}$. Comparando com os números de 1527, parece que em pouco mais de dois séculos, o concelho perdeu 326 pessoas no total dos moradores dos termos.

\footnotetext{
207 Chancelarias Portuguesas: D. João I (1410-1418), 2006: vol. III, tomo 3, 139.

${ }^{208}$ Chancelarias Portuguesas: D. João I (1410-1418), 2006: vol. III, tomo 3, 139.

${ }^{209}$ MORENO, 1986b: 93-116. Ver também MORENO 1974: 13-63.

${ }^{210} \mathrm{O}$ concelho de Outeiro contava em $1530 \mathrm{com}$ as seguintes povoações e moradores: Outeiro - 62, Santulhão - 112, Carção - 76, Algoso - 84, Pinelo - 44, Vale de Pena - 10, Paradinha - 34, Quintanilha - 16, Veigas - 15, Milhão - 41, Rio Frio - 59 e Paço - 43. FREIRE, 1909: 265.

${ }^{211}$ FREIRE, 1909: 265.

212 CAPELA et al., 2007: 294-297.
} 


\subsubsection{A organização do território em torno do castelo}

A manutenção de uma fortaleza dependia não só do número de efetivos disponíveis que pudessem servir na vigilância e defesa da praça, como também dos impostos ou dos subsídios com que contava, dos recursos de abastecimento e das armas que poderiam armazenar. Todos estes aspetos determinavam o grau de efetividade do castelo na defesa e proteção das populações e, consequentemente, do reino ${ }^{213}$.

A planificação da manutenção e do abastecimento dos castelos levantava problemas de recursos, que o poder régio tentava resolver, aumentando ou diminuindo os privilégios e foros dos concelhos e garantindo que os seus termos e população fossem suficientes para dar resposta aos custos e esforços que uma fortaleza exigia.

No caso do castelo de Outeiro, foi ensaiado ao longo de algum tempo, a atribuição de um território com povoações e gente suficiente para garantir a gestão da fortaleza. Esta determinação territorial não foi consensual, pois o crescimento do município de Outeiro de Miranda implicava retirar proventos a Bragança e a Miranda do Douro. Estes protestos estão plasmados nos documentos, bem como a necessidade de manter o castelo de Outeiro operacional, pois era considerado peça essencial na defesa da região transmontana.

Depois de ter recebido foral em 1290, no qual não se estabelece os termos de «Outer de Muas», os moradores pedem ao monarca que os termos do concelho sejam alargados, para que pudessem fazer vila cercada. Numa carta datada de 28 de agosto de 1355, o vedor da comarca de "Aaquem dos Montes», João Aires, "vassalo d’el rei coregedor por el», determina que os habitantes deste município, não deveriam fazer cerca e não ver alargados os seus termos porque prejudicariam os concelhos de Bragança e Miranda, que tinham sido ouvidos previamente:

E eu veendo as dictas cartas e o que me pellas sobredictas erra pedido porque achei que se se [sic] cerca fezesse no dicto logo que seria per <juizo > aos concelhos da vila de Bragança e de Miranda mandei aos dictos moradores que citassem os dictos concelhos que per seus procuradores parecessem perante mim pera mostrar se aviiam algũas a enbargar a se nom fazer a dicta cerca em no dicto logo d'Outeiro e a thi nom darem termho das aldeas que aas dictas vilas pertencem ${ }^{214}$.

Sem recursos financeiros para construírem os muros e sem a autorização da Coroa, que se escusou a tomar parte na questão e patrocinar as obras, Outeiro terá ficado sem a sua cerca. Contudo, teria que ter recursos para sustentar a sua fortaleza que, como já vimos, surge referida na documentação a partir de 1361. As dificuldades

\footnotetext{
${ }^{213}$ QUINTANILLA RASO, 1987: 4-5.

${ }^{214}$ Trás-os-Montes Medieval e Moderno. Fontes Documentais. Séc. XIV, 2003: doc. 36.
} 
desta responsabilidade devem ter-se agravado durante os reinados de D. Pedro I e D. Fernando, porque em 1387, D. João I aumenta os rendimentos do castelo com as «rendas e djreitos das aldeas de pinjdello [sic] e d argusello e de santilham» ${ }^{215}$ (Mapa 2). Embora em 1395, o mesmo D. João I volte a retirar as rendas das aldeias de Pinelo, Argozelo e Santulhão ao castelo de Outeiro, em fevereiro de 1418, e porque «o nosso castello d outeiro de miranda he muy despouorado E esto por o dicto lugar teer muy pequeno termo e de muy poucas gentes $\mathrm{E}$ porque em os tempos das guerras nom he bem defensado per mjngoa de gentes que em elle nom há pera o auerem de defender e guardar» ${ }^{216}$, o monarca aumenta os termos deste concelho, incluindo novamente as aldeias de Pinelo, Argozelo e Santulhão, e acrescentando a aldeia de Carção, e Vale de Pena, dois lugares despovoados, e todas pertencentes ao termo de Miranda. Integra ainda a aldeia e lugar de Paradinha, Paçô, Rio Frio, Milhão e Quintanilha, esta última despovoada, e todos lugares que pertenciam ao termo de Bragança. Este acréscimo de terras, que o diploma diz ficarem próximas de Outeiro, totalizavam cerca de 100 homens.

Estabelecido um território suficientemente extenso com população mais numerosa, garantia-se que o castelo de Outeiro se mantivesse operacional defendendo uma extensa área que

de hũ cabo do termo ao outro, coatro legoas boas e ẽ largo hũa; e parte e confina com os concelhos seguintes: Parte e confina com a villa do Vymioso, que he de hũa villa á outra duas legoas. Parte e confina com a villa dAlgoso, que he de hũa villa á outra coatro legoas. Parte mais e confina com a cidade de Bragança, que he da dita vila á dita cidade três legoas. Parte e confina mais com a villa de Bemnavete, que he de hũa villa á outra catorze legoas, a saber: ao estremo, duas, e doze a Bemnavete; he senhor de Benavête o Conde de Benavẽte. Parte e confina mais com a villa dAlcaniças, que jaz nos ditos regnos de Castella e he de dom Francisco Amriqez, e he de hũa villa á outra coatro legoas, a saber: ao estremo, hũa; e do estremo Alcaniças, três, e quy se torna a juntar o termo desta villa com o do Vymioso ${ }^{217}$.

Este extenso território, com exceção de Vale da Pena, manteve-se até 1758, altura em que foram feitas as inquirições para as Memórias Paroquiais ${ }^{218}$. Contudo nesta data o castelo de Outeiro já se encontrava abandonado e em ruínas.

\footnotetext{
${ }^{215}$ Chancelarias Portuguesas: D. João I (1384-1388), 2005: vol. I, tomo 3, 143.

${ }^{216}$ Chancelarias Portuguesas: D. João I (1410-1425), 2006: vol. IV, tomo 1, 26-27.

${ }^{217}$ FREIRE, 1909: 265.

${ }^{218}$ CAPELA et al., 2007: 294-297.
} 


\subsubsection{A importância do castelo na defesa da fronteira e da região}

$\mathrm{O}$ estabelecimento da fronteira com a atual Espanha foi um processo gradual que se prolongou, grosso modo, até ao Tratado de Alcañices em 1297. Mesmo depois desta data, a partir da qual foram fixadas as linhas de separação entre os reinos de Portugal e de Castela, os problemas em algumas regiões, como na Beira Alta ou Alentejo, continuaram a alimentar desentendimentos entre as duas Coroas.

Na região Norte, a fronteira portuguesa parece ter-se fixado um pouco antes, ainda decorria o século XII. Nesta altura a linha de divisão entre os dois reinos desenhava-se

pelo curso do rio Minho, desde a foz até Melgaço, inclinando-se no sentido noroeste até ao Lindoso, numa linha coincidente com a actual fronteira. Dirigia-se depois para oriente, delimitando o território de Barroso e de Chaves e depois o de Bragança... A oriente de Bragança, estendiam-se as terras de Aliste, que Portugal apenas deve ter perdido no tratado de Alcañices ${ }^{219}$.

Com a definição definitiva da fronteira transmontana, havia que promover a sua defesa e povoamento. Esta política exigia que a Coroa desenvolvesse um conjunto de medidas administrativas, fiscais e militares que incentivassem a fixação da população de forma efetiva, garantindo a soberania das terras. Esta foi uma preocupação constante ao longo dos séculos, pois as zonas fronteiriças e de periferia eram evitadas pelas populações que receavam os ataques militares, as destruições, os saques, etc.

A responsabilidade pelo povoamento de Trás-os-Montes foi inicialmente «delegada» aos poderes senhoriais, ao clero e às ordens militares que, entretanto, estenderam os seus domínios a quase toda a região. A necessidade de cercear estes poderes particulares, como condição determinante para garantir a soberania do reino português, ganhou particular relevo a partir do reinado de D. Dinis que, como temos vindo a referir, tomou para a Coroa toda a zona fronteiriça de Bragança, criando uma série de concelhos rurais e determinando uma linha de estruturas militares que defendessem e protegessem as populações.

O castelo de Outeiro integra-se nesta primeira linha defensiva que se articulava com o castelo de Bragança, Vimioso e Miranda do Douro. Para além de ajudar na vigia da fronteira, nomeadamente as entradas pela zona de Quintanilha e Pinelo, controlava toda a zona de passagem pelo planalto português que se estendia entre Vimioso e Bragança, percurso muito usado nas deslocações de Bragança para sul, ou em sentido inverso, de Miranda para Bragança.

A par do seu papel de atalaia, o castelo de Outeiro também propiciava um local de refúgio para as populações da região, daí o interesse dos moradores em construí-

${ }^{219}$ SERRÃO, MARQUES, dir., 1996: 60-61. 
rem em 1355 uma cerca a par da fortaleza e aí erguerem as suas casas. Numa área tão extensa e com um vizinho tão poderoso, era natural que as populações não se sentissem seguras e temessem pelos seus bens e culturas, que dificilmente mantinham.

Mas houve também períodos de acalmia e de paz. Estes tempos favoreciam as trocas comerciais entre fronteiras, até porque o resto do reino ficava muito distante. Nestas alturas o castelo de Outeiro não era apenas uma sentinela, mas erguia-se também como um marco que recordava a separação de um território, a sua autonomia e autoridade.

É com este papel de marco e de referência que nos surge em 1450 numa inquirição feita em Bragança para se confirmarem os termos desta vila com Castela ${ }^{220}$. Esta averiguação surge um ano após aquele território transmontano ter sido entregue ao duque D. Afonso, e de se terem levantado dúvidas sobre o pagamento de determinados foros que alguns castelhanos deveriam pagar em Portugal, pois alegava-se que as terras que exploravam ficavam dentro dos termos da Coroa portuguesa. A questão levantou-se porque «de pouco tempo aca Diego d'Allmança se metia per o dicto termo de Bragança acerca de mea legoa aquém do dicto rio fazendo tirar os marcos e poendo os aquém onde lhe aprouvera em prejuízo do dicto termo de (1 v.) Bragança em o qual termo de Bragança hordenara hũua ferraria de que tiravam ferro» ${ }^{221}$.

Reunidas «allgũuas testemunhas antigaas de que ouvessem emformaçom que dello soubessem a verdade», os juízes interrogaram-nas, ficando-se a saber, pela boca de Afonso de Caravela, morador na aldeia de Caravela, que:

acordava bem cinquoeenta anos e que sempre em este tempo sabia partir o dicto termo pella veea da augua do rio Maçãas dello castello de Mall Vizim que he em direito dos castello d'Outeiro de Miranda pella augua arriba de Maçaas ataa Gavançall que he ao direito de Pena de Miro e da auga pera aca de Portugall e da augua pera allem era de Castella e do Gavançall se hiia a Prado de Rex que parte com Seabra e daly a rio d'Onor e ende a Canpiça e emde a Penellas Mallas.

A mesma testemunha acrescenta que se recorda que há cerca de 50 anos, se haviam reunido, na aldeia de Maçãs o bispo de Zamora, o arcebispo de Braga, D. Martinho, um Gomes Martins, um cavaleiro a quem chamavam Gomes Fernandes e muitos outros, para «demarcarem os dictos termos e fizeram perante sy viir muytas testemunhas antigaas per que fora tirada há enquiriçom». Para este processo de demarcação da fronteira foi construída uma casa «na metade do rio de Maçaas ao porto da Caalhelha onde hiiam certos dias da somana pera determinarem os dictos

\footnotetext{
${ }^{220}$ As Gavetas da Torre do Tombo, 1975: XI, 51-66.

${ }^{221}$ As Gavetas da Torre do Tombo, 1975: XI, 51-66.
} 
termos com as dictas testemunhas e que as testemunhas mais antigaas», entre as quais se encontravam moradores de Castela e de Portugal. Os limites foram marcados «per a veea da augua como dicto he e que outros marcos nom foram postos sallvo o dicto rio» ${ }^{222}$.

As testemunhas confirmaram ainda que os moradores da aldeia de Maçãs, que ficava do lado de Castela, pagavam as sacadas dos terrenos cultivados do lado de cá do rio, ao erário de Portugal. Acrescentaram ainda que cerca de 14 ou 15 anos antes, «Luis d'Allmança», senhor castelhano, «se metera em posse do rio pera aca a cerca de mea legoa e que nom ouvera quem lho contradizer porque aquelle tempo era aqui allcayde João Gomez e que avia merces e bemfazer do dicto Luis d'Allmança e portanto lho nom contradezia o dicto Joham Gomez e que dello all nom sabiia» ${ }^{223}$.

Perante o que ficou apurado, e verificando-se que houve abusos e tomada indevida de terras no território português, os desembargadores pedem ao rei que escreva ao duque de Bragança para que este faça repor a antiga fronteira naquela zona de Bragança, obrigando a que os marcos sejam repostos nos seus lugares de origem. Curioso será reparar que nesta zona de fronteira, e na atualidade, a marcação não segue o rio Maçãs, mas entra, sensivelmente em frente à aldeia espanhola de Riomanzanas, cerca de $3 \mathrm{~km}$ no território português, o que corresponderá à meia légua referida no documento de 1450. Deduz-se que a disputa pelos terrenos da margem direita do rio Maçãs não foi ganha pelo duque de Bragança, ficando na posse de Castela até hoje (Mapa 4).

Ainda não tinha passado um século da anterior inquirição sobre a fronteira bragançana, e já se procedia, em 1538, a uma nova averiguação da fronteira do reino. $\mathrm{Na}$ zona de Outeiro, reuniram-se os inquiridores na casa da câmara, e foram interrogados os oficiais do concelho e algumas testemunhas, moradoras nas aldeias dos termos. Todos confirmaram que

o termo desta villa partyndo com Castella pello lombo da dicta sera de Rompe Barcas per o memo do cume da dicta sera agoas vertentes a mao direita pera Vilarynho que hora he termo d'Allcaniças e maom esquerda agoas vertentes pera Portugall e core a demarcação per toda a sera ao dyante de Rompe Barquas ate que a dicta sera do cume e meo della dece pera baixo... ate passar per o meio de hum arryffe de pedra que atravesa a dicta sera [...] e entaom torna a demarcação desta villa hyr ao dyreyto per outro lombo que vay sobymdo per o meio do dyto lombo e cume da dicta sobyda ate cabeço allto que tem em cyma hua penidya aguda que se chama o Castello de Mallvizinho e vay a demarcaçao ter ao meio

222 As Gavetas da Torre do Tombo, 1975: XI, 51-66.

${ }^{223}$ As Gavetas da Torre do Tombo, 1975: XI, 51-66. 
do dyto outeiro e pinidya e no mais allto por hy vay a demarcação ate o cume mais allto do dicto outeiro agoas vertentes a mao direita pera Castella e a maom esquerda pera Portugall e do dicto picoto [...] torna logo a demarcação desta villa a partyr com Castella per o meio de hum lombo que dece delle pera hy abaixo ao direito [...] a hum valle e rybeiro que core em baixo que se chama o Ervedall e per hua banda do dicto rybeiro vaom ter direito a hua rybeira que vem de cyma de Castella que se chama Ryo de Maçaas e chega o valle e dece marcação a dicta rybeira ahonde se chama hy a Boqua do Ervedall e ate aquy sempre per esta seras e cumes per o meio della [...] parte o seu termo com Castella sem nunca ate ora terem com Castella nhuua duvida [...] e que ahy onde chega o termo per terá a dicta rybeira das Maças onde se chama a Boca do Ervedall dahy pera (fl. 46 ${ }^{a}$ ) cyma vam o termo desta villaa partyndo mais seu termo per a dyta rybeira das Maças acyma... ate em direito d'alldea de Quyntanilha o termo desta villa ahy se acaba de partyr com o termo d'Allcaniças [...] e sempre vay o termo partindo com Castella per ofyo e meo da agoa da dicta rybeira a metade della he termo desta villa e a outra termo de Castella sem nunca sobre o partyr dos termos per o dyto rio esta villa ter nhuua referta contenda debate com Castella senam cada concelho e lugar posue a metade da dicta rybeira e sempre estyveram em pose pacyfyca [...] nessa pose estaom de cento dozentos anos a esta parte te o dia d'oje 224 . (Mapa 5)

Mais uma vez podemos observar que a fronteira entre os termos de Outeiro, em 1538, e a demarcação atual coincidem no essencial.

Se no século XVI não se mencionam marcos que delimitassem a fronteira, aproveitando-se os acidentes naturais como referências, três séculos mais tarde, em 1886, seria feita uma demarcação da fronteira entre Portugal e Espanha, com marcos numerados que assinalavam a separação entre os dois países, desde o rio Minho até ao Guadiana.

Na zona de Outeiro os limites são os mesmos do século XVI, sendo assinalados com os marcos n. 444 na serra de Rompe Barcas, seguindo para norte, até ao castelo do Mau Vizinho que tem o marco n. ${ }^{\circ}$ 439. Daqui segue até perto da foz da ribeira do Ervedal, que desce de Espanha até ao rio Maçãs. Aí foi colocado o marco «N. 438 Sobre uma rocha mui dura que está na margem esquerda do rio Maçans no sitio chamado o Poço da Ola no termo da villa do Outeiro povoação portugueza e logar de Latedo de Hespanha» ${ }^{225}$. Para norte a fronteira segue o curso do rio Maçãs, até junto da aldeia da Petisqueira, onde deixa o curso de água e inflete para oeste.

224 Demarcações de Fronteira: lugares de Trás-os-Montes e Entre-Douro-e-Minho, 2003: 59-63.

${ }^{225}$ As Gavetas da Torre do Tombo, 1977: XII, 246-290. 
Aqui foi colocado o marco «N. $437 \mathrm{Na}$ falda do monte no sitio chamado a Apertadura ou da Pedra Furada. Está a uns 60 metros do rio Maçans. Aqui há um marco pequeno muito tosco» ${ }^{226}$.

Será esta fronteira que parece ter-se fixado em 1450, que perdurou até aos nossos dias. Na carta militar ainda vemos os marcos com a numeração de 1886, marcando os limites entre os dois reinos rivais. O castelo de Outeiro manteve-se durante todos estes séculos como sentinela, garantindo que estas terras tinham senhor e que eram habitadas por «gentes portuguesas». Os políticos aboliram as portagens, mas os marcos continuam a dividir a terra e o castelo de Outeiro, mesmo em ruína, continua a vigiar a fronteira que tanto custou a manter.

\subsubsection{Os alcaides-mores do castelo de Outeiro}

$\mathrm{O}$ aparecimento do cargo militar de alcaide-mor surge como consequência das políticas centralizadoras da Coroa portuguesa que, paulatinamente foi controlando os poderes da nobreza. As terras, dominadas por tenentes, foram reformadas e deram lugar aos julgados, onde se acentuou a dimensão civil e judicial em detrimento da função militar. Durante o reinado de D. Dinis o cargo de tenente é abolido, em 1287, sucedendo-lhes os alcaides de nomeação régia ${ }^{227}$.

Os alcaides deveriam ser escolhidos entre a nobreza de forma a assegurarem determinadas qualidades morais e militares. Estavam obrigados a um juramento de fidelidade, ato inerente a alguém com estatuto nobiliárquico. $\mathrm{O}$ cargo exigia do seu detentor a capacidade em manter a honra e o zelo no cumprimento das suas tarefas, qualidades que engrandeceriam a sua família e linhagem ${ }^{228}$.

Segundo as Ordenações Afonsinas os alcaides-mores eram os responsáveis pelos castelos e tinham como tarefas defender a fortaleza, assegurar a presença de efetivos na guarnição militar, bem como, garantir mantimentos e armas para a defesa da praça. Para cumprir estas obrigações recebiam uma tença e os direitos procedentes de penas e coimas aplicadas pela Justiça ${ }^{229}$.

Quando se tratava da nomeação de um alcaide para uma fortificação de fronteira, o cuidado era redobrado, pois exigia-se do escolhido não só destreza militar, mas também tato político, pois, não raras vezes, o alcaide era chamado a intervir e gerir problemas fronteiriços, questões relacionadas com trocas comerciais, cumprimento de tratados, vigilância da fronteira e custódia e entrega de prisioneiros ${ }^{230}$.

\footnotetext{
${ }^{226}$ As Gavetas da Torre do Tombo, 1977: XII, 246-290.

227 BARROCA, 1998: 805.

${ }^{228}$ QUINTANILLA RASO, 1987: 13-14.

${ }^{229}$ BARROCA, 2003a: 94.

${ }^{230}$ QUINTANILLA RASO, 1987: 13-14.
} 
Mas, apesar dos requisitos exigidos, eram frequentes as queixas que acusavam os alcaides de darem cobertura e guarida a mercenários e malfeitores e de que os encarcerados tinham más condições e sofriam maus tratos. Muitas vezes o alcaide acabava por libertar os presos para não serem sustentados ${ }^{231}$.

Em situação de conflito, nomeadamente de cerco ao castelo, e quando as forças sitiadas sabiam que não tinham recursos para resistir, o alcaide tentava um compromisso com as forças inimigas, comprometendo-se a entregar a praça, logo que tivesse autorização do seu senhor. Em troca abandonaria o castelo em segurança com os seus homens ${ }^{232}$. Estas rendições nem sempre foram simples e consensuais, como nos mostram os casos ocorridos nas guerras durante o reinado de D. Fernando, em 1369, em que o monarca castigou os «traidores» que não souberam guardar as cidades de Braga, Vinhais e Bragança, permitindo que o rei castelhano as tomasse ${ }^{233}$.

Atentemos agora mais pormenorizadamente nos alcaides do castelo de Outeiro.

Com base nos documentos por nós consultados, a primeira referência a um alcaide responsável pelo castelo de Outeiro, data de 1361. Neste diploma, D. Pedro I entrega a fortaleza a João Rodrigues de Basto para ele lhe fazer menagem ${ }^{234}$. Um ano mais tarde, em dezembro de 1362, o mesmo monarca entregará o mesmo castelo a Rodrigo Alvares de Bornes, um seu vassalo ${ }^{235}$.

Durante o reinado de D. João I e logo em 1385, a aldeia de Outeiro de Miranda é doada a Martim Gonçalves de Macedo, escudeiro do rei ${ }^{236}$. No documento é apenas referida a aldeia, não se especificando se o escudeiro assumiu a alcaidaria da fortaleza. No entanto, o Abade de Baçal refere na sua obra que este escudeiro foi alcaide do castelo de Outeiro logo após a Batalha de Aljubarrota: «Martim Gonçalves de Macedo, atrás citado, socorreu El-Rei D. João I na batalha de Aljubarrota, matando Álvaro Gonçalves de Sandoval, cavaleiro castelhano, que lhe tomara a massa. Por recompensa fez-lhe El-Rei mercê da alcaidaria do castelo de Outeiro, dos direitos reais de Bragança e de muitos outros.» ${ }^{237}$

Entretanto, e talvez fruto da conjuntura conturbada que caracterizou o início do reinado do Mestre de Avis ${ }^{238}$, os direitos do lugar de Outeiro serão entregues em

\footnotetext{
231 COELHO, 1989-1990: 261.

${ }^{232}$ MONTEIRO, 2003: 231-232.

${ }^{233}$ GOMES, 2009: 94.

${ }^{234}$ Chancelarias Portuguesas: D. Pedro I (1357-1367), 1984: 268.

${ }^{235}$ Chancelarias Portuguesas: D. Pedro I (1357-1367), 1984: 348.

${ }^{236}$ Chancelarias Portuguesas: D. João I (1384-1388), 2005: vol. I, tomo 3, 115.

${ }^{237}$ ALVES, 2000: VI, 250.

${ }^{238} \mathrm{O}$ reinado de D. João I iniciou não só em contexto de guerras, mas com algumas dificuldades administrativas, pois segundo Maria Helena da Cruz Coelho «sendo o Mestre e jovem monarca um governante sem experiência anterior, rodeado essencialmente por um grupo de novos oficiais, o desembargo régio nestes anos iniciais caracterizou-se por uma certa desorganização, que levou até, não poucas vezes, a dar o mesmo a muitos [...]. Detectou-se um apagamento dos grandes cargos tradicionais por ausência dos seus titulares e tendeu-se à pessoalização do despacho. Assim, as cartas
} 
1387 a Fernando Afonso, mencionado na carta como alcaide do castelo de Outeiro de Miranda. O monarca afirma no documento, que o alcaide deverá dispor das rendas e foros da aldeia, independentemente de estes terem sido doados a Gonçalves de Macedo ou a qualquer outro ${ }^{239}$.

Fernando Afonso terá ficado à frente da alcaidaria de Outeiro cerca de 5 anos, pois em 1392, D. João I volta a entregar a Martim Gonçalves de Macedo, seu escudeiro, os direitos sobre as dízimas e portagens de Bragança e de Outeiro de Miranda ${ }^{240}$. E se anteriormente tínhamos dúvidas se o escudeiro do rei tinha realmente assumido a alcaidaria da fortaleza raiana, essas dúvidas dissipam-se, pois, numa carta, com data de dezembro de 1400, o monarca refere claramente Martim Gonçalves de Macedo como seu vassalo e alcaide do seu castelo de Outeiro de Miranda, doando-lhe todas as dízimas dos panos que vêm de Castela para a vila ${ }^{241}$.

Se até à data a alcaidaria de Outeiro havia sido entregue a vassalos do rei, em 1414, numa carta em que D. João I manda fazer uma cerca a par da fortaleza, para que os habitantes da região possam lá construir casas, é referido o abade do mosteiro de Castro de Avelãs como alcaide do castelo: «Porem fiando nos do dom abade de crasto d auellaãs alcaide do dicto castello» ${ }^{242}$.

A escolha de um clérigo para alcaide de um castelo não parece muito comum, contudo não é inédita. No século X, D. Mumadona mandou construir o castelo de $\mathrm{S}$. Mamede para defender o seu mosteiro. Segundo a condessa a chefia da fortaleza deveria ser entregue a alguém da sua descendência, mas depois da morte dos seus filhos, seria a comunidade monástica a eleger o tenente de entre os seus netos ${ }^{243}$. Neste caso o tenente do castelo de Guimarães não teria que ser clérigo, cabendo a estes apenas a sua escolha. Contudo, no caso do castelo de Alcobaça, construído em 1178 , também para a defesa do mosteiro cisterciense, o seu tenente seria o abade do mosteiro ${ }^{244}$.

Apesar dos exemplos apresentados serem de épocas muito recuadas e referentes a conjunturas políticas muito específicas, poderá pôr-se a hipótese de, em situações excecionais, os monarcas terem que recorrer às casas monásticas para recrutarem os seus vassalos. Lembramos que em 1414, Portugal estava em paz com Castela e preparava-se para a expedição a Ceuta ${ }^{245}$. Para esta grandiosa empresa, D. João I terá

\footnotetext{
que o monarca não subscreveu pessoalmente [...] foram redigidas por "simples" desembargadores, não detentores dos principais cargos, que, portanto, se vinculavam ao soberano sobremaneira por ligações individuais de confiança pessoal e política». COELHO, 2008: 207.

${ }^{239}$ Chancelarias Portuguesas: D. João I (1384-1388), 2005: vol. I, tomo 3, 241.

${ }^{240}$ Chancelarias Portuguesas: D. João I (1385-1392), 2005: vol. II, tomo 1, 303.

${ }^{241}$ Chancelarias Portuguesas: D. João I (1391-1407), 2005: vol. II, tomo 3, 170.

${ }^{242}$ Chancelarias Portuguesas: D. João I (1410-1418), 2006: vol. III, tomo 3, 173.

${ }^{243}$ MOREIRA, dir., 1989: 46.

${ }^{244}$ MOREIRA, dir., 1989: 53.

${ }^{245}$ COELHO, 2008: 245-251, 409.
} 
recrutado grande parte da nobreza com experiência militar, não sendo de estranhar que, entre estes, se contassem alguns alcaides de castelos, sobretudo os de praças mais pequenas. Por essa razão, havia que designar alguém da confiança do monarca, e no caso de Outeiro, alguém do âmbito eclesiástico.

A última notícia de um alcaide-mor no castelo de Outeiro, durante o reinado do Mestre de Avis, surge numa carta datada de 1421 onde D. João I dá autorização à criação de um couto de homiziados em Outeiro de Miranda. Neste diploma é referido Diego Gonçalves o Rombo como alcaide do castelo ${ }^{246}$.

Já depois do castelo de Outeiro ter sido entregue ao duque de Bragança, em 1449, teremos novamente notícias de um alcaide nesta fortaleza, de seu nome João de Macedo, que é referido numa carta com data de $1483^{247}$. Segundo o Abade de Baçal, este João de Macedo ainda era alcaide-mor de Outeiro em $1497^{248}$, e terá sido capitão general nas guerras entre D. Afonso V de Portugal e D. Fernando de Castela, no ano de $1476^{249}$.

Em 1503, num contrato de venda em que o duque de Bragança compra

ao senhor Lopo de Sousa do conselho d'El Rey nosso senhor e ayo do senhor duque, governador de suas terras e alcaide moor e capitam da dita cidade e da villa d'Outeiro e fronteiro na comarca de Tralos Montes pello dito senhor duque as casas que foy 'snoga dos judeus e judias com seu curral segundo mays largamente se ber podera pella carta que das ditas casas tinha as quaes casas asy comprarom para a dita cidade para casa de cadea ${ }^{250}$.

é o próprio duque, D. Jaime (1479-1532), que é referido como alcaide-mor e capitão da vila de Outeiro. Contudo, no Livro das Fortalezas de Duarte de Armas, refere-se Lopo de Sousa como alcaide-mor do castelo de Outeiro entre 1479 e $1522^{251}$.

Mais uma vez Abade de Baçal escreve que durante a jurisdição do duque D. Jaime, terá sido alcaide-mor de Bragança e de Outeiro Francisco da Costa ou Francisco da Costa Homem ${ }^{252}$. Talvez tenha ocupado o cargo depois de 1522, substituindo Lopo de Sousa.

No recenseamento feito em Trás-os-Montes em 1530, diz-se que o castelo de Outeiro é do duque de Bragança e que nele apenas vive o alcaide, contudo não se refere o seu nome $e^{253}$.

\footnotetext{
${ }^{246}$ Chancelarias Portuguesas: D. João I (1410-1418), 2006: vol. III, tomo 3, 173.

${ }^{247}$ ANTT. Chancelaria de D. João II, liv. 26, fol. 106.

${ }^{248}$ ALVES, 2000: I, 321-322.

249 ALVES, 2000: VI, 13.

${ }^{250}$ ALVES, 2000: III, 198-200.

${ }^{251}$ ARMAS, 2006: 16.

${ }^{252}$ ALVES, 2000: III, 324.

${ }^{253}$ FREIRE, 1909: 265.
} 
Para além das fontes documentais por nós compulsadas, a bibliografia, sobretudo o Abade de Baçal, referem ainda outros nomes como alcaides e capitães do castelo de Outeiro, sobretudo para a época contemporânea, nomeadamente entre os séculos XVII e XVIII ${ }^{254}$.

Tabela 3. Cronologia dos alcaides-mores do castelo de Outeiro referidos na documentação

\begin{tabular}{|c|c|c|}
\hline 1361 & João Rodrigues de Basto & Chancelarias Portuguesas:D. Pedro I (1357-1367), 1984: 268. \\
\hline 1362 & Rodrigo Alvares de Bornes & Chancelarias Portuguesas:D. Pedro I (1357-1367), 1984: 348. \\
\hline 1385 & Martim Gonçalves de Macedo & $\begin{array}{l}\text { Chancelarias Portuguesas: D. João I (1384-1388), 2005: vol. } \\
\text { I, tomo 3, } 115 .\end{array}$ \\
\hline 1387 & Fernando Afonso & $\begin{array}{l}\text { Chancelarias Portuguesas: D. João I (1384-1388), 2005: vol. } \\
\text { I, tomo 3, } 241 .\end{array}$ \\
\hline 1392 & Martim Gonçalves de Macedo & $\begin{array}{l}\text { Chancelarias Portuguesas: D. João I (1385-1392), 2005: vol. } \\
\text { II, tomo 1, } 303 .\end{array}$ \\
\hline 1400 & Martim Gonçalves de Macedo & $\begin{array}{l}\text { Chancelarias Portuguesas: D. João I (1387-1402), 2005: vol. } \\
\text { II, tomo 3, } 170 .\end{array}$ \\
\hline 1414 & Abade do mosteiro de Castro de Avelãs & $\begin{array}{l}\text { Chancelarias Portuguesas: D. João I (1410-1418), 2006: vol. } \\
\text { III, tomo 3, } 173 .\end{array}$ \\
\hline 1421 & Diego Gonçalves o Rombo & $\begin{array}{l}\text { Chancelarias Portuguesas: D. João I (1410-1418), 2006: vol. } \\
\text { III, tomo 3, } 139 .\end{array}$ \\
\hline 1483 & João de Macedo & ANTT. Chancelaria de D. João II, liv. 26, fol. 106. \\
\hline 1503 & Duque de Bragança, D. Jaime & ALVES, 2000: III, 198-200. \\
\hline 1497-1522 & Lopo de Sousa & ARMAS, 2006: 16. \\
\hline$?^{255}$ & Francisco da Costa ou Francisco da Costa Homem & ALVES, 2000: III, 324. \\
\hline 1530 & $?$ & FREIRE, 1909: 265. \\
\hline
\end{tabular}

Fonte: Elaboração própria

\subsection{NOTÍCIAS SOBRE AS OBRAS NO CASTELO DE OUTEIRO}

Com o fim da Reconquista no território português e após a assinatura do Tratado de Alcañices em 1297, as atenções dos monarcas vão-se voltar para a defesa da linha de fronteira com Castela. Nesta altura, e já durante o reinado de D. Dinis, o controlo exclusivo da construção de fortificações passa a ser somente da Coroa. Para Trás-os-Montes, há notícias de que o monarca promoveu reformas em seis castelos, mas entre eles não se conta o de Outeiro ${ }^{256}$.

Como já referimos várias vezes neste trabalho, a primeira notícia de construções em Outeiro, surge em 1355, num pedido dos moradores para fazerem vila cercada no lugar de Outeiro ${ }^{257}$. Não podemos confirmar a existência de um castelo nesta

\footnotetext{
${ }^{254}$ Para consulta destes alcaides e governadores ver ALVES, 2000: VI.

255 Terá sido alcaide-mor de Outeiro durante o ducado de D. Jaime, não especificando, o autor, a data concreta. ALVES, 2000: III, 324.

256 BARROCA, 1998: 807.

${ }^{257}$ Trás-os-Montes Medieval e Moderno. Fontes Documentais. Séc. XIV, 2003: doc. 36.
} 
data, contudo há uma forte probabilidade da sua existência. O diploma dá conta da recusa, por parte do corregedor e vedor de Trás-os-Montes, em aceder ao pedido da povoação, alegando prejuízos para os concelhos de Bragança e Miranda.

Apesar da responsabilidade da construção e reparação das fortalezas ser da Coroa, cabia a estes delegados régios, os vedores, a averiguação do estado das fortificações e o posterior relato ao monarca da situação e das possibilidades para a resolução dos problemas $^{258}$. Na carta de 1355, onde o vedor resume todo o processo do pedido, ficamos a saber que é o próprio monarca a incumbir o funcionário régio de averiguar o pedido dos moradores de Outeiro e decidir sobre a sua conclusão.

Durante o reinado de D. Fernando não há notícias de reformas do castelo de Outeiro, contudo sabemos que esteve envolvido nas campanhas contra Castela em 1369, podendo daí ter resultado algum dano na fortaleza.

Em 1414, D. João I manda «fazer huũ cerco de villa a par do nosso castello d outeyro de mjranda a qual cerca he Ja fecta boa parte» ${ }^{259}$. Para além da conclusão da cerca o monarca dá autorização para que os moradores construam casas dentro da dita cerca, incumbindo o abade de Castro de Avelãs de passar alvarás e proceder à divisão do terreno, conforme cada um mereça. No mesmo documento, diz-se ainda «que as casas seiam fectas em boa hordenanças pera as Ruas vijrem bem fectas», mostrando preocupação com o ordenamento da vila.

Cerca de 4 anos depois de D. João I ter mandado concluir a cerca de Outeiro, portanto, em 1418, o monarca volta a dirigir a sua atenção para o castelo da vila pois insiste que

o nosso castello d outeiro de miranda he muy despouorado E esto por o dicto lugar teer muy pequeno termo e de muy poucas gentes E porque em os tempos das guerras nom he bem defensado per mjngoa de gentes que em elle nom há pera o auerem de defender e guardar E a nos conuem de olharmos por elle e o proueermos de moor termo e mais gentes pera nosso serujço e guarda do dicto lugar E mandamos em elle ora fazer obras e cousas que comprem ao dicto castello de sse em elle fazer por bem da terra ${ }^{260}$.

Para além de despovoado, o castelo precisava de obras, vendo-se o monarca obrigado a alargar os termos do concelho de Outeiro de Miranda, dotando-o de mais gente e foros, que financiassem as reparações necessárias. Infelizmente não se especifica o estado do castelo nem as obras que eram necessárias fazer.

\footnotetext{
${ }^{258}$ QUINTANILLA RASO, 1987: 6-7.

${ }^{259}$ Chancelarias Portuguesas: D. João I (1410-1418), 2006: vol. III, tomo 3, 173.

${ }^{260}$ Chancelarias Portuguesas: D. João I (1410-1425), 2006: vol. IV, tomo 1, 26-27.
} 
Contudo, e segundo Francisco Felgueiras, o castelo de Outeiro manteve-se deteriorado durante todo o reinado de D. João I, tendo sido apenas reparado por D. Afonso $\mathrm{V}^{261}$.

A necessidade de manter os castelos operacionais era uma preocupação consciente e discutida entre a monarquia. Numa carta, datada de 1426, enviada de Bruges por D. Pedro ao seu irmão D. Duarte, o infante defende que o governo do reino deve assentar em quatro pilares fundamentais: Fortaleza, Justiça, Temperança e Prudência. Quando esclarece os propósitos da Fortaleza, D. Pedro observa que esta assenta num reino preparado e bem defendido e, que, para isso, deveriam haver vassalos em número suficiente, preparados e convenientemente recompensados. Também se deveriam fazer obras nos castelos, mantê-los bem conservados e com os armazéns bem abastecidos ${ }^{262}$.

Mas o facto é que, depois do plano de reformas militares executado durante o reinado de D. Dinis, o sistema defensivo português só conhecerá uma nova renovação durante os reinados de D. João II e D. Manuel I, que adaptaram as velhas fortificações às inovações da pirobalística ${ }^{263}$. Será mesmo durante o reinado de D. Manuel I que Duarte de Armas, escudeiro do monarca, executará, a partir de 1509, um levantamento das fortalezas fronteiriças do reino, para que a Coroa pudesse avaliar o seu sistema de defesa.

Num documento datado de 1508, percebemos que na região de Trás-os-Montes este fluxo renovador já estava em marcha, pois faz-se referência a obras nos castelos de Chaves, Mós (Torre de Moncorvo), Outeiro, Vinhais e Bragança. As cartas trocadas entre os funcionários da comarca tratam de questões de pagamento de materiais e mão de obra, havendo divergências entre as diferentes dignidades. Em resposta às queixas dos moradores, que diziam ser obrigados a pagar a mão de obra dos mestres, sendo costume este encargo ficar por conta do erário régio, Lopo de Sousa, alcaide-mor da cidade de Bragança e vedor das obras da comarca de Trás-os-Montes, responde «que em outeiro camdo cayo [o mu] ro da billa que o corregeo a terra e que pouco tempo ha [...] que um pedaço delle e o corregerom ${ }^{264}$, justificando o mesmo procedimento nas restantes vilas.

Entre 1508 e 1530 não temos notícias de obras no castelo de Outeiro, referindo-se apenas no recenseamento das povoações de Trás-os-Montes de 1530, que a vila tinha um bom castelo e nele vivia apenas o alcaide ${ }^{265}$. Presumimos que nesta data a fortaleza estaria operacional e em bom estado.

\footnotetext{
${ }^{261}$ FELGUEIRAS, 1968: 9.

262 COELHO, 1989-1990: 236-237.

${ }^{263}$ BARROCA, 1998: 802.

${ }^{264}$ ALVES, 2000: VIII, 148-156.

${ }^{265}$ FREIRE, 1909: 265.
} 
A última notícia documental sobre o estado do castelo de Outeiro é-nos dada nas Memórias Paroquiais de 1758, onde se escreve:

Há nesta villa hua fortaleza [sic, por fortaleza] de hum castelo, inconquistavel em razam do sitio em que se acha, o qual está formado na eminencia de hum outeiro, distante da villa três tiros de bala, tem duas torres, cazas para morarem os governadores e soldados, tinha sua cappella de Santa Luzia, porém esta e as cazas se acham quasi demolidas e damnificadas as muralhas por razam de nam habitarem há anos os governadores na ditta fortaleza, e juntamente incalamidades dos tempos... No Terramoto de mil settecentos e sincoenta e sinco cahiu hua amea, nam se tem reparado. A ditta praça me consta hoje nam tem peça algua, nem moniçons; cada dois mezes vem hua escoadra de infantes da Praça de Bragança com seo sargento e alferes ${ }^{266}$.

No segundo quartel do século XVIII o castelo de Outeiro já tinha iniciado o seu processo de abandono. Em 1762, depois de um ataque de tropas espanholas, o castelo ficou muito destruído iniciando o seu processo de degradação. De então para cá ficaram a sobrar apenas alguns troços de muralha em ruínas.

Apesar do "profundo respeito e grande orgulho» que a gente de Outeiro sentia pelo seu castelo, ao ponto de lhe dedicar uma quadra: «Castilo de Otero, / orejas de liebre; / Portugal te mira, / España te teme.» ${ }^{267}$, a fortaleza não foi contemplada pelas «reformas» do Estado Novo. Devido ao seu estado de ruína, foram feitas algumas consolidações, em 1993, nos muros que ainda se encontravam erguidos ${ }^{268}$. De então para cá o castelo tem estado silencioso e esquecido, contudo presente, marcando a paisagem.

\subsection{DE UM CASTELO RÉGIO A UM CASTELO SENHORIAL}

Como já muitas vezes foi referido, a aldeia de Outeiro entrou na posse da Coroa em 1290, altura em que recebeu foral de D. Dinis. Nesta altura não é certo que existisse alguma estrutura militar em Outeiro e que ela estivesse, ou passasse a estar, sob o controlo da Coroa.

Passados 23 anos sobre o foral de Outeiro, D. Dinis doa ao seu filho D. João Afonso, algumas aldeias em Trás-os-Montes, encontrando-se, entre elas Outeiro de Miranda $^{269}$. Mais uma vez, não se faz referência a nenhuma estrutura militar.

\footnotetext{
266 CAPELA et al., 2007: 294-297.

${ }^{267}$ FELGUEIRAS, 1968: 9.

${ }^{268}$ Informação retirada da Direção-Geral do Património Cultural: http://www.patrimoniocultural.pt.

${ }^{269}$ As Gavetas da Torre do Tombo, 1962: II, 31.
} 
Como consequência dos conflitos entre D. Dinis e o seu herdeiro D. Afonso IV, e após a subida deste ao trono, O Bravo mandará executar, em 1326, o seu irmão D. João Afonso acusando-o de traição e confiscando-lhe todos os bens ${ }^{270}$. Mais uma vez, Outeiro de Miranda ficará diretamente sob a alçada da Coroa até ao reinado de D. Fernando, período em que a documentação já refere o castelo.

Segundo Manuela Mendonça, D. Fernando doará a cidade de Bragança a D. João Afonso Pimentel em dote de casamento da sua cunhada, D. Joana Teles, com este nobre ${ }^{271}$. Embora esta autora não faça referência a Outeiro, a vila fazia parte da doação ${ }^{272}$.

Após a morte de D. Fernando, grande parte das praças transmontanas tomaram voz por D. Beatriz, rainha de Castela, tendo sido tomadas por D. João I e pelo seu Condestável em $1386^{273}$. Os castelos de Bragança e de Outeiro são então retirados a D. João Afonso Pimentel e entregues a D. Fernando, sobrinho do rei e filho de D. João, meio-irmão do Mestre de Avis. Quando D. Fernando morreu, as vilas passaram para o seu filho D. Duarte, ficando em sua posse até 1442, altura em que morre sem descendência ${ }^{274}$.

Neste ano, 1442, e durante a regência de D. Pedro, é criado o ducado de Bragança e entregue a D. Afonso, filho bastardo de D. João I. D. Afonso era conde de Barcelos e passa a ser o primeiro duque de Bragança. Da doação faziam parte a vila e o castelo de Outeiro ${ }^{275}$.

Com data de 1449, e já depois de D. Pedro se ter afastado da regência do reino, o Abade de Baçal dá conta de uma carta de D. Afonso IV em que o monarca doa a

Villa de Bragança com seu Castello, e o Castello douteiro de Miranda, e Nozellos com todos os seus termos, e rendas, e padroados, e direitos novos, e antigos que a nos, e aos Reys dante nos pertencem, e de direito pertencer podem, nos ditos lugares, com toda sua jurisdição civel, e crime mero, e mixto imperio, reservando pera nos as alçadas, e que elle possa poer, e fazer Juizes, Alcaides, e Meirinhos, Escrivaẽs, e todolos officios que aos ditos lugares, e termos pertencerem, e falecendo algum de seus descendentes sem filho, que venha a filha, e naõ havendo hi filho, ou filha, que o haja o descendente que hi ouver do dito Duque mais chegado ${ }^{276}$.

\footnotetext{
${ }^{270}$ SOUSA, 2009: 84-86.

${ }^{271}$ MENDONÇA, 1995: 241-242.

${ }^{272}$ FREITAS, 2009: 129.

${ }^{273}$ COELHO, 2008: 122-123.

${ }^{274}$ FREITAS, 2009: 130.

${ }^{275}$ COSTA, 1868: 495-497; MENDONÇA, 1995: 242-243; FREITAS, 2009: 130.

${ }^{276}$ SOUSA, 1949: 69-70.
} 
A vila e o castelo de Outeiro manter-se-ão na Casa de Bragança até ao reinado de D. João II, altura em que, acusado de conspiração contra o monarca, D. Fernando, 3. ${ }^{\circ}$ duque de Bragança, é executado e todos os seus bens são confiscados pela Coroa. Em 18 de junho de 1496, D. Manuel I reabilita a casa ducal, restituindo todos os bens da antiga casa ducal ao filho de D. Fernando, o duque D. Jaime. O último e $8 .^{\circ}$ duque de Bragança será D. João, que em 1640 será aclamado rei de Portugal, iniciando a

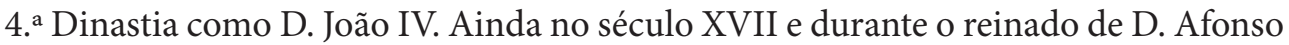
VI a Casa de Bragança será anexada pela Coroa ${ }^{277}$.

Durante a vida do 3..$^{\circ}$ duque de Bragança, D. Fernando, o domínio da Casa de Bragança chegou a ocupar $17,3 \%$ do território português, espalhando-se por quase todo o reino e ocupando zonas de grande importância económica. Por esta altura os Braganças senhoreavam 17 dos 89 concelhos com assento nas cortes ${ }^{278}$.

Este grande domínio territorial foi também secundado por direitos judiciais, o que causou grandes protestos por parte dos concelhos. Para além disso, os Braganças detinham também extensos direitos de administração militar, controlando muitas alcaidarias-mores, entre elas a de Bragança e de Outeiro. Recolhiam os impostos dos concelhos sob a sua jurisdição, com a condição de se responsabilizarem pelo pagamento das obras e reparações nas fortalezas e centros urbanos. A seu cargo ficava também a manutenção das praças, com efetivos e comando das tropas ${ }^{279}$.

Esta delegação de poderes na Casa de Bragança foi intencional e terá sido a forma encontrada pela Coroa para dinamizar e manter a defesa de zonas de fronteira como Trás-os-Montes.

Reconhecidas as dificuldades em manter estas praças ativas, os monarcas dos finais da Idade Média, delegaram responsabilidades nestas grandes famílias, contando com a sua fidelidade e empenhamento.

\subsection{INTERVENÇÕES MILITARES EM QUE O CASTELO DE OUTEIRO ESTEVE ENVOLVIDO}

Segundo Jorge Borges de Macedo havia três principais métodos de guerra na Idade Média: os cercos, ou ações partindo de castelos; os confrontos dispersos, tipo guerrilha; e a pilhagem e destruição de colheitas $^{280}$. Não sabemos ao certo onde se encaixam os confrontos em que o castelo de Outeiro esteve envolvido, pois não é claro que tenha sido cercado, que tenha sido alvo de ações de guerrilha ou que tenha havido pilhagem e destruição dos bens da sua povoação.

\footnotetext{
277 MENDONÇA, 1995: 243.

${ }^{278}$ CUNHA, 1990: 102.

${ }^{279}$ CUNHA, 1990: 117.

${ }^{280}$ MACEDO, 1991: 406.
} 
Pelos documentos que analisamos, ficamos com a certeza que a população não se sentia segura. Encostados à fronteira, próximos de zonas de comunicação entre os dois reinos, as gentes de Outeiro viveriam em constante sobressalto, aflitas com as notícias de guerras e sofrendo com os ataques desferidos.

Eram poucos os que escolhiam a vila para assentar. Os que ficavam, julgavam-se mais seguros a viver junto ao castelo, daí os pedidos insistentes para se construir uma cerca. Para além do medo da guerra, havia ainda as obrigações e os encargos militares. $\mathrm{O}$ custo de ter que se defender a terra e o castelo com as armas que encontravam. Destas histórias não se fizeram registos, mas podemos inferi-las pela documentação.

A ameaça era real pois o castelo de Outeiro fazia parte da primeira linha de defesa da fronteira com Castela. Do alto das suas torres era possível vigiar as entradas no reino português e a via que, passando no planalto transmontano, ligava Bragança a Vimioso.

Marco e sentinela de fronteira, o castelo de Outeiro viu-se envolvido em alguns conflitos que tanto defendiam os interesses de Portugal como os de Castela.

Depois da primeira notícia documental, datada de $1361^{281}$, em que se dá conta da existência do castelo de Outeiro, a fortaleza poderá ter estado envolvida num conflito em 1369, que opôs D. Fernando, rei de Portugal, a D. Henrique II de Castela. $\mathrm{O}$ alegado ataque ao castelo de Outeiro por parte das tropas do rei castelhano surge no contexto da campanha que levou D. Fernando a invadir e tomar algumas praças na Galiza em 1369. Depois desta incursão, o monarca volta para Coimbra. Em resposta, D. Henrique II de Castela entra em território português e toma a cidade de Braga, seguindo depois para Guimarães, onde põe cerco à cidade. Enquanto resiste, o alcaide de Guimarães pede auxílio a D. Fernando, que decide rumar ao norte, passando pelo Porto e recrutando mais homens para enfrentar o rei castelhano. Contudo, antes da chegada de D. Fernando, o rei castelhano levanta o cerco a Guimarães e decide retirar para Castela, pois terá recebido notícias de ataques a Algeciras, sendo necessário o reforço de tropas nessa região ${ }^{282}$.

$\mathrm{Na}$ retirada para Castela, D. Henrique II ruma para leste e, segundo Fernão Lopes, «foisse pera aquella comarca, e tomou Vinhaaes, e Bragamça, e Çadavj, e o outeiro de Miranda, em muj poucos dias ${ }^{283}$. Segundo a bibliografia consultada

\footnotetext{
${ }^{281}$ Chancelarias Portuguesas: D. Pedro I (1357-1367), 1984: 268.

${ }^{282}$ GOMES, 2009: 94. Ainda segundo a autora, Algeciras era um ponto estratégico estando «em causa o controlo do Estreito, outro ponto estratégico fundamental, a par de Sevilha, numa guerra que se combatia também por mar». ${ }^{283}$ LOPES, 1966: cap. XXXV, 96.
} 
parece haver consenso sobra as localidades tomadas: Vinhais, Bragança, «Çadavj» ${ }^{284}$, indicada como Cedovim, e «o outeiro de Miranda», como Outeiro de Miranda ${ }^{285}$.

No caso de Maria Helena da Cruz Coelho, a autora refere as localidades e apresenta um mapa com os itinerários das invasões. No mapa, a incursão do rei castelhano parece não passar por Outeiro de Miranda, seguindo de Bragança para Cedovim e daqui para Miranda do Douro, onde entraria em Castela ${ }^{286}$. Contudo, João Gouveia Monteiro apresenta, na Nova História Militar de Portugal, um outro mapa onde o monarca castelhano, depois de tomar Bragança, toma Cedovim e depois Outeiro, entrando aqui em Castela. $\mathrm{O}$ autor escreve ainda que: «Henrique II acabara por desistir de tomar Guimarães e batera em retirada para Castela, não sem aproveitar a viagem para tomar Vinhais, Bragança, Outeiro de Miranda e, eventualmente, Cedovim» ${ }^{287}$. Fica então a dúvida se Fernão Lopes se referia a Outeiro de Miranda, a Miranda do Douro ou, eventualmente, às duas.

Voltemos a Fernão Lopes, e retomemos a sua narrativa no ponto onde ele explica como as fortalezas transmontanas foram tomadas:

huuns forom tomados per arte, outros por se nom poderem defemder; assi como foi tomada Miramda, que ante que elRei Dom Hemrique cheguasse a ella, mudaromsse alguns seus, e fingeromsse que eram recoveiros Portugueses, e que aviam mester viandas da villa por seus dinheiros: os do logar nom se catamdo de tal arte, deromlhe logar que emtrassem dentro; e elles emtramdo, teverom loguo a porta, e em isto chegarom apressa os que hiam acerca pera lhe acorrer, e desta guisa ouverom a villa ${ }^{288}$.

O cronista conta como se tomou a vila de Miranda, remetendo-nos novamente para a questão anterior: "Miranda» é Miranda do Douro ou Outeiro de Miranda? Estaria a referir-se a Miranda do Douro, e daí o mapa apresentado por Maria Helena da Cruz Coelho ${ }^{289}$ ?

\footnotetext{
${ }^{284}$ No endereço electrónico http://www.visitarportugal.pt, onde se faz um apanhado da história de Cedovim, transcreve-se o foral concedido por D. Afonso III em 1271 à localidade de «Cedavj». A forma de escrever o nome da vila é idêntica à que escreveu Fernão Lopes, sendo possível tratar-se, de facto, da mesma localidade.

${ }^{285}$ Bibliografia consultada em que se faz coincidir «Çadavj» a Cedovim (concelho de Vila Nova de Foz Coa) e «o outeiro de Miranda» a Outeiro de Miranda: PERES, 1969: 210-220; ALVES, 2000: I, 63; VERDELHO, 2000: 75; MONTEIRO, 2003: 252; BARATA, TEIXEIRA, dir., 2003: 252-253; COELHO, 2008: 34; GOMES, 2003: 201 e GOMES, $2009: 94$. ${ }^{286}$ COELHO, 2008: 34-35. A autora refere no texto Outeiro de Miranda, mas no mapa apresentado, que teve como fonte TAVARES, 1983: 50, faz com que a incursão castelhana passe de Bragança para Cedovim e depois para Miranda do Douro.

${ }^{287}$ BARATA, TEIXEIRA, dir., 2003: 252-253. No texto intitulado As campanhas que fizeram a história, João Gouveia Monteiro, apresenta um mapa cuja fonte foi: SERRÃO, MARQUES, dir., 1987: 513.

${ }^{288}$ LOPES, 1966: cap. XXXV, 96.

${ }^{289}$ COELHO, 2008: 433. A autora refere TAVARES, 1983: 45-89, como fonte do mapa que apresenta.
} 
Independentemente de Fernão Lopes se referir a Miranda do Douro ou a Outeiro de Miranda, não podemos deixar de estranhar, como João Gouveia Monteiro, o itinerário do rei castelhano, que tendo como intenção dirigir-se para Algeciras, levanta o cerco a Guimarães, e vai tomar Vinhais, Bragança, seguindo depois para Cedovim, na margem esquerda do Douro, para de seguida voltar para norte e tomar Miranda do Douro.

Retomemos, mais uma vez, a narrativa de Fernão Lopes, que relatando o pânico das populações, acrescenta que «todollos montes daquela comarca forom estomce cheos de homeens, e molheres, e moços, gaados, e viverom na Abadia velha, e em Ventosello, e em todallas aldeas dos montes altos; e todollos monges e abades dos moesteiros daquella comarca todos fugirom, e foi esto do mês dagosto ataa Samta maria de Setembro» ${ }^{290}$. A este final de Fernão Lopes, Rita Costa Gomes acrescenta na sua transcrição:

E deixou el-rei Dom Henrique recado na vila de Bragança, e foi-se pera Castela. E dizem que o azo de sua partida tão cedo, e de não atender el-rei Dom Fernando pera pelejar com ele, foi novas que lhe vieram sobre Guimarães, como a cidade de Aljeciras, por não ser posta em boa segurança, a cobraram os mouros e destruíram de todo, e que el-rei de Granada viera aí per seu corpo. E por o grão pesar que el-rei desto houve, se partiu assim e se foi pera a vila de Toro; e dali repartiu suas gentes à frontaria de Granada, e outras a Galiza, e delas contra Zamora, e aos outros lugares que não tinham sua voz e estavam por Portugal291.

A crónica de Fernão Lopes faz referência à localidade de Ventozelo que se localiza muito próxima da margem direita do rio Douro, hoje integrada no concelho de Mogadouro. Quando o cronista escreve sobre o temor das populações e que estas se refugiaram na abadia, nos montes altos e em Ventozelo, podemos inferir que as tropas castelhanas terão passado ali perto, portanto junto à raia, possivelmente do lado leste da serra de Mogadouro, percurso que, poderia ter passado por Miranda do Douro.

Por outro lado, Rita Costa Gomes acrescenta que D. Henrique II, antes de retirar para território castelhano deixa recado na vila de Bragança. Depois partiu para Castela, concretamente para a vila de Toro, um pouco a leste de Zamora. Em Toro repartiu as suas tropas, rumando umas para Granada, outras para a Galiza, outras para Zamora e para outros lugares que tinham voz por Portugal. Segundo o texto o

\footnotetext{
${ }^{290}$ LOPES, 1966: cap. XXXV, 96.

${ }^{291}$ GOMES, 2009: 258. Ver advertência na nota de rodapé 97, sobre a origem do texto transcrito.
} 
monarca castelhano poderá ter voltado a Bragança e seguiu depois para Toro. Sabemos que Zamora tinha tomado partido por D. Fernando, daí a preocupação do rei castelhano em tomar a cidade. No reino de Portugal e junto à fronteira, D. Henrique II já tinha tomado as principais cidades, como Bragança, e eventualmente, Miranda do Douro. Daí ser possível que tenha conquistado também o castelo de Outeiro, passando a controlar a fronteira transmontana.

Concluindo, pensamos que em 1369, o castelo de Outeiro de Miranda foi tomado pelos castelhanos, como o foram o castelo de Bragança e, ao que tudo indica, o de Miranda do Douro. Este parece ter sido o primeiro e único ataque ao castelo de Outeiro em época medieval, relatado pelas fontes.

Durante o reinado de D. João I, e por causa da crise dinástica em que Portugal se viu mergulhado após a morte de D. Fernando, Trás-os-Montes terá tomado partido por D. Beatriz e consequentemente por Castela. Por esta razão o monarca de Avis e o Condestável Nuno Álvares Pereira tiveram que reconquistar várias praças transmontanas entre 1385 e 1386, nomeadamente, Chaves e Bragança. Contudo, as fontes são omissas em relação ao castelo de Outeiro de Miranda.

Outros conflitos se travaram durante o reinado de D. João $\mathrm{I}^{292}$, envolvendo os castelos de Vinhais, Piconha, Bragança e Miranda do Douro. Porém, nunca se refere o de Outeiro de Miranda, que parece ter tido um papel secundário em todo este processo de afirmação territorial, dependendo, provavelmente, da sorte das praças principais como Bragança e Miranda do Douro. Estas eram de facto, os pontos urbanos que interessavam conquistar para subsequentemente controlar o restante território.

O castelo de Outeiro de Miranda voltará às páginas da história durante a Guerra da Restauração. Os conflitos alastraram-se a Trás-os-Montes em 1641, com invasões espanholas a Monforte de Rio Livre, Vinhais e Miranda do Douro.

Os castelos tinham que estar preparados por isso as igrejas da diocese de Miranda foram intimadas em 1641 a contribuírem com «donativos», para ajudarem no financiamento das despesas dos conflitos com Castela, nomeadamente na reedificação dos muros de Vinhais e Monforte de Rio Livre ${ }^{293}$. Com a mesma preocupação de reforçar as praças transmontanas damos conta de um documento, datado de 1642, onde se refere a aquisição de peças de artilharia para as praças de Bragança, Monforte de Rio Livre e Outeiro:

\footnotetext{
292 GOMES, 2003: 201.
}

${ }^{293}$ ALVES, 2000: IV, 478. 
Pareseme muito bem o assento que V. M.es tem tomado para se vir buscar a artelharia assi para o que esse povo da dinheiro para se comprar, como para a que El Rei tem mandado para essas fronteiras que ainda que não nomeam que vem nenhuma para essa cidade a mim me parese muito bem ficarem coatro pessas das que vem, nela, e hüa ha de vir para Monforte, e outra para o castello de Outeiro ${ }^{294}$.

A preocupação em equipar a praça de Outeiro parece fundamentada, pois em 1646 uma incursão espanhola destrói a vila de Outeiro. Segundo Abade do Baçal

os galegos, aproveitando as favoráveis circunstâncias da doença do governador e falta de gente, comandado pelos mestres de campo D. Francisco de Castro, que assistia em Puebla de Sanábria, e D. Francisco Geldres, governador de Zamora, com seis mil homens de infantaria, quatrocentos de cavalaria e três peças de artilharia, invadiram o termo da vila de Outeiro, não poupando coisa alguma das que uma soldadesca desenfreada costuma semear ${ }^{295}$.

Apesar do ataque que obrigou a população a refugiar-se no castelo,

o novo governador convoca à pressa a gente que devia pegar em armas, mas pouco efeito produzem seus chamamentos: apenas pôde congregar setecentos homens de infantaria e cento e dez de cavalaria. Manda adiante o comissário geral Achin de Tamericurt, valoroso francês que muito se distinguiu ao serviço de Portugal, para dar algum alento aos refugiados no castelo de Outeiro, junto dos muros do qual sustenta valorosa escaramuça com o inimigo ${ }^{296}$.

De Outeiro os soldados espanhóis rumam à cidade de Bragança onde vão acampar. Nos anos 50 do mesmo século, os ataques sucederam-se em território de Miranda e Bragança, espalhando o pânico entre as populações ${ }^{297}$. Segundo Rita Costa Gomes «as destruições do século XVII foram particularmente importantes em Outeiro, Bragança e Santo Estêvão na veiga de Chaves» ${ }^{298}$.

Um século depois, o castelo de Outeiro e a sua povoação veem-se novamente envolvidos em guerras com Espanha, desta vez por causa da Guerra dos Sete Anos. Comandados pelo Tenente General Marquês de Caballos, o destacamento espanhol saiu de Alcañices e ocupou o castelo, que estava abandonado, e a vila de Outeiro,

\footnotetext{
${ }^{294}$ ALVES, 2000: XI, 124-125.

${ }^{295}$ ALVES, 2000: I, 90.

296 ALVES, 2000: I, 90.

${ }^{297}$ GOMES, 2003: 201.

298 GOMES, 2003: 114 .
} 
no dia 13 de maio de 1762. Depois terão queimado as portas e todas as madeiras existentes $^{299}$. Segundo Francisco Felgueiras, os invasores teriam ainda obrigado os moradores dos termos a colaborarem nos trabalhos de «fornilhos e minas, para a destruição do castelo e das muralhas circundantes» ${ }^{300}$.

Pelo que ficou exposto, o castelo de Outeiro terá ficado bastante destruído em 1762. Não temos notícia de que a fortaleza tenha sido restaurada depois desta data. Contudo, e já referentes ao século XIX recolhemos alguns dados sobre a fortaleza.

Segundo nos diz Francisco Felgueiras, a fortaleza raiana teria pelo menos três peças de artilharia. Uma está junto à igreja de Santo Cristo, na vila, outra estará no Museu Militar de Bragança e outra foi levada pelas tropas francesas em 1808 e abandonada próxima de Puebla de Sanábria ${ }^{301}$. Nas Invasões Francesas a vila de Outeiro terá sido intimada para pagar, mais uma vez, as despesas da guerra ${ }^{302}$.

Durante as Guerras Liberais, e segundo o Abade de Baçal,

a 4 de Março de 1827 entrava Correia de Melo em Bragança em perseguimento das tropas absolutistas que a haviam abandonado no dia anterior, retirando sobre Outeiro... À vista disto, para impedir nova entrada dos inimigos em território português, retrogradou Vila Flor por Argozelo para Bragança e Correia de Melo foi ocupar Outeiro ${ }^{303}$.

Não é claro se nos inícios do século XIX ainda existiria alguma estrutura no castelo capaz de albergar tropas, contudo é possível que as ruínas da fortificação ainda fossem usadas em manobras militares. Apesar de destruído, as ruínas do castelo de Outeiro continuariam a sugerir a sua função militar, pois no "ano de 1846, quando estava em marcha a revolução da Maria da Fonte, acamparam junto a Outeiro as tropas do futuro Conde de Vinhais, Manuel da Costa Pessoa» ${ }^{304}$.

\footnotetext{
${ }^{299}$ MANSO PORTO, 1999: XXXVII.

${ }^{300}$ FELGUEIRAS, 1968: 11.

${ }^{301}$ FELGUEIRAS, 1968: 10.

302 ALVES, 2000: I, 184.

${ }^{303}$ ALVES, 2000: I, 187.

${ }^{304}$ FELGUEIRAS, 1968: 11.
} 
5

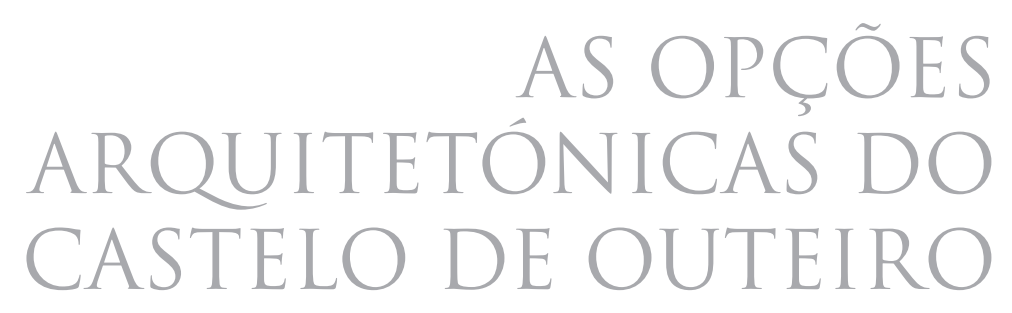



Não sendo uma realidade estanque, o castelo de Outeiro foi-se adaptando às exigências dos tempos, obedecendo a conjunturas político-militares e a condicionalismos regionais e nacionais.

Como castelo de fronteira, e posicionando-se muito próximo da linha divisória entre os reinos de Portugal e Castela, Outeiro ganhou relevo durante a guerra de 1369, que opôs Portugal a Castela, e terá atingido o seu apogeu durante o domínio da Casa de Bragança. Embora tenham havido dificuldades com a sua manutenção, a fortaleza viu-se ainda envolvida na Guerra da Restauração, acabando por ser destruída já em pleno século XVIII. Desde esses tempos até hoje, restou-lhe o abandono e a ruína, que vão camuflando a sua aura altaneira de outrora.

Esta memória física, que marcou, e marca ainda, a paisagem bragançana, pode ser reconstituída através da cartografia que ao longo dos anos foi produzida, permitindo uma imagem da sua estrutura e das suas alterações.

No caso do castelo de Outeiro, temos o privilégio de poder comparar plantas que foram desenhadas em épocas diferentes, permitindo-nos assim uma análise evolutiva e temporal do castelo. O seu estudo passa, indubitavelmente, pelo exame destas plantas que nos dão conta da sua longa existência. Este exercício de observação e comparação permite-nos aferir as suas alterações, acrescentos ou permanências que muito nos dizem sobre a sua importância e/ou decadência.

Para além das plantas desenhadas em tempos anteriores, apresentamos uma planta com as estruturas que, in situ, nos foi possível observar, tomando como base a última planta desenhada, datada de 1762 .

Por fim, tentaremos sistematizar as principais conclusões que consideramos pertinentes para a compreensão do castelo.

\subsection{A REPRESENTAÇÃO DO CASTELO DE OUTEIRO NOS DEBUXOS DE DUARTE DE ARMAS}

Um dos testemunhos mais elucidativos da preocupação dos monarcas com a defesa da fronteira portuguesa é o Livro das Fortalezas de Duarte de Armas. É curioso como este registo extraordinário dos castelos da raia surge num momento de tranquilidade entre os dois reinos e depois de um tratado de paz ${ }^{305}$ onde se acordou que, ambos os reinos, se comprometiam a derrubar todas as fortalezas que tinham sido feitas na fronteira. Embora tenham sido derrubadas algumas estruturas, D. João II não deixará de mandar reparar e «prover» as cidades, vilas e castelos dos «extremos de seus reinos» ${ }^{306}$.

\footnotetext{
305 «O tratado de paz foi celebrado entre D. Afonso V e seu filho D. João e os Reis Católicos, confirmado em Toledo a 6 de Março de 1488». ARMAS, 2006: 4.

${ }^{306}$ ARMAS, 2006: 4.
} 
Esta preocupação de reforçar a defesa da fronteira foi herdada por D. Manuel I, que em 1502, e com a contribuição do povo, manda fazer muros, torres e barreiras em vários castelos de Portugal ${ }^{307}$. Paralelamente, e ainda durante esta primeira década de Quinhentos, talvez por volta de 1509, o monarca encarregou o seu escudeiro, Duarte de Armas, de vistoriar as fortalezas da primeira linha de defesa do reino e registar o seu estado de conservação. Este trabalho foi executado pelo escudeiro, que partiu com o criado, percorrendo a maioria das fortalezas raianas, desde Castro Marim a Caminha, elaborando desenhos de plantas e, pelo menos, duas vistas panorâmicas de cada castelo ${ }^{308}$.

Deste monumental trabalho resultariam dois exemplares: os códices A e B, que teriam sido depositados na Torre do Tombo e que lá se terão mantido até 1655. Depois desta data, o códice B desapareceu, encontrando-se hoje na Biblioteca Nacional de Madrid. Este último exemplar encontra-se truncado e os desenhos das vistas «podem considerar-se esboços mais aperfeiçoados do que os preliminares, mas ainda imperfeitos por não representarem muitos pormenores relativos ao aspecto das construções e à paisagem onde se achavam integradas» ${ }^{309}$.

Será com este precioso registo de Duarte de Armas que iniciaremos o nosso exame às opções arquitetónicas do castelo de Outeiro. Os desenhos do escudeiro de D. Manuel I são, até à data, os únicos registos da fortaleza dos finais da Idade Média, resultando de importância capital para o seu estudo.

A nossa análise terá como base principal os desenhos editados na obra que temos vindo a citar ${ }^{310}$, que teve como fonte o códice em pergaminho guardado na Torre do Tombo e, sempre que seja pertinente, serão cotejadas as diferenças observadas nos desenhos das vistas panorâmicas de Outeiro que constam do códice B.

Nas vistas que Duarte de Armas desenhou por volta de 1509 podemos observar que o castelo de Outeiro se encontrava em bom estado de conservação, mantendo intacto todo o seu perímetro, onde se elevavam duas torres, sendo uma delas a de menagem. Toda a estrutura militar foi construída sobre uma crista de afloramentos irregulares. Virada à fronteira, o escudeiro desenhou a cerca da vila, que na altura se encontrava concluída (Desenhos 1, 2, 3, 4).

O segundo pormenor a destacar nestas vistas é o paço, que parece ter mais do que um corpo, e que serviria para albergar o alcaide, talvez uma pequena guarnição, poderia ter uma cadeia e instalações para guardar o que era necessário à manutenção da praça. Destas construções erguem-se duas chaminés ${ }^{311}$, indicadores de conforto,

\footnotetext{
307 ARMAS, 2006: 5.

308 ARMAS, 2006: 1.

309 ARMAS, 2006: 1 .

310 ARMAS, 2006. Com introdução de Manuel da Silva Castelo Branco.

${ }^{311}$ Nas vistas do códice B, que se encontra em Espanha, apenas é representada uma chaminé.
} 
e várias aberturas nos pisos superiores, sobretudo do lado oeste, voltado à aldeia. Estes vãos são representados com duas tipologias: a mais numerosa, com dintel em arco, que se distribui sobretudo pelas casas do paço e pela torre de menagem; e as que têm dintel reto, que são representadas na torre «interior» e junto à porta de entrada no castelo ${ }^{312}$. Salientamos uma janela voltada a leste, gradeada, provavelmente a cadeia. Os telhados das construções no interior do pátio são, maioritariamente, de duas águas e parecem ser cobertos com telha.

Continuando com a observação das vistas sobre o castelo, realcemos agora os elementos de carácter militar. Primeiro as torres, em número de duas: a torre de menagem, próxima da porta de entrada no castelo, foi construída no exterior da muralha, em silharia ${ }^{313}$, com três janelas viradas a poente e duas a nascente ${ }^{314}$, todas com dintel em arco; a segunda torre ergue-se também em silharia, no interior do recinto muralhado, apresentando uma única janela quadrangular voltada a poente. Ambas as torres são coroadas com ameias pentagonais. Na torre do interior do recinto fortificado faltam algumas ameias, que parecem ter caído.

A entrada no castelo é desenhada voltada a sul e faz-se por porta com arco em volta perfeita, também ele construído em silharia, possivelmente de granito. Por cima da entrada existe um balcão que foi desenhado coberto.

Ainda a propósito da entrada no castelo de Outeiro, observamos, na vista panorâmica oeste, que esta se encontrava protegida por um muro em $\mathrm{L}^{315}$, coroado com ameias pentagonais. Este antemuro obrigava, a quem subia pelo lado da aldeia, a contorná-lo a sul, impedindo uma entrada direta na fortaleza.

Na vista E-NE, é representada uma outra porta que dá acesso a uma estrutura baixa, com três troneiras cruzetadas e que parece uma barbacã. Esta estrutura fica voltada a leste e parece encostar ao torreão coberto e à torre de menagem. Sensivelmente por baixo do torreão e ao lado da barbacã, Duarte de Armas escreve "porta falsa». Esta porta abre-se para o interior da cerca da vila.

\footnotetext{
312 Mais uma vez as vistas dos desenhos de Madrid apresentam algumas diferenças nas janelas, não em relação ao seu dintel, que coincidem no essencial, mas no número. Neste exemplar a torre «interior» não tem qualquer abertura visível e a torre de menagem apresenta apenas uma janela voltada a leste, enquanto na vista do manuscrito que se conserva em Portugal são visíveis duas janelas paralelas no último andar.

${ }^{313}$ Segundo as vistas desenhadas pelo Duarte de Armas no códice A, as duas torres, o arco da porta de entrada e as juntas das construções são desenhadas com pequenos retângulos, sugerindo silhares, talvez em granito. Os panos das muralhas e restantes muros são representados lisos, podendo insinuar que eram construídos com outros materiais, nomeadamente rochas metamórficas oriundas da região.

${ }^{314}$ Como já referimos, no códice B, a face da torre de menagem voltada a nascente apenas tem uma janela. Observamos ainda que os alçados das construções são incaracterísticos, não se destacando nenhuma parte com silharia, como acontece no exemplar da Torre do Tombo.

${ }^{315} \mathrm{Na}$ vista guardada no códice B, que está em Madrid, o muro que enquadra a porta não parece ter a configuração em L, como nos desenhos da Torre do Tombo, correndo direito e paralelo à muralha, estendendo-se para sul e muito para além da fortificação.
} 
A muralha do castelo encontra-se reaproveitada, em grande parte, nas construções do paço, apresentando-se desimpedida na metade norte, sendo aqui coroada com ameias quadrangulares. Na extremidade noroeste, vê-se uma construção em madeira, a que Duarte de Armas chama «necesaryas», ou seja, latrinas. João Gouveia Monteiro parece considerar esta estrutura como um hurdício, pois escreve:

em mais de metade dos debuxos (mais precisamente em pelo menos 31 desenhos) surgem representações de hurdícios ou de balcões, sendo curioso registar que a maioria dessas representações diz respeito a castelos situados nas províncias tradicionais de Trás-os-Montes (10 casos) e da Beira (9 casos). Assim, reconhecemos a presença de hurdícios na muralha de Outeiro de Miranda ${ }^{316}$.

Finalmente, e ainda sobre as vistas panorâmicas de Duarte de Armas, uma nota para a cerca da vila, que julgamos ser a que os moradores pediram para construir em 1355 e que, apenas lhes foi concedida autorização em 1414, por D. João I. A cerca define uma plataforma inclinada a leste do castelo, formando um espaço mais ou menos ovalado e vazio de construções. Tem duas portas, uma a norte e outra a sul, e apresenta umas escassas ameias quadrangulares na vista oeste, dando a entender que teriam sido destruídas.

A planta do castelo de Outeiro, desenhada por Duarte de Armas, representa apenas o recinto do castelo e os arranques, a norte e a sul, da cerca da vila. O traçado da muralha parece ter sido condicionado pela topografia do terreno, apresentando uma configuração irregular ${ }^{317}$. Na metade norte, o castelo tem uma planta que parece ovalada e na metade sul as estruturas formam uma planta retangular, sugerindo a imagem de duas fortalezas diferentes coladas (Plantas 1 e 2).

Sobre a muralha, Duarte de Armas escreve no desenho: «Esta fortaleza tem toda em redondo tirando hu baluarte e a torre da menagem $86 \mathrm{v} 3 \mathrm{p}$ e a grosura dele $2 \mathrm{v}{ }^{318}$, isto é, o muro defensivo mediria em todo o seu perímetro 95,26 $\mathrm{m}$ e teria de largo 2,20 $\mathrm{m}^{319}$. Como já referimos a propósito das vistas, a muralha tinha um balcão construído em madeira destinado a latrina voltado sensivelmente a noroeste, não apresentando nenhum torreão, à exceção do torreão coberto do lado sudeste, encostado ao «baluarte» (barbacã) e à torre de menagem (Planta 3).

\footnotetext{
${ }^{316}$ MONTEIRO, 1999: 81.

${ }^{317}$ MONTEIRO, 1999: 53.

${ }^{318}$ Sobre a explicação das medidas do Duarte de Armas ver: ARMAS, 2006: 19. Manuel da Silva Castelo Branco esclarece que o $v$ corresponde a vara $(1,10 \mathrm{~m})$ e o $p$ a palmo $(0,22 \mathrm{~m})$. Quando o escudeiro escreve uma medida «em que ao número de varas se segue o sinal mais», como por exemplo $12 \mathrm{v}+$, quer dizer 12 varas e meia.

319 MONTEIRO, 1999: 56. O autor refere as medições de Duarte de Armas para o castelo de Outeiro, acrescentando que mais de $60 \%$ dos castelos desenhados pelo escudeiro não tinham mais de 100 a $200 \mathrm{~m}$ de perímetro, resultando numa área muito pequena.
} 
Analisando a muralha sob a perspetiva de uma construção gótica, deveremos dizer que ela não se enquadra bem nos padrões das fortalezas deste género, pois é quase desprovida de torreões, que a espaços regulares, a protegiam dos ataques inimigos ${ }^{320}$. Contudo, devemos realçar que o castelo de Outeiro foi construído sobre um maciço rochoso que, só por si, dificultava a aproximação de tropas ou engenhos às muralhas. O único sítio mais vulnerável seria a zona sul, e talvez por isso se tenha erguido o torreão quadrangular que, nos desenhos do Duarte de Armas, aparece coberto.

Do adarve ou das escadarias que lhe dariam acesso não temos qualquer informação. Contudo deveriam existir, pois havia uma latrina, cujo acesso poderia ser feito através de um adarve.

Para além do traçado da muralha do castelo de Outeiro, também as duas torres que se erguem acima das muralhas e das construções nos colocam questões interessantes.

Uma delas é identificada por Duarte de Armas como «menagem», construída no extremo sul e fora do perímetro das muralhas. Segundo o escudeiro de D. Manuel I, «Esta torre da menagem tem quatro vaãos e tem daltura $16 \mathrm{v} »$. Indica no interior da planta as suas medidas: « $5 \mathrm{v} » \mathrm{e}$ « $3 \mathrm{v}+»$. A torre de menagem teria então uma planta de $5,50 \mathrm{~m} \mathrm{x} \mathrm{3,85} \mathrm{m,} \mathrm{com} \mathrm{cerca} \mathrm{de} 21,175 \mathrm{~m}^{2}$ de área e mediria de altura 17,60 m e teria quatro andares.

A outra torre é designada pelo autor quinhentista, simplesmente como «torre». Ergue-se no interior da praça, sensivelmente a meio, e tem como legenda «Esta torre tem tres vaãos e daltura $15 \mathrm{v}+$ e a grosura do muro dela $1 \mathrm{v}+»$. Quanto à sua planta é indicado que tem «3v 4p» e «3v 4p». Percebemos então que a torre tem 17,05 m de altura, três andares, paredes com 1,65 m de espessura e uma planta quadrada de 4,18 x 4,18 m, com 17,47 $\mathrm{m}^{2}$ de área (Planta 4).

A torre de menagem do castelo de Outeiro integra-se bem no conceito de defesa ativa, que Mário Jorge Barroca aponta. $\mathrm{O}$ autor diz que estas estruturas vão sofrer alterações substanciais, não só a nível da planta, que a partir de D. Dinis aparecem também com desenho poligonal, como serão deslocadas

para junto da muralha, aproximando-se das zonas onde a defesa era mais sensível e difícil [...] Mas o expoente máximo desta nova confiança são as torres de menagem erguidas no exterior dos castelos [...]. Esta implantação, impensável aos olhos do construtor românico, é afinal o corolário de todo este processo de afirmação da capacidade de defesa do castelo gótico ${ }^{321}$.

\footnotetext{
${ }^{320}$ BARROCA, 2003a: 119.

${ }^{321}$ BARROCA, 2003a: 119-120.
} 
De facto, a torre de menagem do castelo de Outeiro, não só foi erguida na zona de defesa mais vulnerável, a entrada, como foi construída fora do perímetro muralhado. Neste sentido, este elemento emblemático do castelo medieval foi planeado segundo os parâmetros mais avançados do castelo gótico, enquadrando-se bem na cronologia de Trezentos.

Já a segunda torre, a que se ergue no meio da praça, parece destoar desta filosofia inovadora. Ligeiramente mais baixa do que a torre de menagem apresenta uma planta quadrada e apenas um vão visível, com formato quadrangular, que presumimos abrir-se no último andar. Tem apenas três pisos e foi coroada com ameias poligonais, como a sua congénere.

A leste desta torre central, localiza-se a cisterna sobre a qual Duarte de Armas escreve: «Esta cysterna tem de vaãos 3v 1p». Isto é, teria 3,52 m de vão.

Relativamente à entrada no castelo de Outeiro, e segundo a planta do escudeiro de D. Manuel I, haveria duas soluções. A primeira, e inequívoca, é a que se abre a sudoeste, resguardada pelo antemuro. Sobre esta, Duarte de Armas escreve: «Entrada da porta com hua guaryta em cyma». De facto, e como já referimos quando falamos sobre as vistas panorâmicas, esta porta está protegida por um balcão com matacães, coberto, a que o escudeiro chama guarita. A segunda entrada, que nos suscitou algumas dúvidas, foi construída a sudeste, enquadrada diretamente pela torre de menagem e protegida por aquilo que o escudeiro chama «baluarte» ${ }^{322}$ e que nós chamamos barbacã de porta. Sobre esta estrutura Duarte de Armas escreve na legenda: «Tem este baluarte $6 \mathrm{v}$ e grosura dele $2 \mathrm{v}$ », isto é, tem 6,60 $\mathrm{m}$ de perímetro e 2,20 m de espessura de muros. A entrada neste espaço faz-se pelo recinto cercado da vila, sendo barrada à direita por um muro que se ergueu no interior. A barbacã tem ainda quatro troneiras cruzetadas (Planta 5).

Esta entrada levanta-nos algumas dúvidas, sobretudo porque na vista panorâmica E-NE do códice $\mathrm{A}^{323}$, Duarte de Armas escreve «porta falsa» (porta da traição). $\mathrm{Na}$ planta que estamos a analisar e que se encontra no mesmo códice, não se faz qualquer referência a uma porta falsa. Analisando esta entrada no castelo, reparamos que o acesso se faria pelo torreão coberto, através de duas portas, uma em frente à outra, sendo necessário atravessá-lo. Duarte de Armas não nos dá indicação sobre o torreão, mas sabemos que ele não se elevaria acima da muralha, estaria coberto

\footnotetext{
${ }^{322}$ Na definição moderna que o glossário da História das Fortificações Portuguesas no Mundo dá para baluarte, lê-se: «Embora a palavra surja no século XV, o sentido de plataforma pentagonal dimensionada para a artilharia de fogo só se fixa no final do seguinte. É uma obra avançada do reparo delineada com quatro lados e três ângulos exteriores além de dois que forma com as cortinas.» MOREIRA, dir., 1989: 328. No Dicionário de Arquitectura Militar acrescenta-se que «Duarte d’Armas e outros autores do início do séc. XVI, numa época em que a nova terminologia da fortificação abaluartada ainda não era muito clara, utilizam o termo baluarte para designar qualquer obra fortificada». NUNES, 2005: 58. Será baseado neste autor que João Gouveia Monteiro considera que o «baluarte» do castelo de Outeiro mais não é do que uma barbacã de porta. MONTEIRO, 1999: 42.

${ }^{323}$ No códice $B$, de Madrid, a vista que equivale a esta não tem legenda nesta porta.
} 
com telhado de quatro águas e, proporcionalmente às outras torres, teria uma planta mais pequena do que a torre do interior da praça. A entrada no castelo através do torreão era «barrada» por um ângulo da muralha. Coroando o torreão havia dois balcões com matacães para proteger a entrada na barbacã e a passagem pelo torreão.

Nas legendas da planta, Duarte de Armas apenas indica uma entrada, a que ficava resguardada pelo antemuro, reservando para a entrada voltada à cerca da vila, uma única observação ao «baluarte». Ao que tudo indica, a "porta falsa», ou porta da traição, deu lugar a uma entrada «abaluartada», reformada possivelmente depois da construção da cerca da vila. No início do século XVI, o castelo de Outeiro tinha duas entradas: uma voltada a sul, protegida pelo antemuro e outra voltada à cerca da vila, protegida pelo «baluarte».

Apesar destas entradas apresentarem soluções algo complexas e pouco comuns, e de nos parecer «imprudente» estarem em funcionamento simultaneamente, não seria estranho aos castelos góticos terem mais do que uma porta. Segundo João Gouveia Monteiro, era natural haver uma porta virada à vila e outra aos arrabaldes, para além das portas da traição, herdadas dos castelos românicos, ou mesmo uma porta falsa. O mesmo autor acrescenta ainda que «por vezes as portas estão inscritas nas próprias torres; e quase sempre estão bem protegidas, não só por torreões como também por outros elementos defensivos, como balcões, matacães, troneiras, etc.» ${ }^{324}$, como será o caso da entrada voltada à cerca do castelo de Outeiro.

Apontadas as características mais significativas que Duarte de Armas desenhou do castelo de Outeiro, esmiucemos agora as dúvidas e questões que a análise das diferentes estruturas nos suscitaram.

Uma primeira conclusão é que o castelo de Outeiro não foi construído de uma só vez e segundo um único projeto. Como vimos, a planta do castelo, de forma irregular, aponta-nos para dois momentos diferentes que vão determinar todas as outras estruturas construídas e, consequentemente, o momento em que elas foram erguidas, remetendo-nos para as questões cronológicas.

Fixando-nos então na planta, podemos dividi-la em duas metades, analisando os elementos arquitetónicos de cada uma.

$\mathrm{Na}$ metade sul, que julgamos ser de uma fase mais recente, vemos claramente uma construção gótica que corresponde ao conceito de defesa ativa. Desta zona já fizemos referência à torre de menagem, erguida no exterior do perímetro muralhado, defendendo as entradas, e apontamos as dúvidas sobre as duas portas do castelo. Associadas às entradas, referimos também a barbacã e o antemuro, que protegem as portas e a própria torre de menagem, solução que se terá generalizado «na segunda

${ }^{324}$ MONTEIRO, 1999: 82-85. 
metade da centúria [de Trezentos] e ao longo do século XV» ${ }^{325}$. Finalmente, um apontamento para os balcões com matacães e as troneiras cruzetadas, esta, uma solução mais tardia, introduzida para adaptação ao uso da artilharia.

Duarte de Armas desenha no castelo de Outeiro, e nesta zona sul, quatro balcões com matacães, quase todos protegendo as entradas na fortaleza, situando-se uma já no interior da praça, junto à torre interior. Estas «soluções arquitectónicas petrificadas que visam permitir o tiro vertical» ${ }^{326}$ são, segundo Mário Jorge Barroca, «uma solução militar que, se não for de origem portuguesa [...], encontrou em Portugal o palco privilegiado de afirmação». Ainda segundo o autor, o exemplar mais antigo está datado de 1263 (Melgaço), mas a sua difusão terá ocorrido «com o vasto programa de reformas encetado por D. Dinis a partir dos fins da década de 80 do Séc. XIII». Primeiro terão surgido nas torres de menagem e depois alastraram-se às "portas de entrada dos castelos, melhorando a defesa desses pontos mais vulneráveis» ${ }^{327}$.

As troneiras surgem mais tarde e num contexto de adaptação dos antigos castelos medievais à pirobalística. Segundo Mário Jorge Barroca, e apesar de ainda não se ter definido o momento exato em que estes elementos surgiram entre nós, ele terá «ocorrido nos meados da centúria de Quatrocentos, em pleno reinado de D. Afonso $\mathrm{V}$, sendo, por isso, relativamente sincrónico do que se conhece para os restantes reinos ibéricos». Especifica ainda que «os primeiros exemplos de troneiras aparecem entre nós nos últimos anos da primeira metade do Séc. XV» sendo a sua difusão «seguramente um acontecimento da segunda metade dessa centúria, abrangendo a parte final do reinado de D. Afonso V mas também os de D. João II e D. Manuel» ${ }^{328}$. As troneiras do castelo de Outeiro poderão enquadrar-se na primeira fase desta adaptação, momento em que

as estruturas medievais receberam adaptações pontuais, indispensáveis para que fossem providas de armas de fogo [...]. Estas intervenções, ligeiras e económicas, consistiram, sobretudo, na introdução de troneiras: aberturas cónicas, por vezes duplamente abocinadas, numa primeira fase dotadas de um simples rasgo vertical (para mirada), mais tarde com rasgo em T ou, mais comummente, em cruz - as troneiras cruzetadas e as recruzetadas, tão vulgares nos nossos castelos raianos ${ }^{329}$.

Voltando agora a nossa análise para a metade norte da planta de Duarte de Armas, verificamos que as soluções arquitetónicas apresentadas não se enquadram

\footnotetext{
${ }^{325}$ BARROCA, 2003a: 120.

326 BARROCA, 1998: 816.

327 BARROCA, 1998: 817.

328 BARROCA, 2004b: 241.

${ }^{329}$ BARROCA, 2004b: 240.
} 
na lógica do castelo gótico, mas aproximam-se mais do castelo românico. Senão vejamos: a muralha ergue-se com planta ovalada e sobre os afloramentos, adaptando-se ao relevo da penedia. Esta zona do castelo é dominada pela torre interior, cuja estrutura se enquadra no conceito de torre de menagem românica. Segundo Mário Jorge Barroca, a definição de um estereótipo para este tipo de torre seria «uma torre quadrada, com 7 a 8 metros de lado e piso térreo e três andares de altura», acrescentando ainda outra característica das torres de menagem românicas, que nos parece explicar a posição desta torre interior do castelo de Outeiro: «Dentro de um conceito de defesa passiva, a torre de menagem românica foi entendida como um verdadeiro "castelo dentro do castelo", último reduto de defesa, e que por isso devia estar isolada das restantes estruturas, no centro do pátio, detendo os restantes dispositivos do castelo.» 330

Embora não seja uma característica apenas dos castelos românicos, não podemos deixar de assinalar a existência da cisterna, junto à torre interior, por isso nesta metade norte do castelo. Voltando a citar Mário Jorge Barroca: «Desde meados do século XI, quando começam a triunfar as grandes operações de cerco, dá-se especial atenção ao aprovisionamento de água. Os pátios começam a ter poços ou cisternas.» ${ }^{331}$

Por último, uma referência à "porta falsa» ou da traição, própria dos castelos românicos e que no caso de Outeiro terá sido reformulada com uma barbacã rasgada com troneiras (Planta 6).

Resumindo esta análise aos debuxos de Duarte de Armas, consideramos que o castelo de Outeiro apresenta vários momentos de construção, onde se poderão destacar duas fases principais: a primeira que aparentemente nos remete para uma possível construção românica, e por isso anterior a D. Dinis, e cujos vestígios são mais evidentes na metade norte da fortaleza. E outra, cujas estruturas se localizam na parte sul do castelo, obedecendo a uma filosofia gótica, e que poderão ter começado a ser erguidas ainda durante o reinado de D. Dinis, traduzindo-se na construção ou adaptação da entrada sudoeste, com o antemuro e os balcões com matacães, e talvez na construção da torre de menagem e do torreão coberto. Depois de D. Dinis, terá sido construída a cerca da vida, após 1355, e que nos desenhos do escudeiro aparece sem construções e, finalmente, já durante o século XV, talvez durante as reformas de D. João II ou D. Manuel, poderá ter sido construída a barbacã com as troneiras cruzetadas.

\footnotetext{
330 BARATA, TEIXEIRA, dir., 2003: 112.

${ }^{331}$ BARATA, TEIXEIRA, dir., 2003: 112.
} 


\subsubsection{A função residencial do castelo de Outeiro}

Por volta dos séculos XIV e XV, muitos castelos portugueses, onde se contam alguns exemplos na região transmontana, adotaram características residenciais. Segundo João Gouveia Monteiro, terá sido durante este período que os castelos deixaram de ser um sítio exclusivo para «abrigo de forças militares» adotando, em linha com as suas congéneres europeias ${ }^{332}$, uma função mais civil que conferisse conforto ao alcaide e à sua guarnição, que passam a ser obrigados a permanecer mais tempo na fortificação. Esta transformação residencial dos castelos terá acontecido primeiramente na reforma das torres de menagem, onde se abriram vãos mais amplos para iluminar e arejar os pisos superiores ${ }^{333}$, estendendo-se depois à construção de novas estruturas dentro da praça.

Por outro lado, e ainda segundo João Gouveia Monteiro, o reino português não terá ficado alheio ao facto de em Castela, e durante o século XIV, algumas fortalezas terem ganhado um cunho «senhorial», marcando domínios familiares e imprimindo aos castelos uma função defensiva e doméstico-residencial ${ }^{334}$. Nesta linha de pensamento, não nos podemos esquecer que grande parte dos castelos e povoações de Trás-os-Montes passariam para os domínios da Casa de Bragança, criada em 1442, com a doação feita pela Coroa a D. Afonso, $10^{\circ}$ duque de Bragança ${ }^{335}$. É provável que tenha sido durante a jurisdição destes senhores, que os castelos transmontanos tenham beneficiado de melhorias, nomeadamente ao nível residencial, proporcionando a estadia das suas famílias e subordinados, nas visitas que fariam pelas suas terras.

Longe dos castelos-palácios de Castela e Leão, da segunda metade do século $\mathrm{XIV}^{336}$, o castelo de Outeiro beneficiou destas transformações residenciais, bem patentes nos elementos que já anteriormente mencionamos, nomeadamente na existência de chaminés, de um número considerável de janelas e divisões adossadas aos panos de muralhas, certamente com pisos sobradados e com funções residenciais. Para além destes espaços, há ainda as torres, que para além da sua função primordial militar, também poderiam ter divisões destinadas a armazenamento ou habitação. Finalmente o balcão de higiene, construído sobre a muralha do lado noroeste (Planta 7).

Embora não possamos adiantar muito mais sobre a função residencial do castelo de Outeiro sabemos, pela documentação, que em $1530^{337} \mathrm{o}$ alcaide vivia na fortaleza e que em $1758^{338}$ ainda se conservavam as casas onde moravam os militares e o governador.

\footnotetext{
332 MONTEIRO, 1999: 45.

333 BARROCA, 1990-1991: 125

${ }^{334}$ MONTEIRO, 1999: 45. O autor ao expor esta ideia cita NAVAREÑO MATEOS, 1988: 128.

${ }^{335}$ COSTA, 1868: 495-497; MENDONÇA, 1995: 242-243; FREITAS, 2009: 130.

${ }^{336}$ COBOS GUERRA, CASTRO FERNÁNDEZ, 1998: 212-215.

${ }^{337}$ FREIRE, 1909: 265.

338 CAPELA et al., 2007: 294-297.
} 


\subsection{ABORDAGEM ÀS PLANTAS DO CASTELO DE OUTEIRO PRODUZIDAS DURANTE O SÉCULO XVIII}

Depois da análise dos desenhos de Duarte de Armas, fixemo-nos agora nas plantas que sabemos terem sido executadas durante o século XVIII, apresentando todas elas características muito semelhantes, com exceção de uma ${ }^{339}$, que não se igualando às restantes, sabemos, pela legenda apresentada, que foi desenhada depois das destruições das tropas castelhanas em 1762 (Plantas 8 à 13).

O conjunto das seis plantas que representam o castelo de Outeiro e a cerca da vila no século XVIII, encontram-se no Gabinete de Estudos Arqueológicos da Engenharia Militar-Direção de Infraestruturas do Exército. A Planta 13, datada de 1762, foi também publicada no trabalho de Carmen Manso Porto ${ }^{340}$.

A análise dos principais elementos e a sua posterior comparação permitiram estabelecer uma proposta evolutiva do castelo ao longo do período que medeia os anos de 1509 e 1762, isto é, entre os desenhos de Duarte de Armas e a planta de Carmen Manso Porto, salientando-se o que perdurou e o que foi transformado na fortificação. Esta comparação assentou sobretudo na observação da planta de 1762, pois todas as outras, excetuando alguns pormenores irrelevantes, apresentam o mesmo desenho.

Numa primeira análise podemos dizer que todas as plantas representam o castelo com os mesmos elementos, mantendo-se, grosso modo, as mesmas estruturas dos desenhos de Duarte de Armas, onde se veem as duas torres, uma delas a de menagem, a enquadrar uma das portas, as barbacãs e a cerca da vila.

Notamos ainda que, nas Plantas 8 e 12, são representadas, dentro do perímetro da cerca da vila, duas construções, correspondendo uma delas à capela de Santa Luzia, referida nas Memórias Paroquiais de $1758^{341}$, e a outra a um poço ou cisterna.

A Planta 10, difere das restantes por ser muito esquemática, dando a entender que o seu propósito foi indicar, através de um esboço, o que foi destruído pelos castelhanos. Aliás esta indicação está explícita na legenda, onde podemos ler que «As muralhas q'são cobertas de riscos negros forão destruídas $\mathrm{p}^{\text {los }}$ Castelhanos». Outro pormenor interessante é que esta planta tem uma legenda com a indicação: «A Porta do castelo»; «B Capela»; «C Quartos»; «F Plataforma» e «G Aroquela». A letra «G» que tem como indicação: «Aroquela» está desenhada no pátio do castelo. Assim, ficamos esclarecidos que, para além da capela, a cerca da vila tinha também quartos, talvez destinados às tropas. As destruições dos castelhanos,

\footnotetext{
${ }^{339}$ A Planta 10 que tem como legenda «Planta do castelo [de] Outeiro: feito por ordem do Illm. ${ }^{\circ}$ e Exm. ${ }^{\circ}$ S.or Gorge Cary, Tenente General dos Exercittos de S. Mag.de Fidell.ma».

${ }^{340}$ MANSO PORTO, 1999: 57-58.

${ }^{341} \mathrm{Na}$ campanha de escavações arqueológicas de 2019, no âmbito da Operação Castelos a Norte, promovida pela Direção Regional de Cultura do Norte, foram encontrados vestígios de um templo que poderá corresponder a esta capela. Os resultados desta campanha ainda não são públicos.
} 
assinaladas com uma trama preta, estendem-se à quase totalidade cerca da vila; a parte da capela e dos «quartos»; e aos muros oeste e leste do castelo, parecendo manter-se apenas a zona da porta da entrada e a curva da muralha voltada a norte. Curiosamente o desenho apresenta o que parece ser uma segunda linha que não sabemos se corresponderá a outro muro, ao limite de uma plataforma ou a um erro. Por fim, apenas uma nota para a representação a norte do que julgamos ser a ribeira da Vila.

A planta da qual temos mais informações é a que foi publicada por Carmen Manso Porto, com a data de 1762 . No seu trabalho a autora escreve que

El castillo de la villa de Outeiro fue ocupado el 13 de mayo de 1762 por el teniente general marqués de Ceballos, que partió con su destacamento ese mismo día desde Alcañices. Se hallaba abandonado y se quemaron las puertas y todas las maderas que había en su interior. De todo ello nos informa una carta de D. Antonio Barba a su tío fray Agustín de Salamanca, capuchino de Madrid. El castillo de la villa de Outeiro había sido mandado construir por el rey Dinis (1261-1325). En el plano que conservamos faltan la toponimia y las claves para identificar sus estancias ${ }^{342}$.

Encontrando o castelo abandonado, os castelhanos queimaram todas as portas e madeiras do interior, tendo apenas ficado as paredes da fortaleza. Da observação da planta podemos verificar que as torres representadas são as mesmas que Duarte de Armas desenhou por volta de 1509, bem como, grande parte da muralha do castelo que se estende para norte (Planta 14).

As entradas continuam a ser duas, com as suas barbacãs. Nestes últimos elementos parece ter havido alterações. O antemuro de Duarte de Armas aparece na planta de 1762 fechado contra a cerca da vila e com porta voltada a sul. A barbacã da entrada voltada ao interior da cerca parece ter sido reformulada, tendo-se construído muros esquadriados e desaparecido o torreão coberto de Duarte de Armas (Planta 15).

As divisões das construções interiores da praça do século XVIII mantêm, no essencial, a disposição desenhada por Duarte de Armas, com exceção para duas construções a norte. Poderá não ser uma alteração, mas talvez um erro de perspetiva do escudeiro, que prolonga as construções quase até ao topo norte do pátio. Na planta de 1762, as construções são representadas de forma mais geométrica, diferindo apenas um pouco nas habitações do lado norte da torre interior (Planta 16).

\footnotetext{
${ }^{342}$ MANSO PORTO, 1999: XXXVII.
} 
Ainda sobre o castelo, e um pormenor que achamos interessante, é o troço do muro que liga as duas torres nas suas faces norte (menagem) e sul (torre interior). No desenho de Duarte de Armas, este muro é desenhado com uma curvatura pronunciada, partindo do canto noroeste da torre de menagem e fechando junto à porta, que se abre para sul, da torre interior. Neste desenho do século XVI, a espessura do muro não difere dos restantes. No desenho do século XVIII, o mesmo muro, com uma curvatura menos pronunciada, apresenta a espessura de uma muralha, com uma porta voltada a sul.

Deixamos ainda um apontamento para o traçado da cerca da vila que Duarte de Armas não representou na sua planta. Nos seus desenhos, o escudeiro faz com que a cerca encoste a sul, no canto sudeste da torre de menagem, já no desenho de 1762, a cerca parte do canto sudoeste. Na vista E-NE do escudeiro a cerca tem um traçado, mais ou menos ovalado podendo, no entanto, verificar-se alguns ângulos, e abrem-se duas portas, uma a sul e outra a norte. Na planta de 1762, a cerca tem muros retilíneos, com ângulos pouco pronunciados, à exceção da zona sul, onde o muro curva para fechar na torre de menagem. Nesta última planta a cerca apresenta uma única porta a norte (Planta 17).

Finalmente, um apontamento para um pormenor da planta do século XVIII. Os muros da cerca da vida, da muralha, das barbacãs e das torres, são desenhados com três linhas, formando duas espessuras diferentes. Do lado de fora dos muros, foi representada uma faixa estreita que julgamos poder tratar-se de um parapeito, que na época de Duarte de Armas teria algumas ameias.

Resumindo a nossa análise, podemos concluir que o castelo de Outeiro não terá sofrido grandes alterações entre o século XVI e XVIII, mantendo o essencial da sua planta e da sua estrutura militar. Muitas das diferenças podem não corresponder a obras ou alterações na estrutura do castelo, mas antes a diferenças de perspetiva dos desenhadores, como a espessura dos muros ou a disposição das construções dentro do pátio.

Na planta de 1762, o corpo de edifícios que encosta à muralha voltada a oeste, isto é, à aldeia, parece ter portas no primeiro andar que dariam acesso ao adarve. De facto, se observarmos a vista oeste de Duarte de Armas, vemos pelo menos duas aberturas com arco de volta perfeita nesta zona, que poderão corresponder às mesmas portas. Aliás, na sua planta, o escudeiro não representa aberturas nesta parede, significando que elas não foram abertas no pano da muralha, mas na parede do primeiro andar do paço.

Reparamos também que na planta de 1762 não são representados os balcões com matacães nem as troneiras cruzetadas. Esta ausência não quer dizer que elas não existissem, mas pode simplesmente significar que o desenhador não achou per- 
tinente representá-las, podendo encontrar-se entaipadas, ou poderá tê-las referido numa descrição ou legenda, que Carmen Manso Porto diz faltar no anexo à planta.

Finalmente, não podemos deixar de sublinhar a afirmação que Carmen Manso Porto nos deixa no seu trabalho: «El castillo de la villa de Outeiro había sido mandado construir por el rey Dinis (1261-1325).» ${ }^{343}$ Ficamos, contudo, sem perceber em que se baseou a autora para fazer esta afirmação.

\subsection{OS VESTÍGIOS QUE CHEGARAM ATÉ NÓS}

Depois de termos analisado as plantas que desenharam uma parte da «vida» do castelo de Outeiro, voltamo-nos agora para aquilo que são os seus vestígios, pois a partir da destruição dos castelhanos, em 1762, a fortaleza entrou num acelerado processo de abandono e degradação.

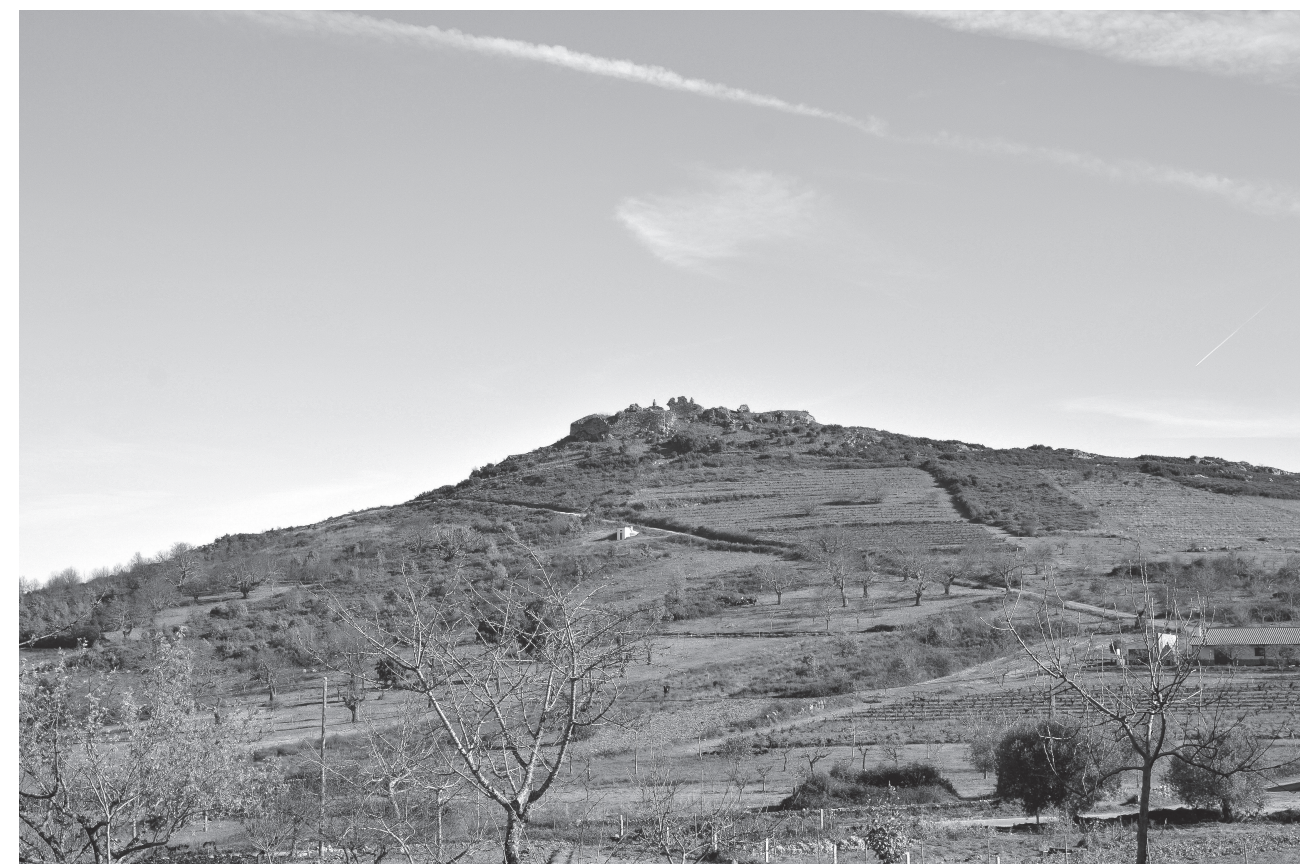

Fig. 6. Ruínas do castelo de Outeiro vistas da povoação

Em pouco mais de dois séculos, o castelo de Outeiro ficou reduzido a ruínas, mantendo a custo algumas partes da muralha, que ainda hoje se encontram erguidas, sobretudo a oeste e a leste.

${ }^{343}$ MANSO PORTO, 1999: XXXVII. 


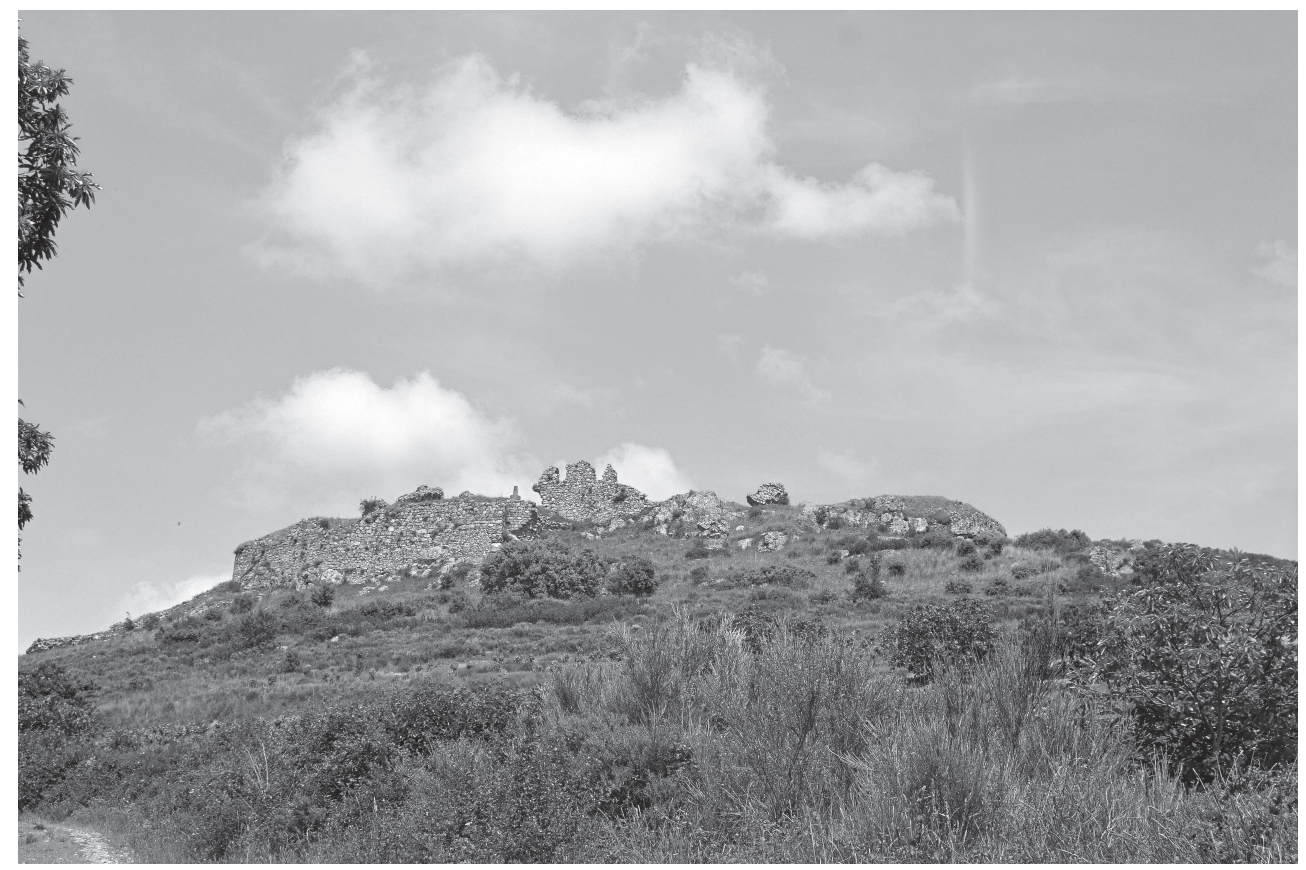

Fig. 7. Vista oeste das ruínas do castelo de Outeiro

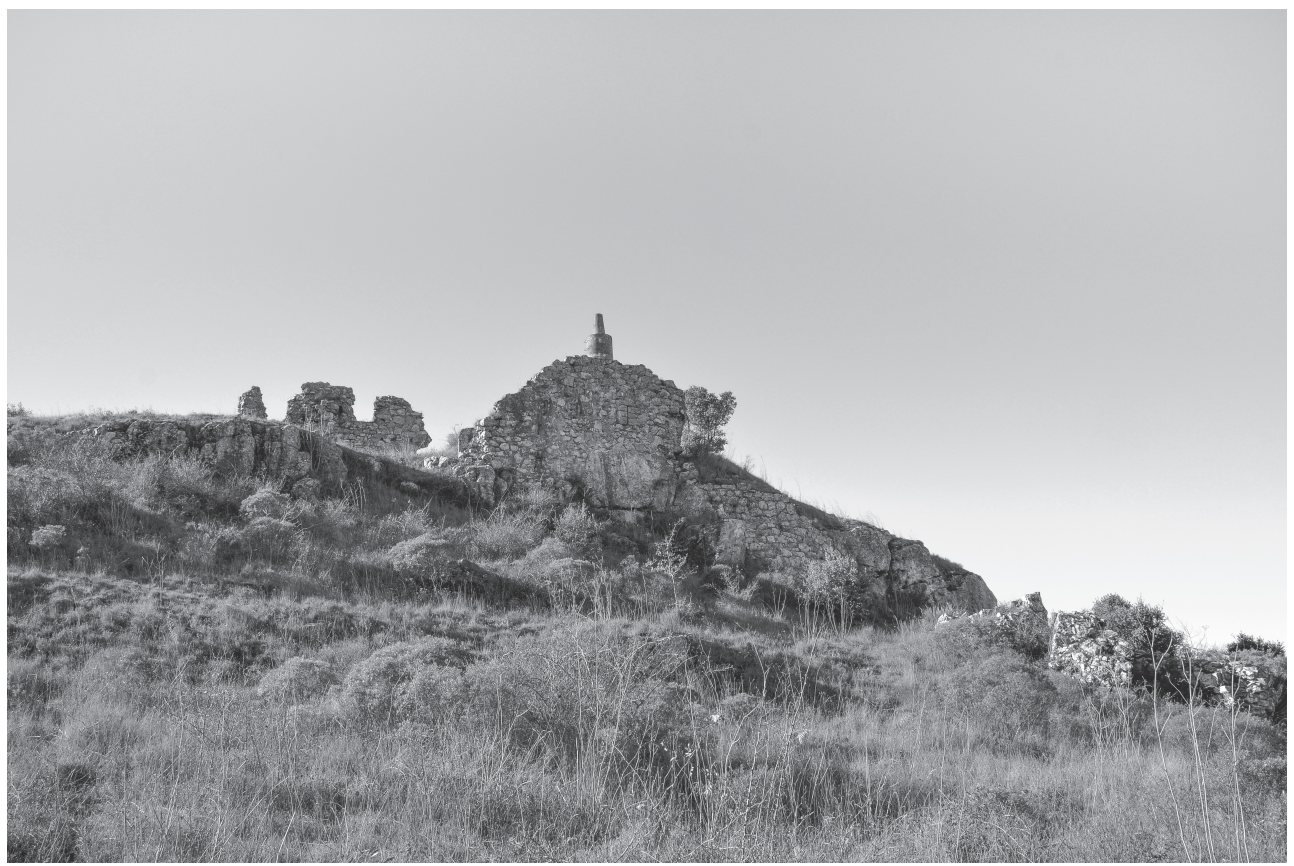

Fig. 8. Vista leste do castelo de Outeiro 


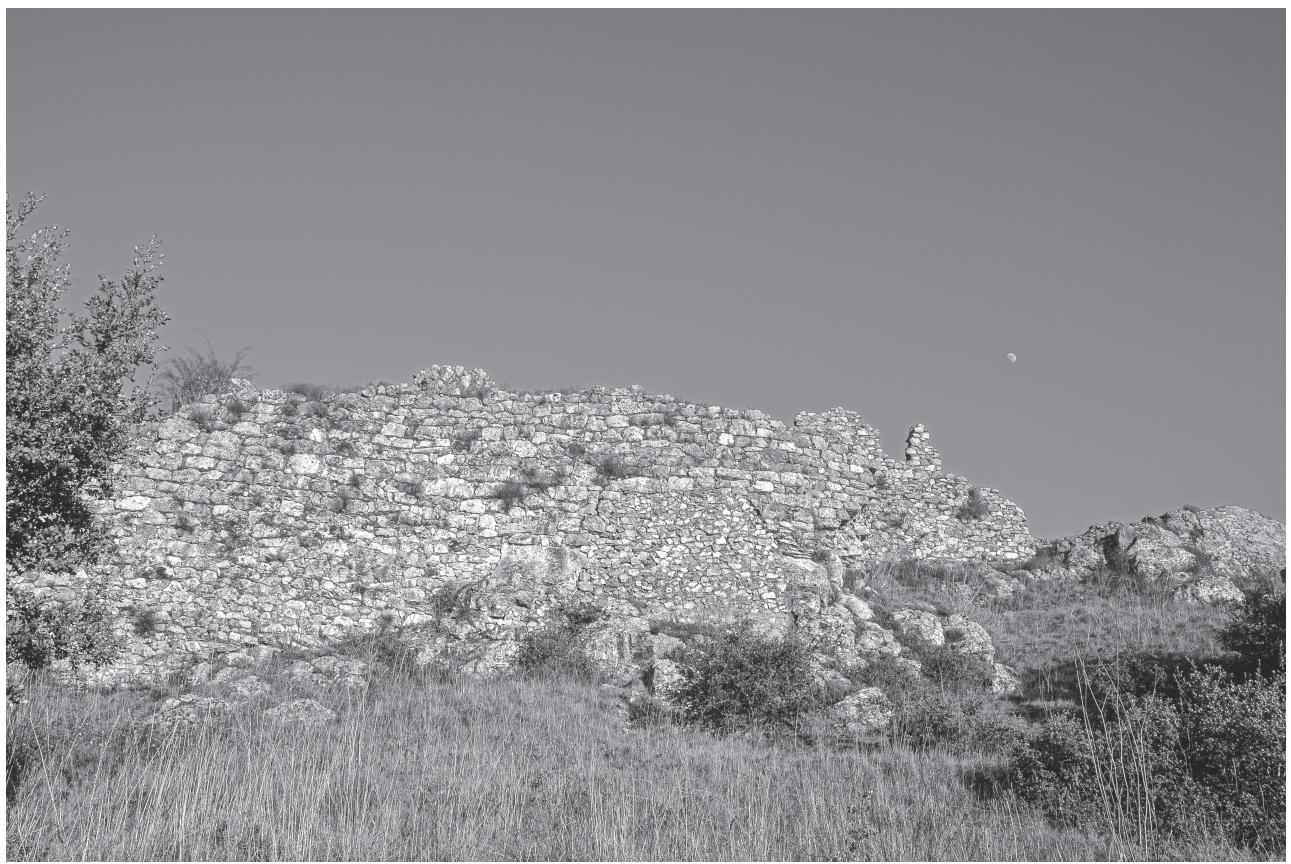

Fig. 9. Obras de restauro onde são visíveis os «remendos» na parte inferior da muralha

Ausente dos planos de restauro dos monumentos nacionais que foram considerados emblemáticos pelo Estado Novo, o castelo de Outeiro apresentava, na segunda metade do século $\mathrm{XX}$, rombos significativos no que restava dos seus muros. Destas destruições dão-nos conta Francisco Felgueiras ou Pedro Verdelho, em fotografias que ilustram os seus trabalhos ${ }^{344}$. Em 1993, as entidades responsáveis pelos monumentos históricos efetuaram trabalhos de consolidação dos muros, preenchendo os rombos que punham em perigo o que restava da muralha do castelo. Estes restauros são visíveis nos panos da muralha, não só pelas diferenças de aparelho, mas também pelos materiais usados, como o cimento. Terá sido nesta altura que se desenhou a última planta do castelo de Outeiro e que consta da base de dados do SIPA ${ }^{345}$. Este desenho, muito rudimentar, mostra alguns troços de muros assinalados a cinzento, podendo corresponder a zonas intervencionadas pelos restauros, não acrescentando informações significativas à compreensão do castelo.

Outra fonte de observação e auxílio foram as imagens de satélite do Google Earth $^{346}$, que permitiram, não só uma leitura espacial do território ao redor do cas-

\footnotetext{
${ }^{344}$ Ver fotos em FELGUEIRAS, 1968: 11-12 e VERDELHO, 2000: 74.

${ }^{345}$ Sistema de Informação para o Património Arquitetónico (SIPA): http://www.monumentos.pt.

${ }^{346}$ Google Earth. Image, 2015 DigitalGlobe.
} 
telo, como também, identificar o traçado da cerca da vila e da muralha do castelo. $\mathrm{Na}$ imagem podemos distinguir na zona norte alguns troços de muralha ainda erguidos. Embora já muito destruída, a cerca da vila aparece bem delineada, ocupando a plataforma voltada à fronteira.

A reunião de todos estes elementos foi primordial para a nossa observação de campo. Este trabalho teve como base a planta desenhada em 1762, por ser a mais completa, e a planta de Duarte de Armas, que serviu para confrontar/confirmar estruturas, medidas e identificar elementos que foram essenciais na formulação das nossas dúvidas e hipóteses.

Apesar da densa vegetação que cobria todo o outeiro onde se ergueu o castelo, pudemos confirmar uma parte significativa da estrutura desenhada em 1762 e que corresponde, grosso modo, à fortaleza representada por Duarte de Armas (Planta 18).

Esta observação superficial, dificultada pelas condições do terreno, permitiu identificar a quase totalidade da torre de menagem, um pequeno troço do que julgamos ser a torre interior, quase todo o perímetro da muralha do castelo e o que nos parece uma parte da barbacã voltada à cerca. Embora bastante destruída, e muito encoberta pela vegetação, confirmamos todo o perímetro da chamada "cerca da vila», incluindo a porta de entrada voltada a norte.

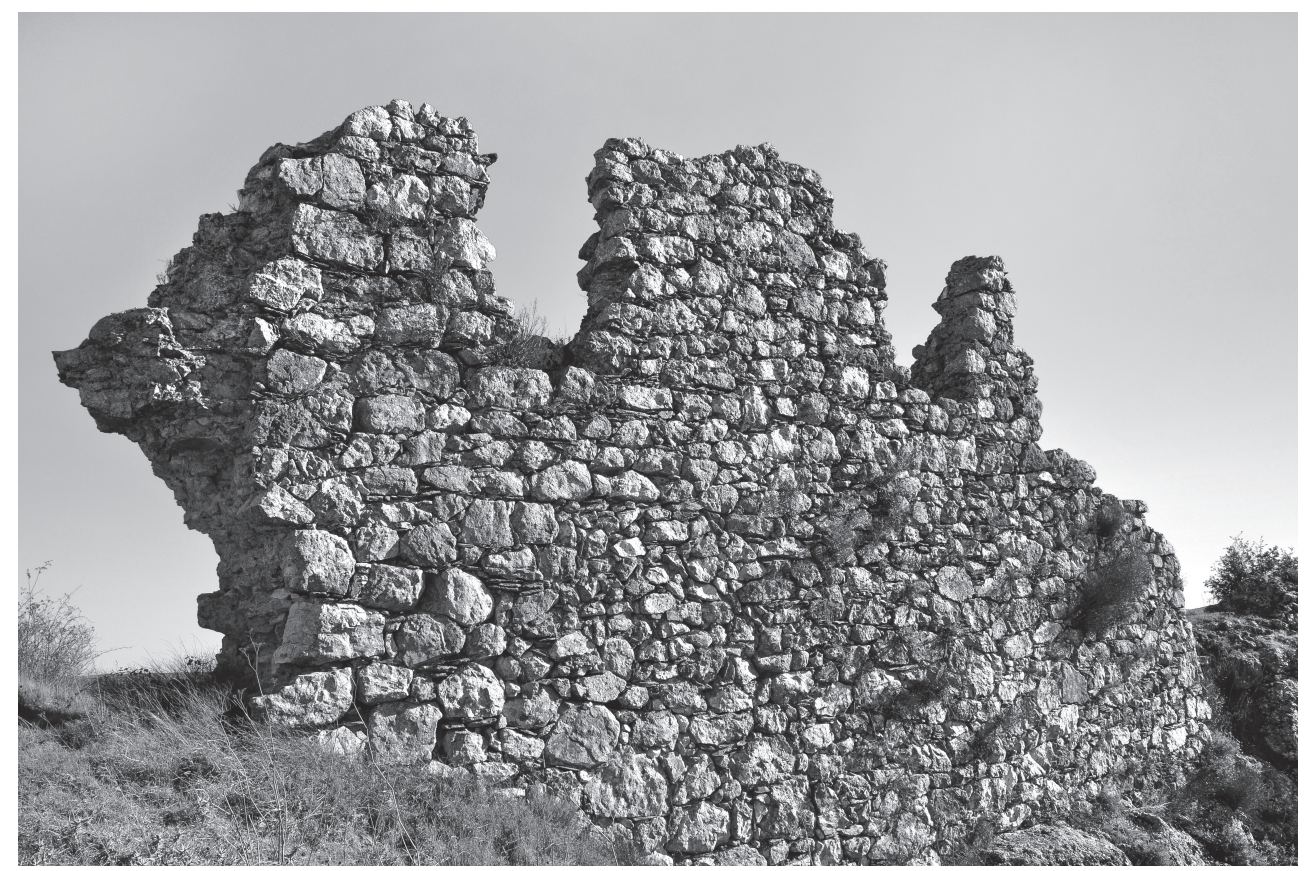

Fig. 10. Alçado da muralha voltada a oeste 
Para além do esboço da planta, tivemos ainda a oportunidade de fazer algumas medições ${ }^{347}$ que nos permitiram acrescentar alguns dados aos já conhecidos.

Duarte de Armas diz-nos que a fortaleza tem 95,26 m de muralha, isto sem contar com a torre de menagem. Segundo o que pudemos observar em campo, e excetuando a área da torre de menagem e das barbacãs, o pátio mediria cerca de $51 \times 20 \mathrm{~m}$, totalizando uma área de aproximadamente $1020 \mathrm{~m}^{2}$. Relativamente à espessura das muralhas do castelo verificamos que mediam apenas $1,50 \mathrm{~m}$. O escudeiro de D. Manuel I diz-nos que mediriam 2,20 m.

Hoje apenas existem dois tramos de muros, acima da cota do solo: um voltado a leste, com 9,50 m de comprimento, e outro que corresponderia ao troço de muralha que ligaria as duas torres, com 12,70 m. A restante muralha está toda derrubada até à cota atual do interior da praça.

A torre de menagem, medida pelas extremidades interiores, tem cerca de 5,60x3,60 m, totalizando pouco mais de $20 \mathrm{~m}^{2}$ de área útil. No seu desenho, Duarte de Armas indica as medidas desta torre com 5,50x3,8 m, sendo a diferença de apenas alguns centímetros. A espessura dos seus muros parece ter sido de cerca de 1,35 m.

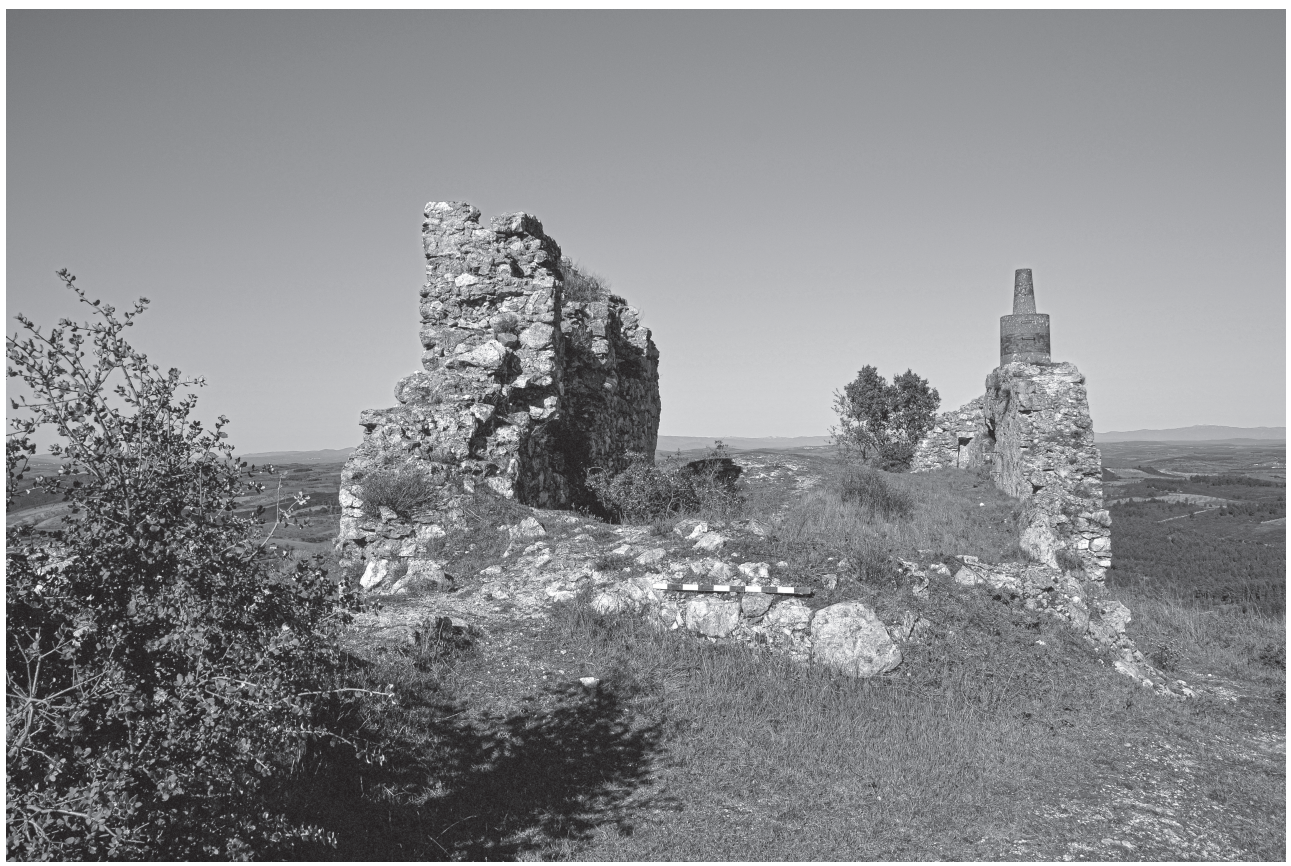

Fig. 11. Zona onde se erguia a torre de menagem e se conservam alguns arranques de muros

\footnotetext{
${ }^{347}$ As medições de campo foram tiradas com fita métrica e por isso devem ser lidas como aproximadas, podendo
} mostrar erros nas distâncias maiores. 


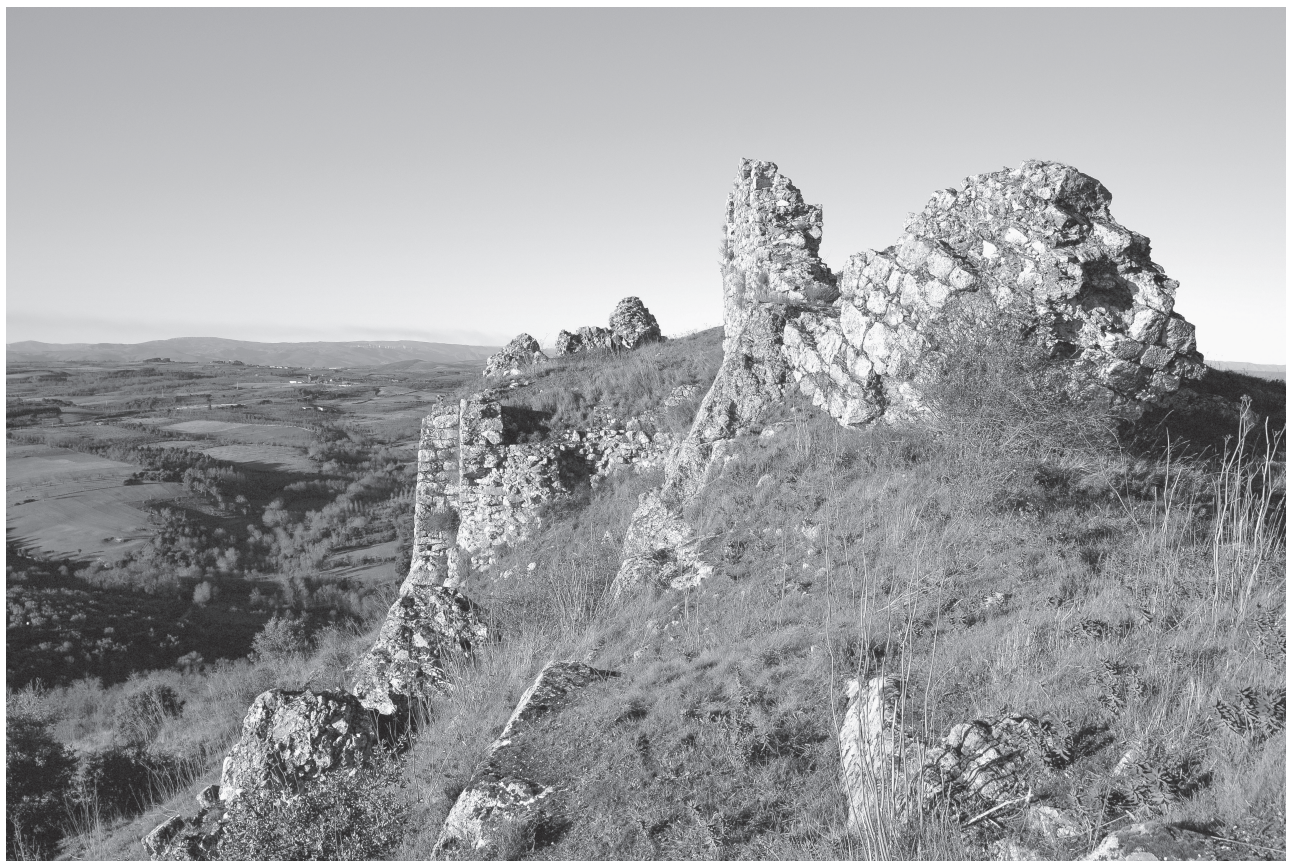

Fig. 12. Pormenor da entrada sudoeste, onde arrancava o antemuro

Aparentemente a torre encostava à muralha, pelo lado exterior, pois nesta zona a espessura do muro é de cerca de $3 \mathrm{~m}$. Já para a torre interior não foi possível tirar qualquer medida, pois os vestígios são diminutos.

As estruturas com vestígios menos evidentes a olho desarmado são as barbacãs. Da que ficava a proteger a porta sudoeste não identificamos qualquer vestígio, exceto um orifício circular num dos penedos que poderia ter servido de gonzo da porta de entrada nesta estrutura, contudo temos muitas dúvidas acerca da sua verdadeira funcionalidade. Da barbacã que protegia a entrada voltada à cerca da vila, identificamos um troço de muro, com cerca de $11 \mathrm{~m}$ de comprido, que assinalamos na nossa planta. Contudo, dadas as condições do terreno, não nos foi possível confirmar a sua verdadeira função.

Finalmente a cerca da vila desenha-se na sua totalidade. Esta estrutura é bem visível na zona sul, onde faz uma curva e encosta à muralha do castelo. Em campo, e apesar da vegetação, é visível a zona da porta norte da cerca. No interior do recinto há muita pedra solta e blocos da muralha. Contudo, não identificamos qualquer alinhamento de construções. $O$ formato da cerca também não foi confirmado, trabalho apenas possível com levantamento topográfico.

Deixando por ora a planta, fixemos a nossa atenção em alguns vestígios que nos auxiliaram na leitura das diferentes fases construtivas do castelo. 


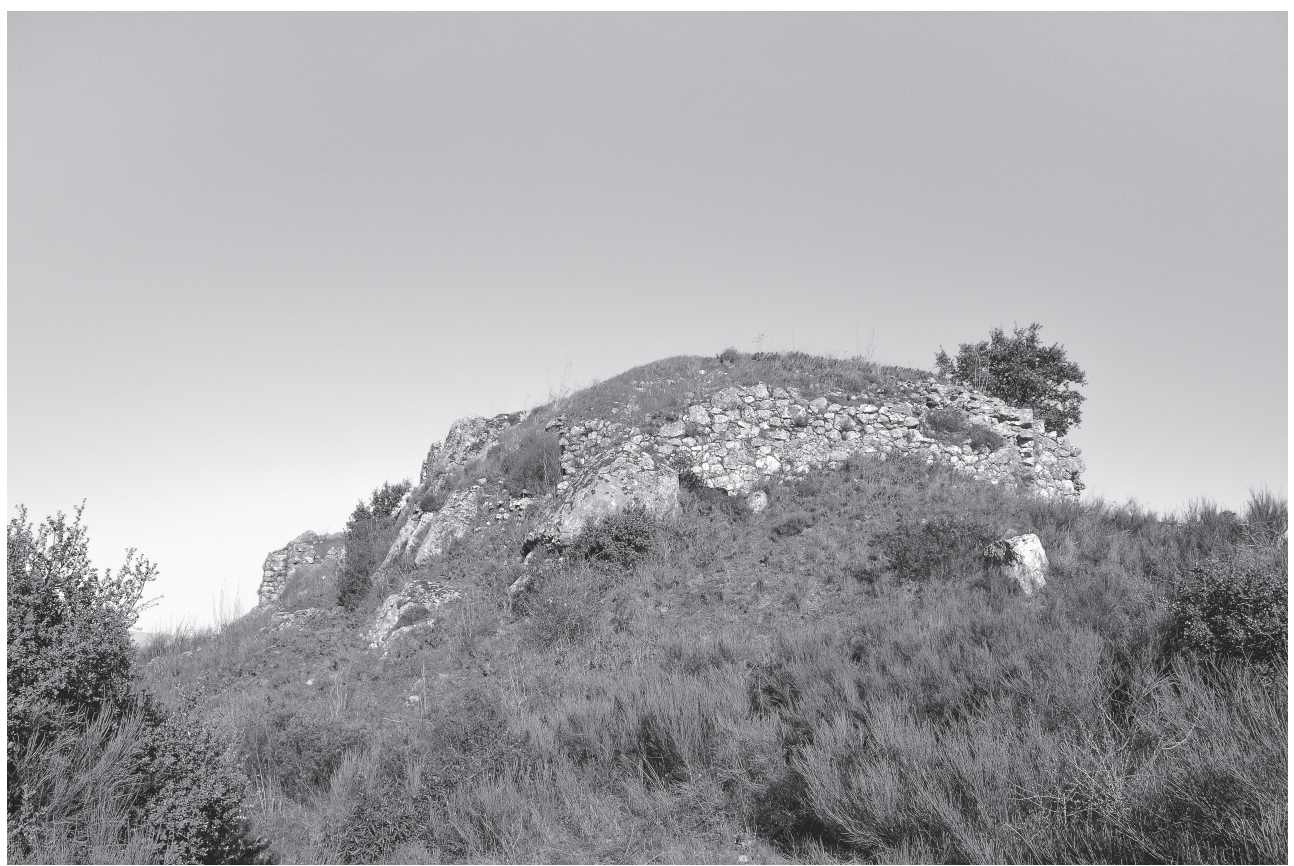

Fig. 13. Zona sul da cerca da vila

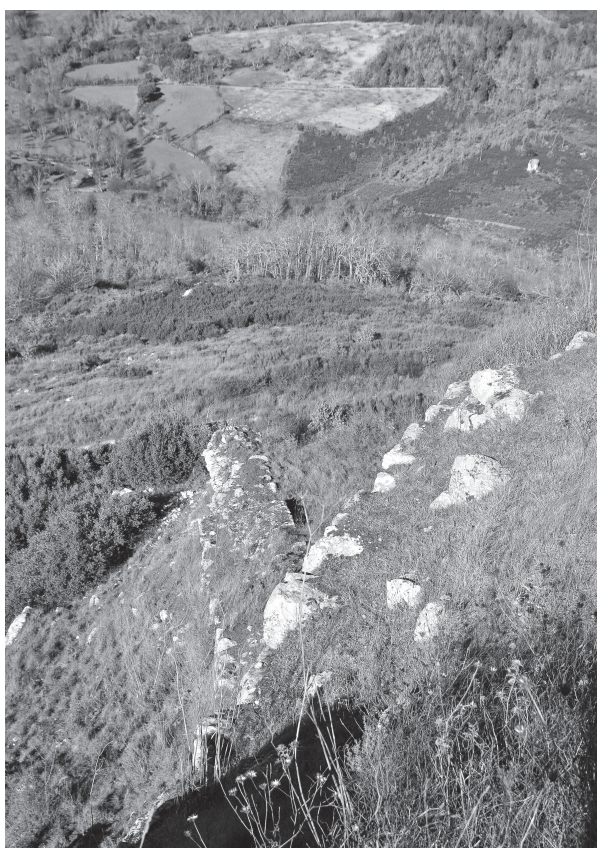

Fig. 14. Zona norte onde a cerca da vila encosta à muralha do castelo

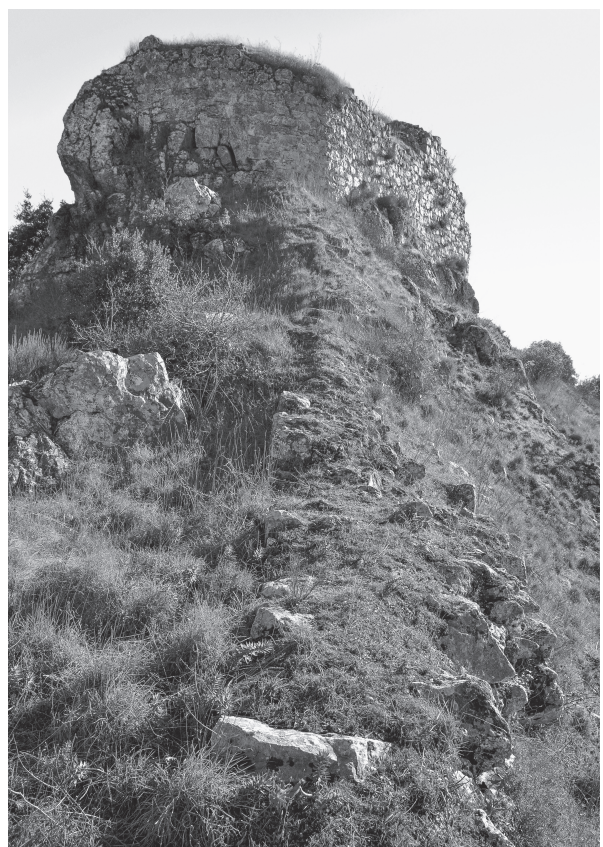

Fig. 15. Troço norte das ruínas da cerca da vila 


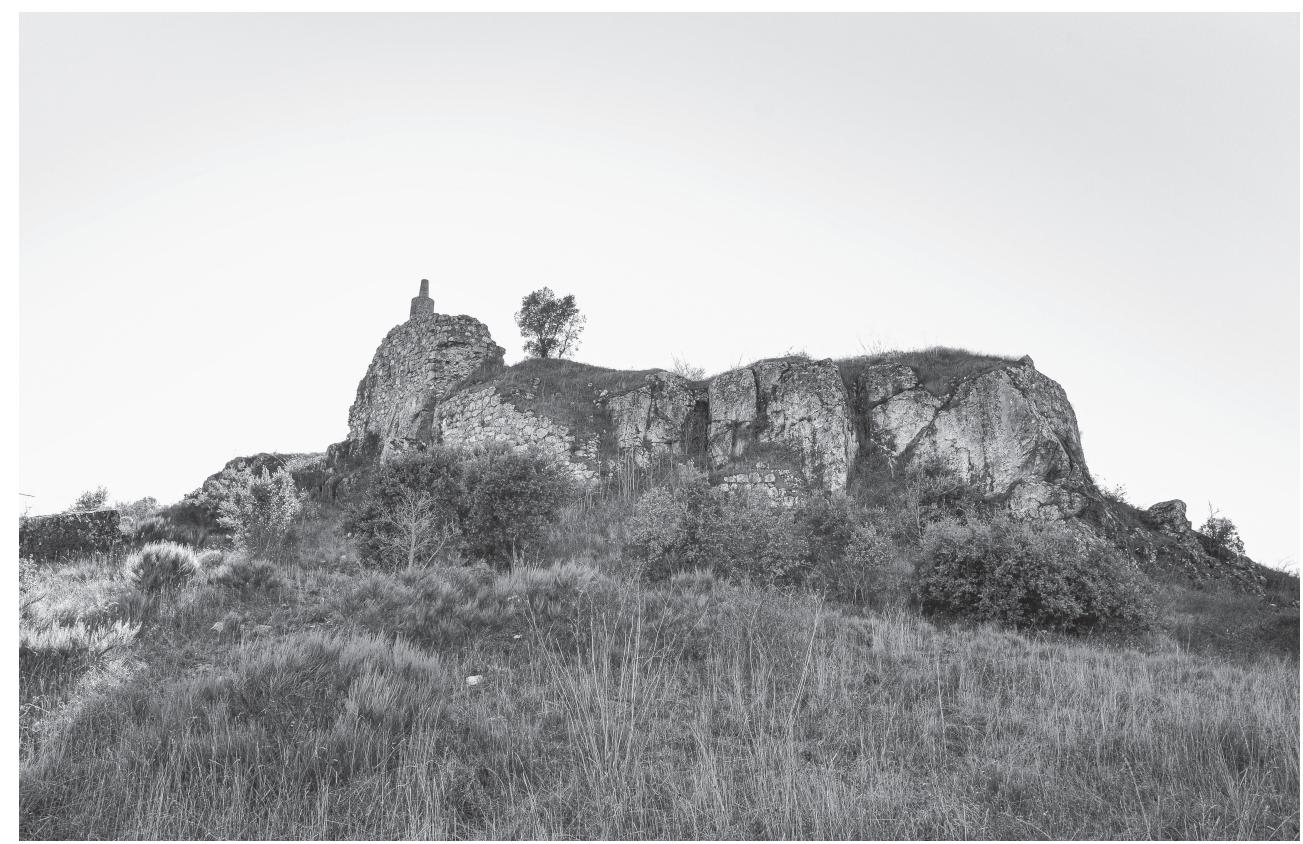

Fig. 16. Penedos verticalizados para a construção da muralha. Zona leste

A primeira observação vai para os alçados das muralhas. Como já referimos, os muros do castelo assentam em penedos, que em certos locais, como a leste e nordeste, parecem ter sido verticalizados para encostar ou assentar a muralha. Na zona norte e oeste, a muralha adapta-se à irregularidade dos penedos.

A muralha foi construída em alvenaria, com pequenos blocos graníticos ou rochas metamórficas, tendencialmente retangulares, e argamassas amareladas. As pedras foram assentes em fiadas horizontais, cuja regularidade era mantida com blocos de diferentes tamanhos e formato, sendo visíveis lascas de xisto que ajudavam a horizontalizar as fiadas ou a verticalizar os blocos. O interior do muro era preenchido com cascalheira e argamassa, como podemos ver na zona junto à entrada sudoeste. Este tipo de construção parece homogéneo desde a zona da referida entrada, contornando a penedia a norte, até à zona voltada a leste, onde se eleva o pano de muralha acima da cota do solo. Este troço do muro, onde foi implantado o marco geodésico, parece ter sofrido restauros, sendo difícil avaliar se o seu sistema construtivo corresponde, ou não, à muralha que acabamos de descrever. Contudo é possível que parte da construção corresponda ao mesmo tipo.

Já o muro que ligaria as duas torres, do qual ainda se conserva uma parte do alçado, parece ter um aparelho ligeiramente diferente, apresentando blocos mais pequenos, menos regulares e com fiadas pouco horizontais, apesar das muitas placas de xisto usadas entre as pedras. 


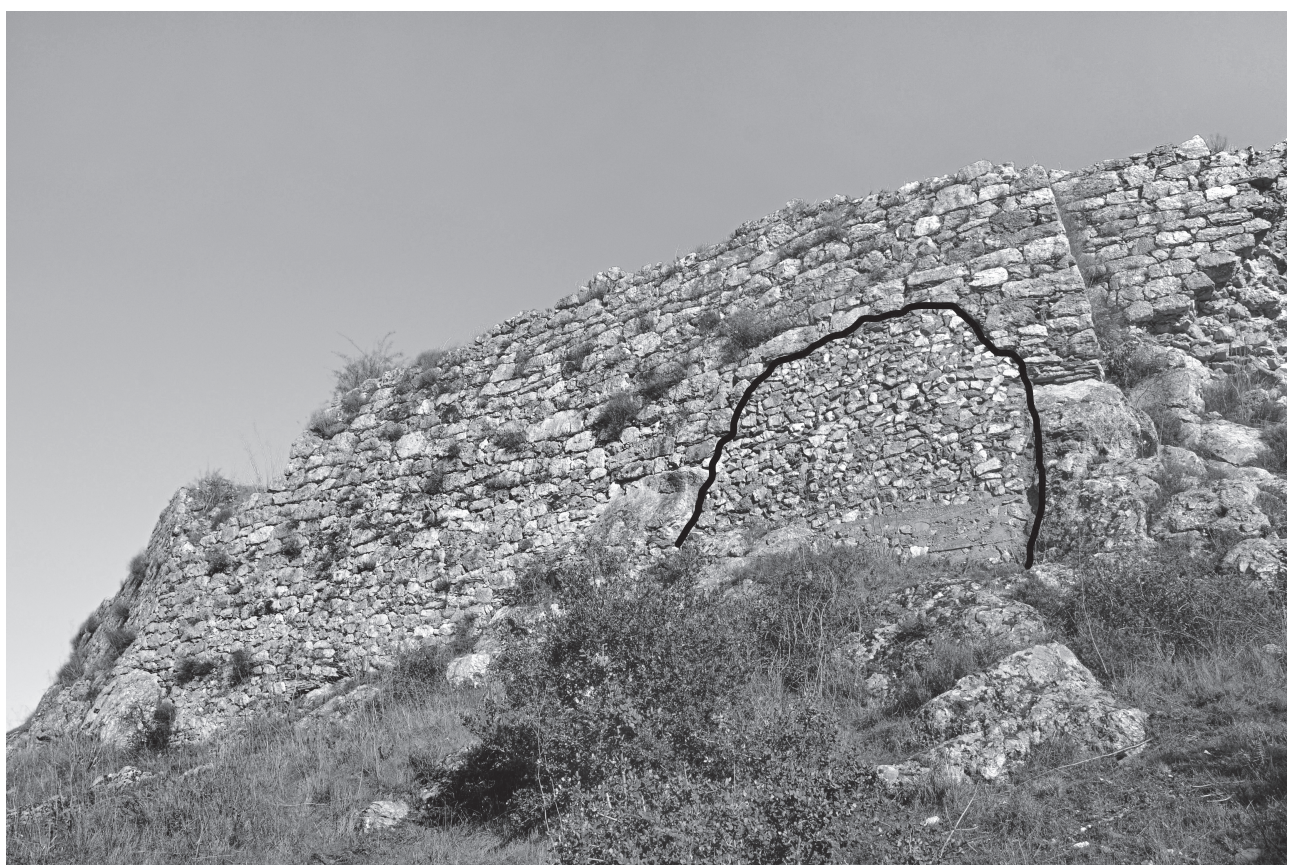

Fig. 17. Aparelho mais antigo da muralha, com as reconstruções do século XX. Alçado voltado a oeste

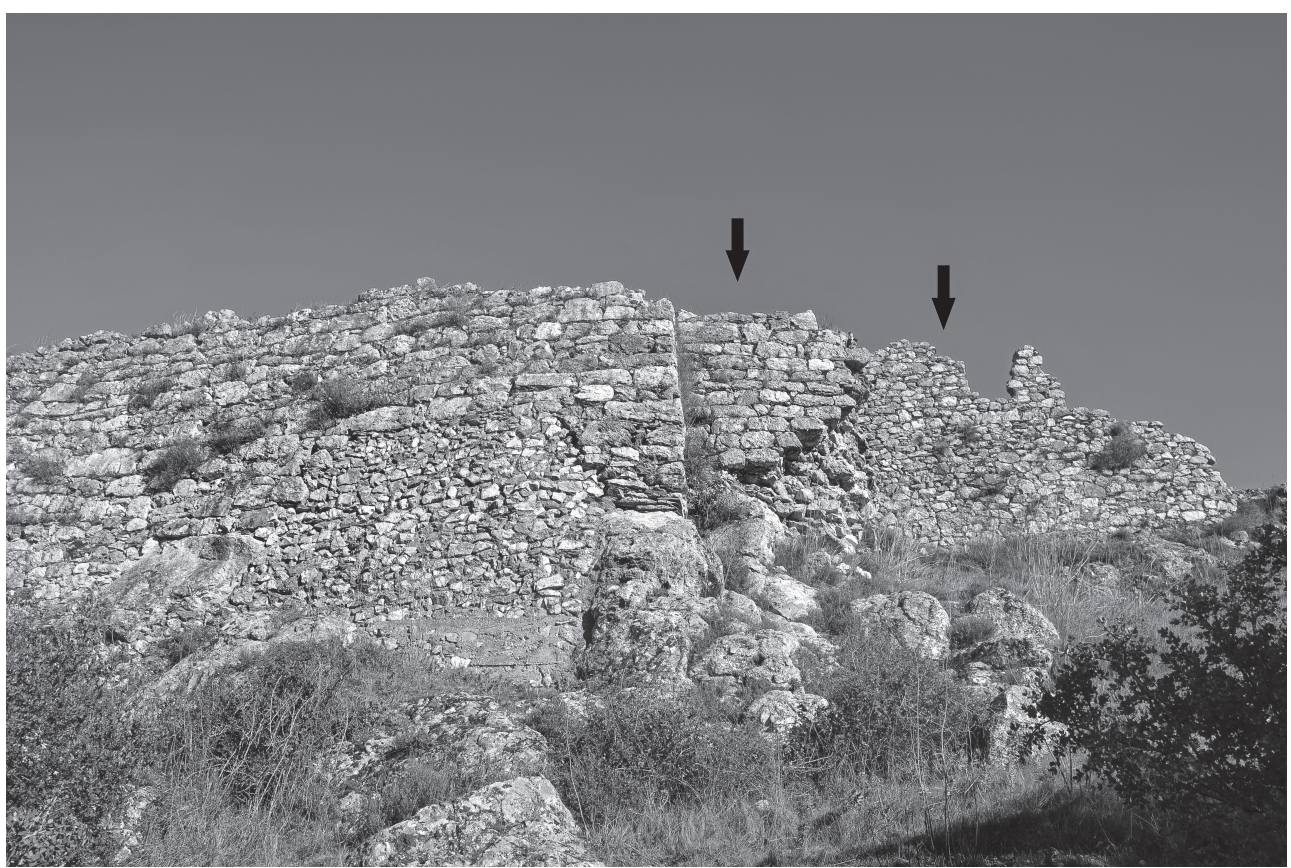

Fig. 18. Comparação entre os dois aparelhos dos alçados oeste 


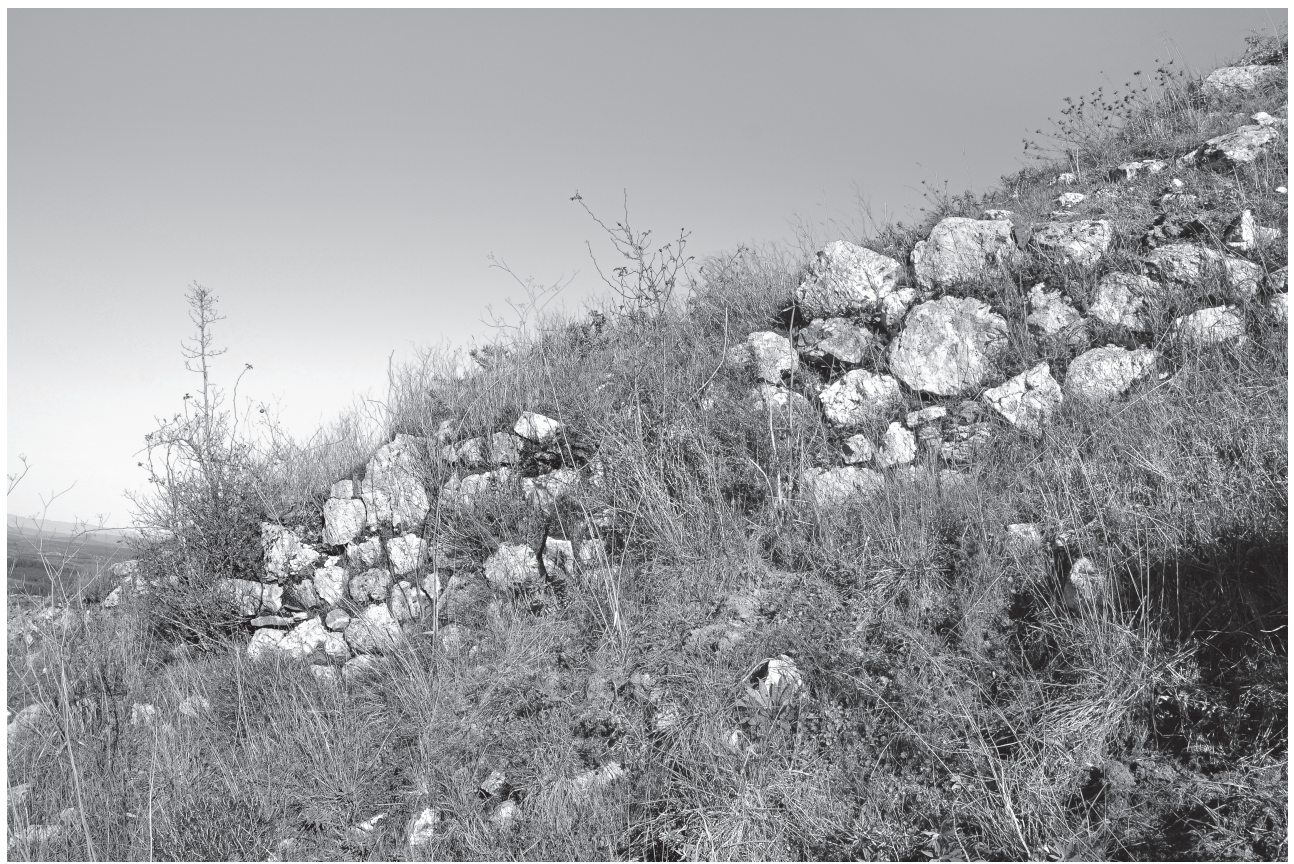

Fig. 19. Pormenor do aparelho construtivo da cerca da vila. Zona norte

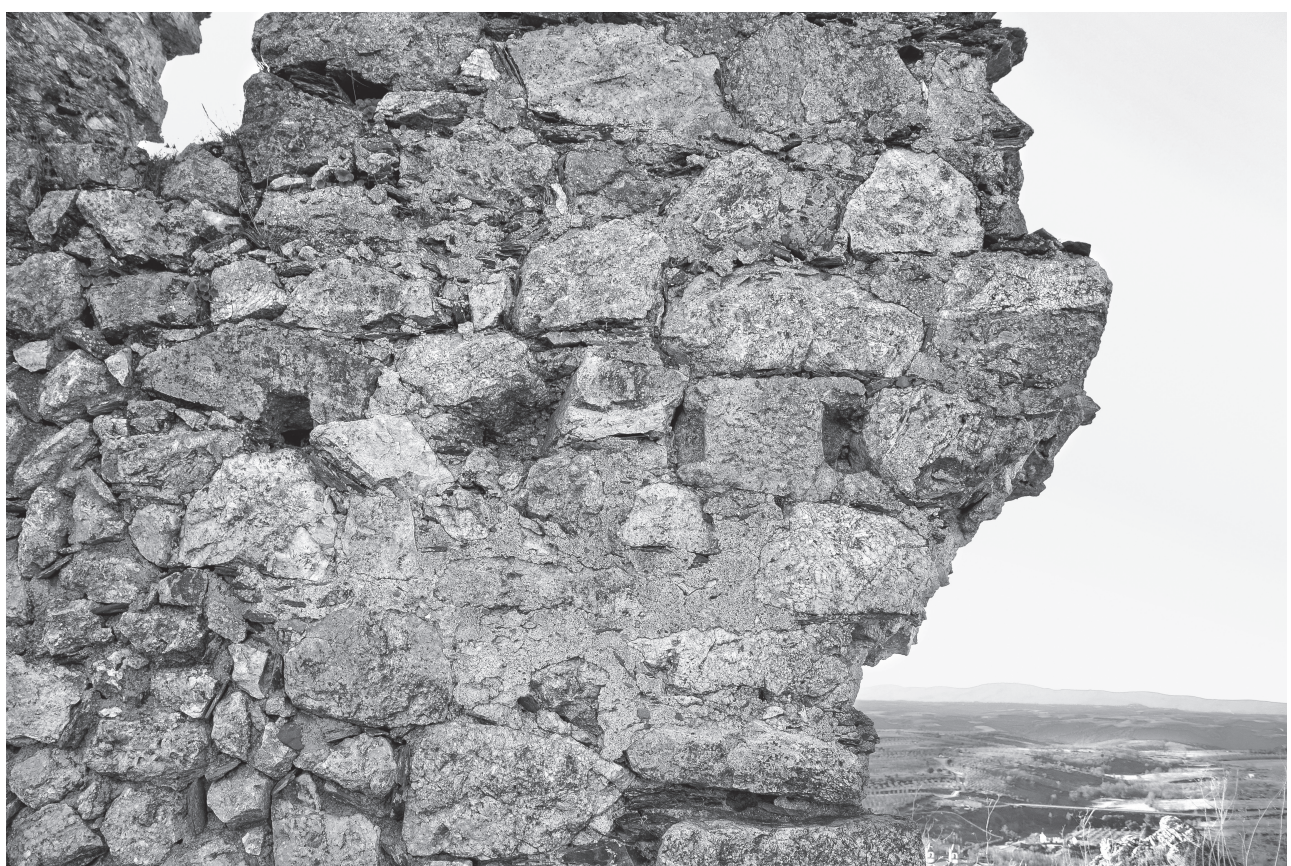

Fig. 20. Encaixes para construção do piso sobradado 


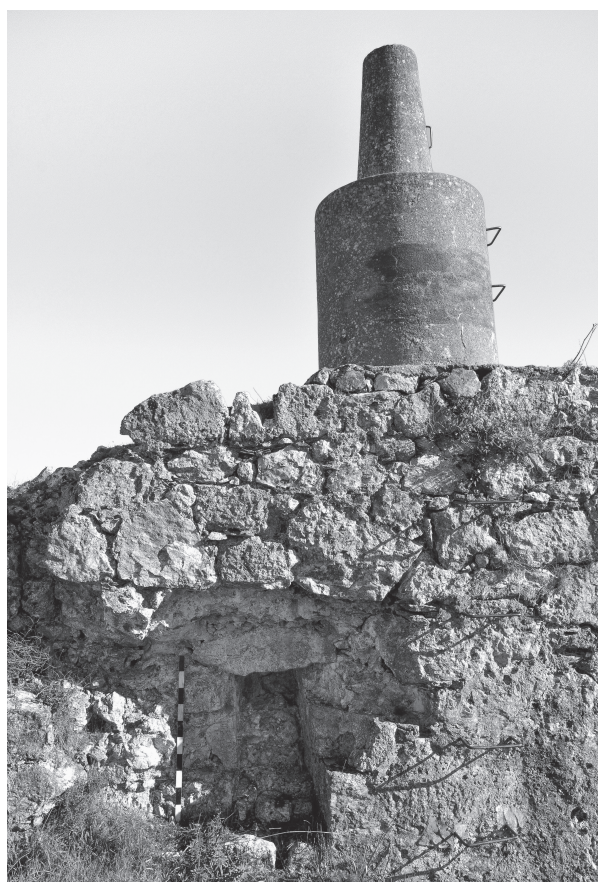

Fig. 21. Pormenor interior da seteira voltada a leste

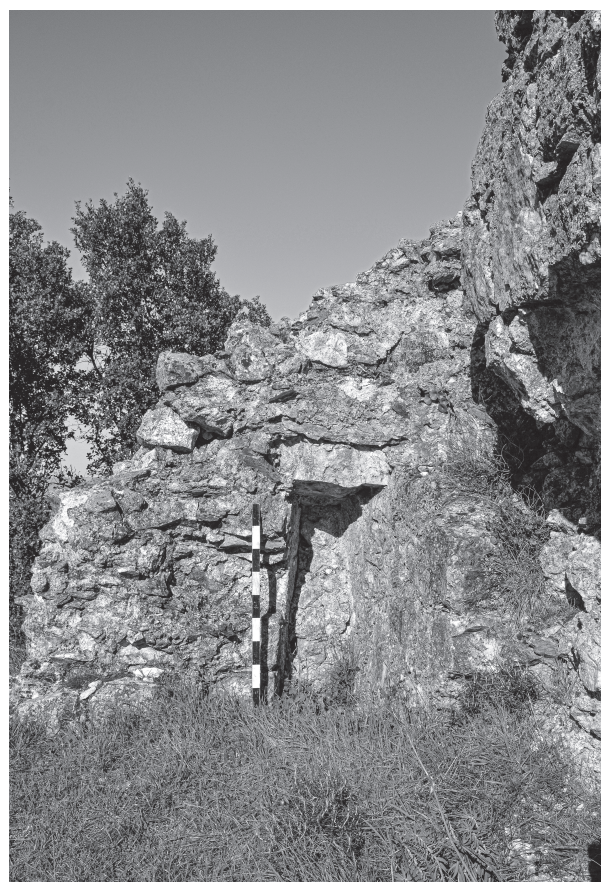

Fig. 22. Pormenor interior da seteira norte

O muro da cerca da vila é também ele construído em alvenaria, sem, contudo, haver intenção de formar fiadas horizontais, ou que os blocos tenham uma forma homogénea. Nota-se de facto, que se trata de uma construção diferente da muralha.

Para além da técnica construtiva das muralhas, realçamos ainda dois pormenores que observamos nos alçados que ainda se conservam. O primeiro pormenor vê-se no alçado interior do muro que ligaria as duas torres. Apesar da destruição e dos restauros, são ainda visíveis alguns negativos para o encaixe das traves do sobrado.

A segunda observação, e mais importante, foi feita no troço de muralha voltado a leste, onde identificamos duas seteiras que foram entaipadas e inutilizadas.

Apesar da destruição do muro, e mais uma vez das argamassas de cimento, estes elementos são bem visíveis, tanto do lado interior como exterior da muralha. Foram rasgadas num pequeno cotovelo da muralha, uma voltada a leste e outra a norte. Este ângulo na muralha, não se encontra representado nas plantas do século XVIII, mas aparece na planta de Duarte de Armas, ficando em frente à entrada voltada para a cerca da vila. O escudeiro não faz qualquer representação destes elementos na planta, mas na vista E-NE vê-se, como já referimos, uma janela gradeada voltada a leste, próxima de uma das seteiras. Do lado exterior da muralha, são bem visíveis estes mecanismos de tiro, construídos com blocos graníticos talhados. 


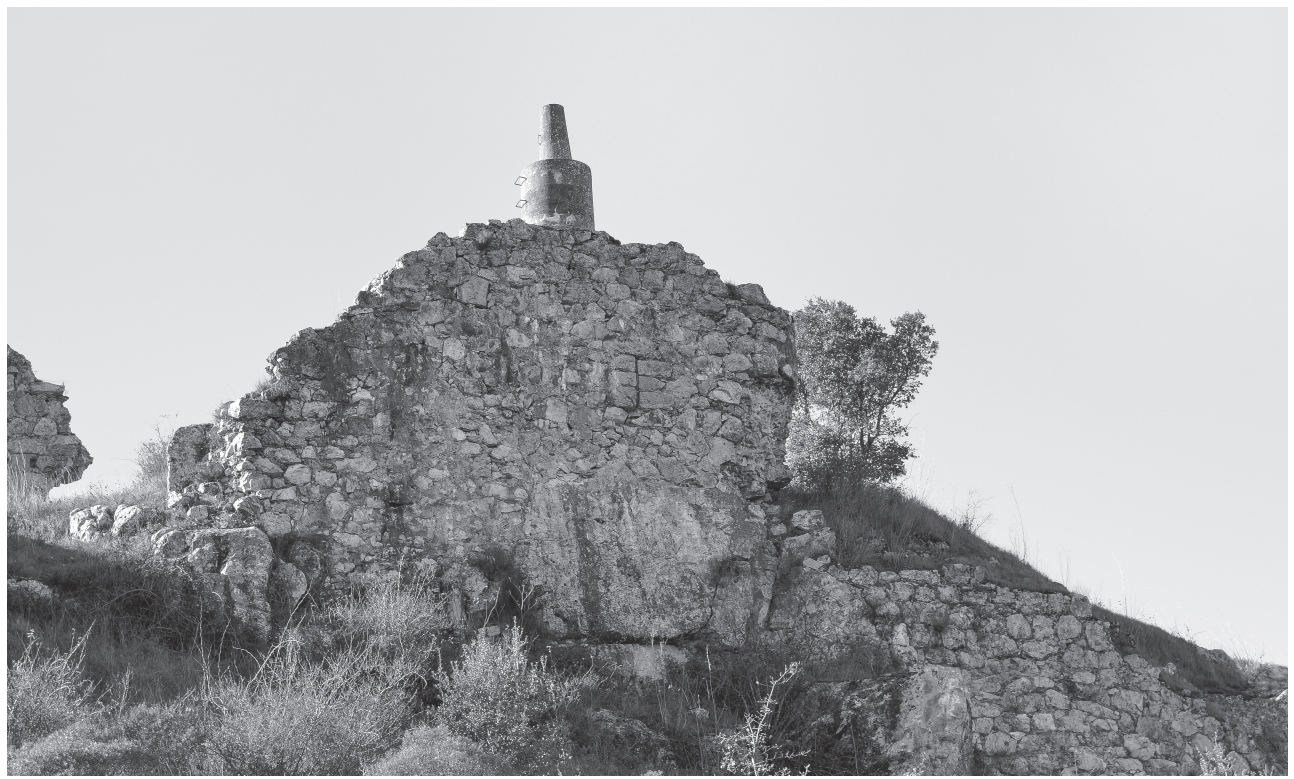

Fig. 23. Seteira voltada a leste

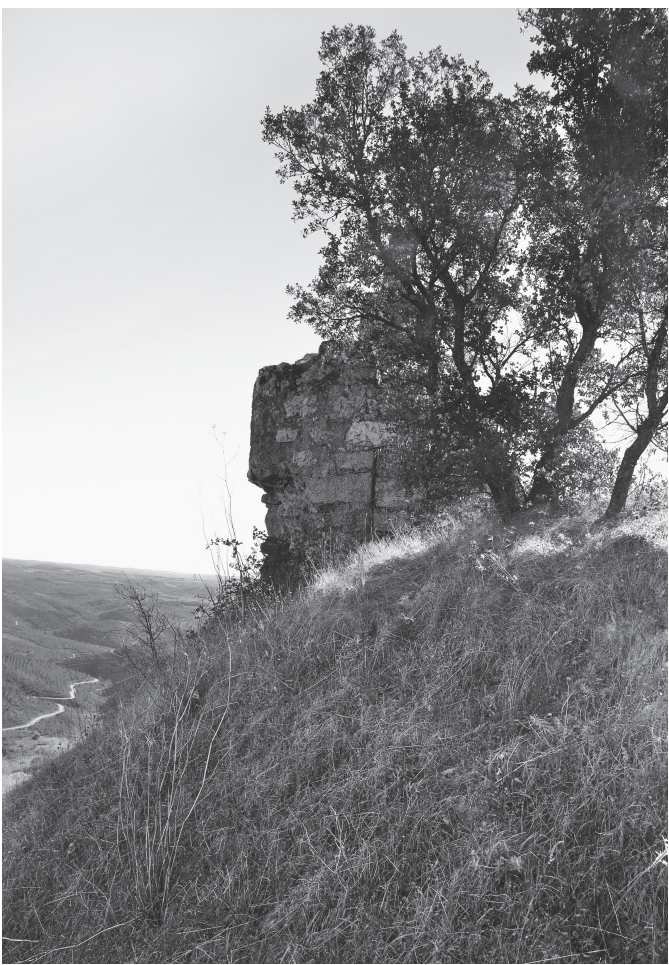

Fig. 24. Seteira voltada a norte
Deixamos ainda uma nota para os aterros e desaterros existentes na zona da fortificação. Julgamos que alguns destes aterros serão consequência da destruição dos muros. Daí não ter sido possível observar a cisterna, que Duarte de Armas aponta nos seus desenhos, sendo provável que se encontre soterrada. Não apuramos se este aterro foi fruto do abandono do castelo, ou se foi intencional, de forma a substituir a cisterna pelo poço que ficava no interior da cerca, ganhando assim espaço na praça. Já na zona sul da cerca da vila, no local onde o muro curva para leste, parecem ter sido feitos aterros para a regularização do terreno, talvez ainda durante a construção da estrutura. Por último, na zona da entrada sudoeste, onde hoje 
existe um grande desnível e onde outrora teria que haver uma plataforma de acesso à porta do castelo, parece ter havido grandes desaterros. Esta plataforma seria contida pelo antemuro que Duarte de Armas representa e que mais tarde foi fechado. Com a destruição do muro esta plataforma terá desaparecido, existindo agora um desnível.

Finalmente, e para além das estruturas, deixamos aqui uma observação sobre os vestígios arqueológicos de superfície como as cerâmicas e outros materiais. Apesar da vegetação cobrir quase todo o outeiro, dificultando a observação do solo, veem-se algumas cerâmicas espalhadas pela plataforma, sobretudo materiais de construção e alguma cerâmica comum, cujas cronologias são difíceis de precisar, sendo certo que há materiais modernos e contemporâneos. Na zona da cerca, e como já referimos anteriormente, há alguma concentração de pedra solta e blocos da própria fortaleza, que rolaram pelo outeiro. Nos taludes do estradão que dá acesso ao castelo, principalmente na zona oeste, voltada à aldeia, vê-se alguma cerâmica de construção e comum.

\subsection{FASES CONSTRUTIVAS DO CASTELO DE OUTEIRO}

Concluída a análise dos debuxos de Duarte de Armas, desenhados a partir de 1509, das plantas produzidas no século XVIII e do exame dos vestígios observados em campo, estamos em condições de apontar algumas observações e questões que consideramos pertinentes para a compreensão do castelo de Outeiro.

O nosso estudo permite-nos reforçar a ideia de que o castelo de Outeiro não obedeceu a um plano único de construção e não teve apenas uma fase de edificação. Na verdade, a observação dos desenhos de Duarte de Armas, sugere-nos, logo à partida, uma planta onde se identificam dois importantes momentos de construção, que refletem diferentes opções construtivas. A zona norte do castelo, onde se integra a torre interior, parece corresponder a uma estrutura com características românicas, por seu turno a zona sul, parece ter sido erguida segundo o conceito de defesa ativa, característica própria das fortalezas góticas.

Embora não tenhamos confirmado na documentação a existência de um castelo antes de $1361^{348}$, parece-nos que tanto as plantas como os vestígios de campo apontam para uma construção anterior a esta data. Esta hipótese é lançada por alguns autores, como já mencionamos, sem nunca fundamentarem as suas afirmações. Ora, a observação dos elementos anteriormente referidos, levam-nos a sugerir que a construção do castelo de Outeiro possa realmente ser anterior ao reinado de D. Dinis.

A nossa hipótese é sustentada, antes de mais, pela análise dos debuxos de Duarte de Armas, cujos elementos nos remetem para a planta da muralha; para a

\footnotetext{
${ }^{348}$ Data em que o castelo é referido pela primeira vez nos documentos consultados. Chancelarias Portuguesas: D. Pedro I (1357-1367), 1984: 268.
} 
torre interior, que pensamos se ergueria isolada no meio do pátio; para a existência de uma cisterna ao lado da torre; e para a uma porta falsa, junto à entrada sudeste. Para além destes elementos, observamos ainda as diferenças no aparelho construtivo e as duas seteiras que se abrem para leste e norte.

Por fim, não podemos deixar de mencionar a afirmação que Carmen Manso Porto faz no seu estudo, a propósito da planta do castelo de Outeiro, desenhada em 1762. A autora escreve que o castelo terá sido construído por D. Dinis, não sugerindo nenhum ano ou momento do seu reinado. Contudo, ele pode ter sido construído antes d'O Lavrador ter assumido o reino. Note-se que as Inquirições de 1258 não fazem referência à fortaleza e que a aldeia de Outeiro pertencia ao mosteiro de Castro de Avelãs. Mas, sabemos que durante o reinado de D. Dinis, a povoação estava dividida em dois núcleos, sendo possível que o outeiro do castelo pertencesse aos termos de Miranda. Daí não ser estranha a possibilidade de aqui já existir uma construção militar, talvez erguida por iniciativa régia. Porém mantém-se a dúvida sobre a data da primeira construção, e se ela se enquadra no "período românico» ou no «período gótico» das construções militares. Segundo Mário Jorge Barroca: «Em Portugal, apesar dos primeiros sintomas remontarem ao reinado de D. Sancho I, as reformas góticas só viriam a triunfar muito mais tarde, despois de 1250, com mais de meio século de atraso.» ${ }^{349}$ Assim sendo, e se considerarmos a construção norte do castelo de Outeiro uma edificação românica, esta teria que ser anterior a 1250 .

Já as construções da zona sul do castelo de Outeiro, não parecem levantar dúvidas quanto à sua natureza gótica. Aqui as dúvidas colocam-se nos diferentes momentos de construção e nos períodos em que ocorreram. Será provável que as entradas do castelo tenham recebido as primeiras reformas, com a construção do torreão coberto a defender a entrada voltada à cerca e o antemuro na outra entrada. Na mesma fase ou em época posterior terão sido construídos a torre de menagem, encostada à muralha, e do lado exterior; o muro que liga as duas torres, e que permite a defesa da entrada sudoeste; e os balcões de tiro vertical. Todos estes elementos poderão ter sido construídos entre os reinados de D. Dinis e D. João I. Contudo, sabemos pela documentação ${ }^{350}$ que, a partir de 1414, e durante o reinado do Mestre de Avis, se terá concluído a cerca da vila. A construção dos edifícios dos paços para alojamento do alcaide e possivelmente da guarnição, poderá ter ocorrido, como já referimos, entre a segunda metade do século XIV e XV. Já a introdução das troneiras cruzetas, e talvez da barbacã voltada à cerca da vila, poderão ter sido construídas a partir da segunda metade do século $\mathrm{XV}^{351}$.

\footnotetext{
${ }^{349}$ BARROCA, 2003a: 171.

${ }^{350}$ Chancelarias Portuguesas: D. João I (1410-1418), 2006: vol. III, tomo 3, 173.

${ }^{351}$ MONTEIRO, 1999: 40-41.
} 
Relativamente à cerca da vila, não sabemos se no seu interior foram construídas casas para os moradores de Outeiro, tal como era vontade da população em 1355 e de D. João I, em $1414^{352}$. A documentação apenas dá conta do despovoamento da vila em $1418^{353}$, sendo possível que a ocupação da cerca não tenha tido sucesso. Contudo, as plantas do século XVIII mostram representações de casas para militares, uma capela e um poço. Não temos dados suficientes para apontar uma cronologia para estas estruturas, porém podem terem sido erguidas já em época moderna/contemporânea.

$\mathrm{Na}$ falta de elementos mais concretos, deixamos alguns exemplos de fortificações que chegaram até nós e que apresentam soluções idênticas às do castelo de Outeiro, levando-nos a reafirmar a hipótese de ter existido um castelo anterior a D. Dinis.

O primeiro exemplo é o castelo de Freixo de Espada à Cinta que faz parte da primeira linha de defesa da fronteira transmontana. Esta fortaleza parece ser das mais antigas desta região, podendo ter sido construída após D. Afonso Henriques ter dado foral à localidade ${ }^{354}$. Em 1258, há notícias de obras na fortaleza, motivo pelo qual se supõe que existiria um reduto defensivo, talvez constituído por uma cerca, que defendesse a povoação ${ }^{355}$. Desta construção primitiva não há notícias, contudo Rita Costa Gomes põe a hipótese de a torre de menagem do castelo ter sido, primeiramente, uma das torres quadrangulares que, entretanto, foi demolida e que teria uma «traça mais arcaica» ${ }^{356}$.

Atravessando o rio Douro e já na região da Beira Alta temos outros exemplos que podemos apontar de castelos com duas torres, cuja construção pode corresponder a períodos do início da nacionalidade. É o caso do castelo de Pinhel que se integra na rede de castelos que protegia a fronteira quando esta se desenhava pelo Coa. A localidade terá recebido foral de D. Sancho I em 1189, data a partir da qual se terá construído o castelo. Esta fortificação terá sofrido obras posteriores, sendo alargada durante o reinado de D. Dinis. «De facto, entre o último quartel do século XII e o primeiro quartel do século XIII, seis torres de planta quadrada são construídas.» ${ }^{357}$ Hoje ainda subsistem duas torres, ambas isoladas no meio do recinto fortificado. Uma delas tem janela manuelina e balcões com matacães. A outra torre ergue-se a poucos metros desta e não recebeu as mesmas reformas da anterior.

A sudoeste de Pinhel ergue-se o castelo de Celorico da Beira, sobranceiro ao rio Mondego e à «estrada da Beira». Este local poderia já estar fortificado no século XII, tendo sido conquistado por D. Afonso Henriques, que dele recebeu foral.

\footnotetext{
352 Trás-os-Montes Medieval e Moderno. Fontes Documentais. Séc. XIV, 2003: doc. 36; Chancelarias Portuguesas: D. Pedro I (1357-1367), 1984: 268.

${ }^{353}$ Chancelarias Portuguesas: D. João I (1410-1425), 2006: vol. IV, tomo 1, 26-27.

${ }^{354}$ Direção-Geral do Património Cultural: http://www.patrimoniocultural.pt.

355 BARROCA, 2000b.

${ }^{356}$ GOMES, 2003: 125-126.

${ }^{357}$ Direção-Geral do Património Cultural: http://www.patrimoniocultural.pt.
} 
"A primeira referência concreta acerca do castelo data de 1198, ano em que a fortaleza se viu cercada por tropas leonesas [...] Desconhece-se, todavia, qual a configuração da fortaleza» ${ }^{358}$. O castelo que chegou até aos nossos dias é, segundo o que parece, obra dos restauros efetuados por D. Dinis. Apresenta uma cerca ovalada e uma torre de menagem adossada aos muros exteriores. Contudo, esta fortaleza teria uma outra torre, no centro do pátio, e próxima da cisterna. Hoje esta construção já não existe, mas parece ter subsistido vestígios dela ${ }^{359}$.

Finalmente o exemplo do castelo de Linhares da Beira (Celorico da Beira, Guarda), que já em tempos de D. Sancho I era uma "povoação acastelada». Mais uma vez se desconhece a configuração desta fortificação primitiva, contudo "É de presumir que se adaptasse ao protótipo de castelo românico, com torre de menagem isolada no interior do recinto fortificado e cerca implantada de acordo com as curvas de nível» ${ }^{360}$. Como tem sido norma, pensa-se que a construção que chegou até nós é da iniciativa de D. Dinis, que terá doado a vila ao seu filho bastardo Fernão Sanches. O castelo tem duas torres, uma delas, a de menagem, situa-se entre os dois recintos da fortaleza, protegendo a porta da alcáçova. A esta torre encosta a muralha que separa os dois recintos. Na vertente nascente ergue-se a segunda torre, fora do segundo recinto muralhado, que parece encostar ao anterior. No interior da alcáçova existiriam duas cisternas e vestígios de um poço. $\mathrm{O}$ castelo teria três portas, uma delas a da traição. Os restauros dos anos 40 e 50 do século XX afetaram profundamente o solo com inúmeros desaterros, prejudicando irremediavelmente uma leitura mais aprofundada do castelo ${ }^{361}$.

Parece evidente, pelo que foi exposto, que nem sempre a observação das estruturas esclarece a natureza das fortificações. Estes edifícios militares atravessaram toda a Idade Média e foram objeto de diversas alterações, não só fruto de adaptações às inovações técnicas e arquitetónicas de cada época, mas também fruto de restauros motivados pelas destruições dos conflitos em que se viram envolvidos.

Para cada castelo haverá uma narrativa, que nem sempre é legível nas suas edificações. Estas podem condicionar a nossa visão e restringir a nossa análise, daí a importância documental como complemento da leitura arquitetónica. Mas serão sem dúvida, os trabalhos arqueológicos a melhor complementarem ou esclarecerem muitas dúvidas. Daí a importância de definir projetos integrais que visem leituras alargadas e não apenas leituras pontuais, cujas conclusões podem ficar aquém das dúvidas levantadas.

\footnotetext{
358 Direção-Geral do Património Cultural: http://www.patrimoniocultural.pt. ${ }^{359}$ MOREIRA, dir., 1989: 46.

${ }^{360}$ Direção-Geral do Património Cultural: http://www.patrimoniocultural.pt.

${ }^{361}$ Direção-Geral do Património Cultural: http://www.patrimoniocultural.pt.
} 

CONCLUSÃO 

O castelo de Outeiro foi durante 500 anos um marco na defesa da fronteira transmontana e um símbolo do poder da Coroa portuguesa. Ponto de vigilância privilegiado, a fortificação ganhou visibilidade a partir do reinado de D. Dinis, altura em que a Coroa assume, de forma definitiva, o controlo da linha fronteiriça que separa os dois reinos ibéricos.

A responsabilidade de povoar estas regiões limítrofes deixa de ser exclusiva das vontades senhoriais ou eclesiásticas, que nos primeiros anos de soberania foram investidas de tais funções. Os monarcas de Duzentos vão reclamar para si o senhorio das terras de fronteira e conceder forais às populações para que se fixem e façam parte de um modelo administrativo delineado pela Coroa. Será à luz desta conjuntura que Outeiro passará para o domínio régio em 1290 e será beneficiado com carta de foro, que pretendia ser um incentivo ao crescimento populacional.

Numa altura em que a Reconquista chega ao fim em território português e que se estabelecem as linhas de fronteira com Castela através do Tratado de Alcañices, em 1297, as atenções da Coroa lusa centram-se na reforma e consolidação das linhas defensivas raianas. Esta política de clarificação e controlo fronteiriços, que segundo a documentação passou primeiro pela fixação e integração administrativa das populações, acabará por ser complementada pela necessidade de defesa, através de uma estrutura militar que garantisse a proteção da terra e das suas povoações.

Será neste cenário que o castelo de Outeiro aparece na primeira linha de defesa da fronteira oriental de Trás-os-Montes, articulando-se com o castelo de Bragança, Vimioso e Miranda do Douro. Para além de vigiar a fronteira, nomeadamente as entradas pela zona de Quintanilha e Pinelo, controlava toda a zona de passagem pelo planalto português que se estende entre Vimioso e Bragança.

Mas o castelo de Outeiro não foi apenas atalaia. Erguido numa região onde a ameaça era uma realidade inevitável, a fortaleza era vista como local de refúgio para as populações da região. Daí o interesse manifestado pelos moradores, em 1355, de construírem uma cerca a par do castelo e aí erguerem as suas casas.

Nos períodos em que as populações beneficiavam de paz, o castelo não perdeu a sua importância pois, para além de garantir a separação dos dois reinos, representava a autoridade e autonomia da Coroa portuguesa.

Erguido por vontade ou com autorização régia, o castelo de Outeiro esteve sob jurisdição da Coroa, que durante anos foi responsável pela nomeação dos seus alcaides. Com D. Fernando a fortaleza vai ser entregue a João Afonso Pimentel, acabando no século XV por integrar os domínios da Casa de Bragança. Em 1640 e com D. João IV a Casa de Bragança passará a ser também a Casa Real, voltando o castelo de Outeiro para os domínios da Coroa.

Durante a Idade Média, e tanto quanto se sabe, o castelo transmontano apenas terá intervindo no conflito entre D. Fernando e D. Henrique II de Castela, acabando por ser 
tomado por este último em 1369. Depois desta campanha só em 1646 teremos notícias de nova incursão castelhana, que destruirá a vila de Outeiro, obrigando a população a refugiar-se no castelo. O derradeiro combate será travado em 1762, ano em que as tropas espanholas queimam e destroem o castelo que já se encontrava abandonado.

Ao longo destes séculos de existência, o castelo de Outeiro passou por diversas fases que moldaram a sua fisionomia arquitetónica. Embora subsista nas plantas que chegaram até nós uma aparente uniformização, pudemos detetar na sua análise diferentes momentos de adaptação que traduzem as transformações que marcaram as principais filosofias militares medievais. Esta análise arquitetónica sustentou-se não só na documentação consultada, como no estudo dos debuxos realizados por Duarte de Armas por volta de 1509 e nas plantas desenhadas no século XVIII por militares.

Uma primeira conclusão retirada deste estudo é que o castelo de Outeiro parece ter tido uma fase cujo modelo se baseia na construção românica de sistemas defensivos. Esta primeira construção é-nos insinuada, sobretudo, pela torre que se ergue isolada no interior do pátio da fortaleza, com uma cisterna ao lado; pela muralha construída sob a penedia, que a leste é rasgada por duas seteiras entaipadas; e pela existência de uma porta da traição, como nos indica Duarte de Armas.

Numa segunda fase, e procurando adaptar o castelo ao modelo de defesa ativa, própria dos castelos góticos, a fortaleza receberá obras na zona sul, construindo-se uma torre de menagem no exterior das muralhas e enquadrando as portas de entrada. Estas, são ambas voltadas a sul, abrindo-se uma delas para a cerca da vila, construída a partir de 1355. As portas obrigam os invasores a atravessar uma série de passagens, protegidas por balcões com matacães e um torreão voltado a leste. A entrada sudoeste é ainda protegida por um antemuro.

Talvez já durante o século XV, e possivelmente a partir de 1442, ano em que o castelo de Outeiro é entregue ao primeiro duque de Bragança, a fortaleza receberá as necessárias adaptações para se tornar um local de residência, erguendo-se alguns edifícios no interior da praça, passando a proporcionar um maior conforto ao alcaide e à sua guarnição. Nas vistas de Duarte de Armas são visíveis a despontar dos telhados duas chaminés, algumas janelas rasgadas nos andares superiores e até uma latrina na zona noroeste da muralha.

Também datáveis do século XV serão as adaptações ao uso de artilharia, visíveis nas zonas de entrada com a abertura de troneiras cruzetadas que foram representadas nas vistas do escudeiro Duarte de Armas.

Finalmente, e possivelmente já em época moderna, o castelo de Outeiro terá sofrido obras nas zonas de entrada, tendo-se fechado o antemuro a sudoeste e reformulado a entrada voltada à cerca, que nas plantas do século XVIII, não apresenta o torreão. Na zona da cerca, que parecia estar livre de construções em 1509, vão ser construídas casas para as tropas, uma capela de invocação a Santa Luzia e um poço. 
De todas as fases de construção, as duas primeiras são as que nos levantam mais dúvidas. A primeira que atribuímos a um período românico teria que ter ocorrido num momento anterior ao reinado de D. Dinis, por isso anterior a 1279. Se já existiria uma fortificação ou algum elemento defensivo, como uma torre ou atalaia, ela não é mencionada nos documentos que consultamos, ficando a dúvida se realmente existiria e de quem foi a iniciativa da sua construção. Se não existia uma fortificação anterior a 1279, sendo esta apenas construída em meados do século XIV, altura em que já se tinha iniciado a adaptação dos castelos às soluções de defesa ativa, como explicar as opções «arcaicas» da torre interior e das seteiras, elementos claros de uma fortificação românica? Parece-nos que a posição estratégica do castelo de Outeiro não passou despercebida ao longo dos séculos. Toda a região está ocupada por sítios fortificados desde a Idade do Ferro, que tinham como objetivo controlar passagens e dominar a paisagem. Em época romana o planalto transmontano foi usado como eixo viário que conduzia às riquezas mineiras da região. Ora em tempos medievais, parece-nos natural que esta região fosse dominada e vigiada, podendo o cabeço de Outeiro ser usado como ponto de vigia, com ou sem construções efetivas.

A segunda fase construtiva do castelo de Outeiro, que já corresponde ao advento das novidades góticas, também não se compreende de forma clara. Sabemos que em 1355, os moradores de Outeiro pedem para fazer vila cercada. Pelo que entendemos não se trataria de cercar a aldeia no vale, mas sim fazer uma cerca no outeiro. Parece-nos que este pedido faria mais sentido se já existisse uma estrutura defensiva que pudesse, juntamente com a cerca, defender os habitantes das ameaças das guerras. Contudo, não se faz referência a nenhuma fortificação. Esta só é claramente referida em 1361, quando D. Pedro I designa João Rodrigues de Basto, como alcaide do castelo de Outeiro.

Embora não tenha sido possível comprovar neste estudo as nossas propostas com dados documentais, julgamos que há indícios que podem sustentar a hipótese da existência de um castelo anterior a 1361. Os parcos elementos observados nas ruínas que hoje são a fortificação levam-nos a acreditar na existência de uma construção românica que poderá ter recebido reformas a partir do reinado de D. Dinis.

Por fim, pensamos que o estudo histórico e arqueológico do castelo de Outeiro será tanto mais relevante se integrar um projeto de preservação e integração dos seus vestígios, que tenha como objetivo devolver a memória da sua existência, contribuindo assim para a valorização da história da região. Não bastará um programa de restauros que tente edificar uma imagem de castelo medieval, símbolo de glórias passadas ou motivo turístico ocasional, que muitas vezes descamba num abandono bem mais infeliz e doloroso para as populações a quem muito se prometeu. 
Nos dias de hoje, em que se exige a aplicação correta dos recursos, será necessário definir um projeto viável, que valorize o património edificado, mas também garanta os meios necessários à divulgação do seu estudo e conhecimento. Por último, não se poderá esquecer as populações, a quem o conhecimento é dirigido, e a quem é pedida a participação na preservação cultural do nosso património. 
FONTES E BIBLIOGRAFIA 



\section{FONTES DOCUMENTAIS}

\section{Arquivo Nacional Torre do Tombo}

ANTT. Chancelaria de D. João II, liv. 26, fol. 106.

ARMAS, Duarte de (2006). Livro das Fortalezas. Intro. Manuel da Silva Castelo Branco. 3. ${ }^{a}$ edição. Lisboa: Arquivo Nacional Torre do Tombo; Edições Inapa. Fac-símile do Ms. 159 da Casa Forte do Arquivo Nacional da Torre do Tombo.

AS GAVETAS DA TORRE DO TOMBO. Intro. António da Silva Rego. Lisboa: Centro de Estudos Históricos Ultramarinos, 1962-1977, vols. II, IV, XI, XII.

BARROS, João de (1919). Geographia d'entre Douro e Minho e Tras-os-Montes. Porto: Tipografia Progresso. (Biblioteca Pública Municipal do Pôrto. Colecção de Manuscritos Inéditos Agora Dados à Estampa; 5).

CAPELA, José Viriato et al. (2007). As freguesias do Distrito de Bragança nas Memórias Paroquiais de 1758. Memórias, História e Património. Braga: [Braga Barbosa \& Xavier Artes Gráficas]. (Coleção Portugal nas Memórias Paroquiais de 1758).

CHANCELARIA DE D. AFONSO III. Ed. de Leontina Ventura e António Resende de Oliveira. Coimbra: Imprensa da Universidade de Coimbra, 2011, livros II e III.

CHANCELARIAS PORTUGUESAS: D. João I (1384-1388). Ed. preparada por João José Alves Dias. Lisboa: Centro de Estudos Históricos da Universidade Nova de Lisboa, 2005, vol. I, tomo 3.

CHANCELARIAS PORTUGUESAS: D. João I (1385-1392). Ed. preparada por João José Alves Dias. Lisboa: Centro de Estudos Históricos da Universidade Nova de Lisboa, 2005, vol. II, tomo 1.

CHANCELARIAS PORTUGUESAS: D. João I (1387-1402). Ed. preparada por João José Alves Dias. Lisboa: Centro de Estudos Históricos da Universidade Nova de Lisboa, 2005, vol. II, tomo 2.

CHANCELARIAS PORTUGUESAS: D. João I (1391-1407). Ed. preparada por João José Alves Dias. Lisboa: Centro de Estudos Históricos da Universidade Nova de Lisboa, 2005, vol. II, tomo 3.

CHANCELARIAS PORTUGUESAS: D. João I (1410-1418). Ed. preparada por João José Alves Dias. Lisboa: Centro de Estudos Históricos da Universidade Nova de Lisboa, 2006, vol. III, tomo 3.

CHANCELARIAS PORTUGUESAS: D. João I (1410-1425). Edição preparada por João José Alves Dias. Lisboa: Centro de Estudos Históricos da Universidade Nova de Lisboa, 2006, vol. IV, tomo 1.

CHANCELARIAS PORTUGUESAS: D. Pedro I (1357-1367). Ed. de A. H. de Oliveira Marques. Lisboa: Instituto Nacional de Investigação Científica; Centro de Estudos Históricos da Universidade Nova de Lisboa, 1984.

COSTA, P. António Carvalho da (1868). Corografia portugueza, e descripçam topografica do famoso Reyno de Portugal. 2. a edição. Braga: Typographia de Domingos Gonçalves Gouveia, tomo I.

DEMARCACÕES DE FRONTEIRA: lugares de Trás-os-Montes e Entre-Douro-e-Minho. Ed. de Humberto Baquero Moreno e Isabel Vaz Freitas. Porto: Centro de Investigação e Documentação de História Medieval, Universidade Portucalense, 2003, vol. III.

DOCUMENTOS DE D. SANCHO I (1174-1211). Ed. de Avelino de Jesus da Costa, Rui de Azevedo e Marcelino Pereira. Coimbra: Centro de História da Universidade de Coimbra, 1979.

FORAIS MANUELINOS DO REINO DE PORTUGAL E DO ALGARVE: Trás-os-Montes. Ed. de Luiz Fernando de Carvalho Dias. Lisboa: [Edição de autor], 1961.

FREIRE, Anselmo Braamcamp (1909). Povoação de Trás os Montes no XVI. Seculo. «Archivo Historico Portuguez». VII:7, 241-290.

LOPES, Fernão (1966). Cronica do Senhor Rei Dom Fernando Nono Rei destes Regnos. Porto: Livraria Civilização Editora. (Biblioteca Histórica. Série Régia).

PORTUGALIAE MONUMENTA HISTORICA. Inquisitiones. Lisboa: Academia das Ciências de Lisboa, 1961, vol. 1, pars I, fasc. VIII. 
SANTANA, Maria Olinda Rodrigues (2008). Documentação foraleira dionisiana de Trás-os-Montes: breve estudo e edição interpretativa. Lisboa: Edições Colibri. (Estudos e ensaios; 6).

SOUSA, D. António Caetano de (1949). Provas da História Genealógica da Casa Real Portuguesa. Coimbra: Atlântida, tomo III, II parte, livro VI.

TRÁS-OS-MONTES MEDIEVAL E MODERNO. Fontes Documentais. Séc. XIV. Ed. de Maria Cristina Cunha Alegre e Paula Pinto Costa. Bragança: Arquivo Distrital de Bragança, 2003.

\section{CARTOGRAFIA}

CARTA Geológica de Portugal. Escala 1:500 000. 5. a edição. [S.l.]: Serviços Geológicos de Portugal, 1992.

CARTA Militar de Portugal. Avelanoso (Vimioso). Escala 1: 25 000. 2. a edição. Série M888. Folha 152. Lisboa: Instituto Geográfico do Exército, 1996.

CARTA Militar de Portugal. Parada (Bragança). Escala 1: 25 000. 2. ${ }^{a}$ edição. Série M888. Folha 51. Lisboa: Instituto Geográfico do Exército, 1996.

\section{BIBLIOGRAFIA}

AFONSO, Ana Maria (2002). O Mosteiro de São Salvador de Castro de Avelãs. In AFONSO, Ana Maria; GASPAR, Diogo, coord. A construção de uma identidade, Trás-os-Montes e Alto Douro. Bragança: Arquivo Distrital de Bragança.

AFONSO, Belarmino (1991). Confrarias e Mentalidades Barroca. Porto: Reitoria da Universidade do Porto; Governo Civil do Porto. Separata das Actas do I Congresso Internacional do Barroco, vol. I.

ALMEIDA, Carlos et al. (2000). Sistemas Aquíferos de Portugal Continental. Lisboa: Centro de Geologia da Universidade de Lisboa; Instituto Nacional da Água.

ALMEIDA, Carlos Alberto Ferreira de (1971). Primeiras impressões sobre a arquitectura românica portuguesa. «Revista da Faculdade de Letras: História». Série I. 2, 65-116.

ALMEIDA, Carlos Alberto Ferreira de (1978). Castelologia Medieval de Entre-Douro-e-Minho: desde as origens a 1220. Porto: FLUP. Dissertação complementar de doutoramento.

ALMEIDA, João de (1946-1947). Roteiro dos Monumentos Militares Portugueses. Lisboa: [Edição de Autor], vols. I-III.

ALVES, Francisco Manuel (Abade de Baçal) (1940). Aforamento de propriedades em Outeiro na Era de 1308 (Ano de Cristo 1270). In Congresso do Mundo Português. Lisboa: Comissão Executiva dos Centenários, vol. II.

ALVES, Francisco Manuel (Abade de Baçal) (2000). Memórias Arqueológico-Históricas do Distrito de Bragança. Bragança: Câmara Municipal de Bragança. 11 vols.

AMADO, Adrião Martins (1946). Durante o Ostracismo. «O Instituto. Revista Científica e Literária». 108, 220-238.

ANDRADE, Amélia Aguiar (2001). A construção Medieval do Território. Lisboa: Livros Horizonte.

ANDRÉ, Clara (2008). Projecto VIAS AVGVSTAS e traçado da Via XVII do itinerário de Antonino. In MENÉNDEZ, Jorge Argüello, coord. Bragança, um Olhar Sobre a História. Bragança: Câmara Municipal de Bragança, vol. II.

CABALLERO ARENCIBIA, Agustín; BAPTISTA, Emidio; SERRANO; Silvia, coord. (2007). Frontera y Desarrollo: Estudio del espacio de frontera Salamanca, Tras-os-Montes y Alto Duero. 1. a edição. Salamanca: Ediciones de la Diputación de Salamanca. 
AZEVEDO, Ruy de (1937). Período de formação territorial: expansão pela conquista e sua consolidação pelo povoamento. As terras doadas. Agentes colonizadores. In BAIÃO, António. História da Expansão Portuguesa no Mundo. Lisboa: Editorial Ática, vol. I.

AZUAR, Rafael (2013). Arqueología de los hûsûn en la formación y consolidación del Sharq al-Andalus (siglos VIII-X $d C$ ). In FERNANDES, Isabel Cristina Ferreira, coord. Fortificações e Território na Península Ibérica e no Magreb (Séculos VI a XVI). Lisboa: Edições Colibri; Mértola: Campo Arqueológico de Mértola, vol. I.

BARATA, Manuel Themudo; TEIXEIRA, Nuno Severiano, dir. (2003). Nova História Militar de Portugal. Lisboa: Círculo de Leitores, vol. 1.

BARBOSA, Pedro Gomes (1997). Sistemas Defensivos de Fronteira, na "Reconquista" (Séculos IX-Inícios do XII). In COMISSÃO PORTUGUESA DE HISTÓRIA MILITAR, org. Preparação e Formação Militar em Portugal: VIII Colóqio: Actas. Lisboa: Comissão Portuguesa de História Militar.

BARROCA, Mário Jorge (1990-1991). Do castelo da reconquista ao castelo românico (Séc. IX a XII). «Portugália». Nova Série. XI-XII, 89-136.

BARROCA, Mário Jorge (1996-1997). A Ordem do Templo e a Arquitectura Militar Portuguesa do Século XII. «Portugália». Nova Série. XVII-XVIII, 171-209.

BARROCA, Mário Jorge (1998). D. Dinis e a arquitectura militar portuguesa. «Revista da Faculdade de Letras: História». Série II. 15: 1, 801-822.

BARROCA, Mário Jorge (2000a). Aspectos da evolução da arquitectura militar da Beira Interior. In BEIRA INTERIOR - História e Património: Actas das I Jornadas de Património da Beira Interior. Guarda: Câmara Municipal da Guarda, pp. 215-238.

BARROCA, Mário Jorge (2000b). Castelo de Freixo de Espada à Cinta. In ROSAS, Lúcia; BARROCA, Mário Jorge. Do Douro Internacional ao Côa: as raízes de uma fronteira. Porto: IDH-FLUP.

BARROCA, Mário Jorge (2001). Castelos românicos portugueses (Séc. XII e XIII). In VALLE PÉREZ, Xosé Carlos; RODRIGUES, Jorge, coord. Românico em Portugal e na Galiza. A Coruña: Fundación Pedro Barrié de la Maza; Lisboa: Fundação Calouste Gulbenkian, pp. 88-111. Catálogo de exposição.

BARROCA, Mário Jorge (2002). Os castelos das Ordens Militares em Portugal (Séculos XII a XIV). In FERNANDES, Isabel Cristina Ferreira. Mil Anos de Fortificações na Península Ibérica e no Magreb (500-1500): Actas do Simpósio Internacional sobre Castelos 2000. Lisboa: Edições Colibri; Palmela: Câmara Municipal de Palmela, pp. 535-548.

BARROCA, Mário Jorge (2003a). Da Reconquista a D. Dinis. In BARATA, Manuel Themudo; TEIXEIRA, Nuno Severiano, dir. Nova História Militar de Portugal. Lisboa: Círculo de Leitores, vol. 1, pp. 21-161.

BARROCA, Mário Jorge (2003b). Uma paisagem com castelos. In JORGE, Vítor Oliveira, coord. Arquitectando espaços: da natureza à metapolis. Porto: Departamento de Ciências e Técnicas do Património, FLUP.

BARROCA, Mário Jorge (2004a). Fortificações e Povoamento no Norte de Portugal (Séc. IX a XI). «Portugália». Nova Série. XXV, 181-203.

BARROCA, Mário Jorge (2004b). Tempos de Resistência e de inovação: a arquitectura militar portuguesa do Reinado de D. Manuel I (1495-1521). Guimarães: Câmara Municipal de Guimarães. Separata das Actas do III Congresso Histórico de Guimarães - D. Manuel e a sua época, vol. IV.

BARROCA, Mário Jorge (2008-2009). De Miranda do Douro ao Sabugal - Arquitectura militar e testemunhos arqueológicos medievais num espaço de fronteira. «Portugália». Nova Série. XXIX-XXX, 193-252.

BARROCA, Mário Jorge; MONTEIRO, João Gouveia (2000). Pera Guerrejar. Armamento Medieval no Espaço Português. Palmela: Câmara Municipal de Palmela. Catálogo da exposição. 
BARROS, Amândio Jorge Morais (1998). Uma contenda a norte da "Contenda» (alguns aspectos das relações fronteiriças entre Portugal e Castela na Idade Média). «Revista da Faculdade de Letras: História». Série II, 15: 1, 324-364.

BARROS, Henrique da Gama (1945-1954). História da Administração Pública em Portugal nos Séculos

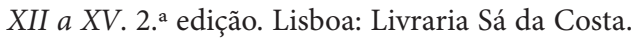

BEÇA, Humberto (1923). Castelos de Hespanha, Castelos de Portugal. Madrid: Asociación Española para el Progreso de las Ciencias.

BECEIRO PITA, Isabel (1998). Los poderes señoriales en los territorios fronterizos al norte del Duero (siglo XIII-inicios del XIV). «Revista da Faculdade de Letras: História». Série II. 15: 2, 1085-1100.

CAPELA, Mafalda et al. (2004). Trabalhos Arqueológicos no âmbito da Sociedade Bragança Polis. In LIMA, António; ARGÜELLO MENÉNDEZ, Jorge, coord. Bragança, um olhar sobre a História. Bragança: Câmara Municipal de Bragança, pp. 31-94.

CASTRO, José de (1946-1951). Bragança e Miranda. Porto: Tipografia Porto Médico.

CÉSAR, Amândio (1959). Antologia da Terra Portuguesa. Trás-os-Montes e Alto Douro. Lisboa: Livraria Bertrand.

CHAVES, Luís (1930). Os Pelourinhos Portugueses. Gaia: Edições Apolino.

COBOS GUERRA, Fernando; CASTRO FERNÁNDEZ, José Javier de (1998). Castillos y Fortalezas. Castilla y León. Madrid: Edilesa.

COELHO, Maria Helena da Cruz (1989-1990). Relações de domínio no Portugal concelhio de meados de Quatrocentos. «Revista Portuguesa de História». XXV, 235-289.

COELHO, Maria Helena da Cruz (2008). D. João I. 1. a edição. Lisboa: Temas e Debates. (Reis de Portugal).

CORREIA, Luís Miguel Maldonado de Vasconcelos (2010). Castelos em Portugal. Retrato do seu perfil arquitectónico. Coimbra: Imprensa da Universidade de Coimbra.

CORREIA, Vergílio (1919). Caminho de Miranda (Apontamentos de Viagem). «A Águia». 2. ${ }^{\text {a Série. }}$ XVI, 154-162.

COSTA, Paula Pinto (2004-2005). Bragança medieval no contexto transmontano. A memória legada pelos pergaminhos conservados no Arquivo Distrital de Bragança. «Brigantia: Revista de Cultura». 24: 3/4, 25: 1/2, 47-58.

CRUZ, Abel dos Santos (1998). O problema da fronteira na vida militar dos concelhos ao tempo do rei D. João I: exemplos da Chancelaria Real. «Revista da Faculdade de Letras: História». II Série. 15: 1, 577-600.

CRUZ VILLALÓN, Maria (2013). Castillos y cercas medievales a traves de fuentes de la Edad Moderna. Extremadura y Alentejo. In FERNANDES, Isabel Cristina Ferreira, coord. Fortificações e Território na Península Ibérica e no Magreb (Séculos VI a XVI). Lisboa: Edições Colibri; Mértola: Campo Arqueológico de Mértola, vol. I.

CUNHA, Mafalda Soares da (1990). Linhagem, parentesco e poder: a Casa de Bragança (1384-1483). Lisboa: Fundação Casa de Bragança.

CUNHA, Maria Cristina (2002). A escrita e os documentos avulsos do Mosteiro de Castro de Avelãs. In AFONSO, Ana Maria; GASPAR, Diogo, coord. A construção de uma identidade. Trás-os-Montes e Alto Douro. Bragança: Arquivo Distrital de Bragança, pp. 50-52.

D’EÇA, Almeida (1925). Castles of Portugal. Lisboa: Secretaria de Estado da Informação e Turismo.

DAVEAU, Suzanne (1995). Portugal geográfico. Lisboa: Edições João Sá da Costa.

DIAS, João José Alves (1992). Gentes e Espaços (em torno da população portuguesa na primeira metade do século XVI). Lisboa: Universidade Nova de Lisboa. Tese de doutoramento. 
DIAS, Nuno Pizarro (1990). As cidades de fronteira de Portugal com a Galiza. «Cadernos do Noroeste». 3:1-2, 81-102.

DIONíSIO, Sant’Anna (1995). Guia de Portugal. Trás-os-Montes e Alto-Douro. II - Lamego, Bragança e Miranda. 3. ${ }^{a}$ edição. Lisboa: Fundação Calouste Gulbenkian, vol. 5, tomo 2.

FELGUEIRAS, Francisco (1968). Monografias Bragançanas. Outeiro. Bragança: [s.n.]. Separata do Boletim «Amigos de Bragança».

FERNANDES, A.; RODRIGUES, Luís Alexandre (2004). Monografia das freguesias do concelho de Bragança. Bragança: Câmara Municipal de Bragança.

FERREIRA, Manuel Duarte (2011). Mogadouro 1509: Duarte de Armas descodificado. [Mogadouro]: [Edição de autor].

FREITAS, Isabel Vaz de (2009). Bragança na Idade Média. Muito mais que uma terra da raia. In FERNANDES, Armando, coord. Bragança marca a história, a história marca Bragança. Bragança: Câmara Municipal de Bragança, capítulo III.

GARRIDO, César (1981). Outeiro. Apontamento Monográfico. «Brigantia: Revista de Cultura». 1, 109-119.

GOMES, Paulo Dórdio (1993a). O povoamento medieval em Trás-os-Montes e Alto Douro. Primeiras impressões e hipóteses de trabalho. «Arqueologia Medieval». 2, 171-189.

GOMES, Paulo Dórdio (1993b). Arqueologia das vilas urbanas de Trás-os-Montes e do Alto Douro. A reorganização do povoamento e dos territórios na Baixa Idade Média (séculos XII-XV). Porto: Faculdade de Letras da Universidade do Porto. Dissertação de mestrado.

GOMES, Paulo Dórdio (2010). Trás-os-Montes e o Alto Douro: a definição do território da monarquia portuguesa na Idade Média à secundarização de um espaço regional. In ÁLVAREZ, Milagros Burón; RODRIGUES, Miguel C. Areosa, coord. Actas Coloquio Internacional Patrimonio Cultural $y$ Territorio en el Valle del Duero, pp. 257-276.

GOMES, Rita Costa (1991). A Construção das Fronteiras. In BETHENCOURT, Francisco; CURTO, Diogo Ramada, ed. A Memória da Nação. Lisboa: Livraria Sá da Costa Editora, pp. 357-382.

GOMES, Rita Costa (1995). A Corte dos Reis de Portugal no Final da Idade Média. Lisboa: Difel. (Memória e Sociedade).

GOMES, Rita Costa (2003). Castelos da Raia. Trás-os-Montes. Lisboa: Instituto Português do Património Arquitectónico.

GOMES, Rita Costa (2009). D. Fernando. 1. a edição. Lisboa: Temas e Debates. (Reis de Portugal).

GONZÁLEZ JIMÉNEZ, Manuel (1998). Las relaciones entre Portugal y Castilla durante el siglo XIII. «Revista da Faculdade de Letras: História». Série II. 15: 1, 1-24.

GONZÁLEZ SIMANCAS, Manuel (1910-1911). Plazas de guerra y castillos medioevales de la frontera de Portugal. (Estudios de arquitectura militar.). Madrid: Tip. de la Revista de Archivos, Bibliotecas y Museos.

GUTIÉRREZ GONZÁLEZ, J. Avelino; SUÁREZ MANJÓN, Patricia; JUMÉNEZ CHAPARRO, J. Ignacio (2013). Inventario de Fortificaciones medievales a través de los SIG. In FERNANDES, Isabel Cristina Ferreira, coord. Fortificações e Território na Península Ibérica e no Magreb (Séculos VI a XVI). Lisboa: Edições Colibri; Mértola: Campo Arqueológico de Mértola, vol. II, pp. 541-553.

GRAVE, João (193?). Castellos Portuguezes. Porto: Lello \& Irmão.

HISTÓRIA de Portugal. Cronologia e biografias de monarcas e presidentes. 1. ${ }^{a}$ edição. Lisboa: Texto Editora, 2000. (Colecção Universal).

LEAL, Augusto Soares d'Azevedo Barbosa de Pinho (1875). Portugal Antigo e Moderno. Diccionario Geographico, Estatistico, Chorographico, Heraldico, Archeologico, Historico, Biographico e Etymologico de todas as cidades, villas e freguezias de Portugal, de grande numero de aldeias. Lisboa: Livraria Editora de Mattos Moreira \& Companhia, vol. Sexto. 
LEAL, Sebastião da Silva (1910). Pelourinhos de Traz-os-Montes. XII Outeiro. «A Ilustração Transmontana». 3..$^{\circ}$ ano, 154

LEMOS, Francisco de Sande (1993). Povoamento Romano de Trás-os-Montes Oriental. Braga: Universidade do Minho. Tese de doutoramento. 3 vols.

LEMOS, Francisco de Sande (2002). Trás-os-Montes Povoamento Proto-histórico e Romanização. In A construção de uma identidade, Trás-os-Montes e Alto Douro. Bragança: Arquivo Distrital de Bragança, pp. 40-43.

LEMOS, Francisco de Sande (2009). Da Proto-História à Romanização. In FERNANDES, Armando, coord. Bragança marca a história, a história marca Bragança. Bragança: Câmara Municipal de Bragança, cap. II, pp. 103-111.

LIMA, António; ARGÜELLO MENÉNDEZ, Jorge, coord. (2004). Bragança, um olhar sobre a História. Bragança: Câmara Municipal de Bragança, vol. 1.

LIMA, António Manuel de Carvalho (2013). Fortificações e vias de comunicação no curso terminal do Douro (Séculos IX-XI). In FERNANDES, Isabel Cristina Ferreira, coord. Fortificações e Território na Península Ibérica e no Magreb (Séculos VI a XVI). Lisboa: Edições Colibri; Mértola: Campo Arqueológico de Mértola, vol. I, pp. 183-198.

LOPO, Albino dos Santos Pereira (1987). Apontamentos Arqueológicos. Braga: Instituto Português do Património Cultural.

MACEDO, Jorge Borges de (1991). Unidade, transição e ajustamento na evolução militar portuguesa - séculos XII a XV (1139 a 1495). Ensaios de sintese crítica. In Actas do II Colóquio Panorama e perspectivas actuais da história militar em Portugal. Lisboa: Comissão Portuguesa da História, pp. 397-428.

MAGRO, Maria Virgínia Antão Pêga (2011). Vilar Maior - Evolução de um castelo e povoado raiano de Riba-Côa (séc. XI a XV). Porto: Faculdade de Letras da Universidade do Porto. Dissertação de mestrado.

MALAFAIA, Eurico de Ataíde (2005). Pelourinhos Portugueses. Lisboa: Imprensa Nacional-Casa da Moeda. (Colecção Presenças da Imagem).

MANSO PORTO, Carmen (1999). Cartografia Histórica Portuguesa. Catálogo de Manuscritos (Siglos XVII-XVIII). Madrid: Real Academia de la História.

MARQUES, José (1981). O estado dos mosteiros beneditinos da arquidiocese de Braga no século XV. Braga: Câmara Municipal de Braga. Separata de «Bracara Augusta». 35: 79-80 (92-93), 81-170.

MARQUES, José (1988). Povoamento e Defesa na Estruturação do Estado Medieval Português. «Revista de História». 8, 9-34.

MARQUES, José (1991). A presença da Igreja na História Militar Portuguesa: das Origens aos finais do século XIV. «Revista da Faculdade de Letras: História». Série II. 8, 9-28.

MARQUES, José (1993). Os municípios portugueses dos primórdios da nacionalidade ao fim do reinado de D. Dinis. Alguns aspectos. «Revista da Faculdade de Letras: História». Série II. 10, 71-90.

MARQUES, José (1995). Aspectos do povoamento do Norte de Portugal nos séculos XIII-XIV. Guimarães: [s.n.]. Separata das Actas do Congresso Histórico Comemorativo dos 150 Anos do Nascimento de Alberto Sampaio, pp. 209-234.

MARQUES, José (1998a). Os municípios transmontanos nos séculos XII-XIV. Alguns aspectos. In O Município no Mundo Português. Seminário Internacional. 1. a edição. Funchal: Centro de Estudos de História do Atlântico, pp. 7-36. (Colecção História do Municipalismo; 1).

MARQUES, José (1998b). Os municípios na estratégia defensiva dionisina. «Revista da Faculdade de Letras: História». Série II. 15: 1, 523-544. 
MARQUES, José (2002). Povoamento transmontano. In AFONSO, Ana Maria; GASPAR, Diogo, coord. A construção de uma identidade, Trás-os-Montes e Alto Douro. Bragança: Arquivo Distrital de Bragança, pp. 44-49.

MARQUES, José (2004-2005). Estruturação administrativa e social do nordeste transmontano, no período medieval. Alguns aspectos. «Brigantia: Revista de Cultura». 24: 3/4, 25: 1/2, 3-46.

MARTÍN MARTÍN, José Luís (1998). Conflictos luso-castellanos por la raya. «Revista da Faculdade de Letras: História". Série II. 15:1, 259-273.

MARTINS, Miguel Gomes (2013). Guerreiros Medievais Portugueses. 1. ${ }^{a}$ edição. Lisboa: A Esfera dos Livros.

MATTOSO, José; DAVEAU, Suzanne; BELO, Duarte (2011). Portugal. O Sabor da Terra. Um retrato histórico e geográfico por regiões. Lisboa: Círculo de Leitores; Temas e Debates.

MATTOSO, José (1985). Identificação de um País. Ensaio sobre as Origens de Portugal (1096-1325). 2. ${ }^{\text {a }}$ edição. Lisboa: Editorial Estampa.

MATTOSO, José, dir. (1993-1994). História de Portugal. Lisboa: Editorial Estampa, vols. I e II.

MELO, Arnaldo Rui Azevedo de Sousa (1998). Relações interconcelhias no reinado de D. Dinis. «Revista da Faculdade de Letras: História». Série II. 15: 1, 545-575.

MENDES, José M. Amado (1985). Trás-os-Montes nos finais do século XVIII (alguns aspectos económicosociais). 2. a edição. Bragança: Instituto Politécnico de Bragança. Separata da revista «Estudos Contemporâneos». 1, 9-44.

MENDONÇA, Manuela (1995). Cidades, Vilas e Aldeias de Portugal. Estudos de história regional portuguesa. Lisboa: Edições Colibri, vol. I. (Colibri História; 8).

MONTEIRO, João Gouveia (1997a). A Guerra em Portugal nos finais da Idade Média. Coimbra: Faculdade de Letras da Universidade de Coimbra. Tese de doutoramento.

MONTEIRO, João Gouveia (1997b). A Formação Marcial dos Guerreiros Medievais Portugueses. A Teoria e a Prática. In COMISSÃO PORTUGUESA DE HISTÓRIA MILITAR, org. Preparação e Formação Militar em Portugal: VIII Colóquio. Actas. Lisboa: Comissão Portuguesa de História Militar, pp. 51-58.

MONTEIRO, João Gouveia (1999). Os castelos portugueses dos finais da Idade Média: presença, perfil, conservação, vigilância e comando. Coimbra: Faculdade de Letras da Universidade de Coimbra; Lisboa: Edições Colibri.

MONTEIRO, João Gouveia (2002). Reformas Góticas nos Castelos Portugueses ao longo do séc. XIV e na primeira metade do séc. XV. In MÃO DE FERRO, Fernando, ed. lit.; FERNANDES, Isabel Cristina Ferreira, org. Mil Anos de Fortificações na Península Ibérica e no Magreb (500-1500). Actas do Simpósio Internacional sobre Castelos. Lisboa: Edições Colibri; Palmela: Câmara Municipal de Palmela, pp. 659-666.

MONTEIRO, João Gouveia (2003). De D. Afonso IV (1325) à Batalha de Alfarrobeira (1449) - os desafios da maturidade. In BARATA, Manuel Themudo; TEIXEIRA, Nuno Severiano, dir. Nova História Militar de Portugal. Lisboa: Círculo de Leitores, vol. 1, pp. 163-286.

MONTEIRO, Maria do Loreto; FIGUEIREDO, Tomás de (2009). Geografia. Terra sulcada de rios e inundada de cores. In FERNANDES, Armando, coord. Bragança marca a história, a história marca Bragança. Bragança: Câmara Municipal de Bragança, cap. I, pp. 13-22.

MORA FIGUEROA, Luis de (1987). Arquitectura militar cristiana de la Edad Media española: estado de la cuestión. In Arqueologia Medieval Espanõla. II Congreso. Madrid: Comunidad de Madrid, vol. 1, tomo 1: Ponencias, pp. 49-58.

MOREIRA, Rafael, dir. (1989). Portugal no mundo. História das fortificações portuguesas no mundo. Lisboa: Publicações Alfa. 
MORENO, Humberto Baquero (1974). Elementos para o estudo dos coutos de homiziados instituídos pela coroa. «Portugaliae Historica». 2, 13-63.

MORENO, Humberto Baquero (1982). Linhas de comunicação em Trás-os-Montes no século XV. Porto: [s.n]. Separata do «Boletim do Arquivo Distrital do Porto». 1, 5-16.

MORENO, Humberto Baquero (1986a). Vias portuguesas de peregrinação a Santiago de Compostela na Idade Média. «Revista da Faculdade de Letras: História». Série II. 3, 79-89.

MORENO, Humberto Baquero (1986b). Os municípios portugueses nos séculos XIII a XIV: estudos de história. Lisboa: Editorial Presença.

MORENO, Humberto Baquero (1986c). Os castelos medievais. Vila Nova de Gaia: Gabinete de História e Arqueologia. Separata da «Gaya: Revista do Gabinete de História e Arqueologia». 4, 19-24.

MORENO, Humberto Baquero (1991). A organização militar em Portugal nos séculos XIV e XV. Porto: «Revista da Faculdade de Letras: História». Série II. 8, 29-42.

MORENO, Humberto Baquero (1993). Os confrontos fronteiriços entre D. Afonso V e os reis católicos. «Revista da Faculdade de Letras: História». Série II. 10, 103-116.

MORENO, Humberto Baquero (1995a). Alcaidarias dos castelos durante a regência do Infante D. Pedro. «Revista de História». 13, 35-50.

MORENO, Humberto Baquero (1995b). A consolidação de Portugal na Idade Média. Lisboa: Comissão Portuguesa de História Militar. Separata das Actas do VI Colóquio de História Militar, pp. 1-6.

MORENO, Humberto Baquero (1996). Portugal e a fronteira com Castela no século XIV. Porto: Universidade do Porto. Separata de III Jornadas de Estudo Norte de Portugal-Aquitânia. Actas, n. ${ }^{\circ} 3$, pp. 195-200.

MORENO, Humberto Baquero (1996-1997). Relações entre os reinos peninsulares: (1290-1330). «Anales de la Universidad de Alicante». 11, 29-41.

MORENO, Humberto Baquero (1998a). Conflitos fronteiriços hispano-portugueses nos finais da Idade Média. «Revista de Ciências Históricas». 13, 11-30.

MORENO, Humberto Baquero (1998b). As relações de fronteira no século de Alcañices (1250-1350): o tratado de Alcañices. «Revista da Faculdade de Letras: História». Série II. 15: 1, 641-653.

MORENO, Humberto Baquero (2007). A fronteira hispano-portuguesa nos fins da Idade Média. In HERBERS, Klaus; JASPERT, Nikolas, ed. Grenzräume und Grezüberschreitungen im Vergleich. Der Osten und der Westen des mittelalterlichen Lateineuropa. Berlin: Akademie Verlaz, pp. 323-335.

MOTA, José Peixoto Pinto da (2004-2005). A identidade histórica de algumas aldeias transmontanas: subsídios para o seu estudo. Outeiro. «Brigantia: Revista de Cultura». 24: 3/4, 25: 1/2, 59-80.

MOUTINHO, Mário (1995). A Arquitectura Popular Portuguesa. 3. a edição. Lisboa: Editorial Estampa. NIETO GONZÁLEZ, José Ramón (1983). Damian Bustamante y su obra Portuguesa. «Mundo da Arte. Revista de Arte, Arqueologia e Etnografia». 13, 2-11.

NUNES, António Lopes Pires (2005). Dicionário de Arquitectura Militar. Casal de Cambra: Caleidoscópio.

OUTEIRO. In Grande Enciclopédia Portuguesa e Brasileira. Lisboa; Rio de Janeiro: Editorial Enciclopédia, vol. XIX.

PALACIOS ONTALVA, J. Santiago (2013). Las fortificaciones en la Crónica del rey Don Pedro: percepciones contemporáneas de los escenarios del poder a mediados del s. XIV. In FERNANDES, Isabel Cristina Ferreira, coord. Fortificações e Território na Península Ibérica e no Magreb (Séculos VI a XVI). Lisboa: Edições Colibri; Mértola: Campo Arqueológico de Mértola, vol. I, pp. 109-122.

PERES, Damião (1969). Castelo de Outeiro de Miranda. In PERES, Damião, coord. A gloriosa história dos mais belos castelos de Portugal. Barcelos: Portucalense Editora, pp. 219-220.

PIMENTA, Cristina (2007). D. Pedro I. 1. a edição. Lisboa: Temas e Debates. (Reis de Portugal). 
PIZARRO, José Augusto de Sotto-Mayor (2007). O regime senhorial na fronteira do nordeste português. Alto Douro e Riba Côa (séculos XI-XIII). «Hispânia». 67: 227, 849-880.

PIZARRO, José Augusto de Sotto-Mayor (2008). D. Dinis. 1. a edição. Lisboa: Temas e Debates. (Reis de Portugal).

PLANO Director Municipal de Bragança. Bragança: Câmara Municipal de Bragança, 2009.

PORTUGAL. Ministério da Cultura (1997). Decreto n. ${ }^{\circ}$ 67/97. «Diário da República. Série I-B». 301 (1997-12-31) 6892-6903.

PORTUGAL. Ministério da Instrução Pública - Direcção-Geral de Belas Artes (1927). Decreto n. ${ }^{\circ} 14615$. «Diário do Gôverno. Série I». 260 (1927-11-24) 2248-2248.

PORTUGAL. Ministério da Instrução Pública - Direcção-Geral do Ensino Superior e das Belas Artes (1933). Decreto-lei n. ${ }^{\circ} 23122$. «Diário do Gôverno. Série I». 231 (1933-10-11) 1736-1737.

QUINTANILLA RASO, María Concepción (1987). Consideraciones sobre las fortalezas de la frontera castellano-portuguesa de la Baja Edad Media. In MORENO, Humberto Baquero; FONSECA, Luís Adão; MARQUES, José, coord. Actas das II Jornadas Luso-Espanholas de História Medieval. Porto: Instituto Nacional de Investigação Científica, vol. I.

REIS, António Matos (2002). Origens dos municípios portugueses. 2. a edição. Lisboa: Livros Horizonte. RIBEIRO, António (2004). O Nordeste (Trás-os-Montes Oriental). In FEIO, Mariano; DAVEAU, Suzanne, org. O Relevo de Portugal. Grandes Unidades Regionais. Coimbra: Associação Portuguesa de Geomorfólogos, vol. II, pp. 127-131.

RIBEIRO, Orlando; LAUTENSACH, Hermann; DAVEAU, Suzanne (1987). Geografia de Portugal. A posição geográfica e o território. 1. a edição. Lisboa: Edições João Sá da Costa, vol. I.

RIBEIRO, Orlando; LAUTENSACH, Hermann; DAVEAU, Suzanne (1988). Geografia de Portugal. O ritmo climático e a paisagem. 1. a edição. Lisboa: Edições João Sá da Costa, vol. II.

RIBEIRO, Orlando; LAUTENSACH, Hermann; DAVEAU, Suzanne (1989). Geografia de Portugal. O povo português. 1. ${ }^{\text {a }}$ edição. Lisboa: Edições João Sá da Costa, vol. III.

RIBEIRO, Orlando; LAUTENSACH, Hermann; DAVEAU, Suzanne(1991). Geografia de Portugal. A vida económica e social. 1. ${ }^{a}$ edição. Lisboa: Edições João Sá da Costa, vol. IV.

RODRIGUES, Luís Alexandre (2001). De Miranda a Bragança: arquitectura religiosa de função paroquial na época moderna. Porto: FLUP. Tese de doutoramento.

RODRIGUES, Luís Alexandre, coord. (2005). O Património Histórico-Cultural da Região de Bragança / Zamora. Porto: CEPESE; Edições Afrontamento.

SANTANA, Maria Olinda Rodrigues (2002). Documentação foraleira de Trás-os-Montes. In AFONSO, Ana Maria; GASPAR, Diogo, coord. A construção de uma identidade, Trás-os-Montes e Alto Douro. Bragança: Arquivo Distrital de Bragança, pp. 60-61.

SANTANA, Maria Olinda Rodrigues (2009). Poder senhorial e direitos de foral. In FERNANDES, Armando, coord. Bragança marca a história, a história marca Bragança. Bragança: Câmara Municipal de Bragança, capítulo III, pp. 115-120.

SANTOS, Joaquim Manuel Rodrigues dos (2012). A Castelologia Portuguesa e a evolução dos estudos sobre Fortificações Medievais em Portugal. «Portvgalia». Nova Série. 33, 107-143.

SANTOS, Joaquim Manuel Rodrigues dos (2013). Construção da imagem, forma e (re)funcionalização na reabilitação de castelos medievais em Portugal. In FERNANDES, Isabel Cristina Ferreira, coord. Fortificações e Território na Península Ibérica e no Magreb (Séculos VI a XVI). 1. a edição. Lisboa: Edições Colibri; Mértola: Campo Arqueológico de Mértola, vol. II, pp. 705-716.

SERRÃO, Joel; MARQUES, A. H. de Oliveira, dir. (1987). Nova História de Portugal. 1. a edição. Lisboa: Editorial Presença. Vol. 4 Portugal na Crise dos Séculos XIV e XV. A. H. Oliveira Marques. 
SERRÃO, Joel; MARQUES, A. H. de Oliveira, dir. (1996). Nova História de Portugal. 1. a edição. Lisboa: Editorial Presença. Vol. 3. Portugal em Definição de Fronteiras (1096-1325). Do Condado Portucalense à Crise do Século XIV. Coord. Maria Helena da Cruz Coelho e Armando Luís de Carvalho Homem. SOTO RÁBANOS, José María (1998). La frontera en la ideologia eclesial: el caso luso-castellano (12501450). «Revista da Faculdade de Letras: História». Série II. 15: 1, 729-742.

SOUSA, Armindo de (1998). Fronteira e representação parlamentar na Idade Média portuguesa. «Revista da Faculdade de Letras: História». Série II. 15: 1, 54-61.

SOUSA, Bernardo Vasconcelos e (2009). D. Afonso IV. 1. a edição. Lisboa: Temas e Debates. (Reis de Portugal).

STABEL-HANSEN, Juan Sozaya (2008). La trama defensiva del valle del Duero. In MARTÍ, Ramón, coord. Actas do Congresso Fars de l'islam antigues alimares d'al-Andalus. Edar: Editora Edar, pp. 89-121.

TABORDA, Vergílio (1987). Alto Trás-os-Montes. Estudo Geográfico. 2. a edição. Lisboa: Livros Horizonte. (Colecção Espaço e Sociedade).

TAVARES, Maria José Pimenta Ferro (1983). A nobreza no reino de D. Fernando e a sua actuação em 1383-1385. «Revista de História Económica e Social». 12, 45-89.

VENTURA, Leontina (1998). A fonteira luso-castelhana na Idade Média. «Revista da Faculdade de Letras: História». Série II. 15: 1, 25-52.

VERDELHO, Pedro (2000). Roteiro dos castelos de Trás-os-Montes. Castelo de Outeiro. Chaves: Câmara Municipal de Chaves, pp. 71-75.

VITERBO, Joaquim de Santa Rosa de (1965-1966). Elucidário das palavras, termos e frases que em Portugal antigamente se usaram e que hoje regularmente se ignoram: obra indispensável para entender sem erro os documentos mais raros e preciosos que entre nós se conservam. 2. a edição. Lisboa: Civilização, tomos I e II.

\section{WEBGRAFIA}

ARQUIVO Nacional Torre do Tombo. [Consult. 23 jul. 2014]. Disponível em <http://antt.dglab.gov.pt $>$. BIBLIOTECA Digital Hispánica. [Consult. 14 fev. 2014]. Disponível em <http://bdh.rd.bne.es>.

ALDEIA de Outeiro. Blogue de Henrique Miguel Martins e Paulo Rodrigues. [Consult. 8 jul. 2015]. Disponível em <http://outeirobrg.com.sapo.pt $>$.

CÂMARA Municipal de Bragança. [Consult. 02 jul. 2015]. Disponível em <http://www.cm-braganca.pt>.

CARTAS, Plantas, Esboços e Projectos: Cartografia Militar Portuguesa. Séculos XVIII-XIX. [Consult. 1 fev. 2014]. Disponível em $<$ http://sidcarta.exercito.pt $>$.

DIREÇÃO-GERAL do Património Cultural. [Consult. 1 mar. 2015]. Disponível em <http://www. patrimoniocultural.pt>.

DIREÇÃO Regional de Cultura Norte. [Consult. 11 ago. 2015]. Disponível em <http://www.culturanorte.pt>. GOOGLE Earth. Image, 2015 DigitalGlobe. Data das imagens: 19 set. 2011.

PORTAL do arqueólogo. [Consult. 20 jul. 2015]. Disponível em <http://arqueologia.patrimoniocultural.pt $>$. PROJECTO Povo Zoela. [Consult. 15 jul. 2015]. Disponível em <http://projetozoelas.wix.com>.

BIBLIOTECA Digital Real Academia de la Historia. [Consult. 14 fev. 2014]. Disponível em <http:// bibliotecadigital.rah.es>.

SISTEMA de Informação para Documentação Cartográfica: o espólio da Engenharia Militar Português. [Consult. 10 fev. 2014]. Disponível em <http://sidcarta.exercito.pt $>$.

SISTEMA de Informação para o Património Arquitetónico (SIPA). [Consult. 1 mar. 2015]. Disponível em: <http://www. monumentos.pt $>$.

VISITAR Portugal. Enciclopédia das localidades portuguesas. [Consult. 03 set. 2015]. Disponível em $<$ http://www.visitarportugal. pt $>$. 
MAPAS, DESENHOS
E PLANTAS 



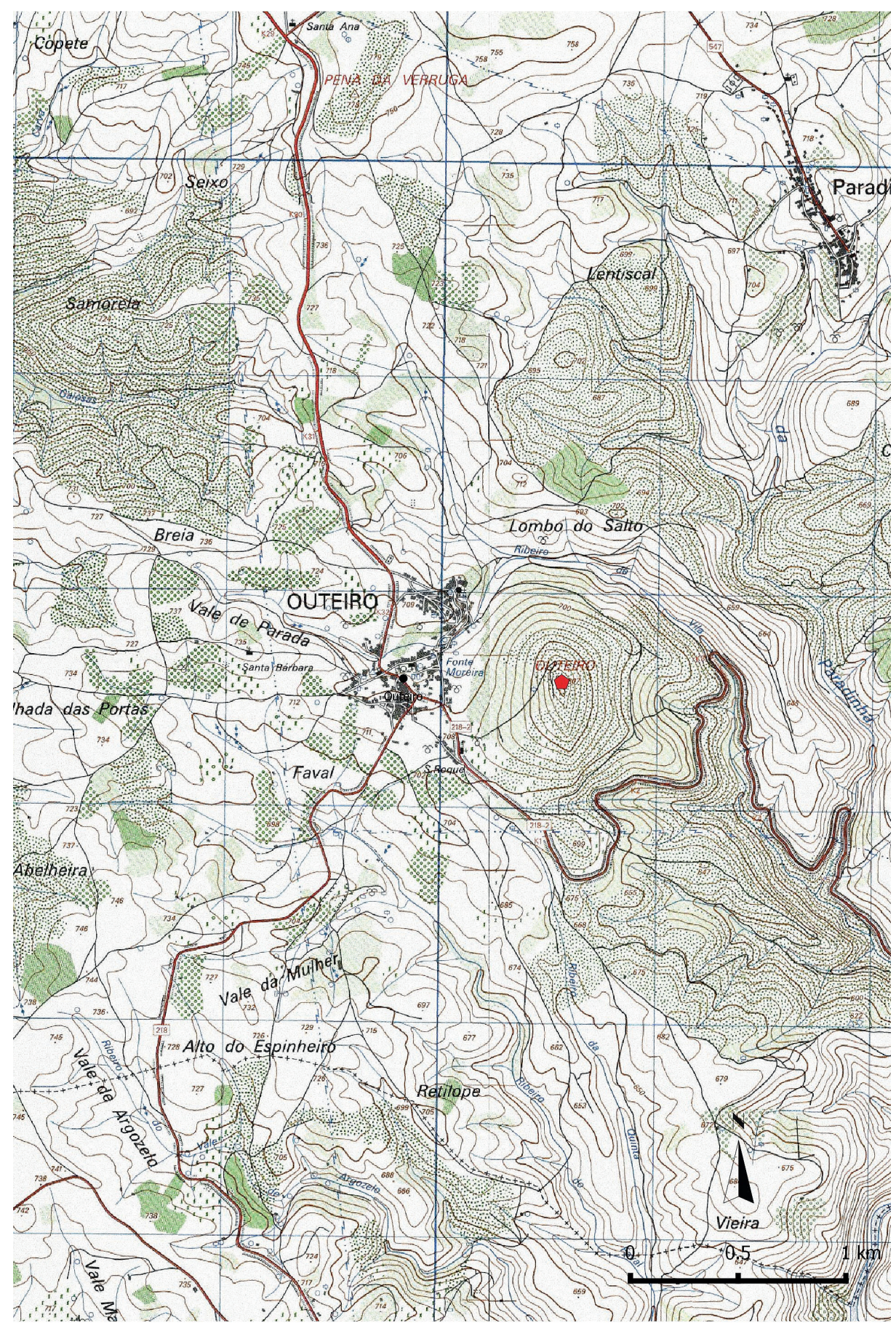

Mapa 1. Castelo de Outeiro assinalado na Carta Militar.

Fonte: Carta Militar de Portugal. Parada (Bragança), 1996 

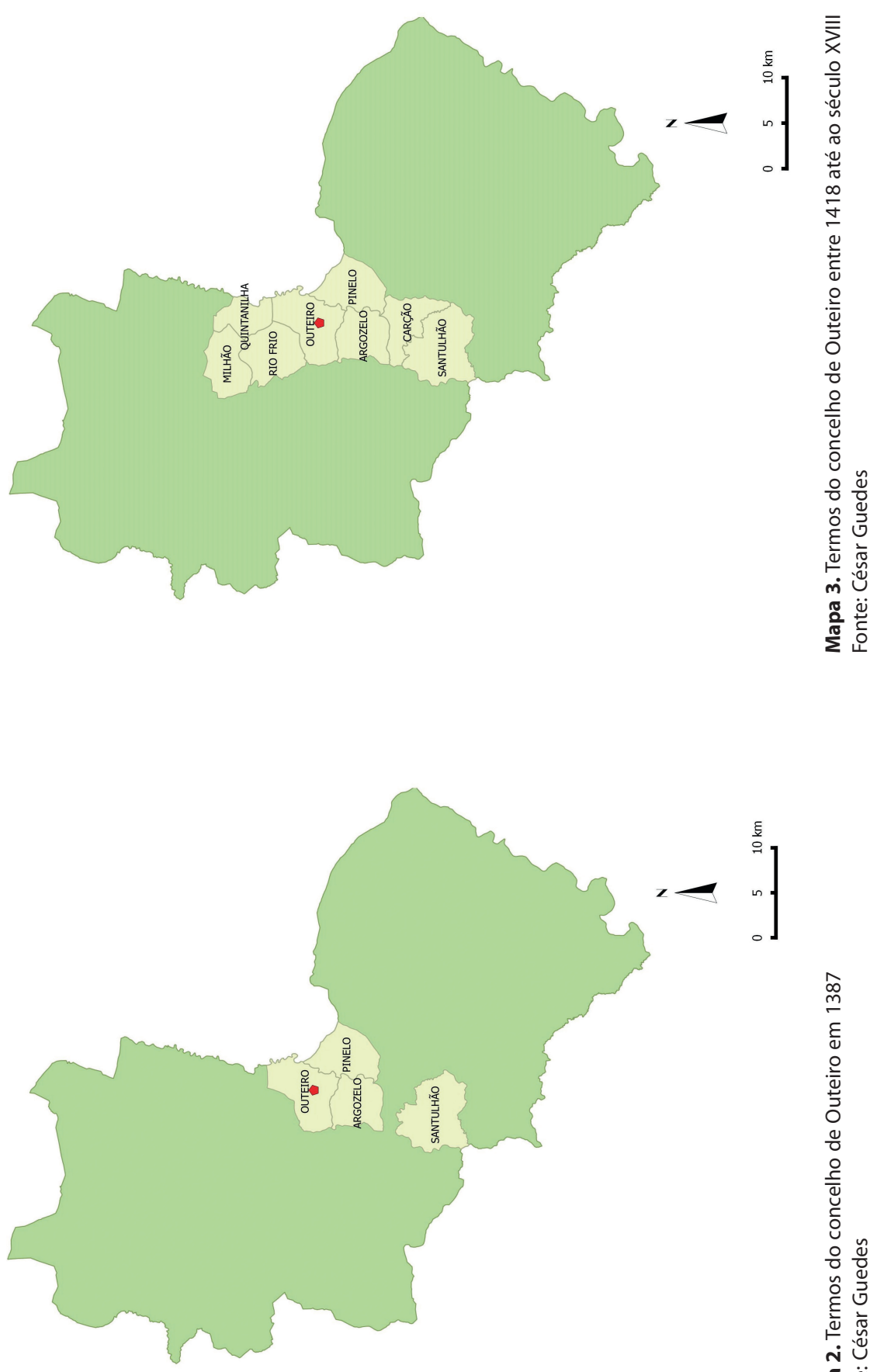

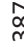

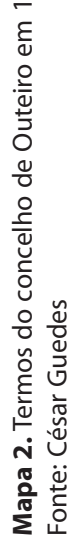



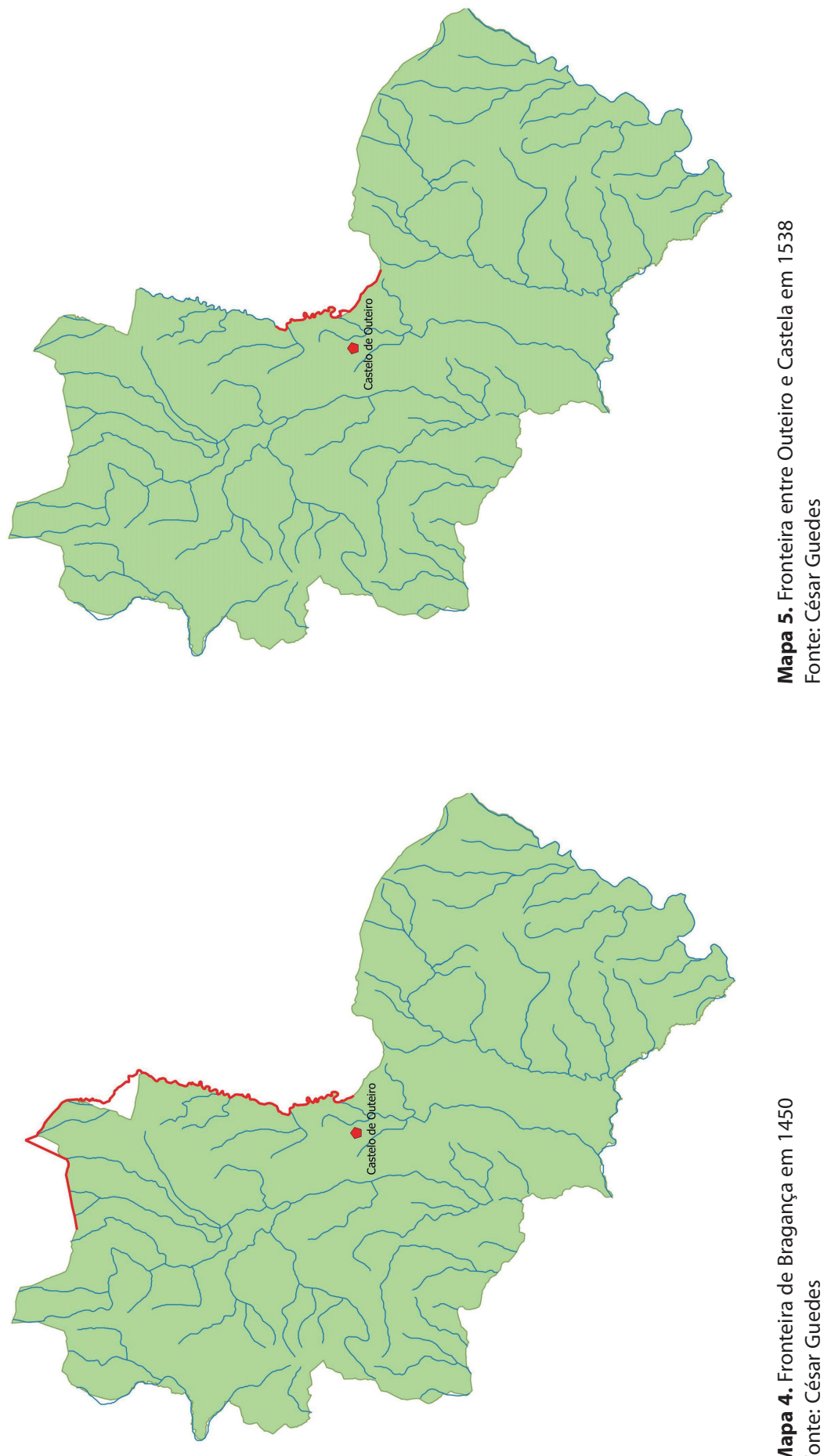

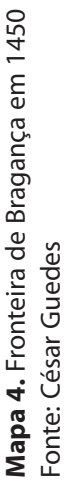




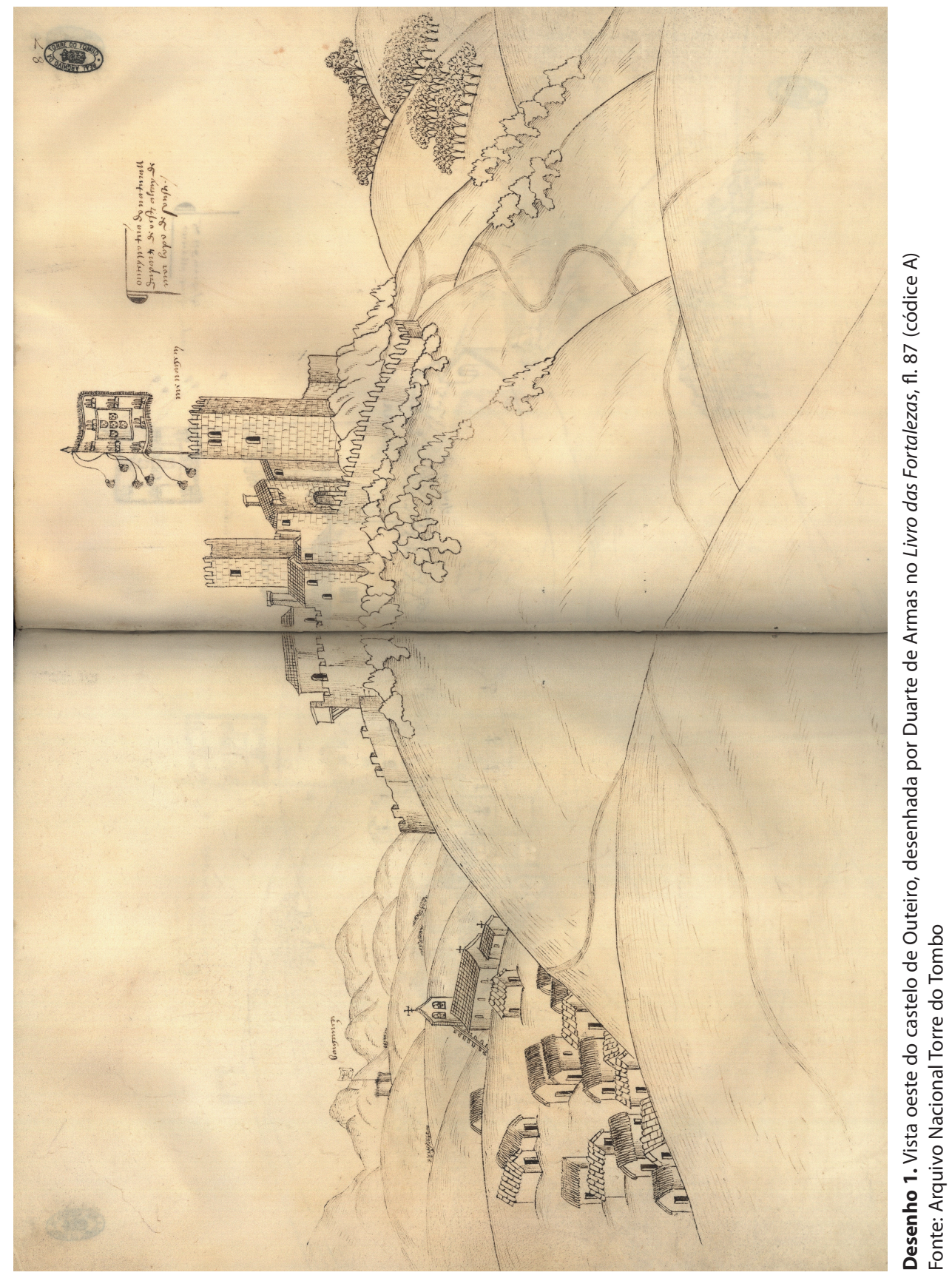




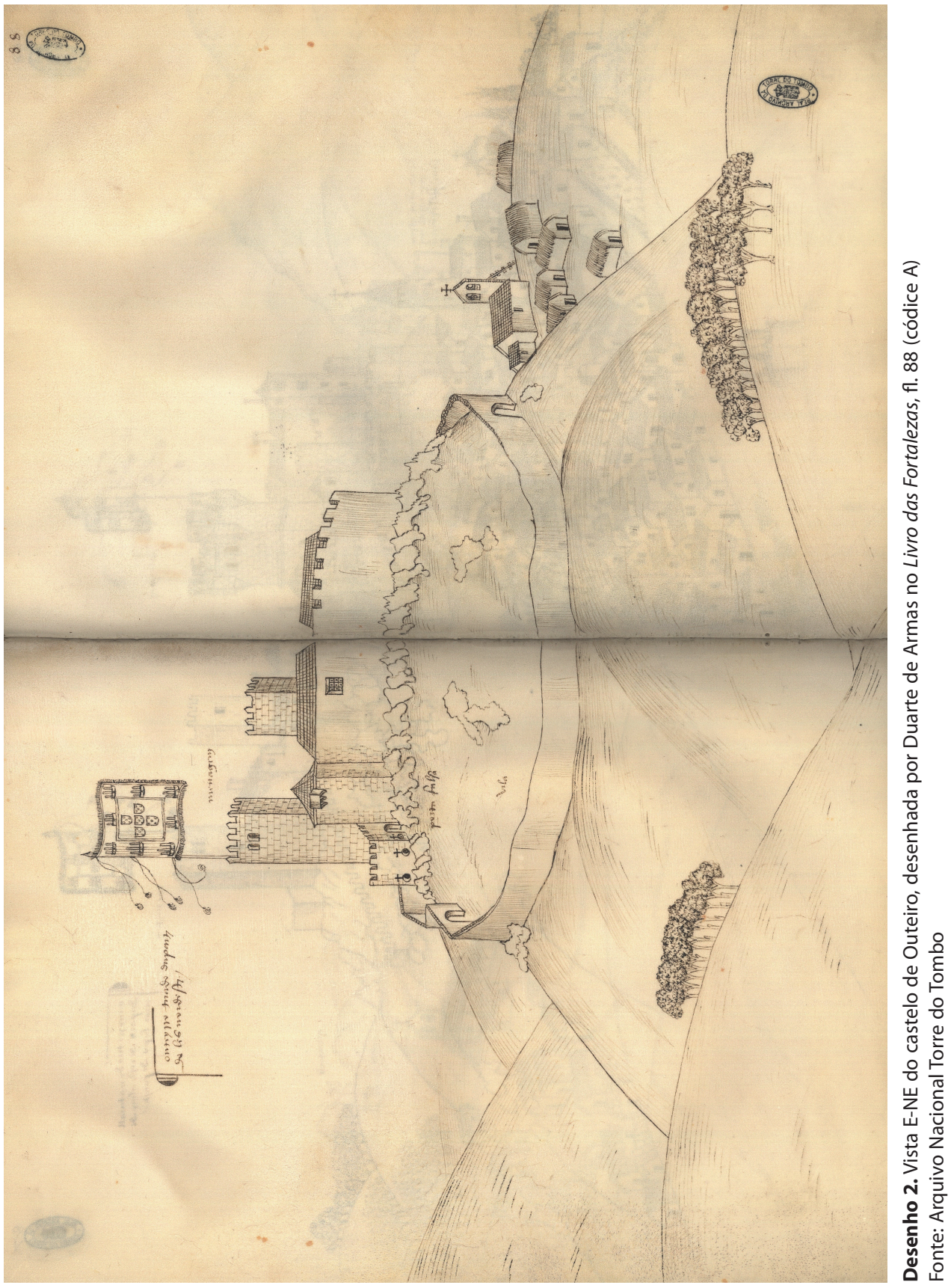




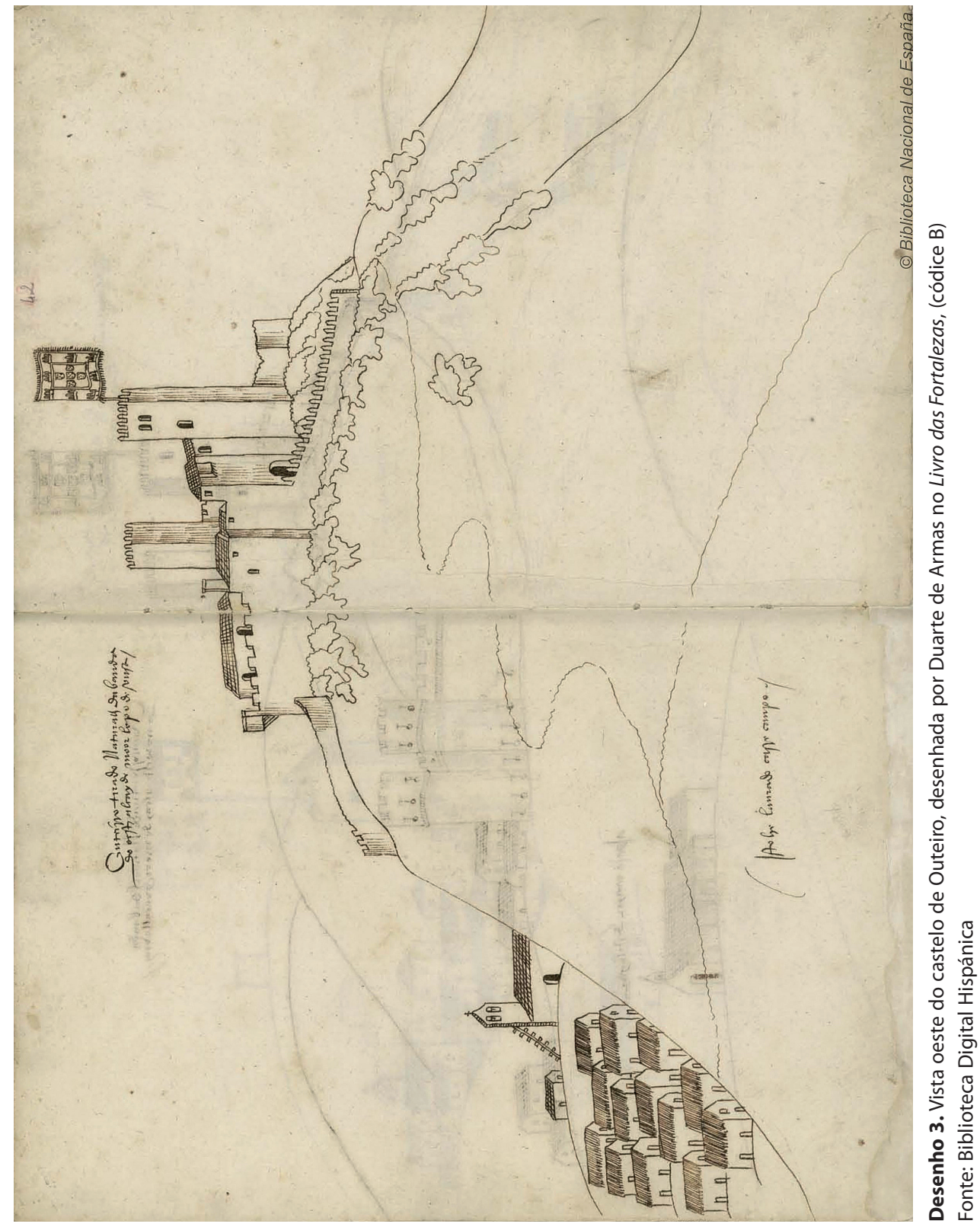


MAPAS, DESENHOS E PLANTAS

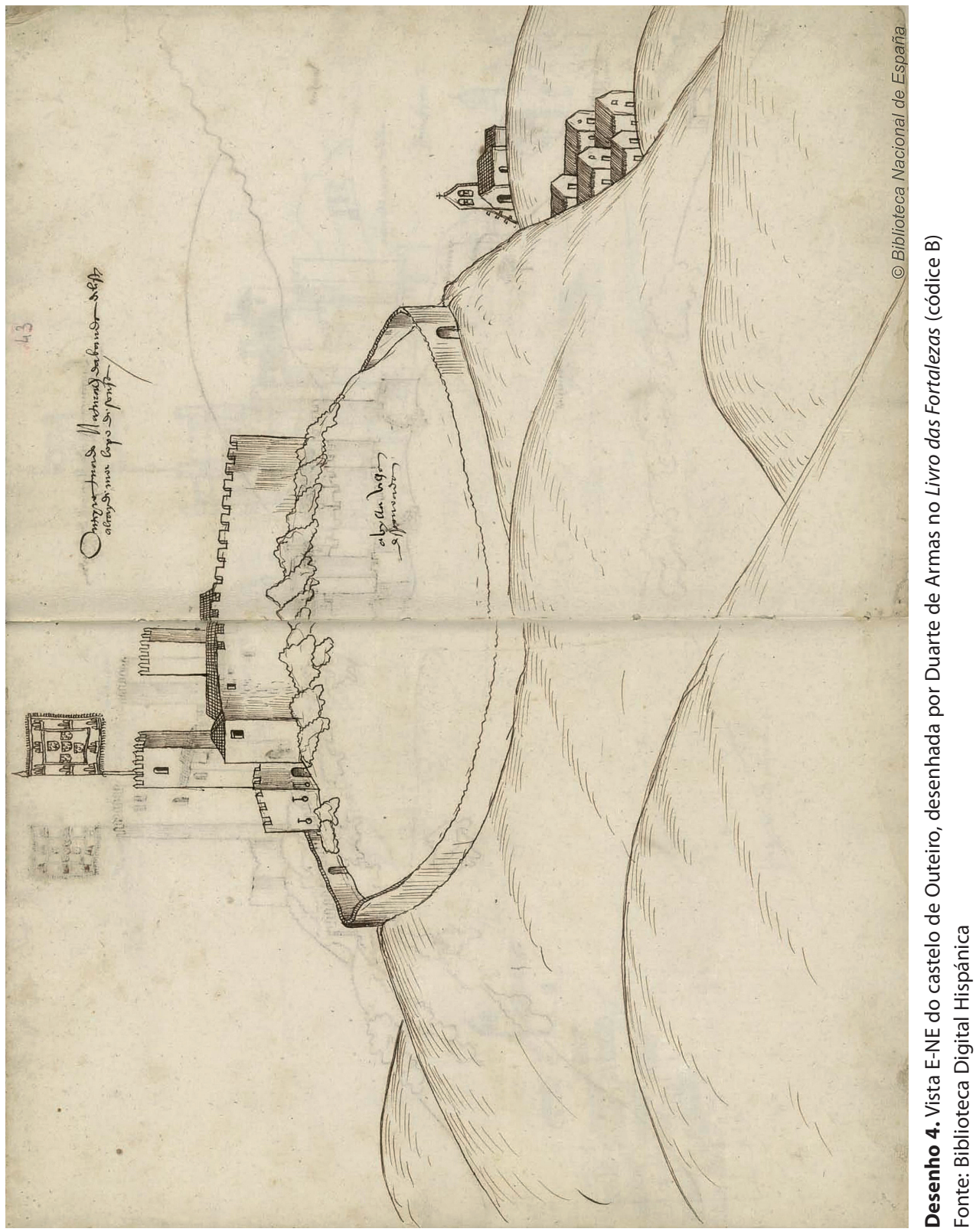




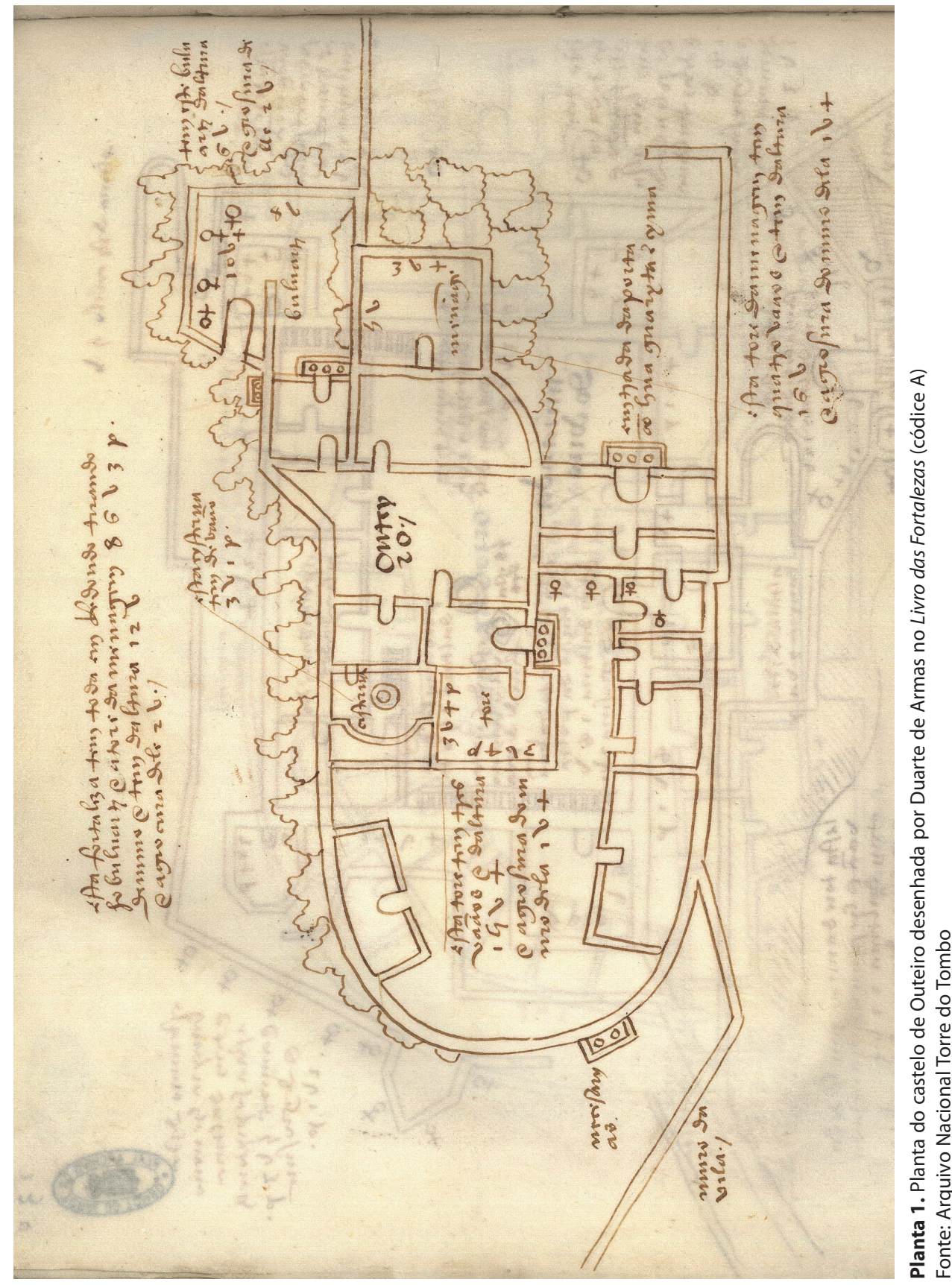



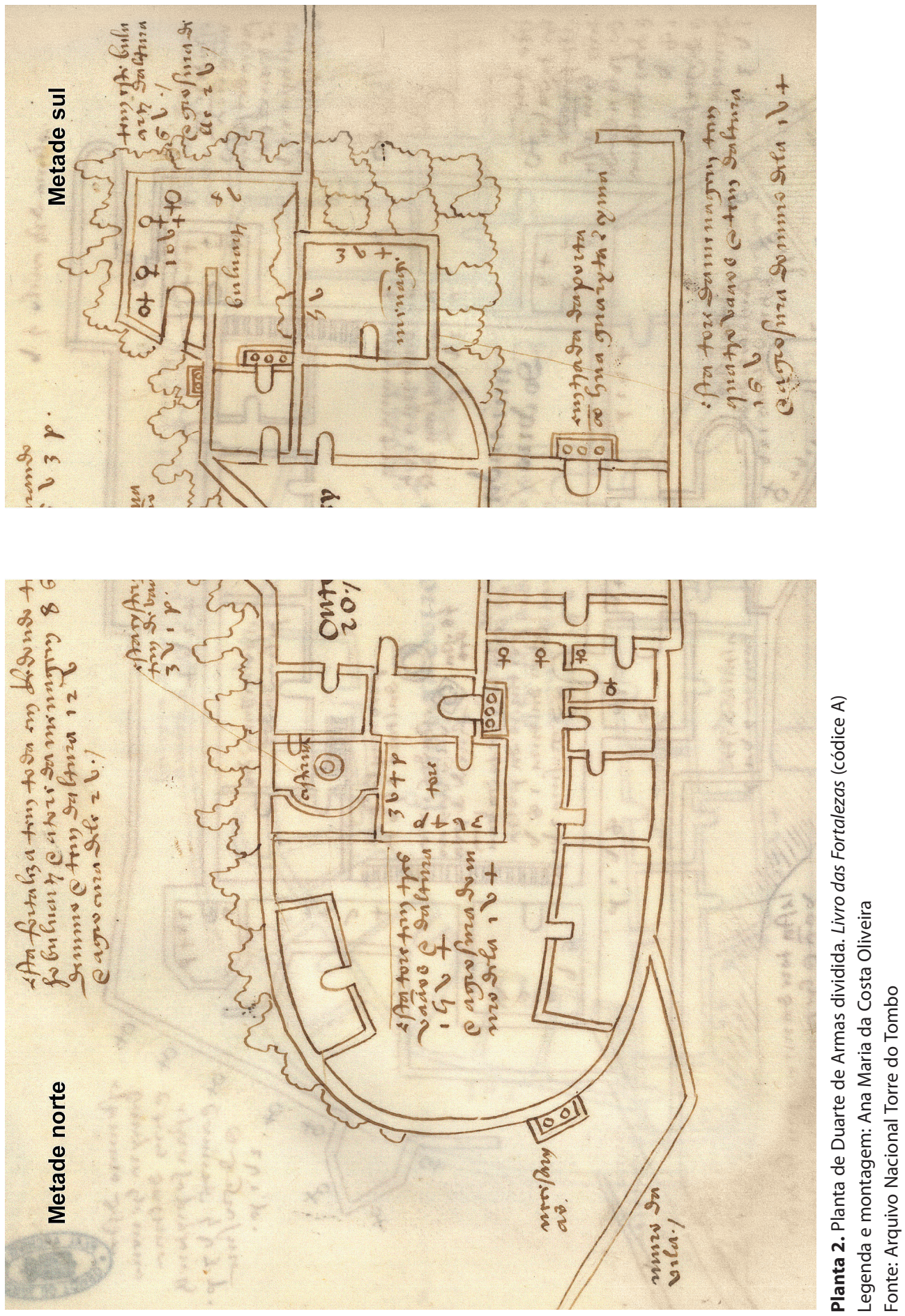


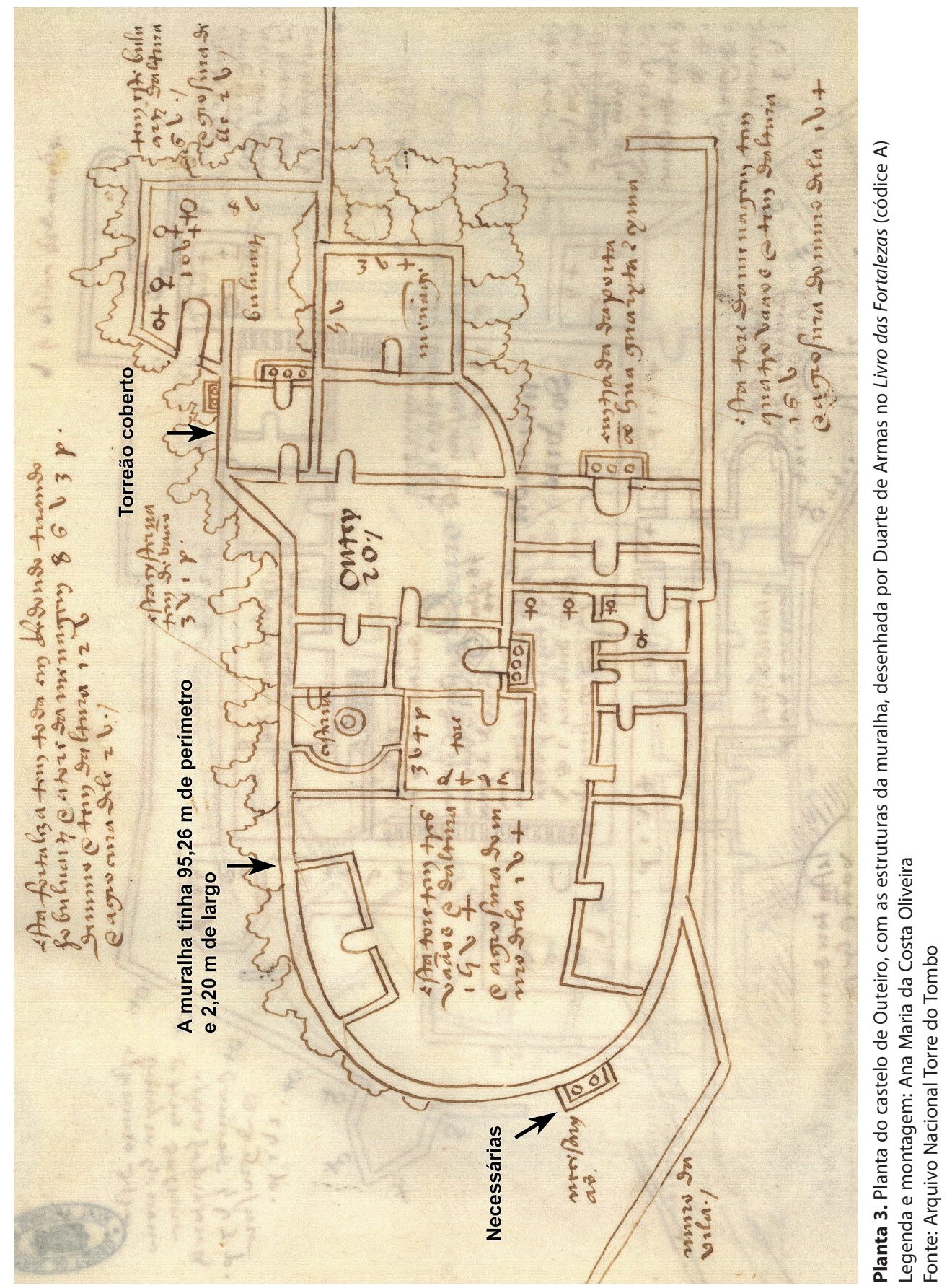




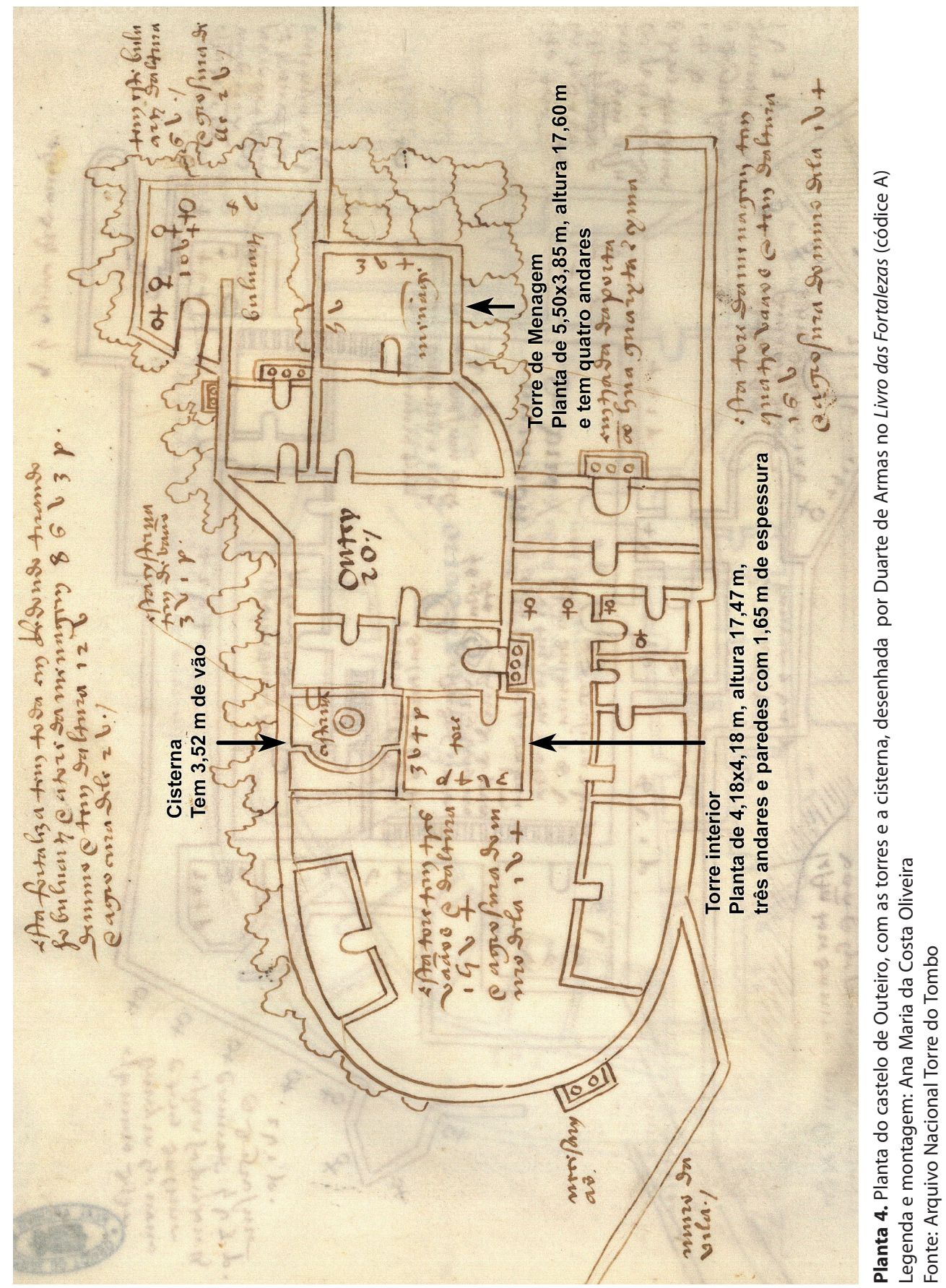




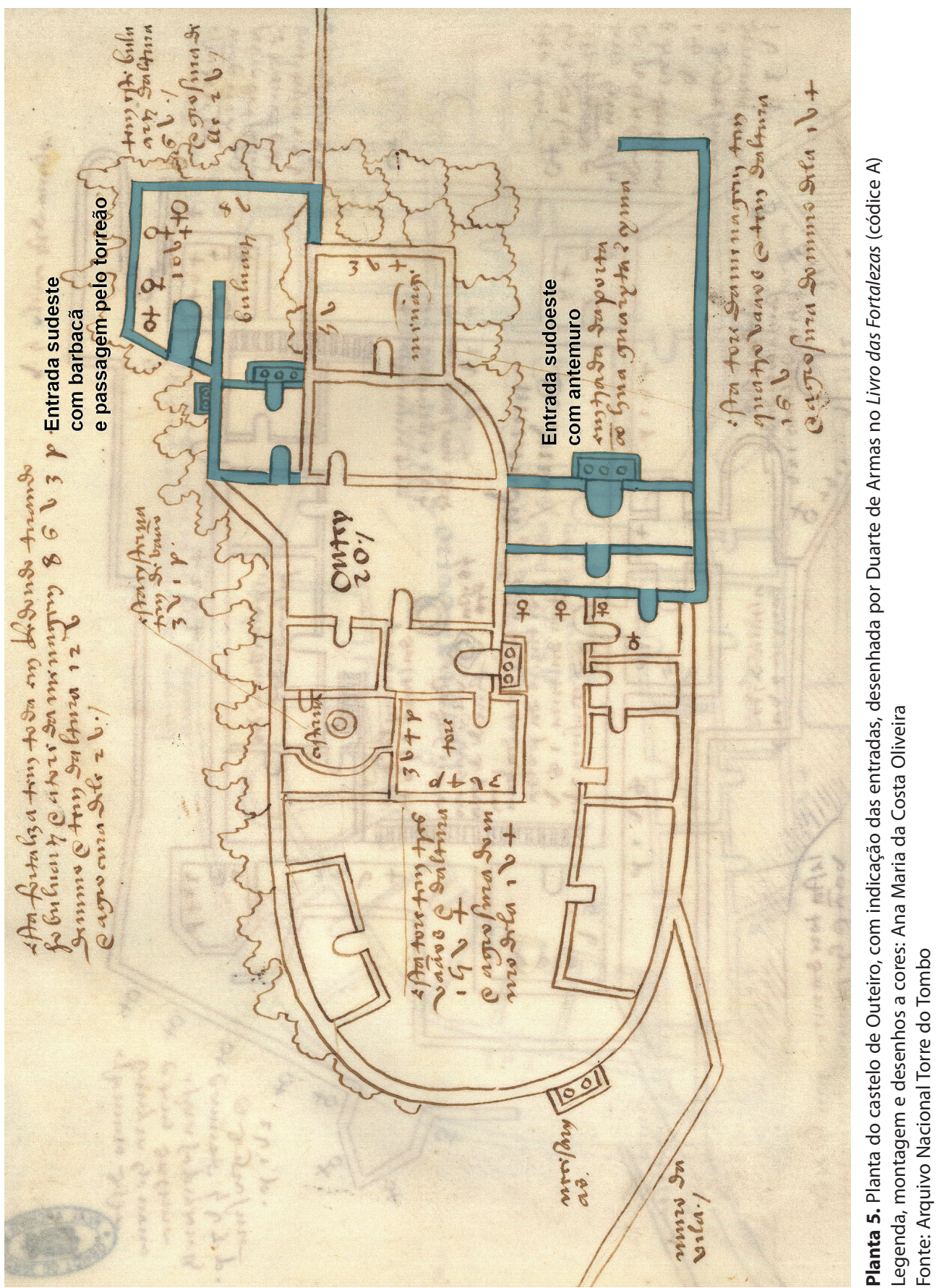




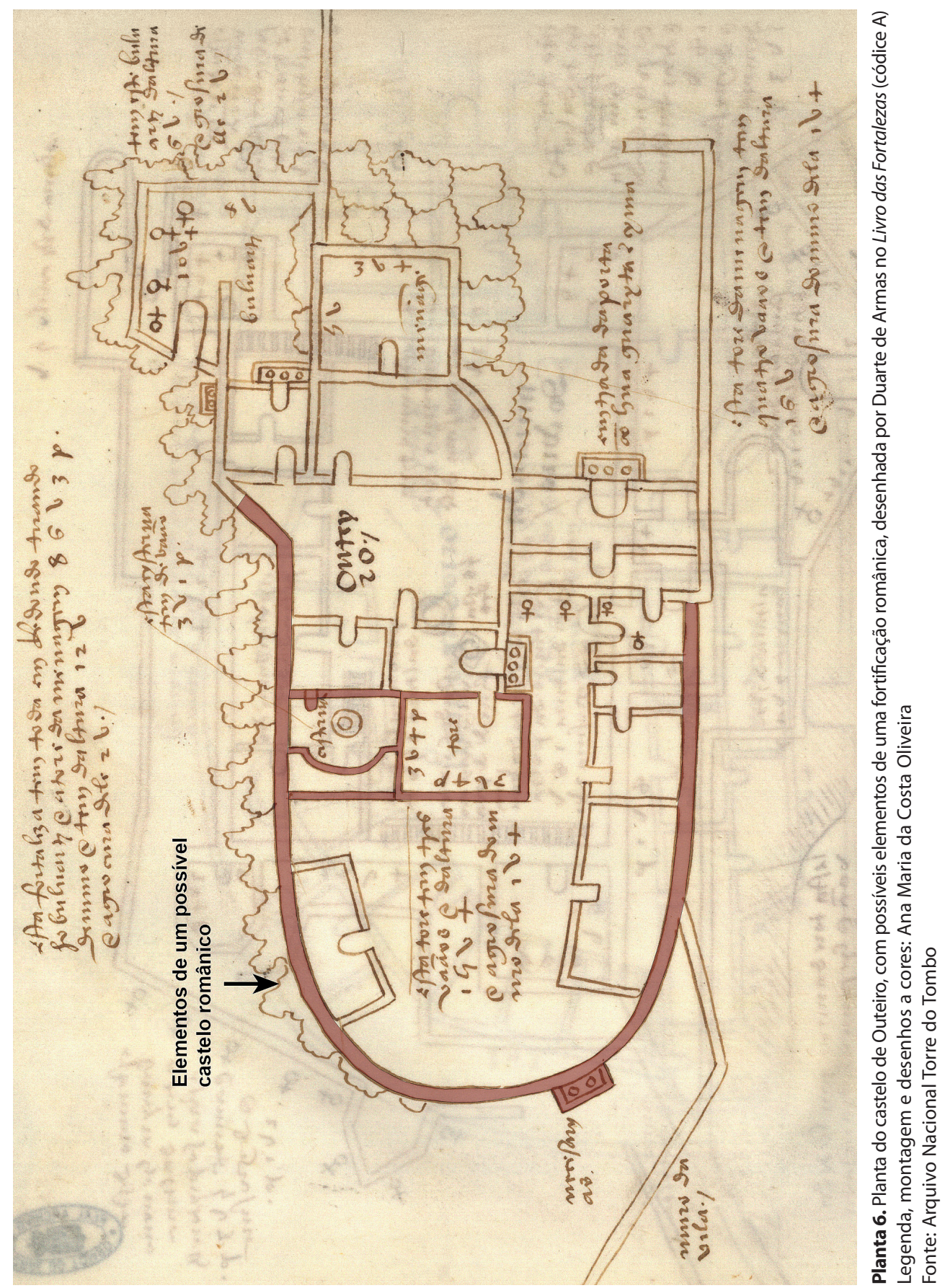




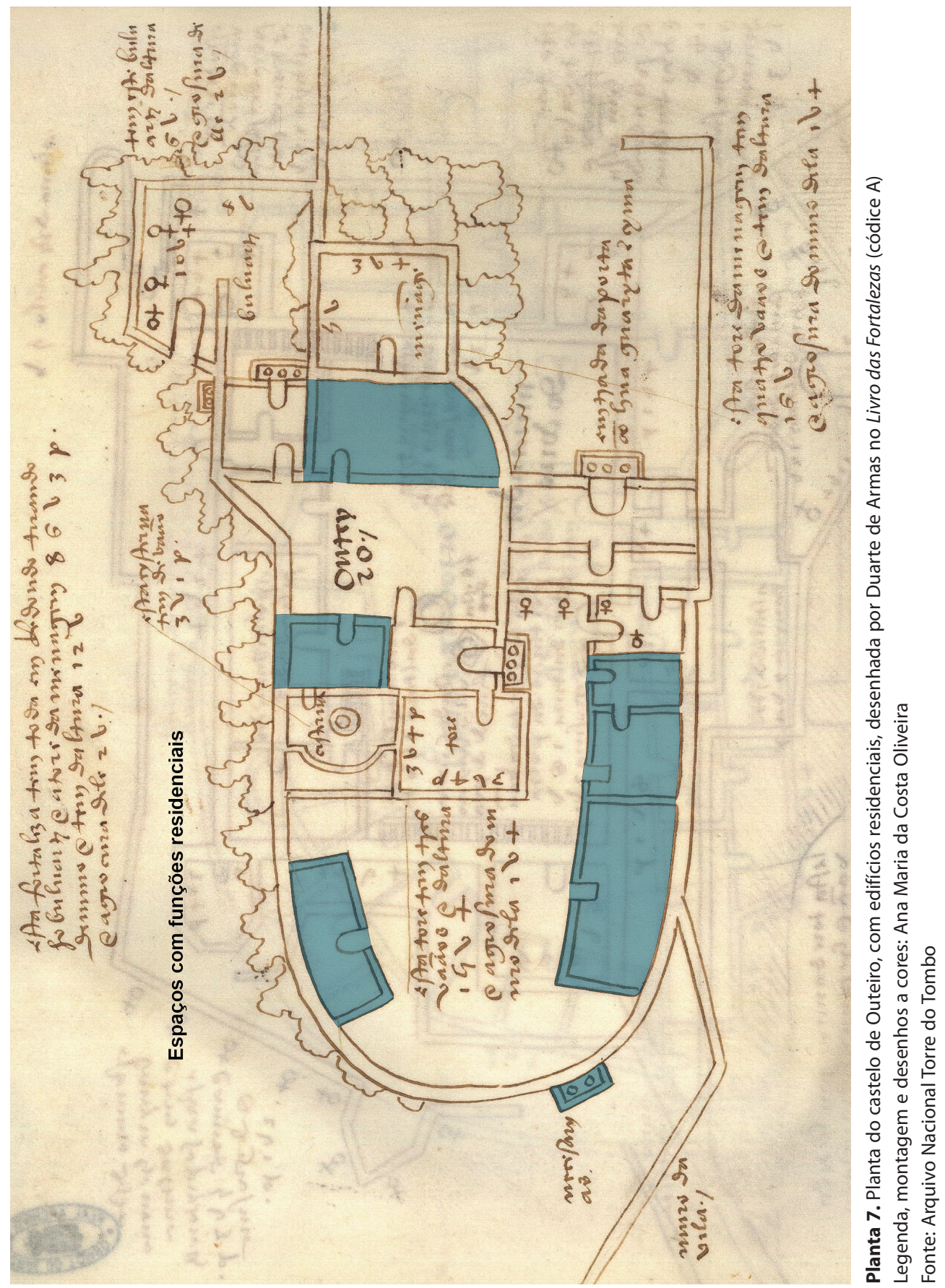




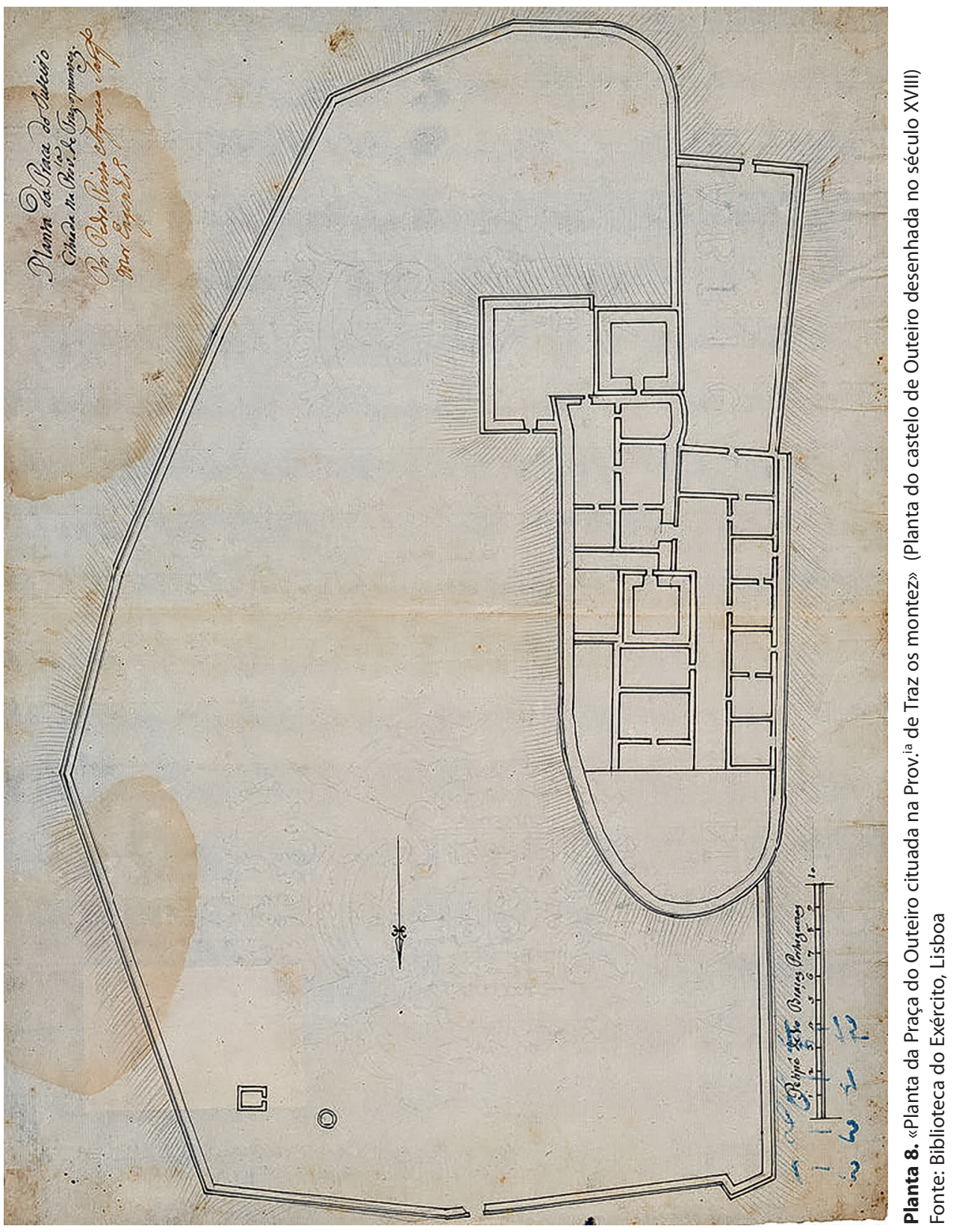




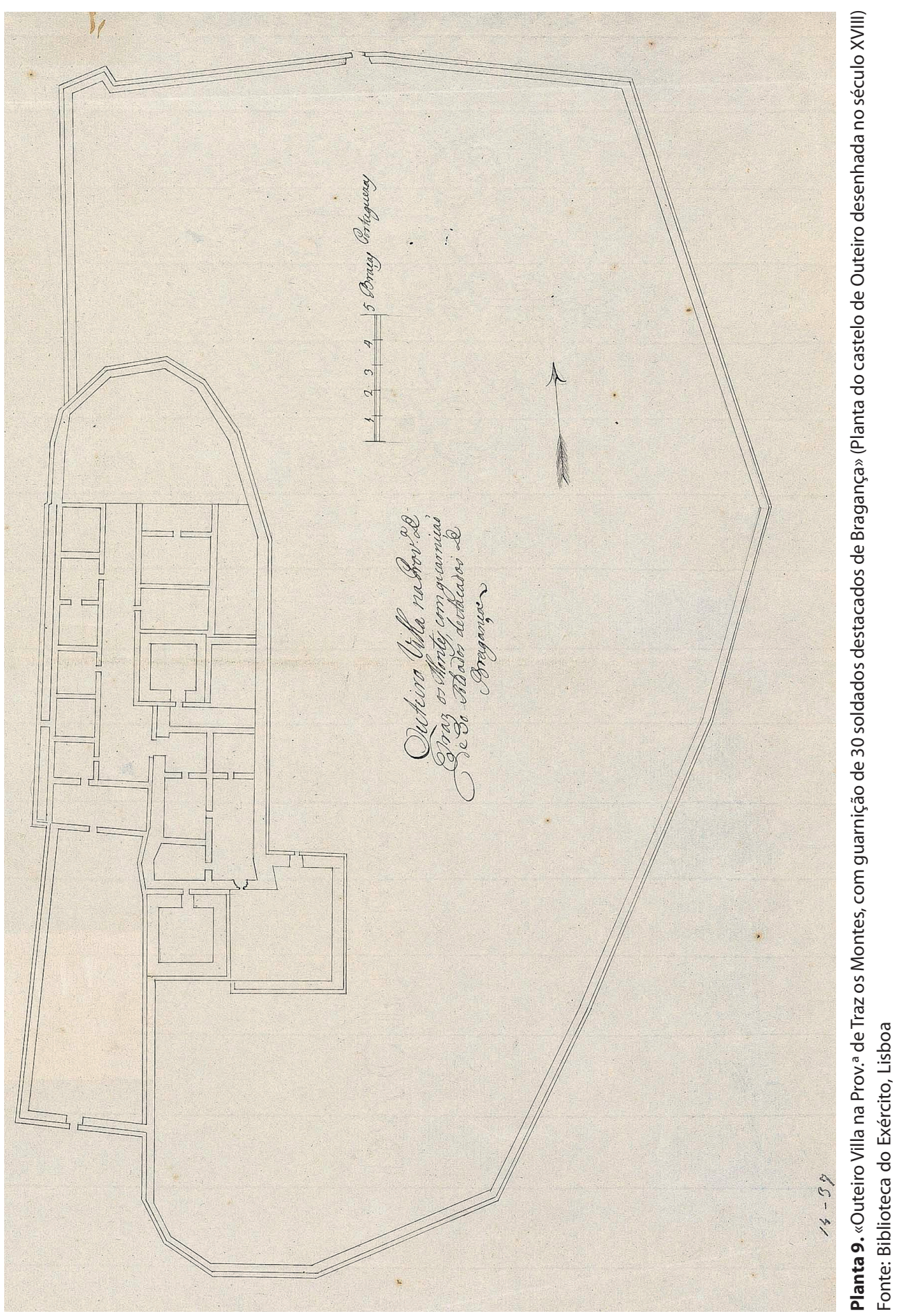




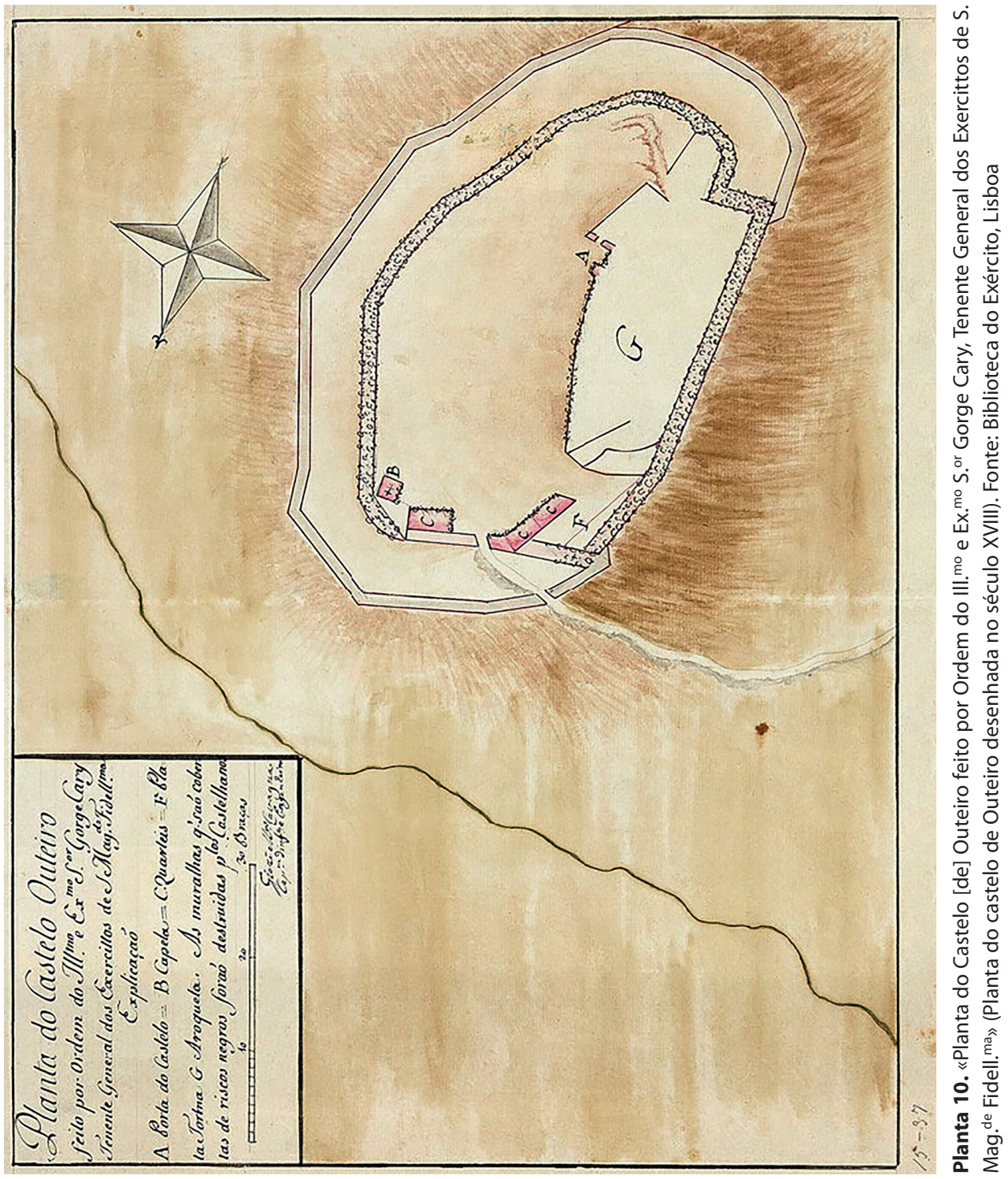




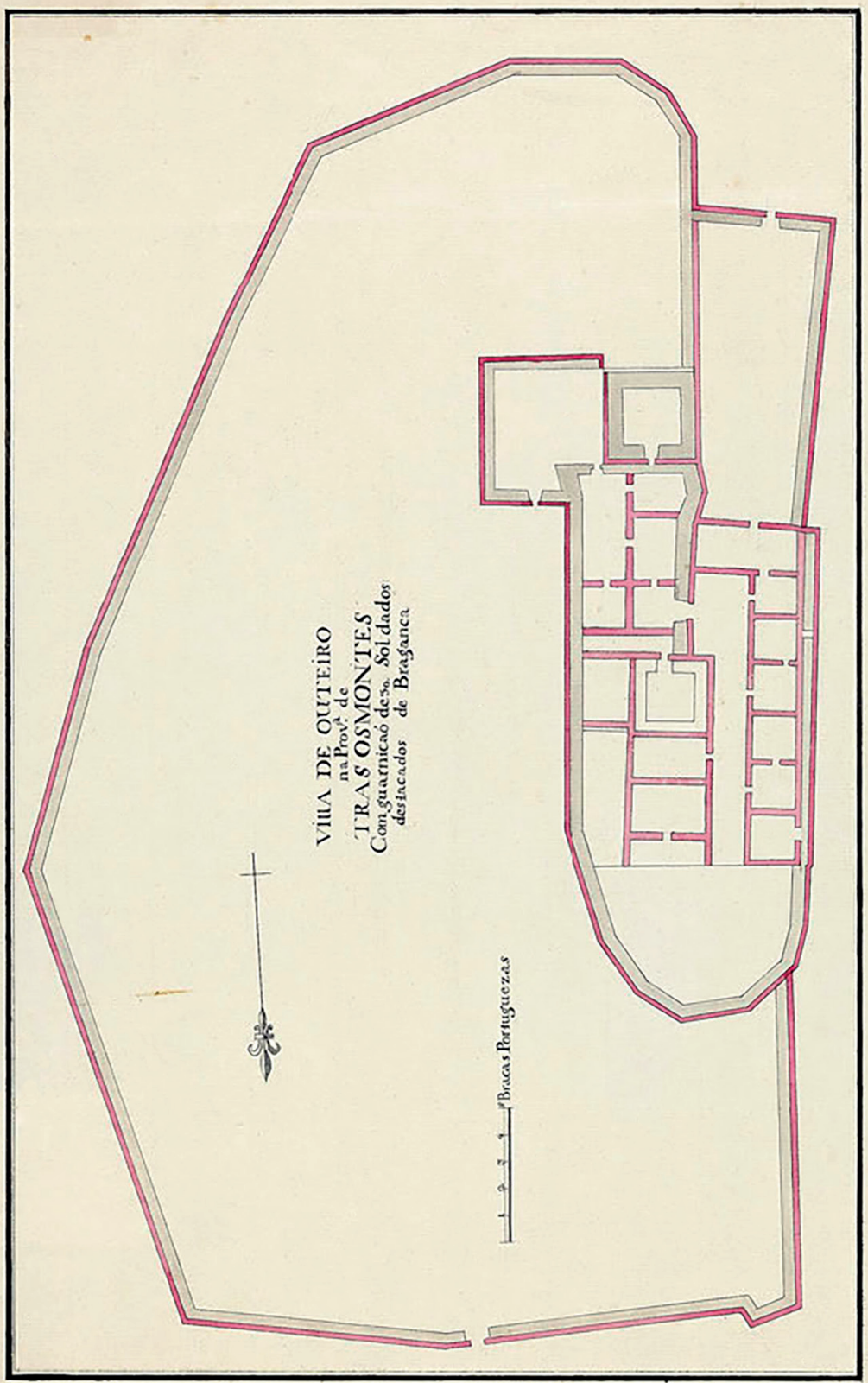




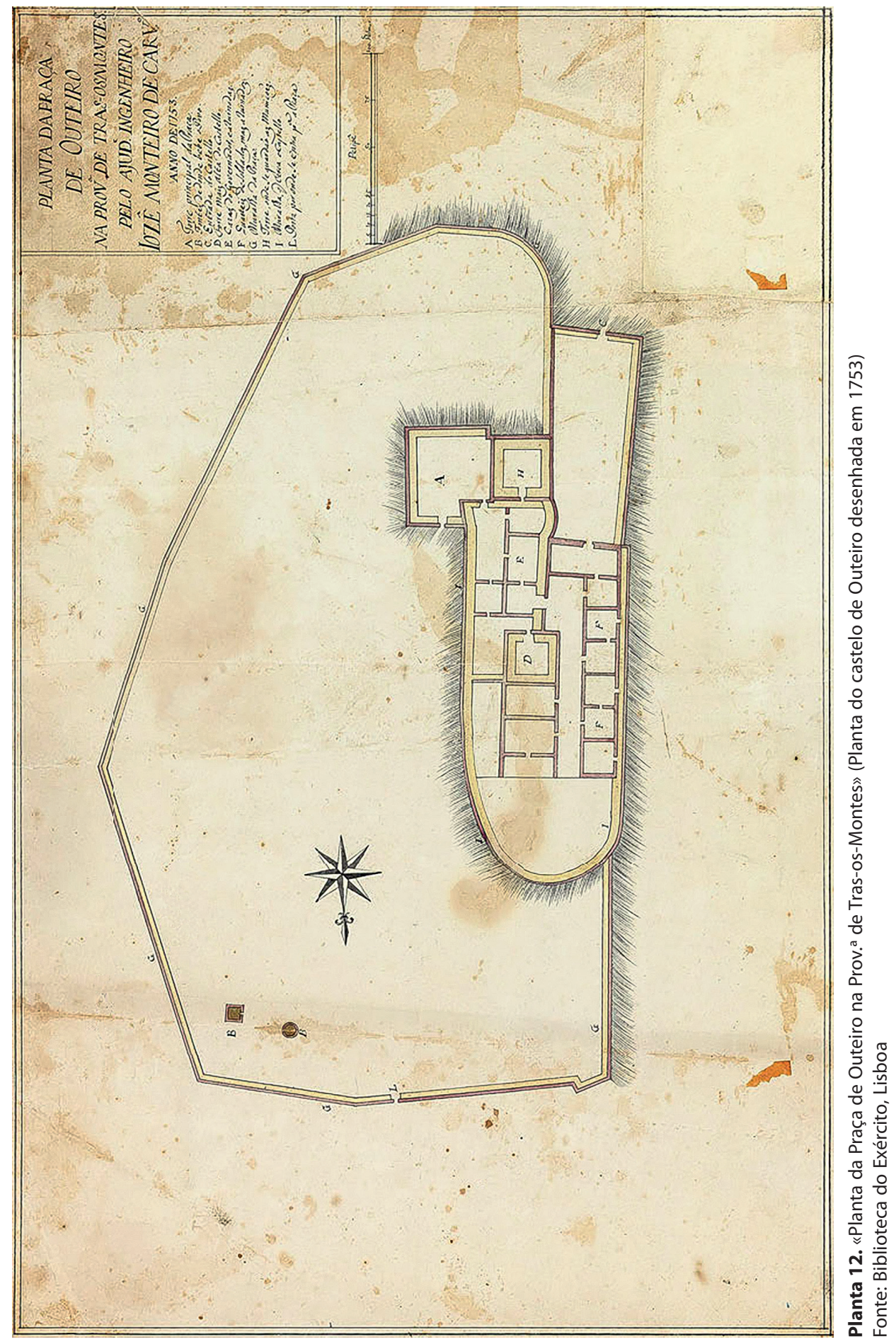




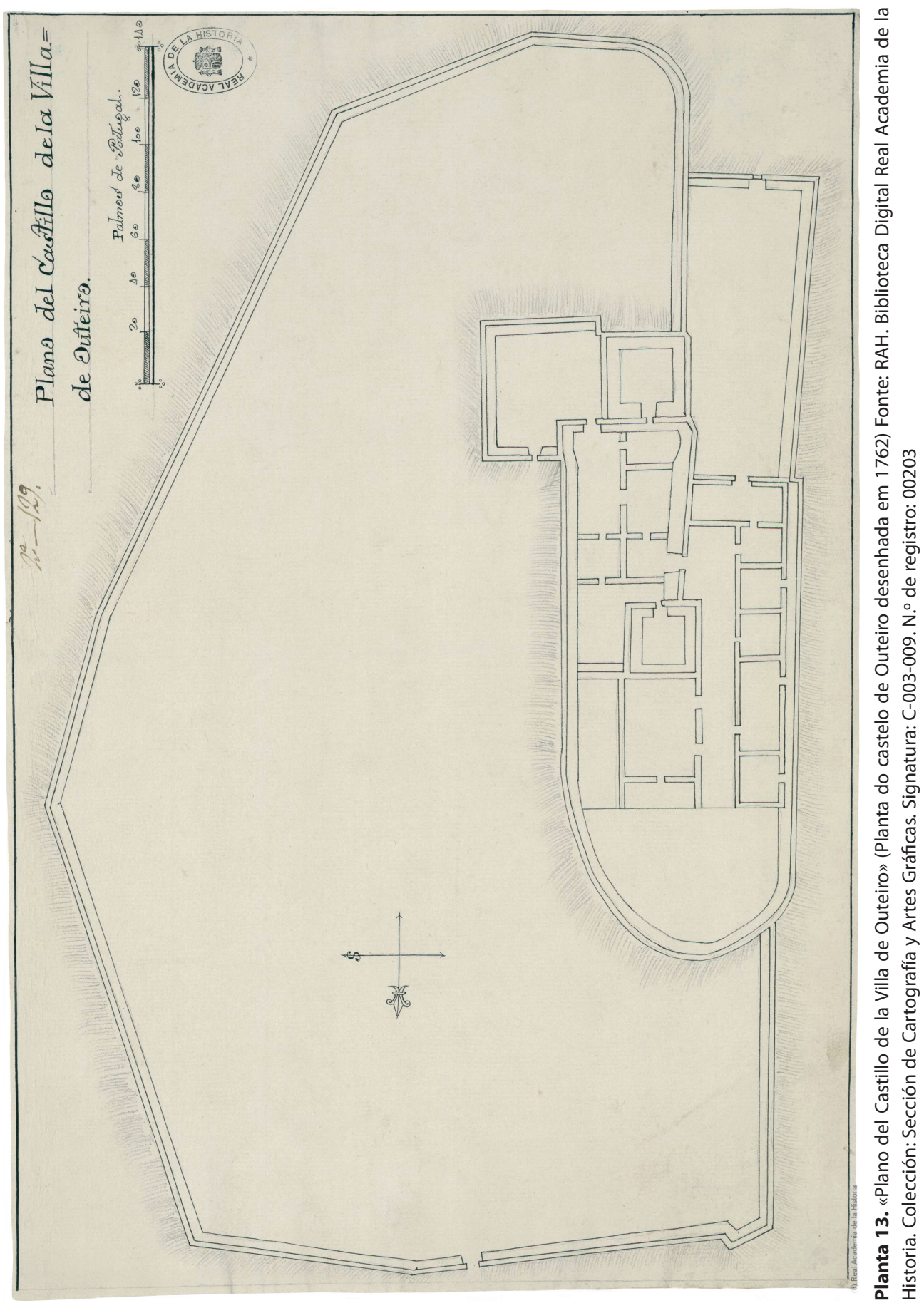



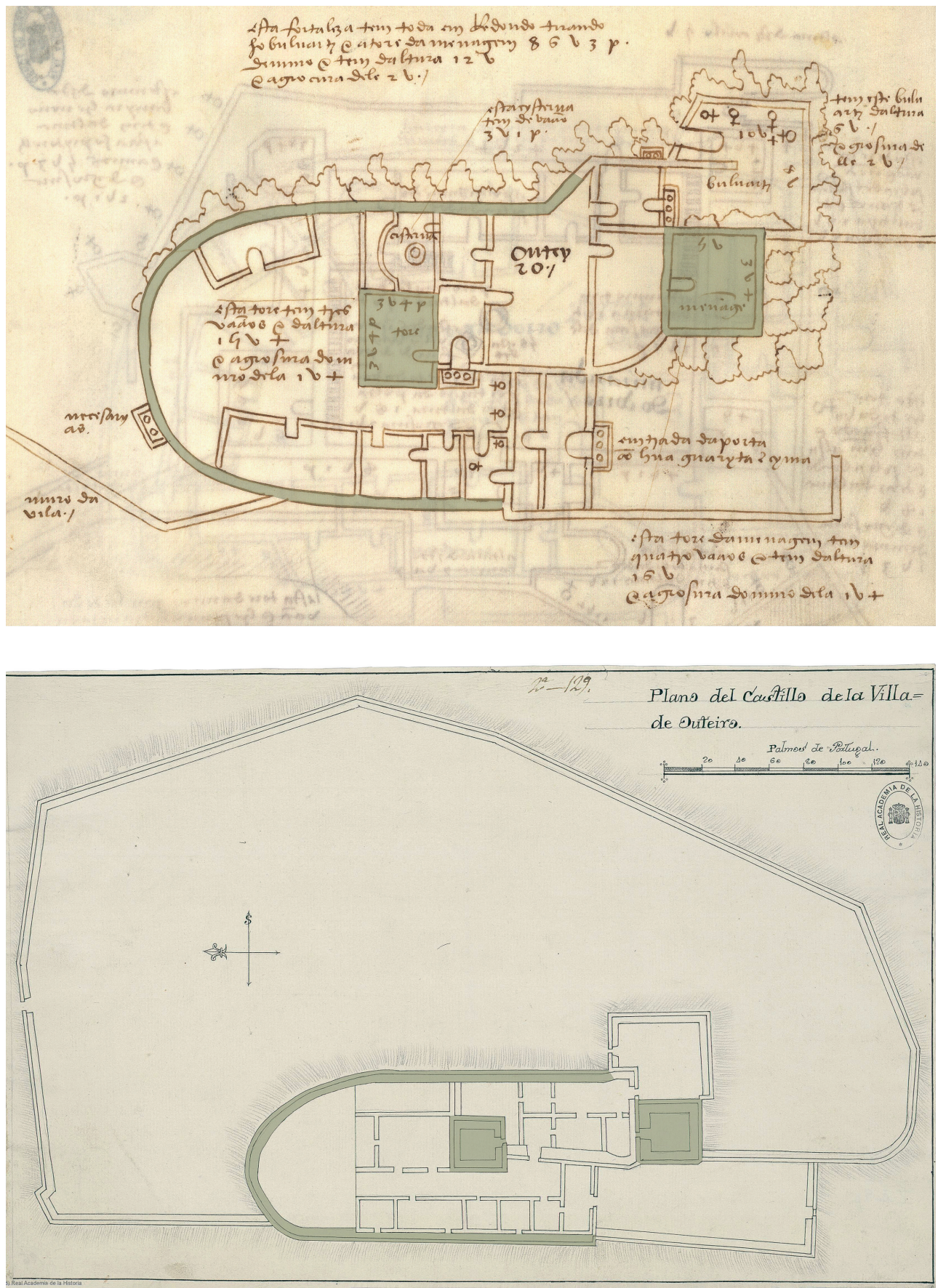

Planta 14. Plantas do castelo de Outeiro. Correspondências entre o desenho de Duarte de Armas e a planta de 1762 Legenda, montagem e desenhos a cores: Ana Maria da Costa Oliveira Fonte: Arquivo Nacional Torre do Tombo; Biblioteca Digital Real Academia de la Historia 

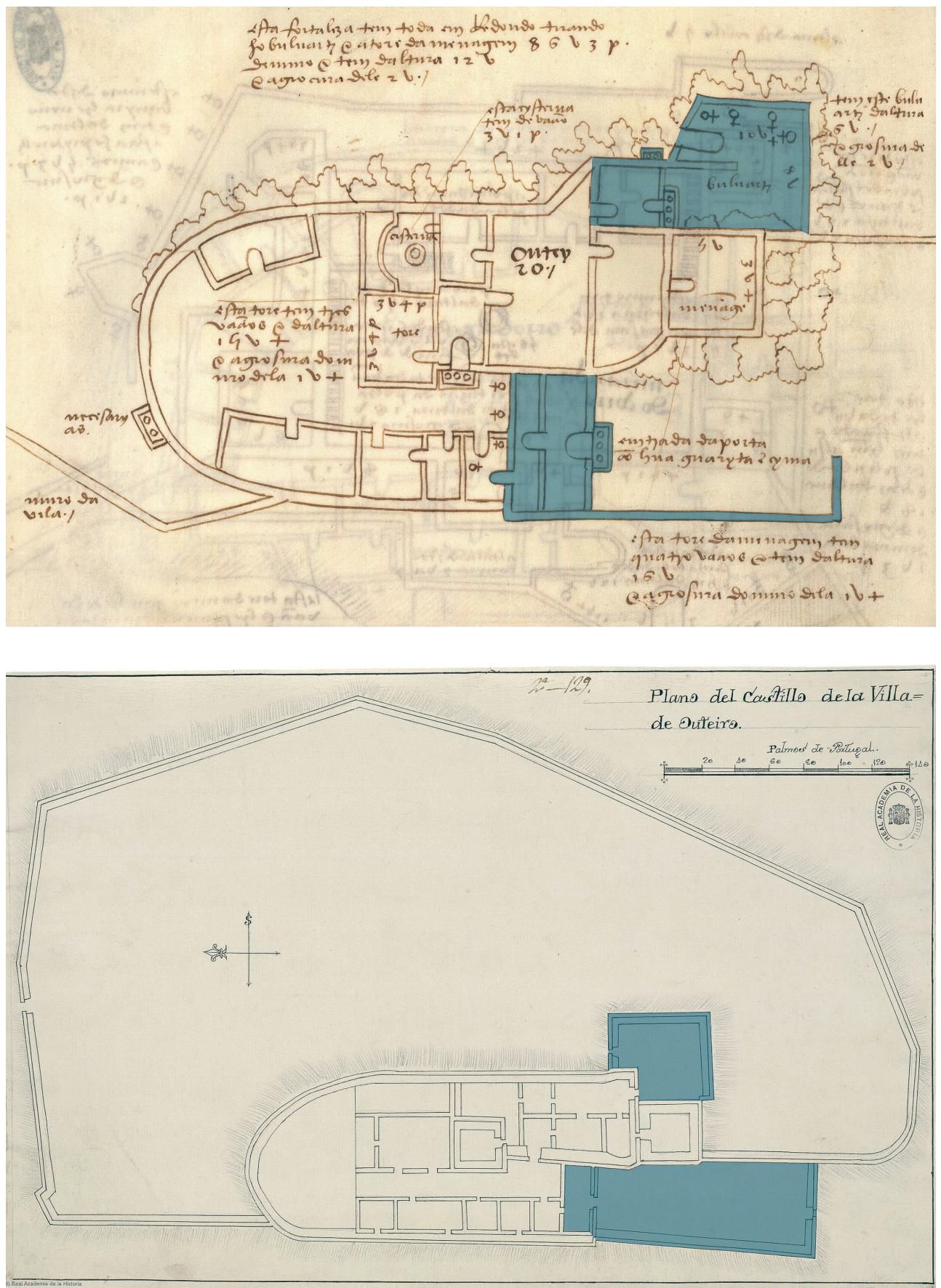

Planta 15. Plantas do castelo de Outeiro com desenhos de Duarte de Armas e de 1762. Alterações nas entradas Legenda, montagem e desenhos a cores: Ana Maria da Costa Oliveira Fonte: Arquivo Nacional Torre do Tombo; Biblioteca Digital Real Academia de la Historia 

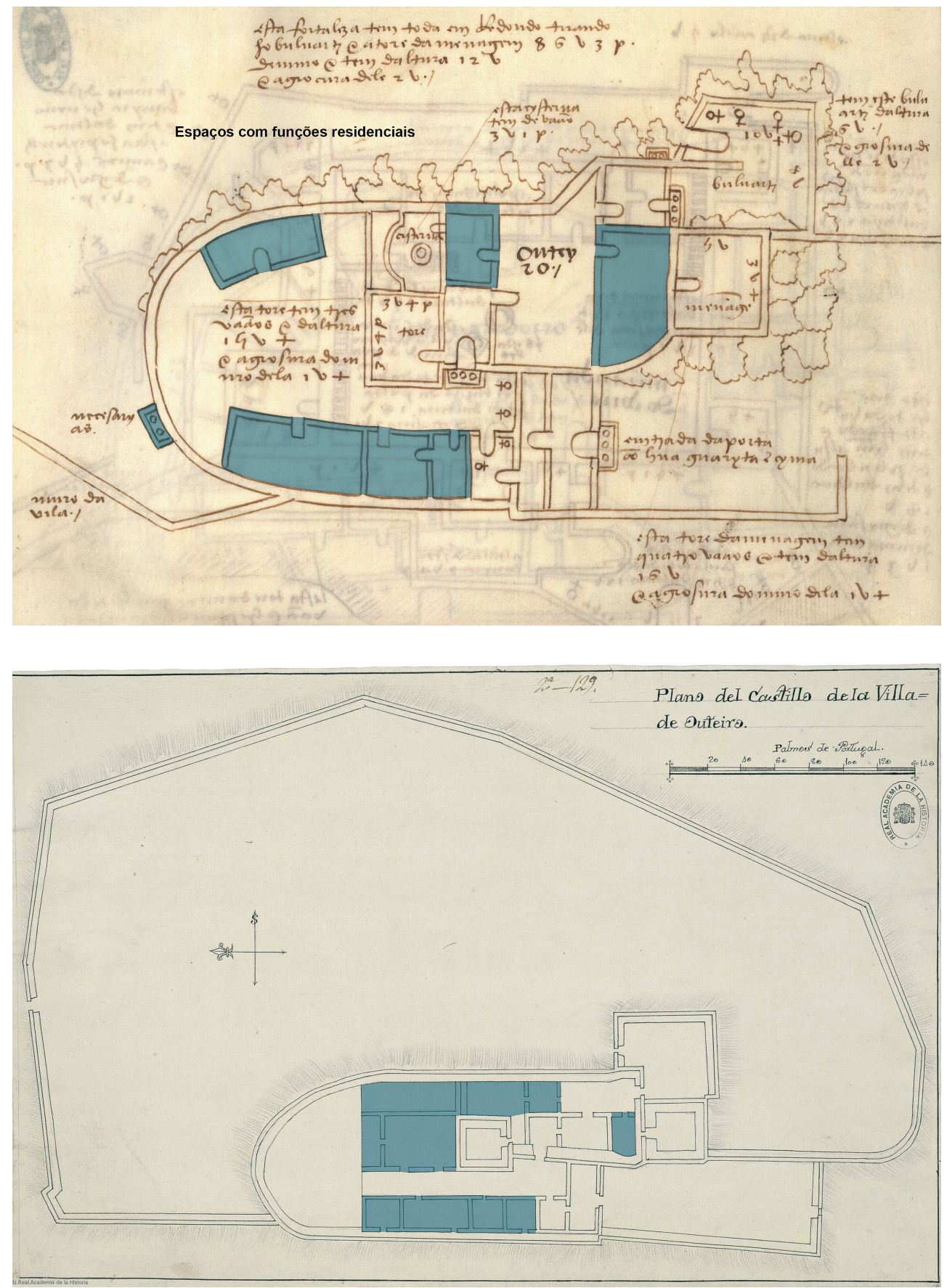

Planta 16. Plantas do castelo com desenhos de Duarte de Armas e de 1762. Alterações nos edifícios de habitação Legenda, montagem e desenhos a cores: Ana Maria da Costa Oliveira Fonte: Arquivo Nacional Torre do Tombo; Biblioteca Digital Real Academia de la Historia 

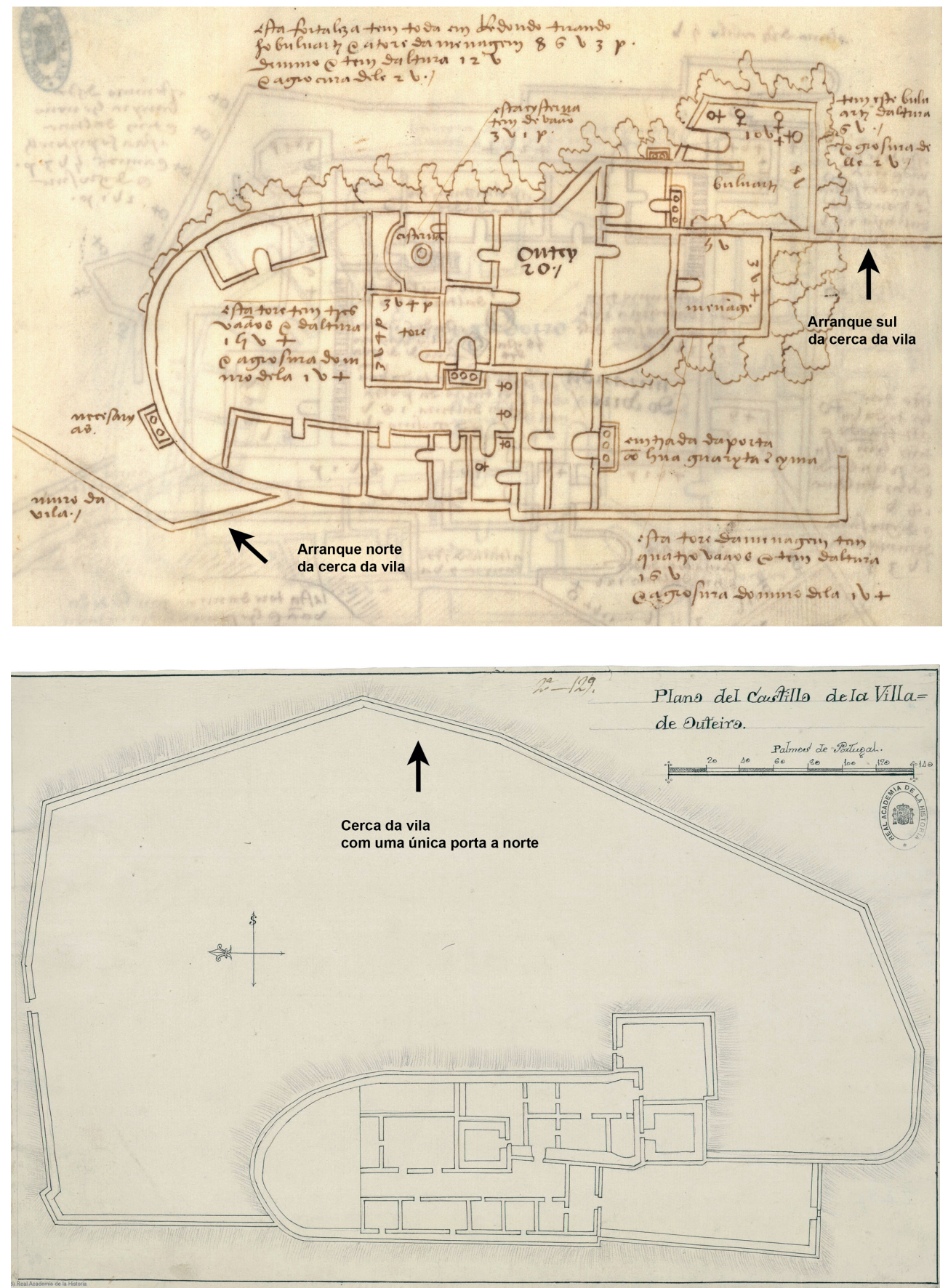

Planta 17. Plantas do castelo de Outeiro com desenhos de Duarte de Armas e de 1762. As alterações na cerca da vila Legenda e montagem: Ana Maria da Costa Oliveira

Fonte: Arquivo Nacional Torre do Tombo; Biblioteca Digital Real Academia de la Historia 
MAPAS, DESENHOS E PLANTAS

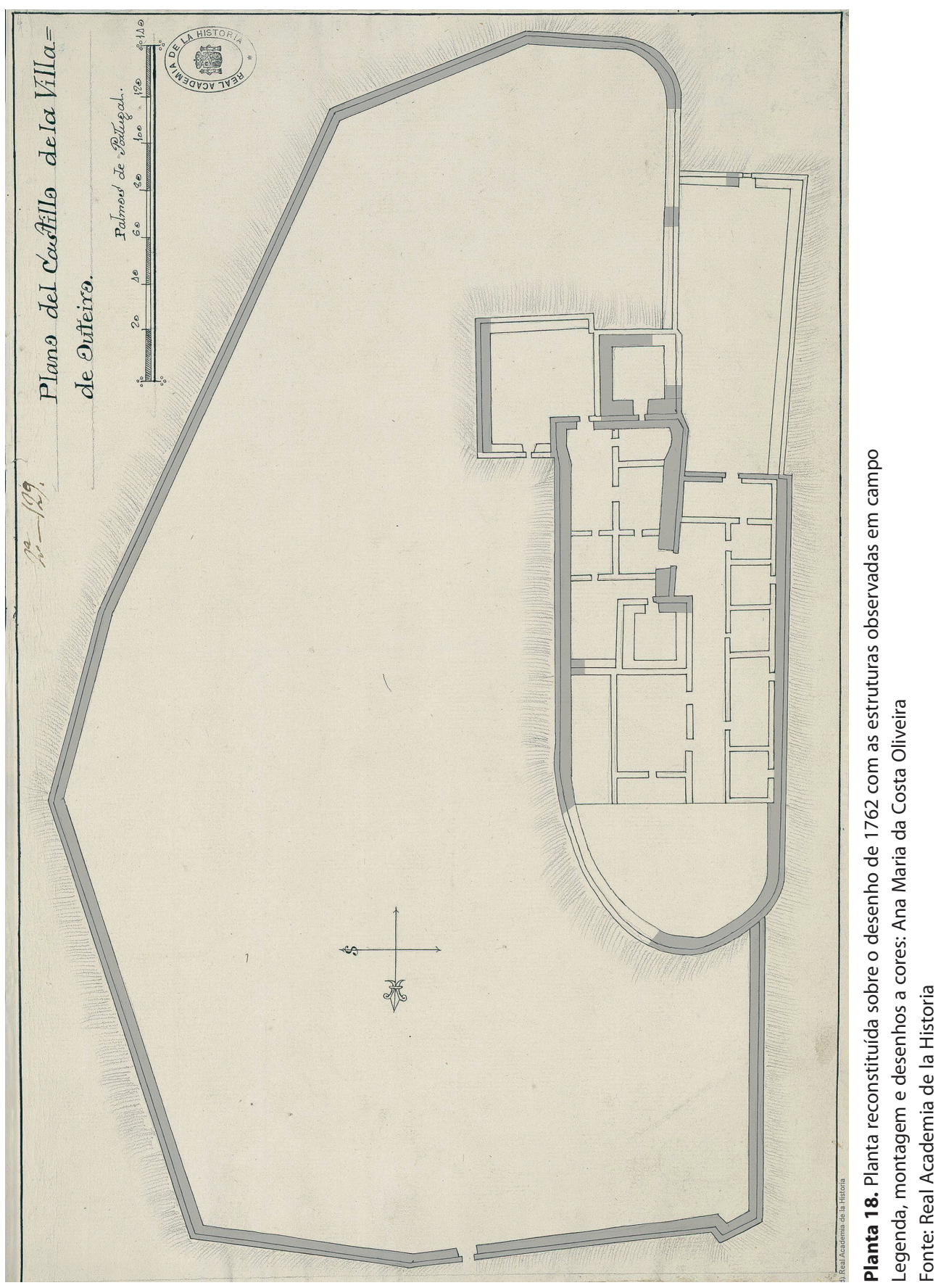





\section{CASTELO DE OUTEIRO UM MARCO NA FRONTEIRA TRANSMONTANA}

\section{ANA MARIA OLIVEIRA}

